$$
\begin{aligned}
& \text { UNIVERSIDADE DE SÃO PAULO } \\
& \text { INSTITUTO DE GEOCIENNCIAS }
\end{aligned}
$$

\title{
GEOPROCESSAMENTO E SENSORIAMENTO REMOTO COMO APOIO AO PLANEJAMENTO TERRITORIAL DO MUNICÍPIO DE IPORANGA - SP
}

\author{
ALEXANDRE CARNIER NUNES DA SILVA
}

Orientador: Prof. Dr. Arlei Benedito Macedo

\author{
DISSERTAÇÃO DE MESTRADO
}

COMISSÃO JULGADORA

Nome

Assinatura

Presidente: $\quad$ Prof. Dr. Arlei Benedito Macedo

Examinadores: Profa. Dra. Paulina Setti Riedel

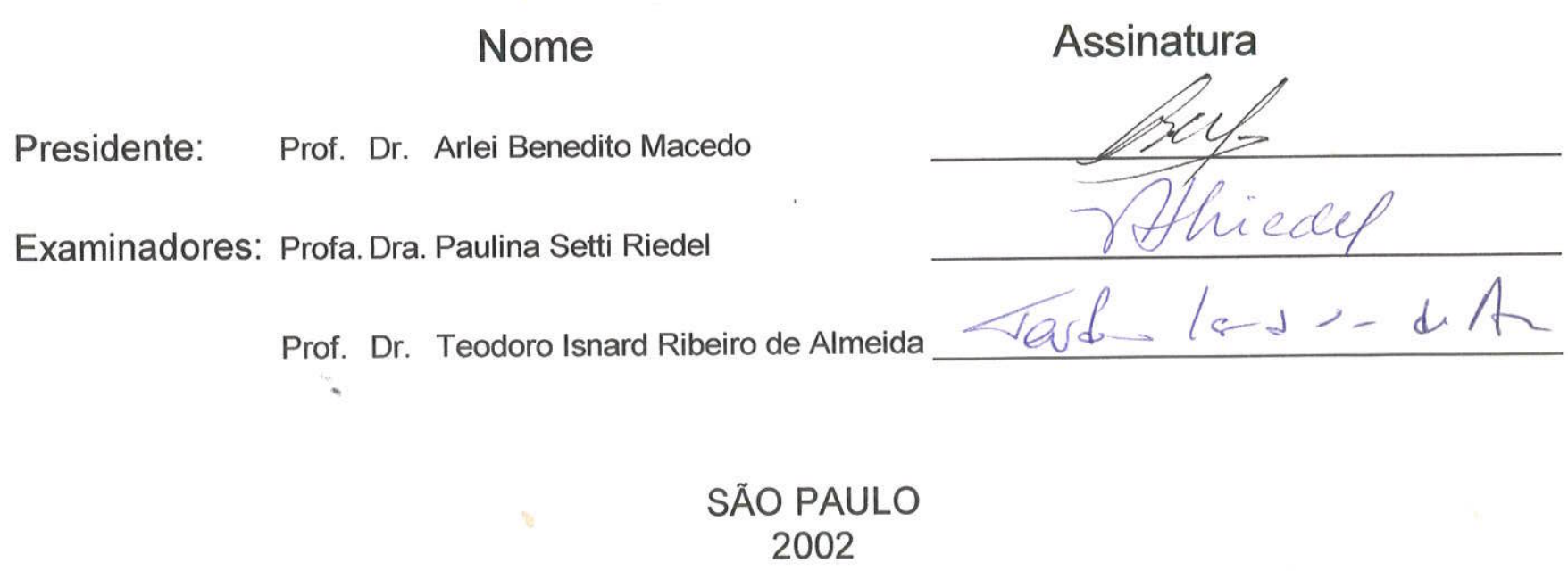

Prof. Dr. Teodoro Isnard Ribeiro de Almeida

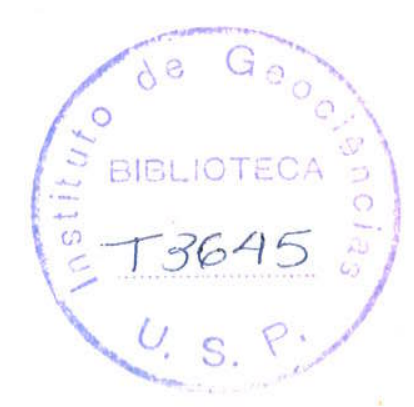


UNIVERSIDADE DE SÃO PAULO

INSTITUTO DE GEOCIÊNCIAS

\section{GEOPROCESSAMENTO E SENSORIAMENTO REMOTO COMO APOIO AO PLANEJAMENTO TERRITORIAL DO MUNICÍPIO DE IPORANGA - SP}

Alexandre Carnier Nunes da Silva

Orientador: Prof. Dr. Arlei Benedito Macedo

DEDALUS - Acervo - IGC

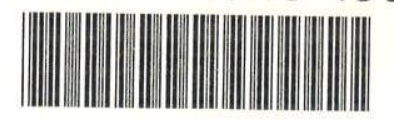

30900011110

\section{DISSERTAÇÃO DE MESTRADO}

Programa de Pós-Graduação em Recursos Minerais e Hidrogeologia

SÃO PAULO

2002 
UNIVERSIDADE DE SÃO PAULO

INSTITUTO DE GEOCIENNCIAS

\title{
GEOPROCESSAMENTO E SENSORIAMENTO REMOTO COMO APOIO AO PLANEJAMENTO TERRITORIAL DO MUNICÍPIO DE IPORANGA -SP
}

\author{
Alexandre Carnier Nunes da Silva \\ Orientador: Prof. Dr. Arlei Benedito Macedo \\ DISSERTAÇÃO DE MESTRADO \\ COMISSÃO JULGADORA
}

Presidente: $\quad$ Prof. Dr. Arlei Benedito Macedo

Examinadores: $\quad \operatorname{Prof}(a) \cdot \operatorname{Dr}(a)$.

$\operatorname{Prof}(a) \cdot \operatorname{Dr}(a)$.

SÃO PAULO

2002 
UNIVERSIDADE DE SÃO PAULO

INSTITUTO DE GEOCIENNCIAS

\title{
GEOPROCESSAMENTO E SENSORIAMENTO REMOTO COMO APOIO AO PLANEJAMENTO TERRITORIAL DO MUNICÍPIO DE IPORANGA - SP
}

\author{
Alexandre Carnier Nunes da Silva \\ Orientador: Prof. Dr. Arlei Benedito Macedo
}

DISSERTAÇÃO DE MESTRADO

Programa de Pós-Graduação em Recursos Minerais e Hidrogeologia

SÃO PAULO

2002 
Ficha catalográfica preparada pelo Serviço de Biblioteca e Documentação do Instituto de Geociências da Universidade de São Paulo

\section{Nunes da Silva, Alexandre Carnier}

Geoprocessamento e Sensoriamento Remoto como apoio ao Planejamento Territorial do Município de Iporanga - SP / Alexandre Carnier Nunes da Silva - São Paulo, 2002. xviii 200p.: il.

Dissertaẫo (Mestrado): IG/USP -

Orient.: Macedo, Arlei Benedito

1. Geoprocessamento 2. Sensoriamento Remoto. 3. Planejamento Territorial: Iporanga. I. Título

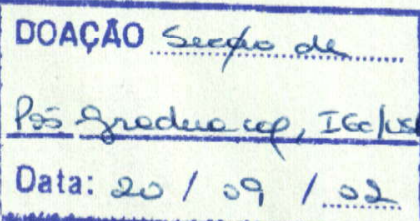


Dedico

aos meus pais, Joaquim e Gema, à minha avó Enedina e ao meu irmão Alberto 


\section{AGRADECIMENTOS}

Agradeço a todas as pessoas e instituições que direta ou indiretamente contribuíram de alguma maneira para a realização deste trabalho.

Ao Curso de Pós-Graduação do Instituto de Geociências da Universidade de São Paulo por toda infraestrutura colocada à disposição.

À Comissão de Pós-Graduação, na pessoa do Prof. Dr. Cláudio Riccomini, pela concessão da prorrogação para a conclusão do trabalho.

Ao Conselho Nacional de Desenvolvimento Científico e Tecnológico, CNPq, pela concessão da bolsa de Mestrado (Processo n. 135872/1995-5).

À Fundação de Amparo à Pesquisa do Estado de São Paulo - FAPESP, pelo auxilio financeiro (Processo n. 00/12696-0).

Ao Prof. Dr. Arlei Benedito Macedo pela orientação e incentivo durante a elaboração deste trabalho.

A todos os professores do Instituto de Geociências da Universidade de São Paulo, que de uma forma ou de outra contribuíram para o desenvolvimento do trabalho; em especial ao Prof. Dr. Teodoro Isnard R. de Almeida, ao Prof. Dr. Ivo Karmann e ao Prof. Dr. Ginaldo A. da Cruz Campanha.

Às funcionárias da biblioteca Brenda, Estela e Sonia, pela gentileza e solicitude.

Às funcionárias da Secretaria de Pós-Graduação, Ana Paula e Magali, pela competência e atenção dispensada.

Ao Prof. Dr. Dalton Valeriano, do Instituto Nacional de Pesquisas Espaciais, pelas sugestões no tratamento dos dados de sensoriamento remoto.

Aos pesquisadores da Secretaria do Meio Ambiente (CPLA), Ana Xavier, Elisabeth Büschel e Martinus Filet, pelo fornecimento dos dados do macrozoneamento do Vale do Ribeira.

Ao pesquisador do Instituto Agronômico de Campinas, Pedro Donzelli, pelo fornecimento dos mapas de capacidade de uso e aptidão agrícola.

Ao Marcos S. Campos, do DNPM, pela amizade e auxílio na elaboração dos dados de títulos minerários.

À Prefeitura de Iporanga, pelo apoio nos trabalhos de campo, em especial aos profissionais da Casa da Agricultura (CATI). 
Aos moradores de Iporanga agradeço a receptividade e simplicidade de seu modo de vida, exemplos inesquecíveis de dignidade e persistência.

Aos amigos da Pós-Graduação, Marcelo Rocha, George de Barros, Marcelo Gramanni e Veridiana Martins, pela contribuição na revisão do texto, apoio, críticas e sugestões.

Aos companheiros da sala 106, Carlos Araújo, Sérgio Liotti, Sidney Goveia, pelo incentivo e discussões. À Neide Watanabe pelo importante apoio nos trabalhos de campo e discussões.

Aos amigos do Instituto de Pesquisas Tecnológicas, IPT - DIGEO, em especial ao José Ridente, Eduardo Macedo e Kátia Canil, pelo incentivo e apoio na etapa final do trabalho. Ao Oswaldo Augusto Filho, pela contribuição, essencial nas análises sobre os processos de dinâmica superficial, e exemplo de competência profissional.

Aos amigos da Graduação, especialmente à Márcia Saito, Lucilene Martins, Ivo Júnior, Roseli Teruya, Luciano Gobbo, Valéria Guimarães e Ivandra Mattos, pela incentivo e amizade.

A minha família pelo constante apoio, ajuda e compreensão, principalmente nos momentos mais difíceis do trabalho.

Agradeço em especial a minha companheira, Fabiane...obrigado pela presença e carinho nos momentos mais difíceis e importantes...sem você a conclusão deste trabalho teria sido muito mais difícil. 
ÍNDICE DE TABELAS

RESUMO

ABSTRACT

CAPÍTULO 1 - INTRODUÇÃO

1.1 OBJETO DA PESQUISA

1.3 JUSTIFICATIVA....

1.4 ÁREA dE ESTUdo

CAPÍTULO 2 - OBJETIVOS.

1.2 OBJETIVOS GERAIS

1.2.1 Objetivos especificos e atividades realizadas na pesquisa

CAPÍTULO 3 - ASPECTOS GERAIS

3.1 VALE DO RIBEIRA

3.1.1 Histórico da ocupação do Vale do Ribeira.

3.1.2 História de Iporanga

3.1.2.1 O Ciclo do Ouro

3.1.2.2 O Ciclo do Chumbo/Prata

3.2 O MUNICIPIO DE IPORANGA.

3.2.1 Unidades de conservação no municipio

3.3 CATEGORIAS DE UNIDADES DE CONSERVAÇão

3.3.1 Unidades de Proteção Integral.

3.3.1.1 Estações ecológicas

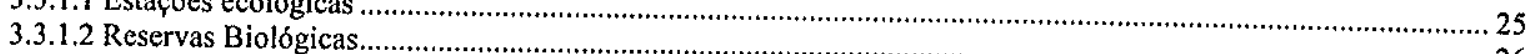

3.3.1.3 Parque Nacional

3.3.2 Unidades de Uso Sustentável.

3.3.2.1 Áreas de Proteção Ambiental (APAs)

3.3.2.2 Áreas de Relevante Interesse Ecológico (ARIEs)

3.3.2.3 Reservas da Biosfera (REBIOs)

27

3.4 SISTEMAS DE INFORMAC donas de manejo nas unidades de conservação..................................................2. 28

烈

.

3.4.3 Fontes de dados

3.4.4 Estruturas de representação de dados espaciais

. 32

3.4.4.2 Estruturas Vetoriais

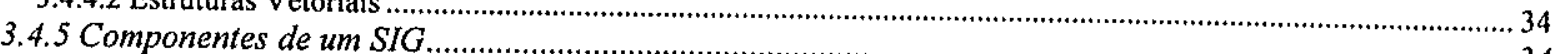

3.4.5.1 Sistema Gerenciador de Banco de dados...

3.4.5.1.1 Base de dados

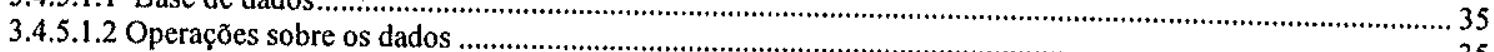

CAPÍTULO 4 - REVISÃO BIBLIOGRÁFICA

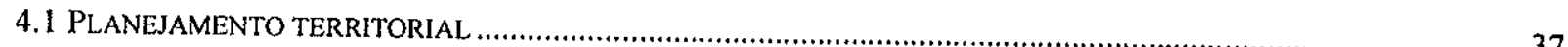

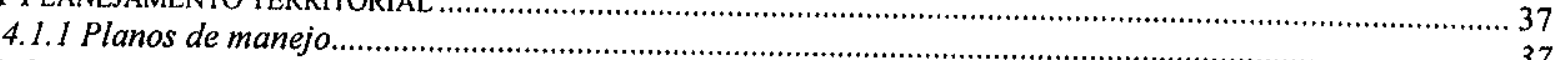

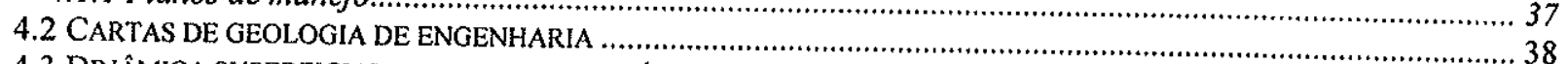

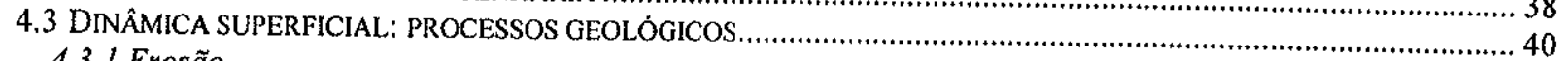

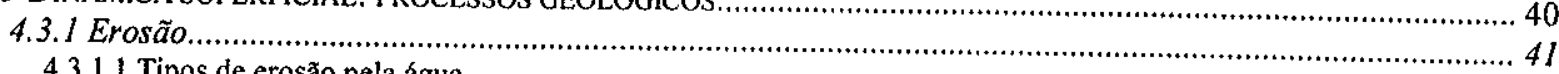

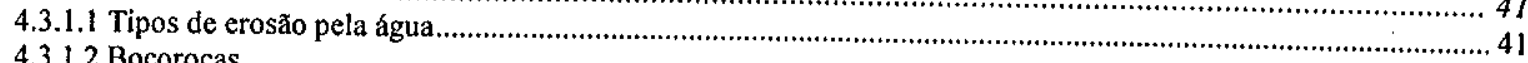

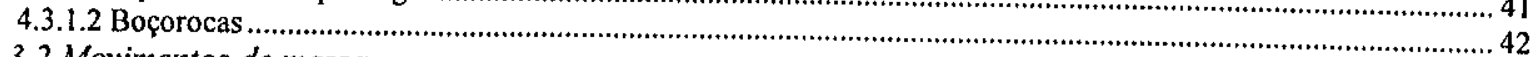

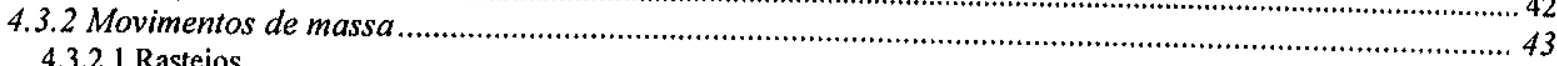

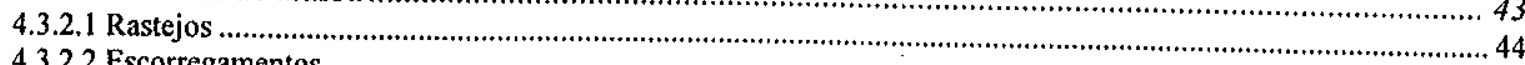

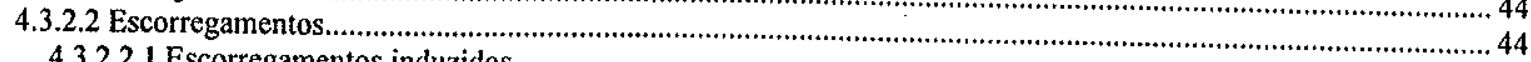

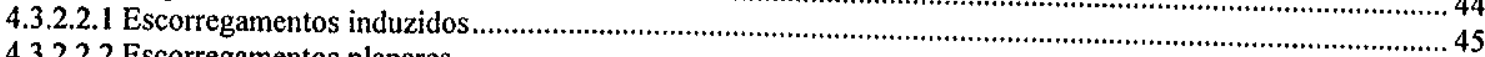

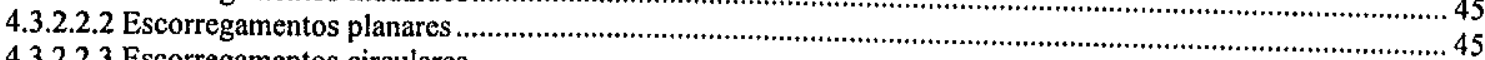

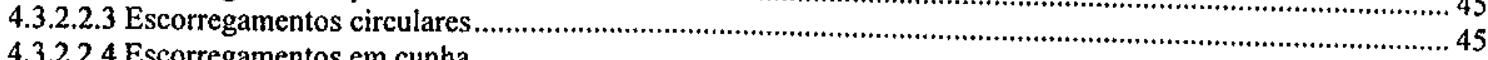

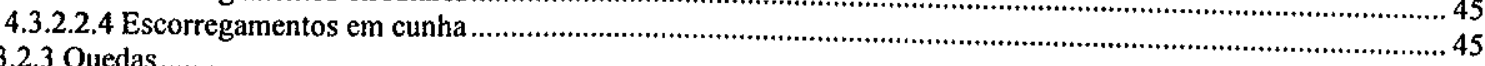

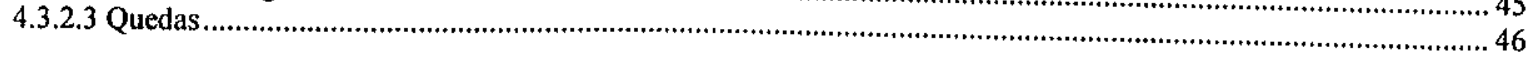


4.3.2.4 Corridas

4.3.3 Assoreamento.

.

4.3.5 Subsidências

4.4 ANÁLISE DE SUSCETIBILIDADE

4.5.I Unidades territoriais básicas na geotecnia

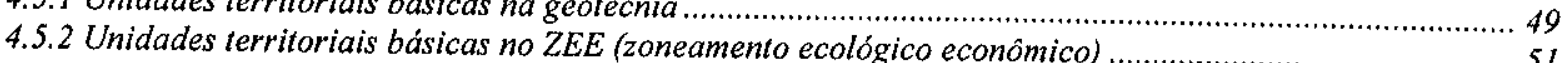

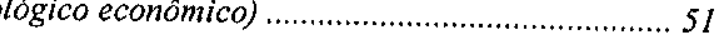

4.5.3.1 Procedimentos operacionais

4.5.3.2 Fragilidade potencial natural (indices de dissecaçăo do relevo)

4.5.3.2.1 Solos $\ldots$

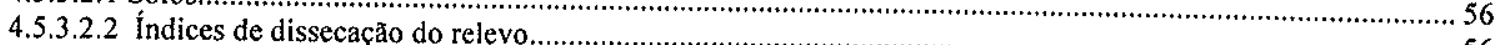

4.5.3.2.3 Uso da Terra / Cobertura vegetal

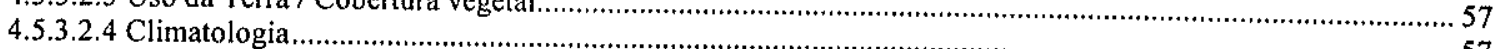

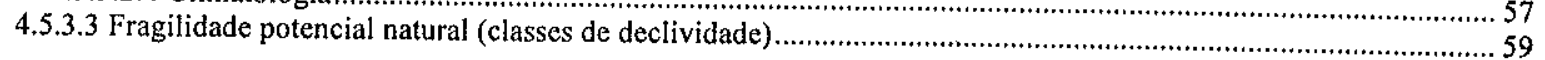

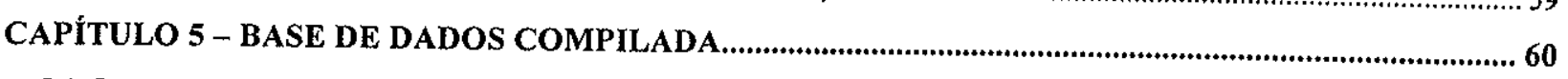

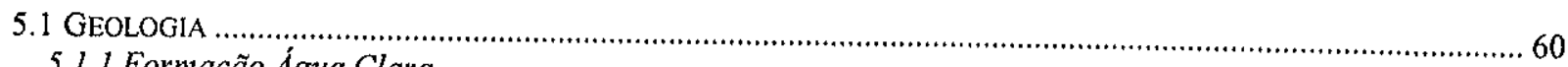

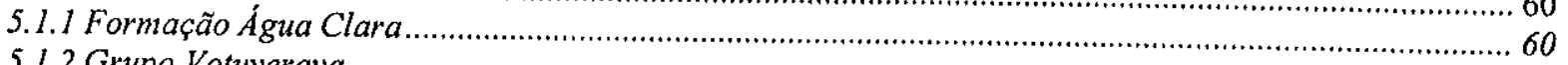

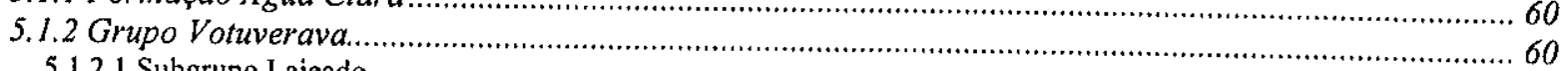

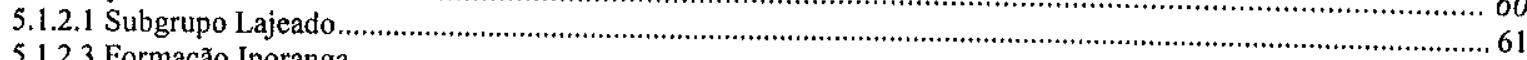

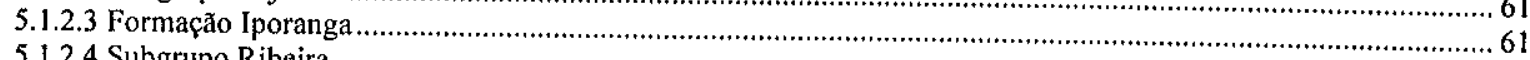

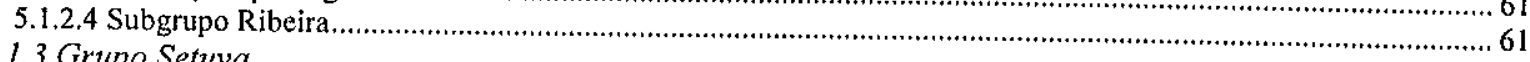

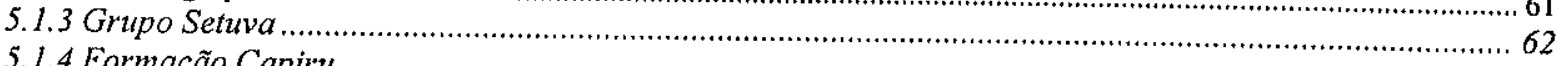

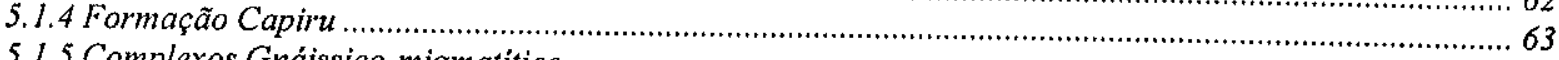

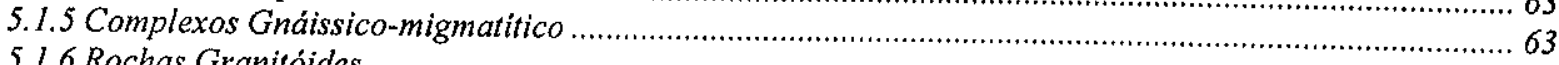

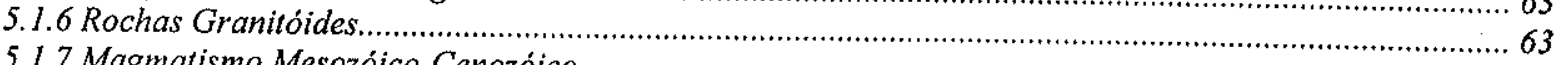

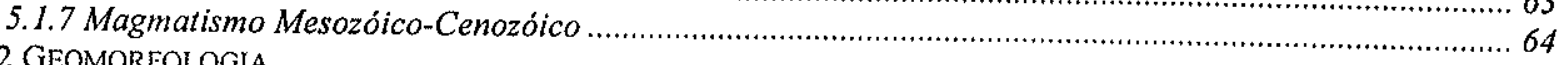

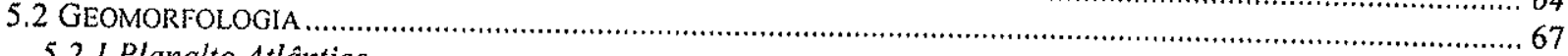

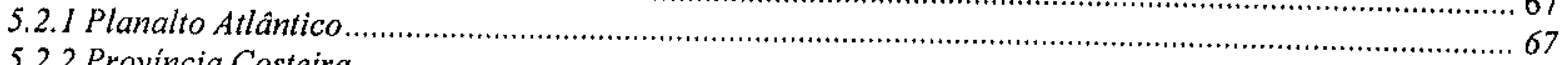

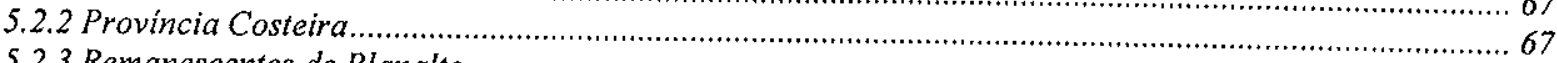

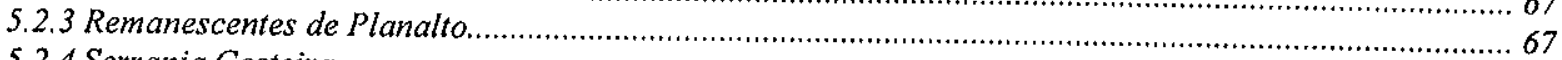

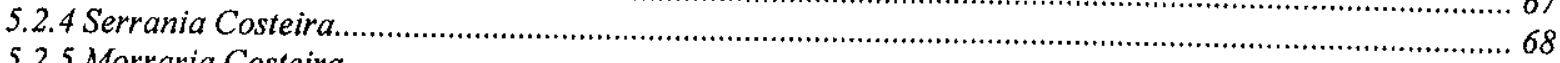

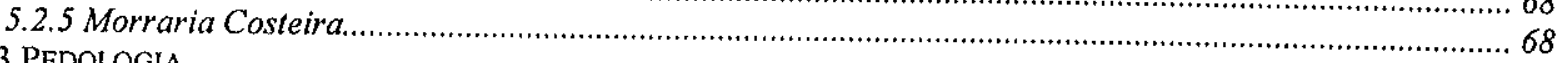

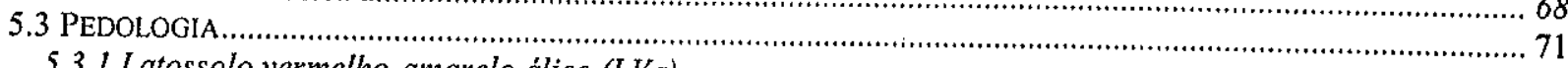

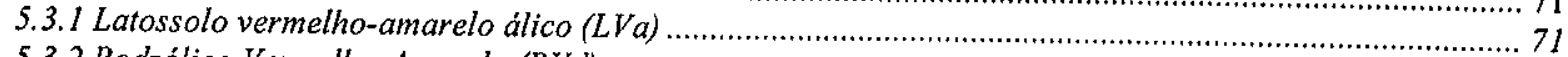

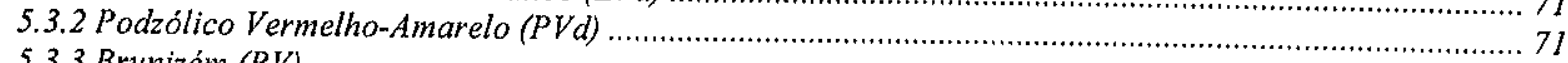

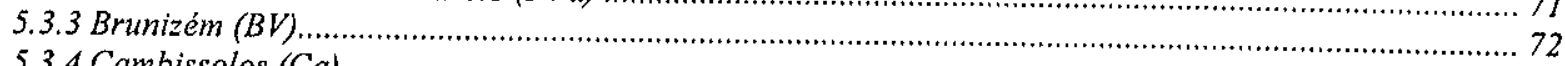

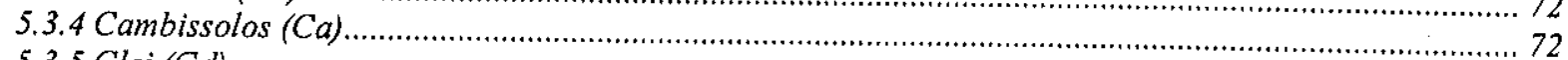

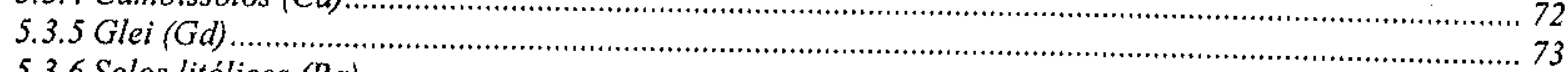

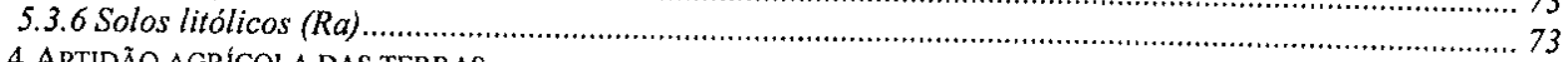

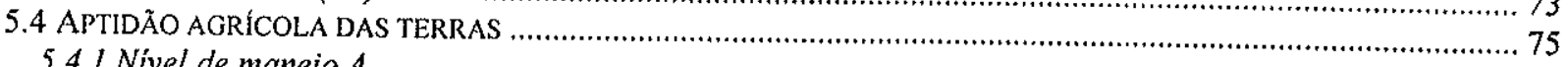

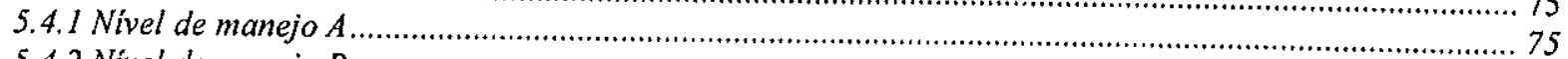

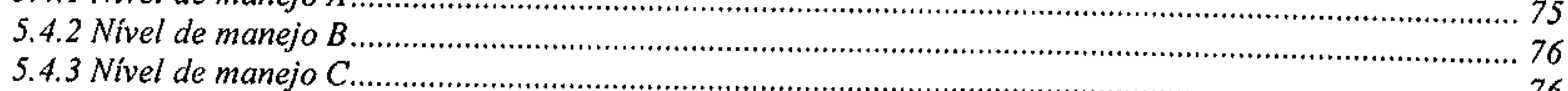

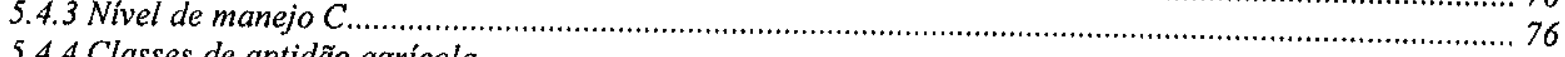

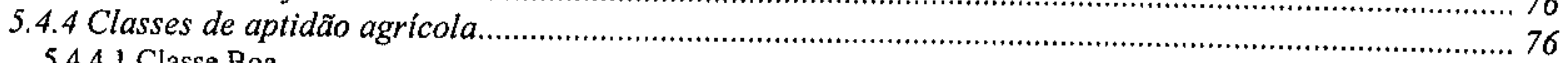

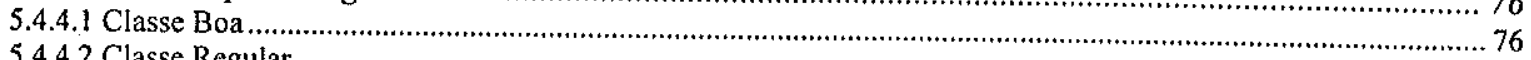

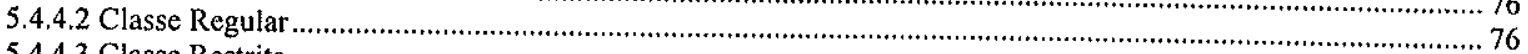

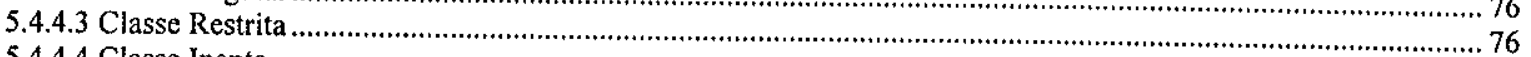

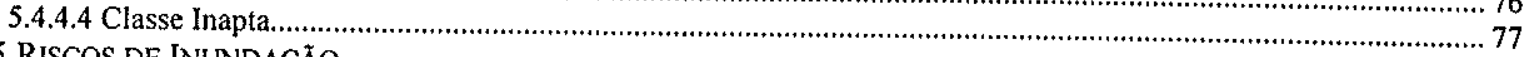

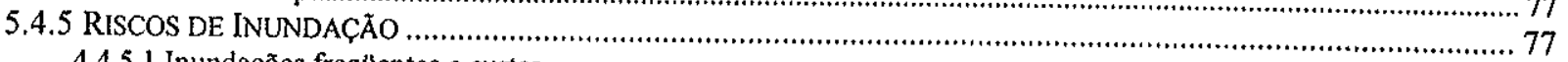

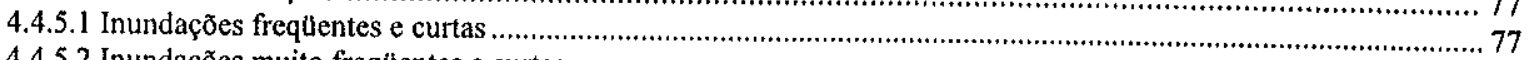

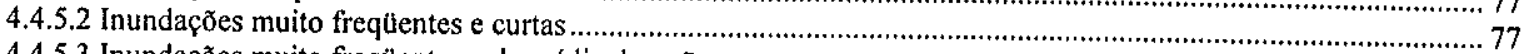

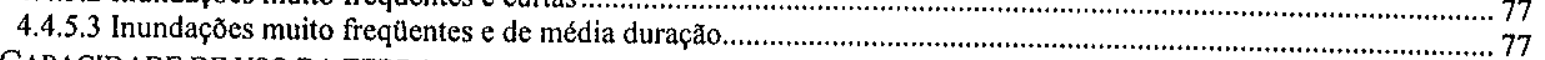

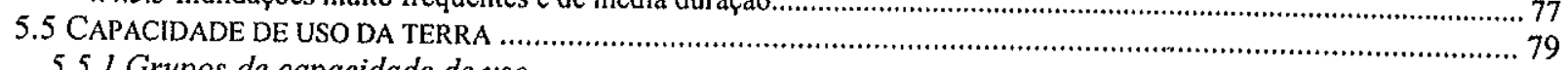

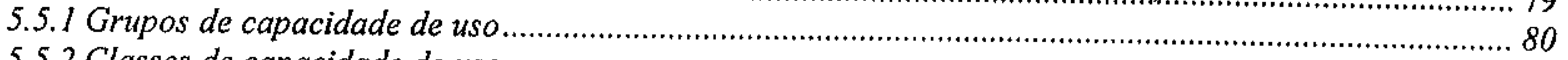

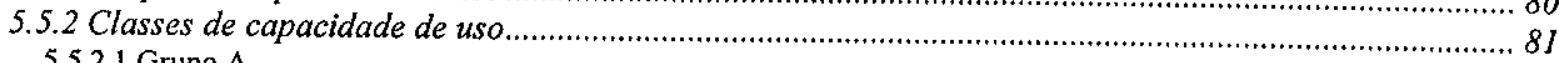

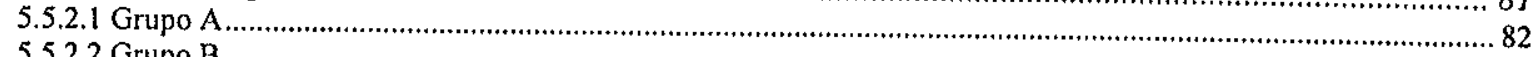

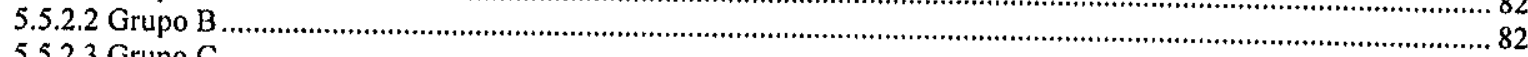

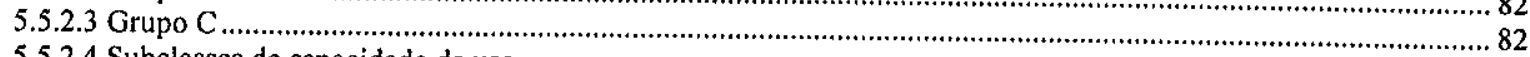

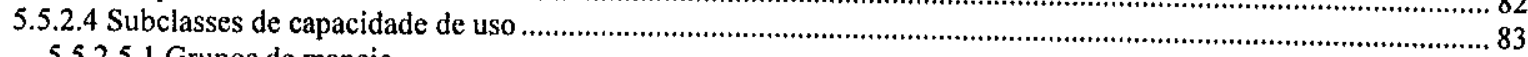

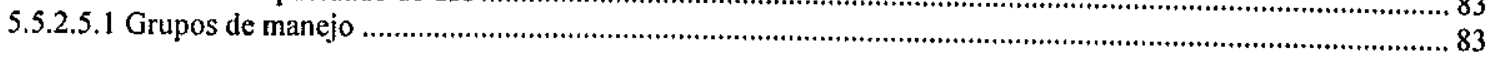

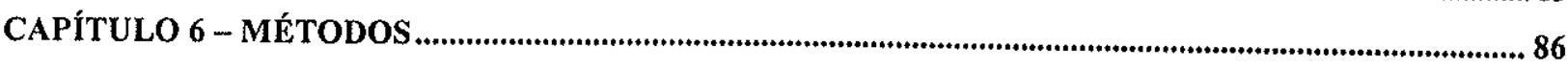

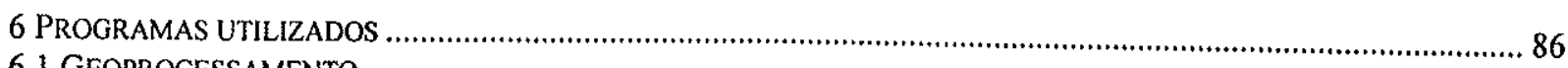

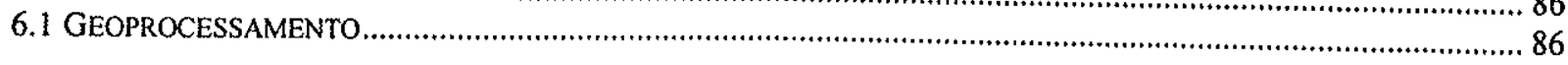


6.1.1 Entrada de dados.

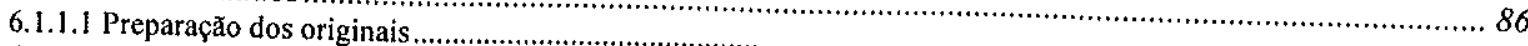

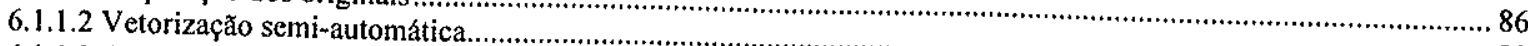

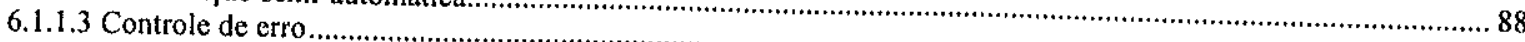

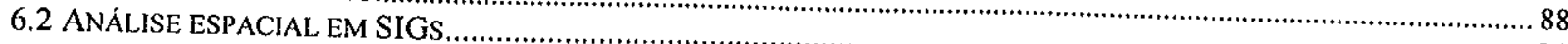

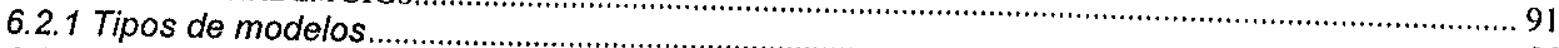

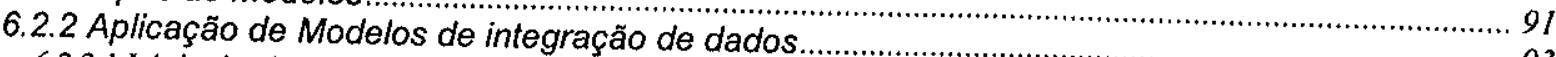

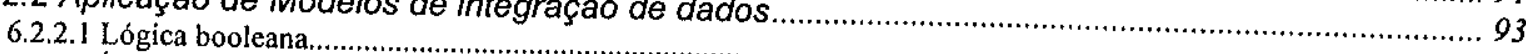

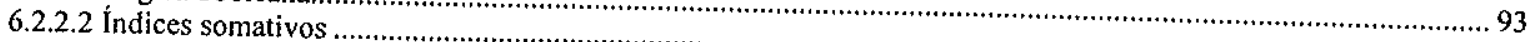

6.2.2.2.1 Mapas de evidência binários (Binary Wheights)

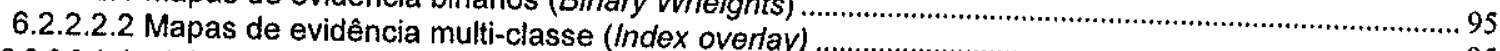

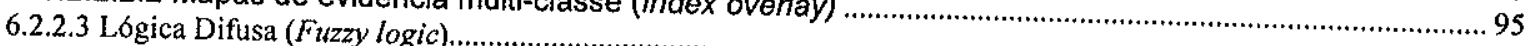

6.2.2.4 Processo analítico hierárquico (AHP-Analytical Hierarchy Process)

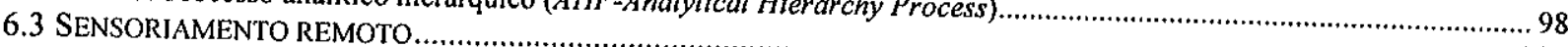

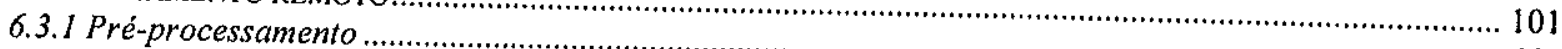

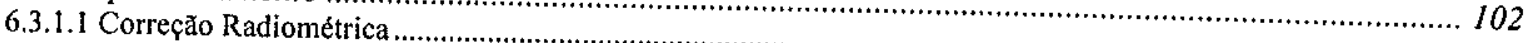

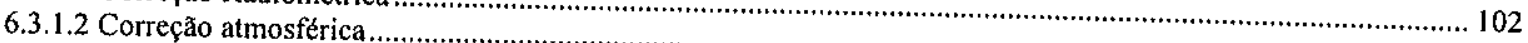

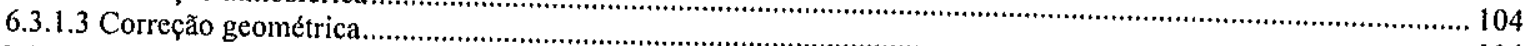

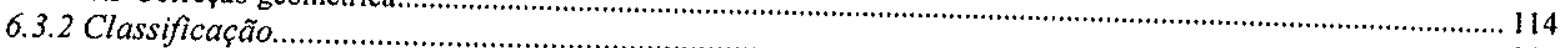

6.3.2.1 Classificaçđ̃o nđ̃o supervisionada

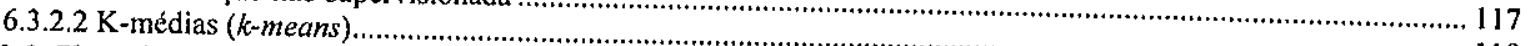

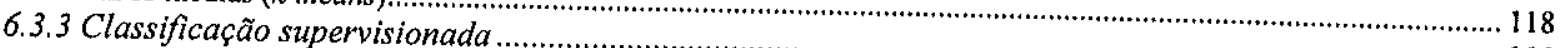

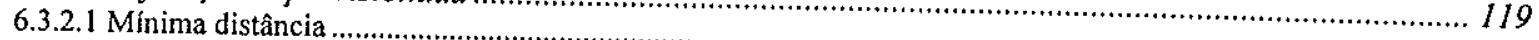

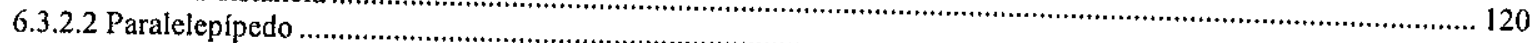

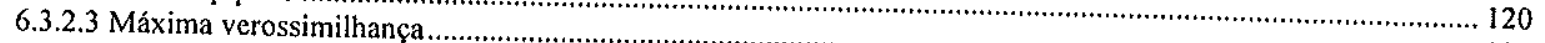

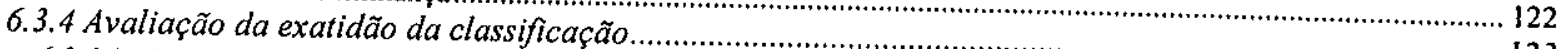

6.3.4.1 Matriz de erro da classificação $\ldots$

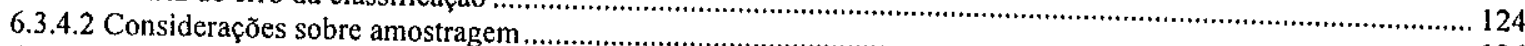

6.3.4.3 Avaliação das Matrizes de erro

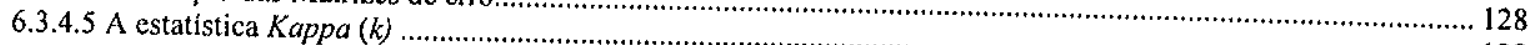

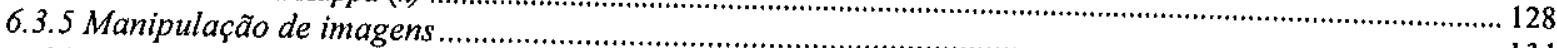

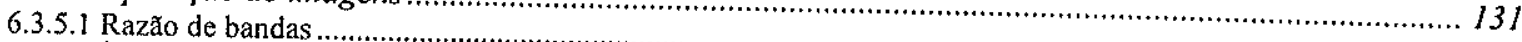

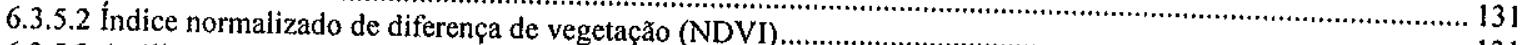

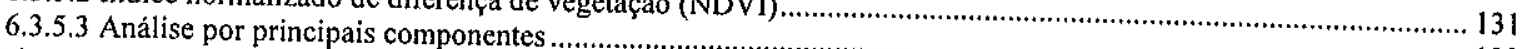

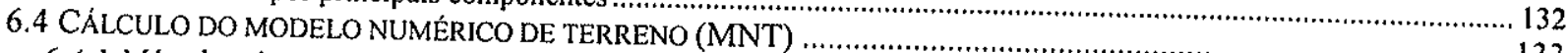

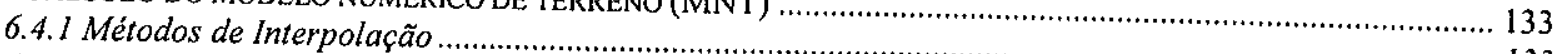

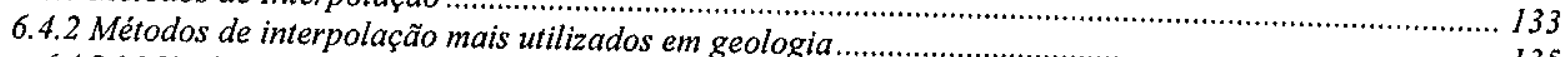

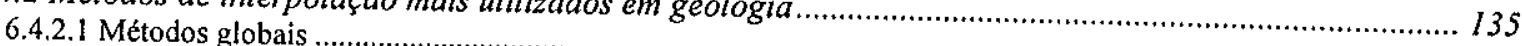

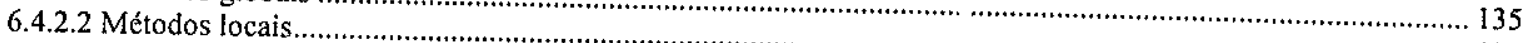

6.4.2.3 Técnica de ajuste de placas delgadas discretizadas (discretised thin plate spline technique)

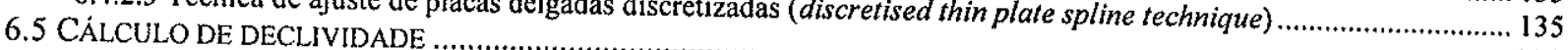

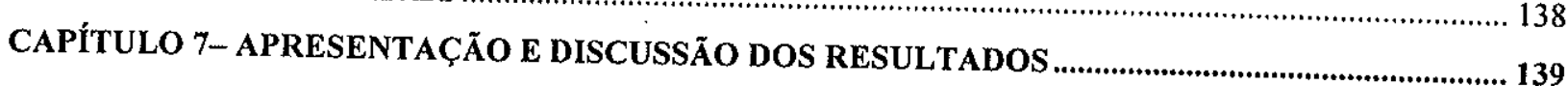

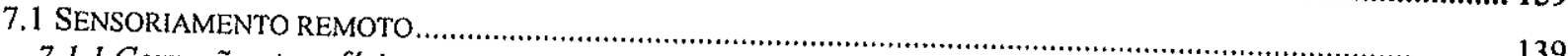

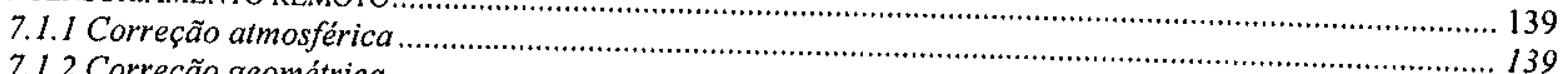

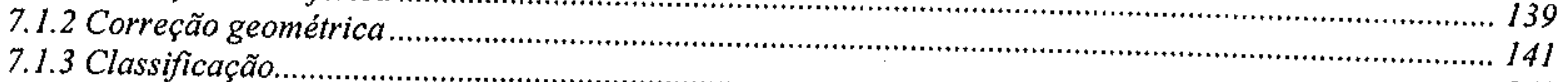

7.1.4 Evolução da cobertura da terra (1990-2000)

7.1.4.1 Análise da cobertura da terra nas unidades de conservação.

7.1.4.2 Evolução da cobertura da terra nas unidades de conservação....................................................................154

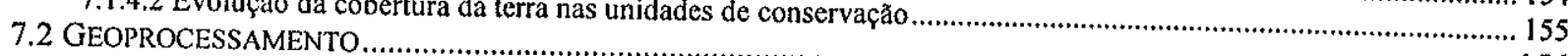

7.2.1 Carta de suscetibilidade aos movimentos de massa

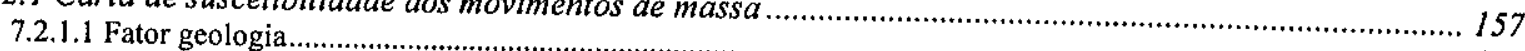

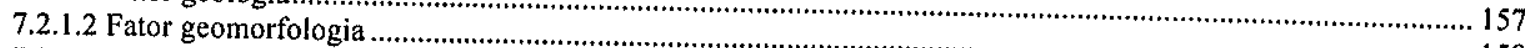

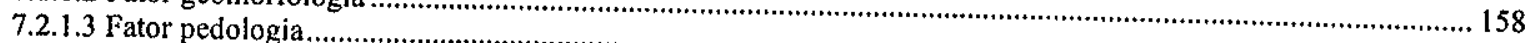

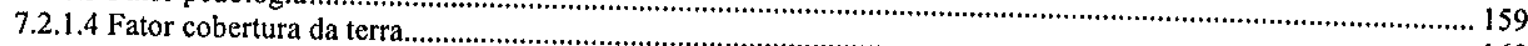

7.2.1.5 Fator declividade

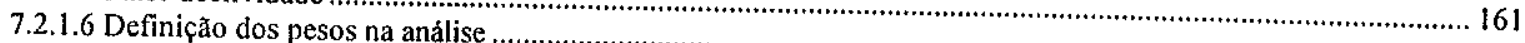

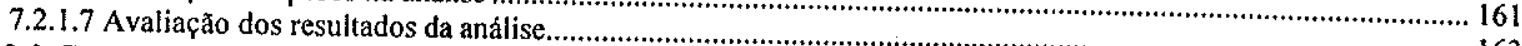

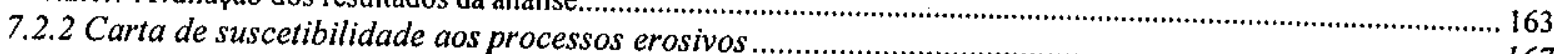

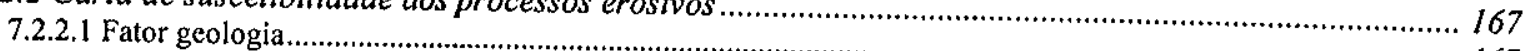

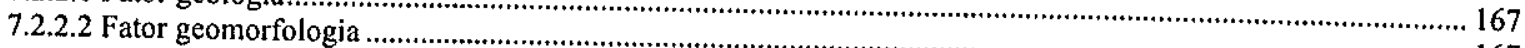

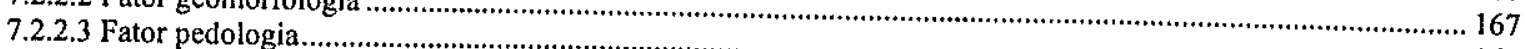

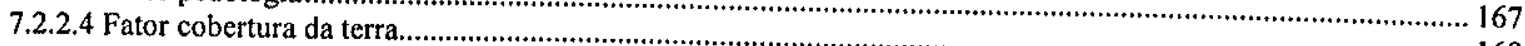

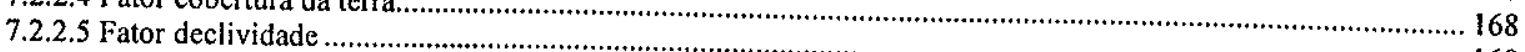

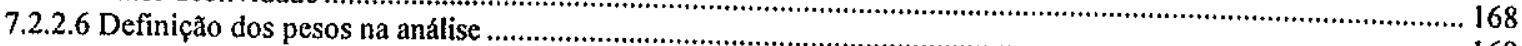

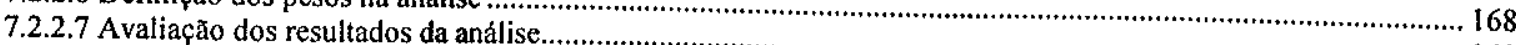

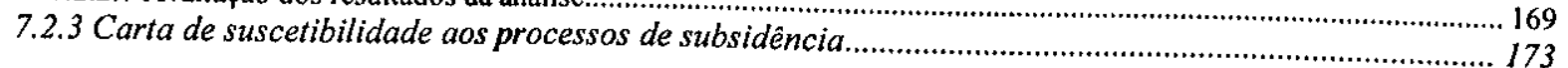


7.2.3.1 Fator geologia

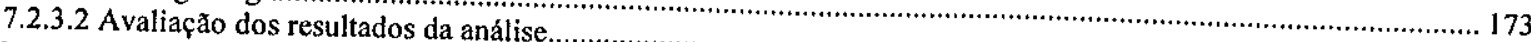

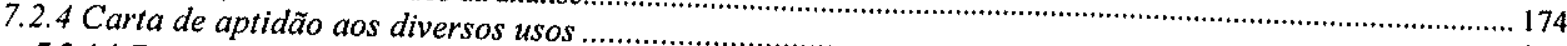

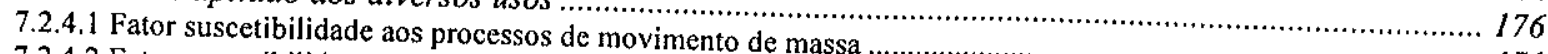

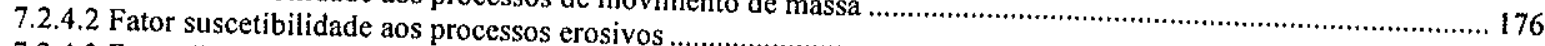

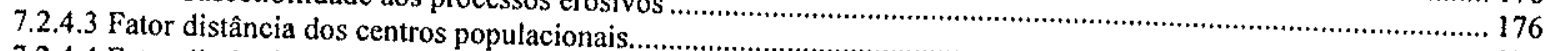

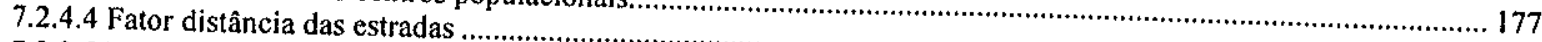

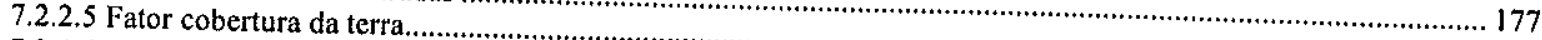

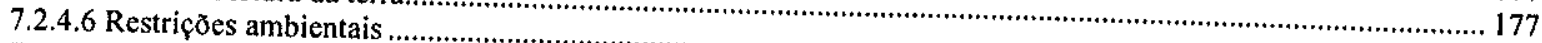

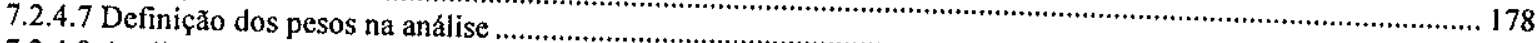

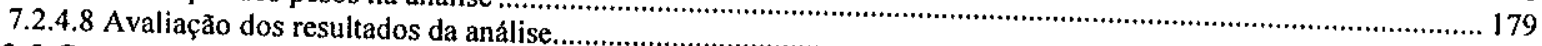

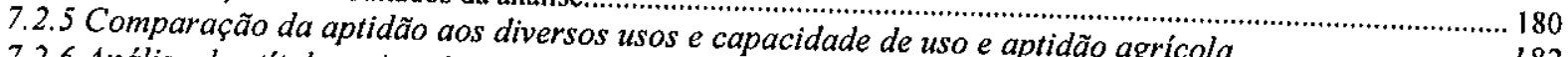

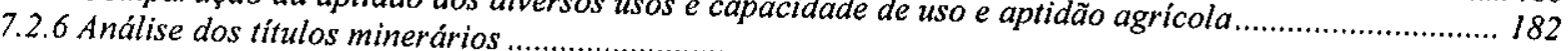

CAPÍTULO 8 - CONCLUSÕ ES

REFERÊNCIAS 


\section{ÍNDICE DE FIGURAS}

Página

Figura 1.1 - Localização e vias de acesso ao municipio de Iporanga.

Figura 3.1 - Mapa das Unidades de Conservação no municipio de Iporanga

Figura 3.2 - (A) Modelo de representação matricial; (B) Representação vetorial da rede de drenagem; (C) Representação matricial da rede de drenagem

Figura 3.3 - Estrutura matricial representando uma base de dados com temas de vegetação, pedologia e uso do solo

Figura 4.1 - Seção de um rio ou drenagem com os principais tipos de leito fluvial (Christofoletti, 1981).

Figura 5.1 - Mapa geológico compilado (Campanha 1999, 2000).

Figura 5.2 - Mapa geomorfológico compilado (SMA, 1996).

Figura 5.3 - Mapa pedológico compilado (Lepsch, 1990).

Figura 5.4 - Mapa compilado de aptidão agricola das terras (Lepsch, 1990).

Figura 5.5 - Classes de capacidade de uso e relações com aptidão e limitações conforme utilização da terra. 81

Figura 5.6 - Esquema dos grupos, classes, subclasses e unidades de capacidade de uso (Peralta, 1963, apud Lepsch 1991).

Figura 5.7 - Mapa compilado de capacidade de uso das terras (Lepsch, 1990).

Figura 6.1 - Georreferenciamento da pelicula rasterizada através do processamento Warp no módulo IRAS-B (X indicam os pontos a serem ajustados; + indicam as coordenadas de referência).

Figura 6.2 - Vetorização semi-automática do arquivo rasterizado no programa I/GEOVEC.

Figura 6.3 - Opções de padronização do processo de vetorização semi-automática disponiveis no programa I/GEOVEC

Figura 6.4 - Gráfico mostrando a função de associação difusa (fuzzy) para um conjunto de observaçöes para os quais "os niveis de arsênio são anomalos".

Figura 6.5 - Gráfico mostrando a função de associação difusa (fuzzy) para um conjunto de observações para os quais "os valores de declividade são altos"

Figura 6.6 - Efeitos da mudança de estação nos ângulos de elevação solar (o ângulo zênite solar $=90^{\circ}$ menos o ângulo de elevação solar).

Figura 6.7 - Esquema mostrando o caminho da radiação eletromagnética (REM) e suas interações até sua captação pelo sensor.

Figura 6.8 - Conjunto de dados, de duas bandas espectrais, exemplificando como o processo de classificação por mínima distância pode utilizar um vetor de média de uma classe com pequena variancia na resposta multiespectral. . 121 Figura 6.9 - Comparação entre as menores "regiões de decisão" S e W (areia e água) e maiores U e H (áreas urbanas e pastagens) pela abordagem do paralelepipedo

Figura 6.10 - Valores de probabilidade associados ao conjunto de pixels representando as classes analisadas 
Figura 6.11 - Contornos de eqüiprobabilidade que representam as regiőes de decisão para o classificador por máxima verossimilhança.

Figura 6.12 - Comparação entre o produto gerado pelo processo manual (a) e demais algoritmos.

Figura 6.13 - Comparação entre o mapa de contorno gerado com o modelo interpolado por TPS (TOPOGRID) (a); e dados de entrada (curvas de nivel, pontos cotados e drenagens) (b)

Figura 6.14 - Exemplos de rampas com valores de declividade calculados em unidades de grau e porcentagem. .... 138 Figura 7.1 - Composição colorida relativa a faixa espectral do visivel (3R2G1B). Detalhes: (a) antes da aplicação da correção atmosférica; (b) após aplicação da correção atmosférica, com o mesmo ajuste linear de contraste.

Figura 7.2 - Resultado da classificação não supervisionada.

Figura 7.3 -Sintese estatística das classes geradas em relação às bandas originais.

Figura 7.4 -Sintese estatística das classes geradas em relação às bandas derivadas

Figura 7.5 - Comparação entre as fotografias aéreas (1:35.000) (A), composição 4R5G7B (B), classificação inicial com 16 classes (C), e classificação final com 5 classes (D).

Figura 7.6 - Apresentação de alguns pontos de campo representativos dos tipos de coberturas, determinados na classificação, com fotografias panorâmicas

Figura 7.7 - Síntese da evolução do uso do solo no municipio de lporanga.

Figura 7.8 - Resultado da análise para processos de movimento de massa

Figura 7.9 - Pontos de campo mostrando áreas de alta suscetibilidade aos processos de movimento de massa, com desenvolvimento de processos

Figura 7.10 - Resultado da análise para processos erosivos.

Figura 7.11 - Ponto de campo mostrando áreas delimitadas como de alta suscetibilidade aos processos erosivos, com desenvolvimento de processos

Figura 7.12 - Resultado da análise de suscetibilidade aos processos de subsidência

Figura 7.13 - Resultado da análise de aptidão do mejo físico aos diferentes tipos de uso e ocupação do solo. 181

Figura 7.14 - Resultado da análise dos títulos minerários, mostrando a fase atual dos títulos e a relação com os limites das unidades de conservação. 


\section{ÍNDICE DE TABELAS}

Página

Tabela 3.1 - Concessões imperiais de mineração na região do PETAR. 12

Tabela 3.2 - Relação das descobertas minerais no Alto Ribeira no periodo de 1970 a 1995 16

Tabela 3.3 - Dinâmica demográfica do Municipio de Iporanga. Estimativas geradas pela Fundação SEADE utilizando dados dos sensos disponiveis até 2000 .

Tabela 3.4 - Unidades de Conservação do município de Iporanga.

Tabela 3.5 - Compatibilidade de zonas de manejo e categorias de manejo de unidades de conservação.

Tabela 4.1 - Tipos de cartas geotécnicas produzidas no Brasil.

Tabela 4.2 - Caracteristicas principais dos grandes grupos de processos de escorregamento no lato sensu (Augusto Filho, 1992),

Tabela 4.3 - Principais agentes e causas dos escorregamentos (Guidicini e Nieble, 1976, apud Augusto Filho, 1994)

Tabela 4.4 - Principais fatores/condicionantes naturais e ações antrópicas indutoras das inundações (IPT, 1999). ...... 48

Tabela 4.5 - Valores de Estabilidade de Unidades de Paisagem. .52

Tabela 4.6 - Valores de EstabilidadeNuinerabilidade para as Unidades Litológicas. 52

Tabela 4.7 - Valores de estabilidade/vulnerabilidade para a dimensão interfluvial média ara locais que dispöem de cartas topográficas em escala menor ou igual a 1:25.000.

Tabela 4.8 - Valores de estabilidade/vulnerabilidade para as classes de solos.

Tabela 4.9 - Valores de estabilidade/vulnerabilidade para as diferentes formações Florestais.

Tabela 4.10 - Classificação proposta por Ross (1990) para a classificação das unidades ecodinâmicas de Tricart (1977)

Tabela 4.11 - Classes de Fragilidade dos solos em cinco categorias (Ross, 1994).

Tabela 4.12 - Matriz dos indices de dissecaçăo do relevo (Ross, 1992).

Tabela 4.13 - Classificação das categorias morfométricas (Ross, 1992).

Tabela 4.14 - Graus de proteçăo do solo segundo a cobertura vegetal (Ross, 1994)

Tabela 4.15 - Niveis hierárquicos dos comportamentos pluviométricos (Spörl, 2001).

Tabela 4.16 - Intervalos de declividade utilizados na classificaçăo.

Tabela 5.1 - Descrição das caracteristicas das unidades representadas no mapa geomorfológico compilado (SMA, 1996)

Tabela 6.1 - Valores aceitáveis de erro em bases cartográficas conforme escala. 90

Tabela 6.2 - Classificaçăo dos modelos utilizados em geologia. .92 
Tabela 6.3 - Abordagens da modelagem de dados aplicada em SIG, divididos em modelos baseados no conhecimento (knowledge-driven) e nos dados (data-driven).

Tabela 6.4 - Escala de importância relativa empregada na análise pareada dos fatores na técnica AHP. 99

Tabela 6.5 - Escala continua utilizada no programa IDRISI para comparação relativa entre fatores envolvidos na determinação de pesos para poderação em uma análise multi-critério

Tabela 6.6 - Exemplo de matriz de comparação pareada para análise da importância relativa de 5 fatores na análise para desenvolvimento de distritos industriais.

Tabela 6.7 - Pesos derivados do cálculo do auto-vetor principal da matriz de comparação pareada. A razão de consistência indica a probabilidade da pontuaçăo ter sido obtida ao acaso

Tabela 6.8 - Comparação entre as larguras das bandas espectrais e resolução espacial dos sensores TM e ETM+. . 102

Tabela 6.9 - Fontes utilizadas para definição dos parâmetros de calibração radiométrica do Sensor TM-Landsat, utilizados pelo programa IDRISI v. 2.0

Tabela 6.10 - Dados de radiância utilizados para o cálculo do Gain e Offset das imagens, segundo a data de aquisição das imagens, para cada fonte citada na Tabela 6.7

Tabela 6.11 - Dados de radiância utilizados para o cálculo do Gain e Offset das imagens, segundo a data de aquisição das imagens, para cada fonte citada na Tabela 6.10

Tabela 6.12 - Valores de gain e offset contidos nos arquivos descritores das imagens no formato INPE*, para cada imagem adquirida.

Tabela 6.13 - Valores de gain e offset contidos nos arquivos descritores das imagens fornecidas pelo INPE.

Tabela 6.14 - Condições atmosféricas e modelo relativo de espalhamento aplicado para correção atmosférica. 110

Tabela 6.15 - Relação entre os valores médios obtidos na estimativa do pixel escuro para a banda TM1, e os modelos relativos de espalhamento (condições atmosféricas)

Tabela 6.16 - Relaçăo entre os modelos relativos de espalhamento para cada banda espectral do satélite Landsat 5 , mostrando a participação de cada banda espectral no espalhamento total, para cada modelo.

Tabela 6.17 - Fatores de multiplicação para a predição dos valores de correçăo atmosférica, para cada banda, escolhendo como banda espectral para correção inicial a banda TM 1

Tabela 6.18 - Valores de Gain e Offset para as bandas espectrais do Landsat 5, e normalização do fator de ganho (Norm i)

Tabela 6.19 - Comparação dos valores aplicáveis de correção atmosférica para cada método descrito

Tabela 6-20 - Comparação de métodos utilizados para interpolaçăo dos valores da imagem corrigida geometricamente.

Tabela 6.21 - Matriz de erro resultante dos dados de treinamento para classificação supervisionada.

Tabela 6.22 - Matriz de erro resultante dos dados de teste selecionados aleatoriamente na imagem resultante da classificação supervisionada. 


\section{RESUMO}

Técnicas de geoprocessamento e sensoriamento remoto foram aplicadas como apoio ao planejamento territorial do município de Iporanga (SP). A área insere-se em uma das regiões mais carentes do estado de São Paulo, o Vale do Ribeira, e apresenta elevada diversidade biológica e geológica, associando remanescentes da Mata Atlântica e terrenos cársticos, sendo sujeita a restrições ambientais. A caracterização do meio físico empregou a elaboração de cartas de suscetibilidade aos movimentos de massa, processos erosivos e subsidência. Nas cartas de suscetibilidade aos movimentos de massa e processos erosivos empregou-se a técnica de análise multicritérios, com a combinação de fatores pelo método de ponderação linear, auxiliado pelo processo analítico hierárquico (AHP) na definição dos pesos dos fatores: geologia, geomorfologia, pedologia, declividade e cobertura da terra. A carta de suscetibilidade aos processos de subsidência empregou somente a análise dos dados de geologia. $A$ carta de aptidão aos diversos usos, elaborada levando em consideração as cartas de suscetibilidade, incluiu a análise das áreas legalmente protegidas como Parques, Áreas de Proteção Ambiental e Áreas de Proteção Permanente. Apenas parcelas muito pequenas da área do município mostraram-se adequadas para produção agrícola (532 ha) ou para expansão urbana (3534 ha). A análise dos títulos minerários mostra o aumento na procura de calcário e persistência de títulos de lavra no entorno e no interior do PETAR e Intervales. As técnicas de geoprocessamento e sensoriamento remoto mostraram-se adequadas para a realização de diagnósticos e prognósticos integrados para planejamento territorial. 


\title{
GIS AND REMOTE SENSING AS A SUPPORT TO LAND USE PLANNING OF IPORANGA MUNICIPALITY - SP
}

\begin{abstract}
GIS and remote sensing techniques were applied to support land use planning of the Iporanga municipality. The studied area belongs to the Ribeira Valley, one of the poorest areas of the São Paulo State, and presents high biological and geological diversity, with Atlantic Forest and karstic terrain. The physical environment study was done by making maps of susceptibility to mass movements, erosive processes, and subsidence. In the mass movement and erosive processes susceptibility maps were used the multi-criteria evaluation technique, considering as factors geology, geomorphology, soils, slope and land cover, with weight linear combination of factors and defining weights by the analytic hierarchic process. For the map of susceptibility to subsidence only reclassification of geological data was made. The land use suitability map, intended for general use, was made considering the susceptibility maps, including the areas protected by law, as Parks, environmental protection areas and permanent protection areas. Only a small part of the municipal area is adequate to agricultural use (532 ha) or urban development ( $3534 \mathrm{ha}$ ). The analysis of mining properties shows an increase demand for limestone and persistence of mining titles inside and around PETAR and Intervales State Parks. The GIS and remote sensing techniques applied were considered adequate for integrated diagnosis and forecasts for land use planning.
\end{abstract}




\section{CAPÍTULO 1 - INTRODUÇÃO}

\subsection{Objeto da pesquisa}

A presente pesquisa discute a utilização das técnicas de geoprocessamento e de sensoriamento remoto, com enfoque na caracterização da dinâmica do meio físico e de suas inter-relações com as diferentes formas de uso e ocupação, para subsidiar as ácões de planejamento territorial de municípios.

O planejamento territorial apoiado nas técnicas de geoprocessamento e sensoriamento remoto fornece as bases para a realização de diagnósticos e prognósticos integrados e dinâmicos, permitindo aos gestores públicos conhecer as fragilidades e potencialidades das diferentes regiões municipais, em uma perspectiva de desenvolvimento sustentável, com melhoria das condições de vida da população e de conservação do meio ambiente.

A etapa de aplicação da pesquisa foi desenvolvida na região do Vale do Ribeira que caracteriza-se como uma das regiões do estado de São Paulo com grande diversidade, do ponto de vista geológico, incluindo uma variedade de ambientes e tipos de formação, com destaque para a ocorrência de rochas carbonáticas que apresentam desenvolvimento de carste, formando uma das províncias espeleológicas mais importantes do Brasil, a província Espeleológica do Vale do Ribeira, englobando aproximadamente 200 das cerca de 300 ocorrências de cavernas cadastradas em São Paulo, no Cadastro Nacional de Cavernas, pela SBE - Sociedade Brasileira de Espeleologia (1999).

Associado a esse patrimônio espeleológico está a maior parte dos remanescentes de formações florestais de Mata Atlântica do estado de São Paulo, e por conseqüência essa região apresenta extensas áreas protegidas definidas por Parques, APAs (Áreas de Proteção Ambiental) e Estações Ecológicas Estaduais, sendo reconhecida como Patrimônio da Humanidade pela UNESCO.

Em oposição ao quadro de riqueza natural existente no município de Iporanga estão os índices de avaliação de desenvolvimento econômico e populacional, que mostram uma tendência à estagnação e crescimento populacional negativo, com êxodo rural bastante evidente na observação da evolução histórica dos censos.

A população do municipio de Iporanga foi estimada em aproximadamente 4562 habitantes no ano 2000 (SEADE, 2002), com crescimento negativo de aproximadamente $0,14 \%$ (1991-2000), em uma área de $1200 \mathrm{~km}^{2}$, o que representa uma densidade demográfica de 3,57 habitantes por $\mathrm{km}^{2}$. Apresenta atualmente uma 
economia voltada principalmente para as atividades de turismo, que se concentram no Bairro da Serra, área mais próxima ao Núcleo Santana, do Parque Estadual Turístico do Alto Ribeira (PETAR) e na cidade de Iporanga, que também oferece hospedagem para a grande massa de turistas principalmente em feriados e fins de semana.

\subsection{Justificativa}

A integração de dados utilizando as técnicas de geoprocessamento e sensoriamento remoto permitirá uma avaliação da situação atual do município de Iporanga, que servirá como base na definição de diretrizes de gerenciamento mais adequadas à realidade deste município, que enfrenta dificuldade na busca de desenvolvimento compatível com o elevado grau de restrições ao uso e ocupação encontrados especialmente nessa porção do Vale do Ribeira.

\section{4 Área de Estudo}

O município de Iporanga localiza-se na divisa entre os estados de São Paulo e Paraná, fazendo limite com os municipios de Eldorado, Apiai, Itaoca e Adrianópolis (PR). O acesso à cidade de Iporanga pode ser feito através do percurso São Paulo Apiaí, utilizando-se as estradas estaduais SP-270, SP-127, SP-250, passando pelas cidades de Sorocaba, Itapetininga, Capão Bonito e Guapiara. Seguindo de Apiai utilizase estrada não pavimentada (SP-165) até Iporanga. Outro trajeto pode ser feito através da BR-116, até o município de Registro, seguindo então para Eldorado, que dispõe de estrada pavimentada até Iporanga (Figura 1.1). 


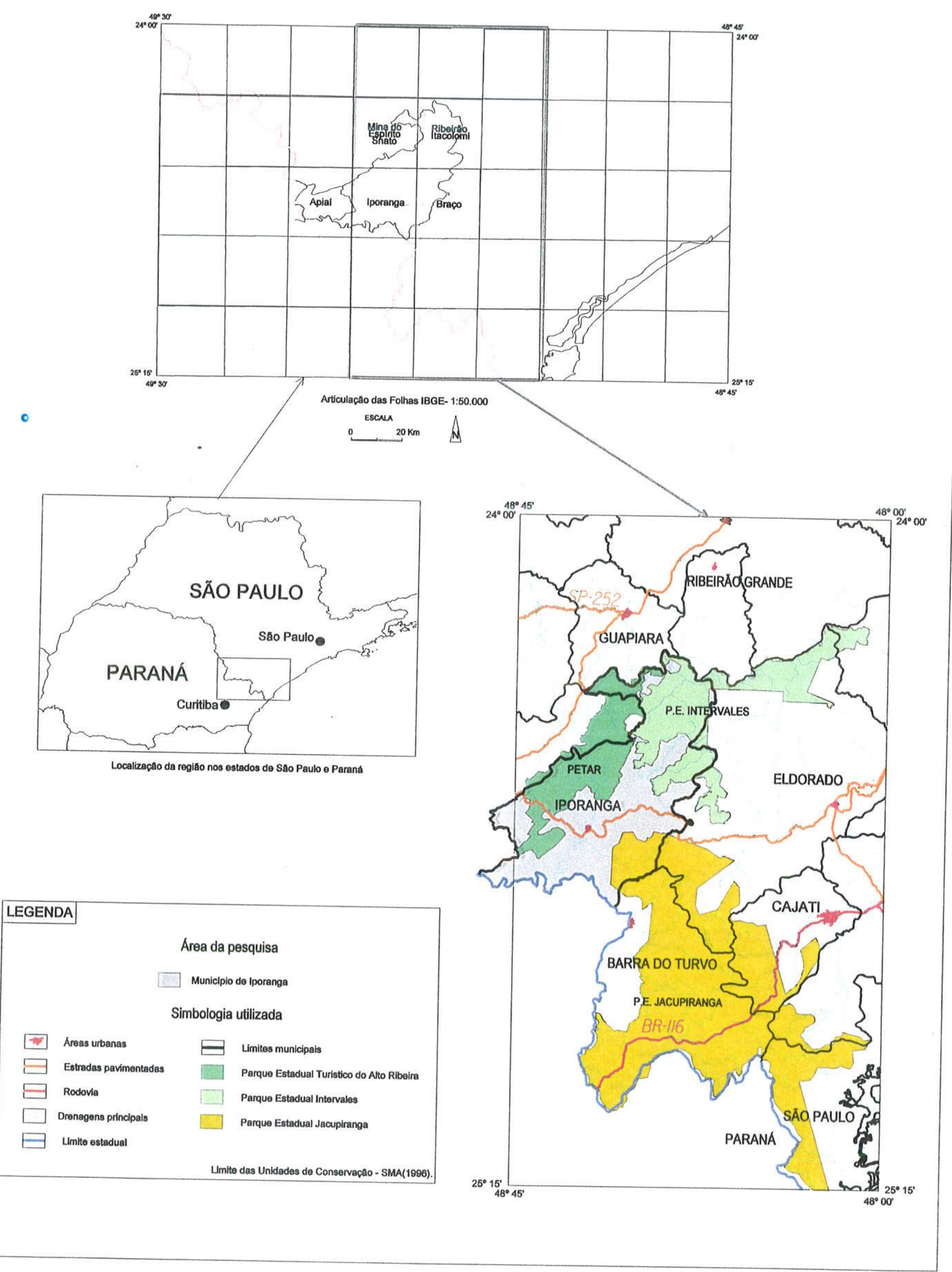

Figura 1-1 - Localização do municipio de Iporanga e principais vias de acesso. 


\section{CAPÍTULO 2-OBJETIVOS}

\subsection{Objetivos gerais}

O objetivo geral deste trabalho é a montagem de um Sistema de Informações Geográficas, visando auxiliar o planejamento territorial do município de Iporanga, levando em consideração o elevado grau de restrições ambientais incidentes na região.

As etapas de trabalho incluem a pesquisa dos métodos de geoprocessamento $\mathrm{e}$ sensoriamento remoto mais adequados ao estudo do uso e ocupação do solo na área relativa ao municipio de Iporanga, analisando as características do meio ambiente, suas relações com as restrições ambientais existentes na região e suas conseqüências para o uso e ocupação do solo.

\subsubsection{Objetivos específicos e atividades realizadas na pesquisa}

Os objetivos específicos propostos foram:

1 - Organizar um banco de dados georreferenciados, referente ao municipio de Iporanga, que possibilite a caracterização do meio ambiente e das formas de ocupaçäo existentes.

As atividades compreenderam o levantamento, conversão e ajuste de dados digitais e analógicos referentes à área, tais como: geológicos, geomorfológicos, pedológicos, aptidão agricola, capacidade de uso, títulos minerários, unidades de conservação, uso e ocupação do solo, obtido com o tratamento de imagens TMLandsat. Esses dados constituem o banco de dados digital do município, em formato original e digital.

2 - Pesquisar as técnicas de análise mais adequadas à caracterização da área frente aos processos de dinâmica superficial.

As atividades incluíram o estudo dos processos de dinâmica superficial mais atuantes na área (movimentos de massa, erosão, subsidência), processamento e combinação dos dados coletados, e geração de cartas de suscetibilidade, que caracterizam os processos segundo os critérios indicados pela bibliografia.

Os produtos gerados foram cartas temáticas originais e derivadas, com respectivos bancos de dados indicando a suscetibilidade natural e a induzida pela ação antrópica.

3 - Pesquisar as técnicas adequadas à caracterização do uso e ocupação do solo no municipio. 
As atividades envolveram o estudo das técnicas de análise de dados de sensoriamento remoto relacionadas ao tratamento de imagens de satélite e extração de informações sobre o tipo de cobertura da terra, incluindo processamento e combinação dos dados produzidos.

Os produtos gerados foram cartas temáticas originais e derivadas, com respectivos bancos de dados indicando a evolução do uso do solo.

4 - Caracterizar áreas com conflitos quanto ao uso do solo nas unidades de conservação no município, descrevendo o tipo de conflito existente.

As atividades incluíram o cruzamento dos mapas temáticos básicos de caracterização do uso do solo, unidades de conservação e atividades mineiras.

Os produtos gerados foram mapas e banco de dados associado, indicando as áreas em conflito para cada tipo de uso.

5 - Avaliar as alternativas de uso e ocupação do solo para o município, considerando os resultados das análises e caracterizações realizadas.

As atividades incluiram a sintetização das informações de evolução do uso do solo, e caracterização das áreas mais aptas aos diversos usos, conforme as características indicadas nas cartas de suscetibilidade, avaliando as alternativas do município considerando o quadro de restrições ambientais.

Os produtos gerados foram mapas e bancos de dados associados indicando as áreas mais aptas aos diversos tipos de uso do solo. 


\section{CAPÍTULO 3 - ASPECTOS GERAIS}

\subsection{Vale do Ribeira}

O rio Ribeira de Iguape constitui a maior bacia hidrográfica paulista a desaguar no Oceano Atlântico, na região estuarino-lagunar do litoral sul, conhecida como Lagamar. Considerando seus principais afluentes, Juquiá e Jacupiranga, abrange uma área de $26310 \mathrm{~km}^{2}$, dos quais $17180 \mathrm{~km}^{2}$ pertencem ao estado de São Paulo, atingindo 23 municípios, totalizando 368.109 habitantes e extensão aproximada de $500 \mathrm{~km}$ (CETEC, 2000).

Essa região constitui uma área singular em relação à conservação das formações florestais da Mata Atlântica no estado de São Paulo, compondo Unidades de Conservação que englobam o continuum ecológico que integra as florestas do norte do estado do Paraná e sul do estado do Rio de Janeiro, configurando a maior mancha de Mata Atlântica preservada no Brasil (Oliva et al., 1999).

Desde quando ocorreram as primeiras entradas no Vale, poucas alternativas de transporte existiam, obrigando quem se dirigia ao planalto, principalmente vindo de Iguape, a utilizar o rio Ribeira, já que era a única via fluvial navegável da região. Posteriormente, com a instalação de núcleos urbanos às suas margens e a necessidade de paradas, Iporanga se destacava, por ser o último porto da porção navegável do Ribeira, no começo dos sertões do Planalto Paulista. As condições de acesso só se modificaram no final da década de $60 \mathrm{com}$ a conclusão da estrada ligando Iporanga ao Baixo Vale (Figueiredo, 2000).

O desenvolvimento do Vale do Ribeira pode ser associado a três ciclos: o início do século XIX marca o final do primeiro ciclo econômico do Vale do Ribeira, que se estruturou na busca de ouro, favorecendo a formação de outras povoações ribeirinhas, além do Arraial de Santo Antônio (Iporanga), tais como: Ivaporunduva, Jaguary (Itapeúna) e Xiririca (Eldorado); o segundo ciclo econômico, que se inicia na metade do século XIX, e relaciona-se com a retomada de atividades econômicas, em localidades que se apresentavam em franca decadência, em torno da agricultura da cana-de-açúcar, da mandioca, e principalmente, do arroz, além de outros produtos de subsistência, associado à descoberta de chumbo/prata na região de Iporanga; e o terceiro ciclo econômico que teve início na metade do século XX e perdura até hoje, baseado em atividades agrícolas relacionadas ao cultivo de banana e chá (Figueiredo, 2000). 


\subsubsection{Histórico da ocupação do Vale do Ribeira}

Petrone (1966) ${ }^{1}$ descreve o histórico da ocupação da Baixada do Ribeira, destacando como o próprio nome ressalta as áreas baixas do Vale, o Baixo Vale, abrangendo do litoral até Iporanga. Os principais processos de povoamento no litoral decorreram até o início do século XVII, estando sempre ligados ao mar com atividades de subsistência (lavoura) e pesca. A tentativa de fixação de europeus limitava-se às ilhas, principalmente na região de Iguape, seguindo-se llha Comprida, Cananéia e ltha do Cardoso

A partir de meados do século XVII, partiam de Iguape freqüentes incursões para o interior, tendo como objetivo principal a busca de jazimentos de ouro, o que levou a entrada Ribeira acima, penetrando a montante de muitos de seus afluentes e subafluentes. O ouro encontrado tratava-se de ouro aluvionar resultante de processos de erosão, transporte e deposição do metal contido em rochas da região. Esses depósitos ocorrem de forma irregular ao longo dos rios da região. Diversos afluentes do rio Ribeira em Apiai, Iporanga, Sete Barras e Eldorado foram minerados, sendo que a região de Xiririca (atual Eldorado) foi o principal ponto explorado.

Com a descoberta dos jazimentos compensadores, as atividades dos habitantes se estenderam para o interior, no decorrer do século XVIII. As descobertas para o interior haviam atingido Apiaí, cuja elevação à Vila data de 1770

Os moradores de Iguape se deslocavam para essas regiões permanecendo às margens do rio Jaguari, próximo ao rio Xiririca. A mineração era a atividade principal de todos os moradores das margens do Ribeira. A produção de ouro bateado Ribeira acima convergia para Iguape, onde se instalou uma casa de fundição.

Iguape teve destaque como 'cabeça' regional, atuando como base para formação dos primeiros embriões de cidades da retro-terra (terras de cultivo), permitindo a criação de vitalidade econômica para a região e ampliação do conhecimento das terras ribeirinhas (apesar de não contribuir para a criação de uma atividade agrícola que justificasse enraizamento mais significativo da população).

Posteriormente foi criado o porto de Registro que, como o próprio nome indica, era o local destinado ao controle da produção de ouro rio acima, para efeito do pagamento dos quintos reais.

\footnotetext{
${ }^{1}$ Petrone (1966) deve ser considerada a principal referência utilizada, na elaboração do texto deste item, excluindo-se partes do texto atribuidas a outros autores, devidamente citadas.
} 
As relações com as jazidas de Iporanga e Apiaí permitiram que se esboçassem os primeiros contatos com relativa freqüência em direção ao planalto. $O$ interesse no controle das atividades de mineração, entretanto, fizeram com que a administração não permitisse a abertura de caminhos que poderiam dificultar o controle do fluxo e a cobrança dos direitos às mercadorias a isso sujeitas, sendo o controle pela passagem do Ribeira mais cômodo. As atividades agrícolas nesse periodo eram limitadas a culturas de subsistência em um sistema de roças.

A partir da segunda metade do século XVIII, a lavoura sofreu incrementos e teve condição de exportar o excedente produzido, surgindo nessa época, na cidade de Cananéia, importante porto de embarque de mercadorias (excedentes da produção de farinha de mandioca e arroz) para outras regiões (Santos, Santa Catarina, Rio de Janeiro e Rio Grande do Sul). Nesta época a mineração estava em franco declínio, devido à escassez de minérios, falta de incentivos e de tecnologia de mineração.

No início do século XIX as atividades ligadas à construção de barcos tiveram um incremento, especialmente em Cananéia, onde parte da população que se dedicava à agricultura passava por dificuldades, pois seus produtos não encontravam mercados consumidores, apesar das super-produções.

A chegada dos imigrantes ocorreu a partir de 1861 quando foram criadas as primeiras colônias na tentativa de atrair imigrantes estrangeiros e nacionais para a área, com pouco impacto para a região do Alto Vale, estando muito presente nas outras regiões do Baixo Vale, que apresentavam maior aptidão para atividades agrícolas (Registro, Pariqüera-Açu, entre outros).

A cultura de café foi instituida com o declinio da mandioca e do arroz, pelos grandes fazendeiros, que tentaram implantar a produção de cafés finos, com grande investimento em infra-estrutura. A produção não durou mais do que 50 anos, devido ao deslocamento do cultivo de café principalmente para a região do Vale do Paraiba, e a quebra da bolsa de Nova lorque em 1929, que afetou o comércio internacional.

Ainda no início do século XX existia uma grande precariedade das vias de comunicação e transporte, estando a região praticamente à parte do sistema ferroviário, sendo que grande parte dos fluxos ainda era feita através do sistema fluvia! do Ribeira de Iguape que não podia servir toda a área povoada.

A ferrovia Santos-Juquiá foi construida apenas em 1914, e auxiliou no deslocamento do eixo econômico da região para o centro e o norte, permitindo o intercâmbio com Santos e São Paulo. Foi também nessa época que surgiram as primeiras rodovias ligando os principais núcleos da região, e a estrada de ligação com o ramal ferroviário (Registro-Juquiá). 
A partir de 1940 surge um segundo período de investimentos em fazendas que visavam o mercado em expansão para as culturas de banana e chá em toda a região do Baixo Vale.

A mineração encerrou no início do século XVIII o "ciclo do ouro" na região, tendo uma pequena retomada somente no final do século XIX com a abertura da mina subterrânea do Morro do Ouro em Apiaí.

A ocorrência de prata levou a tentativas de mineração desde a metade do século XIX, iniciando-se a produção organizada na Mina de Furnas em 1919 quando teve início o "ciclo do chumbo-prata" na regiäo (minas de Furnas, Panelas, Rocha, Canoas, Perau, entre outras) com paralisação em 1996. Atualmente as atividades de mineração na região estão restritas à procura de minerais não metálicos, principalmente calcários e dolomitos, que teve início nos anos 50 (Shimada, 1999).

\subsubsection{História de Iporanga}

A ocorrência de muitos sítios arqueológicos (Barreto, 1988; De Blasis, 1988, apud Godoy, 2001) indica que a presença de populações humanas pré-coloniais, na região do alto Ribeira, é muito antiga, sugerindo idades de até 10000 anos, e caracterizando grupos ligados à caça, pesca e coleta.

Figueiredo (2000) apresenta um histórico da cidade de lporanga baseando-se em diversos autores (Carril, 1995, Krug, 1908, 1913 e 1939, Calógeras, 1904-1905, Guimarães, 1981 e Nestlehner, 1979), destacando a importância histórica da cidade no quadro nacional, quando ocorreram os primeiros ciclos de expansão geográfica do Brasil colonial que, associado ao patrimônio arquitetônico ainda existente, resultaram no tombamento do núcleo histórico da cidade.

Entre os diversos trabalhos consultados, o autor destaca a pequena documentação existente e algumas divergências e contradições, encontradas principalmente em relação aos primeiros registros de expedições na região em busca de ouro.

\subsubsection{O Cicio do Ouro}

A primeira expedição à região em busca de ouro data de 1531 (Burton, 1869, Barbosa e Guimarães, 1946, apud Shimada 1999). Essa expedição teria sido ordenada por Martim Afonso de Souza para comprovar as informações de um antigo morador de Cananéia sobre a existência de ricas minas de ouro no interior, subindo o rio Ribeira de Iguape. 
Figueiredo (2000) ressalta que existem controvérsias sobre o que realmente aconteceu com esse grupo, sendo usualmente citada a opinião de que teriam sido aniquilados pelos índios Carijós, não havendo referência sobre descoberta de ouro pela mesma.

Diversas expedições foram planejadas pelo então governador-geral Mem de Sá, encarregando Brás Cubas (fundador de Santos, na época provedor da Capitania de São Vicente) e Luis Martins (mineiro nomeado), de verificarem a veracidade de alguns descobrimentos anônimos. Brás Cubas dirigiu a primeira expedição em 1560, até 1561, obtendo bons resultados e percorrendo cerca de $2000 \mathrm{~km}$. Luís Martins dirigiu a segunda expedição, encontrando ouro de excelente qualidade a cerca de $200 \mathrm{~km}$ de Santos. Em ambas expedições é provável que tenham tomado um rumo oposto ao previsto, que era para a região do São Francisco, citando achados na região de Apiaí (Figueiredo, 2000).

Outras descobertas foram feitas no período de 1570 a 1584 , na região de Iguape, Paranaguá e nos campos de Curitiba, em áreas acima da Serra do Mar. No periodo de 1635, a Casa Real de Fundição já estava em funcionamento na vila de Nossa Senhora das Neves (Iguape), sendo explorado ouro em toda a região do Vale do Ribeira.

Outros registros de expedições datam de 1675 quando Manuel Pereira Sardinha teria tomado o rumo dos sertões de Paranaguá e do Ribeira de Iguape, sendo considerado que a mesma coincidiu com a descoberta das mais importantes minas de ouro de lavagem do atual estado do Paraná (Calógeras, 1904-1905, apud Figueiredo, 2000).

Apesar das descobertas e da tentativa de aumentar o número de minas na região, segundo Guimarães (1981, apud Figueiredo, 2000), a produção de ouro era bem fraca neste periodo, que pode ser o reflexo das inúmeras dificuldades e falta de incentivos à exploração mineral, que competia com a cultura canavieira, também em uma fase de recessão no final do século XVII, causada, entre outros fatores, pela queda de preços do açúcar no mercado internacional (Figueiredo, 2000).

O Ciclo do Ouro concretizou-se somente no século XVIII, após a descoberta de ouro em Minas Gerais, no final do século XVII. Nessa época, Iporanga apresentava uma produção inexpressiva perante o quadro nacional, sendo que o produto do garimpo teria sido suficiente para manter o povoado e condições para o desenvolvimento.

O Arraial de Santo Antônio de Iporanga, fundado em aproximadamente 1576, localizado a $7 \mathrm{~km}$ da foz do rio lporanga, foi progressivamente abandonado com o fim 
da atividade mineira. Seus moradores passaram a ocupar um novo local, na confluência com o ribeirão Iporanga (área urbana atual do município) ${ }^{2}$.

Outro motivo atribuido para essa mudança, além do esgotamento do ouro, está relacionado ao assoreamento do rio Iporanga provocado pela remoção excessiva de material estéril dos depósitos aluvionares. O ouro, por apresentar elevada densidade, geralmente se concentra na base do depósito aluvionar, que apresenta uma sucessão de camadas de argila, areia fina, areia média, areia grossa e cascalho, do topo para a base (Shimada, 1999), o que exige a remoção de toda a seqüência estéril acima da mesma para a sua extração.

O assoreamento teria contribuído para a mudança do núcleo populacional por dificultar as atividades de transporte e navegação ao longo do rio lporanga. As atividades dos moradores se intensificaram na agricultura, principalmente de arroz, cujos excedentes eram transportados para a Vila de Iguape.

Em 1802 chega ao povoado o padre Bernardo de Moura Prado, primeiro vigário a fixar residência na cidade, dando início a um movimento oficial para a construção de uma nova capela onde já estava instalada a maioria dos moradores, na barra do ribeirão Iporanga. O início das obras da capela, em taipa de pilão (construção empregando barro socado com piläo), data de 1815, e sua conclusão em 1821.

A maioria dos moradores do povoado encontrava-se na zona rural, estando vinculados ao vilarejo apenas para a compra de materiais de primeira necessidade. Em 1830 o povoado foi elevado a categoria de freguesia, em uma época de relativa fartura e riqueza, mesmo com o esgotamento do ouro. Nessa época Iporanga servia de entreposto, interligando a Baixada do Ribeira e o planalto de Apiaí, baseando sua economia na agricultura, pequena indústria de transformação e atividades comerciais. Em 1843, Iporanga foi transferida do município de Apiaí para o de Xiririca (Eldorado), iniciando o processo de emancipação político-administrativa (Figueiredo, 2000).

\subsubsection{O Ciclo do Chumbo/Prata}

Na segunda metade do século XIX são retomadas as atividades de mineração em lporanga com a descoberta de grandes jazidas de galena argentífera, minério de chumbo com alto teor de prata. Essas jazidas foram oficialmente descobertas em 1857 ,

\footnotetext{
${ }^{2} \mathrm{O}$ rio Iporanga é um afluente do Ribeirão Iporanga que por sua vez é um afluente da margem esquerda do rio Ribeira.
} 
pelo engenheiro francês Luiz D'Ordan, mas até 1891 não tinham sido exploradas, conforme relatado por Henrique Bauer (Figueiredo, 2000).

Iporanga estava consolidada como um entreposto comercial abastecendo os viajantes que se dirigiam para Xiririca (Eldorado) e ao planalto, seguindo principalmente para Apiaí, Faxinal (Itapeva), São José do Paranapanema (Guapiara), Capão Bonito e Itapetininga (Figueiredo, 2000).

Em 1866, com a Guerra do Paraguai, ocorreu uma tentativa de desenvolvimento de algodão na agricultura, que tradicionalmente era voltada para o arroz e cana-deaçúcar. Contudo, essa cultura agrícola não foi bem sucedida devido às dificuldades de transporte e ausência de melhores incentivos governamentais.

As condições cada vez mais promissoras, em relação ao estabelecimento de atividades de mineração do chumbo-prata, e o crescimento da agricultura fortaleceram o movimento de elevação de Iporanga para a categoria de Vila, que ocorreu em abril de 1873. O rápido crescimento da Villa de Sant'Anna de Yporanga levou à instalação do município de Iporanga em 12 de janeiro de 1874. No ano de 1875, Godoy (1978, apud Fiqueiredo, 2000) apontou uma população de 3.000 habitantes.

Leonardos (1934) e Barbosa e Guimarães (1946 apud Shimada, 1999) destacam que o engenheiro Henrique Bauer foi quem primeiro examinou as mineralizações plumbíferas do Morro do Chumbo, do Espírito Santo e do sítio da Boa Vista, chamando a atenção sobre as mesmas, o que resultou em vários decretos autorizando a exploração das mineralizações (Tabela 3.1).

Tabela 3.1 - Concessões imperiais de mineração na região do PETAR.

\begin{tabular}{|c|c|}
\hline Decreto / data & \multicolumn{1}{|c|}{ Natureza } \\
\hline 2.297 de $30 / 10 / 1858$ & $\begin{array}{l}\text { Concede permissão a Luiz d'Ordan para explorar chumbo em } \\
\text { lporanga, no Morro do Chumbo. }\end{array}$ \\
\hline 3.300 de 20/08/1864 & $\begin{array}{l}\text { Concede permissão a João Antonio de Miranda e Silva para explorar } \\
\text { chumbo, estanho e outros metais na serra de Iporanga. }\end{array}$ \\
\hline 3.706 de 26/09/1866 & $\begin{array}{l}\text { Autoriza Richard F. Burton e Augusto Teixeira Coimbra a explorar } \\
\text { chumbo, estanho e outros metais nas terras de lporanga. }\end{array}$ \\
\hline 5.265 de 29/05/1871 & $\begin{array}{l}\text { Angelo Tomaz do Amaral e Antonio Cândido da Rocha para explorar } \\
\text { chumbo, petróleo e outros minerais em Iporanga. }\end{array}$ \\
\hline 9.223 de 31/05/1884 de 27/11/1872 & $\begin{array}{l}\text { Permite a João Paulo Dias lavrar ouro, chumbo, ferro e outros } \\
\text { minerais no municipio de Apiaí. }\end{array}$ \\
\hline Fonte: Leonardos (1934) e Barbosa e Guimarães (1946, apud Shimada, 1999). \\
\hline $\begin{array}{l}\text { Autoriza Pedro da Silva Pereira e Manuel J. Borges de Lima a } \\
\text { Xxplorar chumbo e outros minerais na serra do Etá, da comarca de } \\
\text { Xiririca (antigo nome de Eldorado). }\end{array}$ \\
\hline
\end{tabular}

Shimada (1999) descreve alguns eventos importantes nas pesquisas das mineralizações de chumbo-prata da região, citando as áreas do Morro do Chumbo, Moitinho, São Domingos e Braço da Pescaria, no período de 1850 até 1900. 
No início do século $X X$ a região foi objeto de expedições da Comissão Geográfica e Geológica do Estado de São Paulo, que concluiu, em seus estudos cartográficos e científicos, que a região de Iporanga tinha potencial para se desenvolver através do aproveitamento de suas riquezas minerais, desde que fosse dotada de infra-estrutura de transporte (CGG 1914, apud Shimada, 1999).

A mineração de chumbo-prata na região foi iniciada somente em 1919, na jazida de Furnas, que havia sido descoberta e manifestada no ano anterior pelo então proprietário, Manoel Ribeiro Neto. Em 1925, o engenheiro Theodoro Knecht assumiu a direção da mina, localizando outras mineralizações.

O minério de Furnas, após seleção manual, era transportado até Iporanga, de onde era embarcado rumo ao litoral, seguindo então para a Espanha, onde era processado na Sociedad Peñarroya. O minério era essencialmente composto por galena, com até $75 \%$ de chumbo e 2,6 a $3,4 \mathrm{~kg}$ de prata por tonelada (Shimada, 1999).

Furnas produziu, de forma intermitente, minério de chumbo rico em prata e como subproduto, o minério de zinco (esfalerita - ZnS), tendo seu último período de funcionamento de 1979 ao início de 1992, quando paralisou suas atividades por razões econômicas. Duas empresas administraram Furnas nesse periodo: a CAF-Argentifera Furnas, entre 1979 e 1989, quando o controle foi vendido à Plumbum Mineração e Metalurgia S.A. - Grupo Trevo, que já fundia o minério em sua usina de Panelas. Entre os fatores complicadores das atividades na mina estavam: o grande volume de água vindo das fraturas, com vazão total aproximada de $150 \mathrm{~m}^{3} /$ hora, obrigando o bombeamento permanente; a forma irregular dos filões, que não permitia o emprego de mecanização; e o baixo teor do minério, resultando no fechamento da mina (Shimada, 1999).

No Alto Ribeira, do lado paranaense, foram encontradas, a partir de 1920 , jazidas de chumbo-zinco-prata volumetricamente mais expressivas, viabilizando operações mínero-metalúrgicas a longo prazo, como as minas de Panelas, Rocha e Perau (Daitx, 1996 e Souza, 1972, apud Shimada, 1999).

A primeira instalação de uma metalurgia de chumbo na região, e no Brasil, teve início em 1934, pela Companhia de Mineração Iporanga, também concessionária das jazidas do Morro do Chumbo e do Monjolinho. Foram fundidas apenas 5 toneladas de chumbo durante o período em que operou o forno, a partir de minérios procedentes dos filões Moitinho, São Domingos e Monjolinho, contendo teor médio de $27 \%$ e $0,8 \mathrm{~kg}$ de prata por tonelada de chumbo (Barbosa e Guimarães 1946, apud Shimada 1999). 
Figueiredo (2000) relata que no ano de 1937 Iporanga foi afetada por uma das maiores enchentes que assolou a região do Vale do Ribeira, fazendo com que o rio Ribeira se elevasse 11 metros (em Iporanga), causando danos irreparáveis à agricultura e à criação de suínos, deixando muitas pessoas desabrigadas. Entre outros problemas de instabilidade econômica e com a epidemia de malária, que atingiu a região no ano seguinte à enchente, os moradores começaram a abandonar a cidade utilizando a estrada recentemente construída, que ligava Iporanga à Apiaí, em busca de melhores condições de moradia e trabalho.

O progresso esperado com a construção da estrada de ligação à Iporanga dá lugar ao início do processo de esvaziamento da cidade, favorecido por uma série de más administrações municipais (Ferraz, 1945, apud Figueiredo, 2000), e no mesmo período ocorre a incorporação do distrito de Barra do Turvo ao distrito sede de Iporanga.

Em 1939 foi aberta pela Plumbum S.A. a mina de Panelas, em Adrianópolis, Paraná, mina de maior duração na região, tendo operado continuamente até o início de 1988 (Zaccarelli, 1988, apud Shimada, 1999).

Em 1940 foi inaugurada em Apiaí a Usina de Chumbo e Prata do Instituto de Pesquisas Tecnológicas - IPT, projetada pelo engenheiro Tarcísio Dami de Souza Santos, com capacidade inicial de produzir 10 toneladas/dia de chumbo refinado (Barbosa e Guimarães 1946, apud Shimada, 1999), fechando em 1945, não mais voltando a funcionar.

Nesse mesmo período, concomitantemente à mineração, uma nova alternativa econômica é encontrada, a indústria extrativista vegetal, tendo como produto principal o palmito. A instalação da primeira fábrica ocorreu na Fazenda Santana, próxima ao Bairro Pilões.

Em 1945 a Plumbum S.A., então controlada pelo Grupo Peñarroya, inaugurou ao lado da mina de Panelas a sua usina metalúrgica, que passou a processar também os minérios provenientes de várias outras minas da região, como Rocha, Barrinha, Perau, Berta do Leão, Furnas e Lajeado. Algumas minas, como Furnas, produziram também minério de zinco que, após concentração, era vendido a terceiros interessados no seu refino. Os minérios de chumbo continham, usualmente, além da prata, pequenas quantidades de ouro, da ordem de $0,5 \mathrm{~g} / \mathrm{t}$, recuperado no processo metalúrgico da usina de Panelas (Shimada, 1999).

O final da década de 50 é marcado pelo declinio da mineração de chumbo na região de lporanga. Por outro lado, ocorre o fortalecimento de um movimento de 
pressão política para a criação de um parque florestal do estado para a proteção das cavernas da região, o que ocorreu em 1958, com a criação do PETAR (Parque Estadual Turistico do Alto Ribeira).

Após um período de estagnação econômica, agravado pela própria situação do país com inflação e crise econômica, ocorreu a emancipação política de Barra do Turvo, em 1964, ocorrendo um grande êxodo da população de Iporanga, parte para o novo município que estava crescendo, e parte para grandes cidades, com destaque para a região do $A B C$ e da capital paulista.

No período de 1968 à 1971 ocorreu uma série de melhorias em Iporanga, como a estrada ligando ao município de Eldorado e a ponte sobre o rio Ribeira, que acabou com o isolamento da cidade e facilitou sua comunicação com a região de Registro. Esse processo de melhoria estava, em parte, ligado à existência de um movimento de guerrilha, contrário a política implantada pelos governos militares, organizado pelo capitão Carlos Lamarca, que esteve na região nesse período (José e Miranda, 1989 e Martinez, 1995, apud Figueiredo, 2000).

A passagem para a década de 80 marcou uma mudança no quadro de atividades econômicas. Na década de 70 manteve-se a política assistencialista, ocorrendo a elaboração de várias propostas para o aproveitamento turístico e proteção do patrimônio histórico-cultural. No final da década de 70 ocorreu a reativação da mineração de chumbo e prata pela CAF - Companhia Argentífera Furnas. Ocorreu ainda nessa época uma reativação das fábricas de palmito, serrarias, madeireiras e outras atividades extrativistas que, por serem realizadas de forma predatória, acabaram levando à conflitos com a questão da conservação do meio ambiente (Figueiredo, 2000).

O problema da falta de títulos de propriedade das terras acentuou os conflitos, no início da década de 80 , com o início dos processos de implantação do PETAR e o tombamento da cidade.

Shimada (1999) apresenta um levantamento (Tabela 3.2) das principais descobertas dos anos 70, 80 e inicio dos 90, quando várias empresas, entre elas a CPRM, CVRD, MINEROPAR, DUPONT, RHODIA, UNIGEO, Plumbum Mineração e Metalurgia S.A. e o IPT, realizaram intensas campanhas de prospecção mineral na região do Alto Vale do Ribeira. O resultado dos dados levantados indica a descoberta de depósitos minerais metálicos e não metálicos. Contudo, nenhum desses pode ser incluído na categoria de grandes depósitos, o que caracteriza a vocação da região para acumulações minerais principalmente de pequeno porte, e algumas de médio porte. 
Isto compromete a rentabilidade da exploração de depósitos na região, segundo o mesmo autor, quando é feita uma comparação com outras minerações do exterior, em que grandes minas são operadas, com reduzido custo unitário de produção.

Os depósitos de rochas carbonáticas constituem exceção a essa regra, ocorrendo sob a forma de massas rochosas que atingem dezenas a centenas de milhões de toneladas, permitindo operações mineiras a longo prazo e em grande escala, na casa dos milhões de toneladas de rochas extraidas anualmente (Shimada, 1999).

Tabela 3.2 - Relação das descobertas minerais no Alto Ribeira no período de 1970 a 1995.

\begin{tabular}{|c|c|c|c|}
\hline $\begin{array}{l}\text { (1) Jazida } \\
\text { (2) Depósito }\end{array}$ & Substância(s) & Localização & Empresa / Referência bibliográfica \\
\hline $\begin{array}{l}\text { Canoas } 1(1) \\
\text { (exaurida) }\end{array}$ & $\begin{array}{c}\text { Chumbo, zinco, } \\
\text { prata }\end{array}$ & Adrianópolis, PR & $\begin{array}{l}\text { Plumbum Mineraçāo e Metalurgia S.A. I } \\
\text { (Daitx, 1996) }\end{array}$ \\
\hline $\begin{array}{l}\text { Canoas } 2(1) \\
\text { (exaurida) }\end{array}$ & $\begin{array}{c}\text { Chumbo, zinco, } \\
\text { prata }\end{array}$ & Adrianópolis, PR & $\begin{array}{l}\text { Plumbum Mineração e Metalurgia S.A. / } \\
\text { (Daitx, 1996) }\end{array}$ \\
\hline Canoas $3(2)$ & $\begin{array}{l}\text { Chumbo, zinco, } \\
\text { prata }\end{array}$ & Adrianópolis, PR & $\begin{array}{c}\text { Plumbum Mineração e Metalurgia S.A.f } \\
\text { (Daitx, 1996) }\end{array}$ \\
\hline Araçazeiro (2) & $\begin{array}{l}\text { Chumbo, zinco, } \\
\text { prata }\end{array}$ & Adrianópolis, PR & $\begin{array}{l}\text { UNIGEO } \\
\text { (Anglo American) }\end{array}$ \\
\hline $\begin{array}{l}\text { São Sebastião (2) } \\
\text { (paralisada) }\end{array}$ & Fluorita & Adrianópolis, PR & $\begin{array}{c}\text { GEOS-Consultoria (vendida à CBA-Grupo } \\
\text { Votorantim) }\end{array}$ \\
\hline $\begin{array}{l}\text { Mato Preto (1) } \\
\text { (mina ativa) }\end{array}$ & Fluorita & Cerro Azul, PR & Dupont \\
\hline $\begin{array}{l}\text { Volta Grande (1) } \\
\text { (mina ativa) }\end{array}$ & Fluorita & Cerro Azul, PR & MINEROPAR \\
\hline Apiai (2) & Fluorita & Apiai, SP & Camargo Correa Industrial S.A. \\
\hline Barra do Itapirapuã (2) & Terras Raras & Itapirapuã, SP & Canopus Mineração Ltda. (Grupo Rhodia) \\
\hline Itaóca (2) & $\begin{array}{l}\text { Tungstênio e } \\
\text { Wollastonita }\end{array}$ & Itaóca, SP & IPT/(Pressinotti, 1992 e Melo, 1995) \\
\hline Piririca (2) & Ouro & Iporanga, SP & $\begin{array}{c}\text { CPRM/(Morgental et al. 1981, Borin et al. } \\
\text { 1980, DNPM/CPRM, 1982, CPRM, 1986, } \\
\text { Nogueira, 1990) }\end{array}$ \\
\hline Correas (2) & Estanho & $\begin{array}{l}\text { Ribeirão Branco, } \\
\text { SP }\end{array}$ & $\begin{array}{c}\text { IPT (vendida ao Grupo Paranapanema) } \\
\text { (Goraieb, 1995) }\end{array}$ \\
\hline
\end{tabular}

Fonte: Shimada (1999).

O termo jazida mineral indica a existência de uma concentração mineral passível de ser aproveitada economicamente, nas condições atuais de mercado. O termo depósito mineral expressa a existência de acumulações minerais em quantidade suficiente para indicar um potencial mineral econômico, que conforme a concentração existente no depósito (teor) podem ser extraídas de forma economicamente viável (com lucro).

Atualmente, não há minas de chumbo em operação na região ou no Brasil, sendo o País dependente de importações de chumbo de primeira fusão. As necessidades são complementadas por chumbo de segunda fusão, reciclado a partir de sucata de baterias. Shimada (1999) afirma ainda que estudos encontram-se em 
andamento na área da mina de Furnas e que um grupo empresarial estuda a reabertura da usina metalúrgica da Plumbum Mineração e Metalurgia S.A.

\subsection{0 município de Iporanga}

O município de Iporanga apresenta uma população aproximada de 4562 habitantes no ano 2000, com crescimento negativo de aproximadamente $0,14 \%$ (período 1991-2000), e uma área de $1200 \mathrm{~km}^{2}$.

A economia do município apresenta-se voltada principalmente para as atividades de turismo, estando concentradas no Bairro da Serra, área mais próxima ao Núcleo Santana (PETAR), e na própria cidade de lporanga, que também oferece hospedagem para a grande massa de turistas, principalmente em feriados e fins de semana.

A precariedade das estradas de acesso constitui um dos fatores que historicamente vem isolando a região devido às quedas de barreiras, principalmente no período mais chuvoso (novembro a março).

Os trechos mais críticos são aqueles sem pavimentação, e parte das rodovias pavimentadas nas áreas próximas ao rio Ribeira, que apresentam movimentação de terra e estreitamento de pista. Dois trajetos podem ser utilizados, o primeiro seguindo pela BR-116, a partir de São Paulo, totalizando $352 \mathrm{~km}$, com trechos críticos entre Eldorado e Iporanga; o segundo via Castelo Branco (SP-270) totalizando $335 \mathrm{~km}$, com trecho de $34 \mathrm{~km}$ de rodovia não pavimentada, praticamente intransponível no período mais chuvoso.

A duplicação da Rodovia Régis Bittencourt (BR-116), ainda em andamento, propicia o aumento potencial do fluxo de turistas, e conseqüentemente da expansão e melhoria das estruturas de apoio às atividades de turismo no município.

Os principais núcleos de visitação em Iporanga estão localizados no interior do PETAR (Parque Estadual Turístico do Alto Ribeira): núcleo Santana, próximo ao Bairro da Serra, e o núcleo Caboclos (que localiza-se no município de Apiaí). Outros núcleos de visitação são Ouro Grosso e Casa de Pedra, próximos à área urbana.

Esses núcleos de visitação disponibilizam somente parte das cavernas da região, em função da dificuldade de acesso e penetração, existência de pesquisas, e fragilidade do ambiente subterrâneo.

Algumas cavernas, como a de Santana, que recebem grande número de visitantes, apresentam alguns salões fechados aos turistas. Outras cavernas, que apresentam fácil acesso, são totalmente fechadas com grades impedindo a entrada. $O$ controle da entrada nessas cavernas, em sua maior parte, é feito pela administração do 
núcleo, que guarda as chaves de cada local, limita a freqüência das visitas e número de pesquisadores.

No Vale do Ribeira, a principal atividade econômica é a agricultura, em que se destacam as culturas de chá e banana, em extensão cultivada e importância comercial. Contudo, essas produções apresentam problemas quanto a limitações estruturais que impedem a expansão e modernização da produção (CETEC, 2000). Entre os problemas enfrentados pelos produtores os mais preocupantes são o baixo preço do produto no mercado, e as dificuldades de aceitação no mercado externo, devido a qualidade inferior dos produtos em relação aos oferecidos por outros países.

No municipio de Iporanga, a cultura da banana, que é produzida em praticamente todos os municípios do Vale, apresenta áreas mais expressivas de cultivo localizadas na margem direita do Ribeira, próximo ao limite com o município de Eldorado. As demais áreas de cultivo encontradas constituem pequenas parcelas espalhadas nas propriedades rurais, não caracterizando o município como um grande produtor.

As atividades agricolas em Iporanga estão associadas a pequenas propriedades rurais em que se desenvolvem áreas de cultivo, geralmente de pequeno porte e atividades de pecuária.

As características naturais da região, associadas ao crescente interesse na conservação dos recursos naturais existentes, têm favorecido o investimento nas atividades relacionadas ao turismo, e atividades capazes de gerar renda sem conflitos com a conservação do meio ambiente.

O CETEC (2000) indica um forte crescimento do setor de turismo no Vale do Ribeira e inclui a piscicultura como uma alternativa, por possibilitar condições de desenvolvimento sem grandes impactos negativos.

A Tabela 3.3 apresenta o quadro de evolução da demografia do município segundo dados do ano 2000 da fundação SEADE (2002). Em relação à concentração populacional na área urbana, Iporanga apresentou no periodo de 1980 até 2000 um significativo aumento da população urbana, associado à uma forte diminuição no contingente de população das áreas rurais. Esse aumento relaciona-se principalmente ao declinio das atividades econômicas no município, acentuadas a partir da década de 80 com o declínio das atividades de mineração e a intensificação dos problemas fundiários associados à implantação do PETAR e do tombamento da cidade de Iporanga como patrimônio histórico.

Com a intensificação desses confilitos, na década de 80 , parte do contingente populacional rural passou a migrar para a área urbana e, de forma geral, passaram a 
emigrar para outros municípios, como Apiai, Barra do Turvo, Itaoca e principalmente cidades maiores como Registro, Sorocaba e São Paulo (Hogan, 2000). Tal fato é confirmado pela queda na população total do município nos últimos anos, apresentada na Tabela 3.3.

A fundação SEADE (2002) apresenta no Perfil Municipal de Iporanga uma relação dos estabelecimentos cadastrados no Ministério do Trabalho, indicando um total de 19 estabelecimentos, que empregam 210 pessoas, das quais 187 estão vinculadas a estabelecimentos do setor de serviços.

No entanto, essas estimativas de trabalhadores formais (estrutura ocupacional) é dada pela Relação Anual de Informações Sociais - RAIS, do Ministério do trabalho, mostrando somente o número de trabalhadores assalariados com carteira de trabalho assinada, na indústria, no comércio, em serviços e em outras atividades não especificadas, não expressando portanto o real mercado de trabalho, por não incluir o trabalho sem carteira, ou o mercado informal.

Esses números indicam uma importância considerável do setor de serviços para o município, associada a uma elevada quantidade de trabalhadores informais, em sua maioria vinculados às atividades de turismo.

Em relação à política de planejamento, o levantamento realizado pelo CETEC (2000) indicou a existência em Iporanga da Lei Orgânica do Município, que inclui referências às questões ambientais, mas nenhum dispositivo legal de controle ambiental ou legislação de proteção. No Vale do Ribeira, apenas o municipio de Jacupiranga possui Plano Diretor, estando o de Apiai em fase de preparação.

A fundação SEADE (2002) classificou o municipio de Iporanga, segundo o índice Paulista de Responsabilidade Social (1992-1997) como pertencente ao grupo 4, de baixo desenvolvimento econômico e em transição social. Esse índice é obtido a partir de indicadores sintéticos de riqueza, longevidade e escolaridade. No caso de Iporanga, indica que apesar do baixo nivel de riqueza, o município teve um significativo avanço em alguns campos da área social, particularmente no caso do indicador de longevidade. Contudo, esse indice indica uma sensivel carência na área de educação, confirmada com a taxa de analfabetismo de $19,11 \%$, enquanto no estado de São Paulo a taxa média é $6,64 \%$.

As atividades da atual gestão (Prefeito Jamil Adib Antonio - PTB) foram constatadas em visitas de campo (período de fevereiro de 2002), consistindo no início de uma série de obras de infraestrutura, como reconstrução de pontes, retificação das estradas, instalação de postes para acesso à rede elétrica na região dos 
remanescentes de quilombos das comunidades dos Pilões, Maria Rosa e São Pedro, entre outras.

As comunidades dessas áreas foram recentemente reconhecidas como comunidades quilombolas, e tiveram suas terras tituladas em 15/01/2001. Essas comunidades foram reconhecidas como remanescentes de quilombos, após estudo detalhado da Fundação Instituto de Terras do Estado de São Paulo - ITESP (2000), que as caracterizou como "...comunidades negras rurais que agrupam descendentes de escravos vivendo da cultura de subsistência e onde as manifestações culturais têm forte vínculo com o passado".

Parte dessas áreas estavam inseridas no Parque Intervales, e foram excluídas pelo decreto estadual 44.293/99, e parte na Área de Proteção Ambiental da Serra do Mar, excluídas pelo decreto $43.651 / 98$, sendo favorecidas cerca de 110 famílias.

O reconhecimento dessas comunidades abriu caminho para o fortalecimento de outras comunidades remanescentes de quilombos em Iporanga. Algumas delas estão em estudo para reconhecimento, como Nhunguara, Bombas, Rio da Cláudia, João Surrá, Castelhanos e Praia Grande. Dessas comunidades, Nhunguara e Bombas apresentam sobreposição com os Parques Jacupiranga e PETAR, respectivamente. As comunidades Praia Grande e João Surrá apresentam sobreposição com a APA da Serra do Mar

Anteriormente ao reconhecimento dessas comunidades, e exclusão de seus limites das unidades de conservação (APAs e Parques), a legislação ambiental proibía atividades de extrativismo vegetal, estando atualmente algumas áreas com licenças ambientais para plantação de subsistência, obtidas com auxílio do ITESP, condicionadas à conservação das áreas no entorno.

As três comunidades reconhecidas no município de Iporanga apresentam Plano de Desenvolvimento (ITESP, 2000), elaborado em parceria com o ITESP, envolvendo programas de segurança alimentar, diversificação dos sistemas de produção, compativeis com a conservação ambiental, assistência técnica para produção até a comercialização, e articulação junto às comunidades para que tenham atendimento adequado dos serviços públicos (ensino, saúde, comunicação).

O reconhecimento dessas comunidades não as desobriga de procederem ao licenciamento ambiental de suas atividades de exploração de produtos florestais (extrativismo), projetos agricolas e assentamento de familias, conforme relacionadas na resolução Conama $n^{\circ} 237(19 / 12 / 1997)$, o que ressalta a importância da assessoria do ITESP para o desenvolvimento sustentado dessas comunidades. 
Tabela 3.3 - Dinâmica demográfica do Municipio de fporanga. Estimativas geradas pela Fundação SEADE utilizando dados dos sensos disponíveis até 2000.

\begin{tabular}{|c|c|c|c|c|c|c|c|c|c|c|c|c|c|c|c|c|c|c|c|c|c|}
\hline $\begin{array}{l}\text { Demografia } \\
(1980-2000)\end{array}$ & 1980 & 1981 & 1982 & 1983 & 1984 & 1985 & 1986 & 1987 & 1988 & 1989 & 1990 & 1991 & 1992 & 1993 & 1994 & 1995 & 1996 & 1997 & 1998 & 1999 & 2000 \\
\hline $\begin{array}{c}\text { População } \\
\text { (Total) }\end{array}$ & 4719 & 715 & 111 & 05 & 9 & 91 & 682 & 672 & 4661 & 9 & 636 & 621 & 4615 & 4609 & 4603 & 4597 & 591 & 585 & 4579 & 4573 & \\
\hline $\begin{array}{l}\text { População } \\
\text { Urbana }\end{array}$ & 1196 & 240 & 83 & 26 & 69 & 11 & 453 & 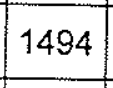 & & & 14 & 1646 & 1700 & 42 & 86 & 831 & 1877 & 924 & 1973 & 2022 & \\
\hline $\begin{array}{c}\text { População } \\
\text { Rural }\end{array}$ & 3523 & 175 & 428 & 3379 & 3330 & 280 & 9 & 78 & 26 & 74 & 3022 & 2975 & 15 & 67 & 17 & 2766 & 2714 & 661 & 606 & 551 & \\
\hline A & 25,35 & 26,30 & 27,23 & 28,18 & 29,13 & 30,08 & 31,03 & 31,98 & 32,93 & 33,88 & 34,81 & 35,62 & 36,84 & 37,80 & 38,80 & 39,83 & 40,88 & 41,96 & 43,09 & 44,22 & 45 \\
\hline
\end{tabular}

A - Taxa de Urbanização (Em \%) (Percentual da populaçăo urbana em relação ao total).

Taxa Geom. Cresc. Anual População - 1991/2000 (Em \% a.a.) $=-0.14 \%$

Taxa Geom. Cresc. Anual População - 1980/1991 (Em \% a.a.) $=-0.19 \%$

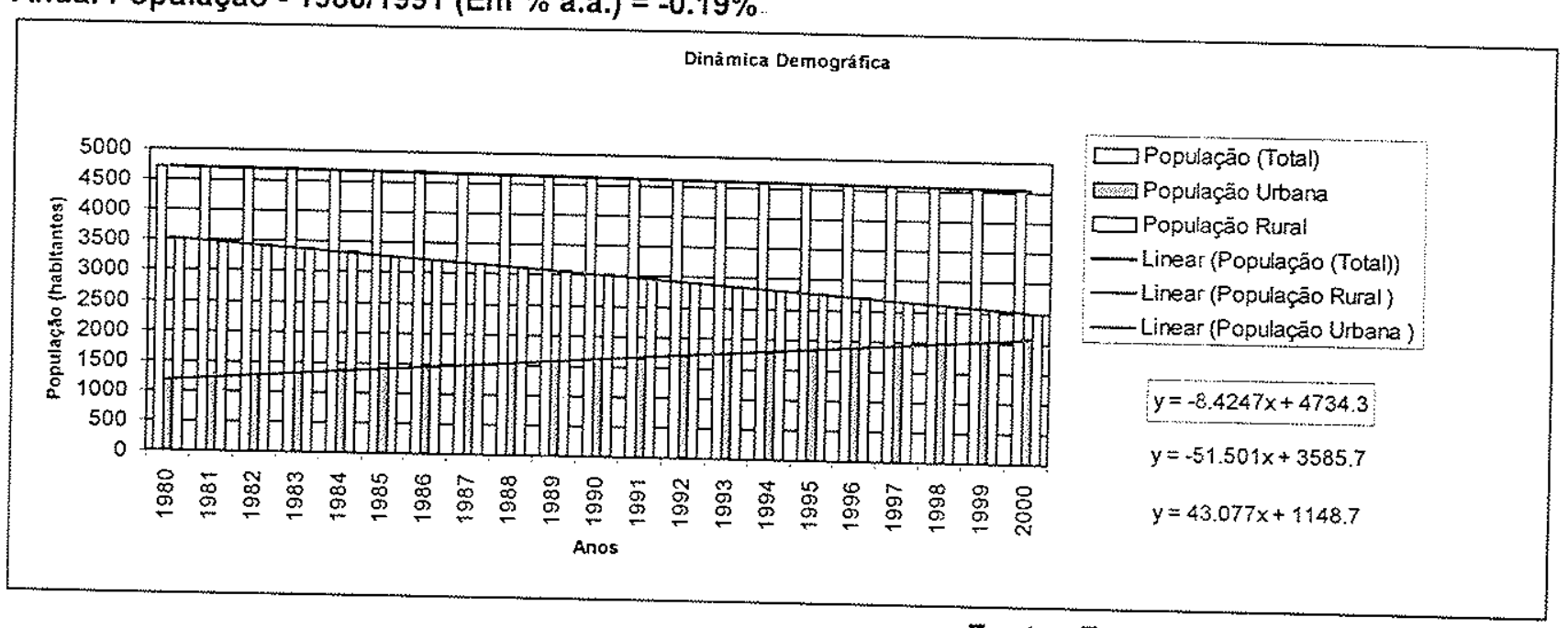

Fonte: Fundação Instituto Brasileiro de Geografia e Estatistica - IBGE Fundação Sistema Estadual de Análise de Dados - SEADE 


\subsubsection{Unidades de conservação no município}

As unidades que ocorrem dentro do municipio de Iporanga estão listadas na Tabela 3.4 e apresentadas na Figura 3.1. As restrições e características de cada unidade de conservação são apresentadas no item referente às categorias de unidades de conservação.

Tabela 3.4 - Unidades de Conservação no município de Iporanga.

\begin{tabular}{|c|c|c|c|}
\hline $\begin{array}{c}\text { Unidades de } \\
\text { Conservação }\end{array}$ & Criação & Área & Municipios Abrangidos \\
\hline $\begin{array}{c}\text { APA da Serra do } \\
\text { Mar }\end{array}$ & $\begin{array}{c}\text { Dec. } N^{\circ} 22.717 \text { de } \\
21 / 09 / 84\end{array}$ & $\begin{array}{c}548.100 \text { hectares } \\
(203.543 \text { hectares } \\
\text { correspondem à zona de vida } \\
\text { silvestre dentro dessa APA) }\end{array}$ & $\begin{array}{c}\text { Apiai, Capão Bonito, Eldorado Paulista, } \\
\text { Guapiara, lbiúna, Iporanga, Juquiá, } \\
\text { Juquitiba, Miracatu, Pedro de Toledo, Pilar } \\
\text { do Sul, Sete Barras e Tapirai }\end{array}$ \\
\hline $\begin{array}{c}\text { Fazenda } \\
\text { Intervales }\end{array}$ & $\begin{array}{c}\text { Próprio Estadual, } \\
\text { administrado pela } \\
\text { Fundação Florestal } \\
\text { desde } 1986\end{array}$ & 38.000 hectares & Eldorado, Iporanga e Sete Barras \\
\hline $\begin{array}{c}\text { Parque Estadual } \\
\text { Turistico do Alto } \\
\text { Ribeira (PETAR) }\end{array}$ & $\begin{array}{c}\text { Dec. } N^{\circ} 28.412 \text { de } \\
20 / 05 / 88\end{array}$ & 36.410 hectares & Iporanga e Apial \\
\hline $\begin{array}{c}\text { Parque Estadual } \\
\text { de Jacupiranga }\end{array}$ & $\begin{array}{c}\text { Dec. Lei } \mathrm{n}^{\circ} 145 \text { de } \\
08 / 08 / 69\end{array}$ & 150.000 hectares & $\begin{array}{c}\text { Jacupiranga, Eldorado Paulista, Barra do } \\
\text { Turvo, Iporanga e Cananéia. }\end{array}$ \\
\hline
\end{tabular}

\subsection{Categorias de unidades de conservação}

São relacionados inicialmente alguns termos e conceitos básicos estipulados pelo Sistema Nacional de Unidades de Conservação - SNUC, conforme a Lei No 9.985 de 18 de julho de 2000 (Brasil. Leis, decretos, etc., 2000). Em seguida são apresentados os dois grupos de unidades de conservação que integram o SNUC.

Unidade de conservação é o espaço territorial e seus recursos ambientais, incluindo as águas jurisdicionais, com características naturais relevantes, legalmente instituído pelo Poder Público, com objetivos de conservação e limites definidos, sob regime especial de administração, ao qual se aplicam garantias adequadas de proteção.

Conservação da Natureza é o manejo do uso humano da natureza, compreendendo a preservação, a manutenção, a utilização sustentável, a restauração 


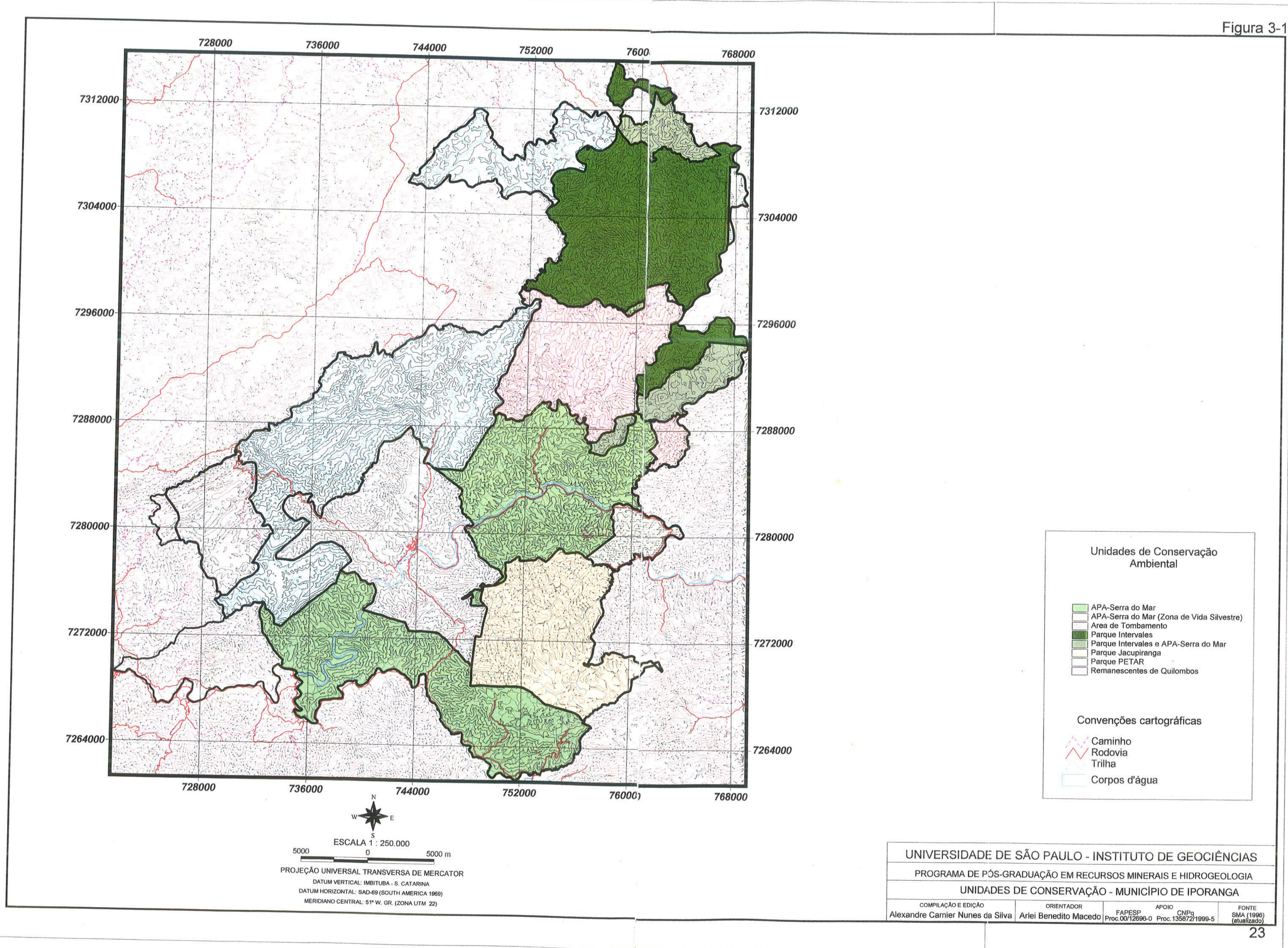


e a recuperação do ambiente natural, para que possa produzir o maior benefício, em bases sustentáveis, às atuais gerações, mantendo o seu potencial de satisfazer às necessidades e aspirações das gerações futuras, e garantindo a sobrevivência dos seres vivos em geral.

Diversidade Biológica diz respeito à variabilidade de organismos vivos de todas as origens, compreendendo, dentre outros, os ecossistemas terrestres, marinhos e outros ecossistemas aquáticos e os complexos ecológicos de que fazem parte. Compreende ainda a diversidade dentro de espécies, entre espécies $e$ de ecossistemas.

Preservação é o conjunto de métodos, procedimentos e políticas que visem a proteção a longo prazo das espécies, hábitats e ecossistemas, além da manutenção dos processos ecológicos, prevenindo a simplificação dos sistemas naturais.

Proteção Integral é a manutenção dos ecossistemas livres de alterações causadas por interferência humana, admitido apenas o uso indireto dos seus atributos naturais.

Manejo é todo e qualquer procedimento que vise assegurar a conservação da diversidade biológica e dos ecossistemas.

Uso indireto é aquele que não envolve consumo, coleta, dano ou destruição dos recursos naturais. Já o Uso direto é aquele que envolve coleta e uso, comercial ou não, dos recursos naturais.

Uso Sustentável é a exploração do ambiente de maneira a garantir a perenidade dos recursos ambientais renováveis e dos processos ecológicos, mantendo a biodiversidade e os demais atributos ecológicos, de forma socialmente justa e economicamente viável.

Extrativismo é o sistema de exploração baseado na coleta e extração, de modo sustentável, de recursos naturais renováveis.

Recuperação é a restituição de um ecossistema ou de uma população silvestre degradada a uma condição não degradada, que pode ser diferente de sua condição original.

Zoneamento é a definição de setores ou zonas em uma unidade de conservação com objetivos de manejo e normas especificos, com o propósito de proporcionar os meios e as condições para que todos os objetivos da unidade possam ser alcançados de forma harmônica e eficaz.

Plano de manejo é o documento técnico mediante o qual, com fundamento nos objetivos gerais de uma unidade de conservação, se estabelece o seu zoneamento e 
as normas que devem presidir o uso da área e o manejo dos recursos naturais, inclusive a implantação das estruturas físicas necessárias à gestão da unidade.

Zona de amortecimento é o entorno de uma unidade de conservação, onde as atividades humanas estão sujeitas a normas e restrições especificas, com o propósito de minimizar os impactos negativos sobre a unidade.

As unidades de conservação integrantes do SNUC dividem-se em dois grupos com características específicas: Unidades de Proteção Integral e Unidades de Uso Sustentável.

\subsubsection{Unidades de Proteção Integral}

O objetivo básico das Unidades de Proteção Integral é preservar a natureza, sendo admitido apenas o uso indireto dos seus recursos naturais, com exceção dos casos previstos nesta Lei. É composta pelas seguintes categorias de unidade de conservação:

I - Estação Ecológica;

II - Reserva Biológica;

III - Parque Nacional;

IV - Monumento Natural;

V-Refúgio de Vida Silvestre.

\subsubsection{Estações ecológicas}

A Estação Ecológica tem como objetivo a preservação da natureza e a realização de pesquisas científicas. É de posse e domínio público, sendo que as áreas particulares incluídas em seus limites serão desapropriadas, de acordo com o que dispõe a Lei. É proibida a visitação pública, exceto quando com objetivo educacional, de acordo com o que dispuser o Plano de Manejo da unidade ou regulamento especifico. A pesquisa científica depende de autorização prévia do órgão responsável pela administração da unidade e está sujeita às condições e restrições por este estabelecidas, bem como àquelas previstas em regulamento.

Na Estação Ecológica só podem ser permitidas alterações dos ecossistemas no caso de:

1 - medidas que visem a restauração de ecossistemas modificados;

II - manejo de espécies com o fim de preservar a diversidade biológica;

III - coleta de componentes dos ecossistemas com finalidades científicas; 
IV - pesquisas científicas, cujo impacto sobre o ambiente seja maior do que aquele causado pela simples observação ou pela coleta controlada de componentes dos ecossistemas, em uma área correspondente a no máximo três por cento da extensão total da unidade e até o limite de um mil e quinhentos hectares.

\subsubsection{Reservas Biológicas}

A Reserva Biológica tem como objetivo a preservação integral da biota e demais atributos naturais existentes em seus limites, sem interferência humana direta ou modificações ambientais, excetuando-se as medidas de recuperação de seus ecossistemas alterados e as ações de manejo necessárias para recuperar e preservar o equilíbrio natural, a diversidade biológica e os processos ecológicos naturais. $\dot{E}$ de posse e domínio público, sendo que as áreas particulares incluídas em seus limites serão desapropriadas, de acordo com o que dispõe a Lei. É proibida a visitação pública, exceto aquela com o objetivo educacional, de acordo com regulamento específico. A pesquisa científica depende de autorização prévia do órgão responsável pela administração da unidade e está sujeita às condições e restrições por este estabelecidas, bem como àquelas previstas em regulamento.

\subsubsection{Parque Nacional}

O Parque Nacional tem como objetivo básico a preservação de ecossistemas naturais de grande relevância ecológica e beleza cênica, possibilitando a realizaçäo de pesquisas científicas e o desenvolvimento de atividades de educação e interpretação ambiental, de recreação em contato com a natureza e de turismo ecológico. É de posse e domínio público, sendo que as áreas particulares incluidas em seus limites serão desapropriadas, de acordo com o que dispõe a Lei. A visitação pública está sujeita às normas e restrições estabelecidas no Plano de Manejo da unidade, às normas estabelecidas pelo órgão responsável por sua administração, e àquelas previstas em regulamento. A pesquisa cientifica depende de autorização prévia do órgão responsável pela administração da unidade e está sujeita às condições e restrições por este estabelecidas, bem como àquelas previstas em regulamento. As unidades dessa categoria, quando criadas pelo Estado ou Municipio, serão denominadas, respectivamente, Parque Estadual e Parque Natural Municipal. 


\subsubsection{Unidades de Uso Sustentável}

O objetivo básico das Unidades de Uso Sustentável é compatibilizar a conservação da natureza com o uso sustentável de parcela dos seus recursos naturais.

\subsubsection{1 Áreas de Proteção Ambiental (APAs)}

A Área de Proteção Ambiental é uma área em geral extensa, com um certo grau de ocupação humana, dotada de atributos abióticos, bióticos, estéticos ou culturais especialmente importantes para a qualidade de vida e o bem-estar das populações humanas, e tem como objetivos básicos proteger a diversidade biológica, disciplinar o processo de ocupação e assegurar a sustentabilidade do uso dos recursos naturais. É constituída por terras públicas ou privadas. Respeitados os limites constitucionais, podem ser estabelecidas normas e restrições para a utilização de uma propriedade privada localizada em uma Área de Proteção Ambiental.

\subsubsection{2 Áreas de Relevante Interesse Ecológico (ARIEs)}

A Área de Relevante Interesse Ecológico é uma área em geral de pequena extensão, com pouca ou nenhuma ocupação humana, com características naturais extraordinárias ou que abriga exemplares raros da biota regional, e tem como objetivo manter os ecossistemas naturais de importância regional ou local e regular o uso admissivel dessas áreas, de modo a compatibilizá-lo com os objetivos de conservação da natureza. É constituída por terras públicas ou privadas.

\subsubsection{Reservas da Biosfera (REBIOs)}

A Reserva da Biosfera é um modelo, adotado internacionalmente, de gestão integrada, participativa e sustentável dos recursos naturais, com os objetivos básicos de preservação da diversidade biológica, o desenvolvimento de atividades de pesquisa, o monitoramento ambiental, a educação ambiental, o desenvolvimento sustentável e a melhoria da qualidade de vida das populações. É constituída por uma ou várias áreasnúcleo, destinadas à proteção integral da natureza; uma ou várias zonas de amortecimento, onde só são admitidas atividades que não resultem em dano para as áreas-núcleo; e uma ou várias zonas de transição, sem limites rígidos, onde o processo de ocupação e o manejo dos recursos naturais são planejados e conduzidos de modo participativo e em bases sustentáveis. É constituída por áreas de domínio público ou privado. 


\subsubsection{Compatibilidade de zonas de manejo nas unidades de conservação}

A Tabela 3.5 apresenta a comparação entre as zonas de manejo compativeis em cada categoria de unidade de conservação definida no Sistema Nacional de Unidades de Conservação.

Tabela 3.5 - Compatibilidade de zonas de manejo e categorias de manejo de unidades de conservaçāo.

\begin{tabular}{|c|c|c|c|c|c|c|c|c|c|c|c|c|}
\hline ZONAS & Parque & $\begin{array}{l}\text { Reserva } \\
\text { Biológica }\end{array}$ & $\begin{array}{l}\text { Estaçăo } \\
\text { Ecológica }\end{array}$ & $\begin{array}{c}\text { Monumento } \\
\text { Natural }\end{array}$ & $\begin{array}{l}\text { Refúgio } \\
\text { de Vida } \\
\text { Silvestre }\end{array}$ & APA & ARIE & Floresta & $\begin{array}{c}\text { Reserva } \\
\text { Extrativista }\end{array}$ & $\begin{array}{c}\text { Reserva de } \\
\text { Fauna }\end{array}$ & \begin{tabular}{|c|} 
Reserva de \\
Desenvolvimento \\
Sustentável
\end{tabular} & RPPN \\
\hline $\begin{array}{l}\text { 1. Intangivel } \\
\text { 2. Primitiva }\end{array}$ & $x$ & $x$ & $\bar{x}$ & $x$ & $x$ & $\bar{x}$ & $\bar{x}$ & 0 & 0 & 0 & 0 & $x$ \\
\hline & $\frac{x}{x}$ & $x$ & $\mathrm{x}$ & $x$ & $\mathrm{x}$ & $x$ & $\bar{x}$ & $x$ & $\bar{x}$ & $x$ & $x$ & $x$ \\
\hline $\begin{array}{l}\text { 3. De Uso Extensivo } \\
\text { 4. De Uso Intensivo }\end{array}$ & $\frac{x}{x}$ & 0 & $x$ & $x$ & $x$ & $x$ & $\bar{x}$ & $\bar{x}$ & $x$ & $\bar{x}$ & $x$ & $\bar{x}$ \\
\hline 5. Histórico-Cultural & $\frac{x}{x}$ & $\frac{0}{x}$ & 0 & $x$ & 0 & $x$ & 0 & $x$ & $x$ & 0 & $x$ & 0 \\
\hline 6. De Recuperaça & $\frac{x}{x}$ & $\frac{x}{x}$ & $\mathrm{x}$ & $x$ & $x$ & $x$ & $x$ & $x$ & $x$ & $x$ & $\mathrm{x}$ & $\underline{x}$ \\
\hline 7. De Interferência Experimental & 0 & $\frac{x}{0}$ & $\frac{x}{y}$ & $\frac{x}{x}$ & $x$ & $\mathrm{x}$ & $x$ & $\bar{x}$ & $\bar{x}$ & $\bar{x}$ & $\underline{x}$ & $x$ \\
\hline 8. De Uso Especial & $x$ & $\frac{0}{x}$ & $\frac{x}{x}$ & 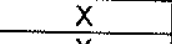 & $x$ & $x$ & 0 & $\mathrm{x}$ & $x$ & $x$ & $x$ & $x$ \\
\hline 9. Particular de Protecão & 0 & $\frac{1}{0}$ & $x$ & $x$ & $x$ & $x$ & $x$ & $x$ & $\bar{x}$ & $x$ & $\mathrm{X}$ & $\mathrm{x}$ \\
\hline 10. De Uso Sustentável & 0 & 0 & $\frac{0}{0}$ & $x$ & $\bar{x}$ & $x$ & 0 & 0 & 0 & 0 & 0 & $x$ \\
\hline 11. De Ocupaçăo Humana & 0 & 0 & $\frac{0}{0}$ & $x$ & 0 & $x$ & 0 & $x$ & $x$ & $\mathrm{X}$ & $\bar{x}$ & $\bar{x}$ \\
\hline 12. De Populacōes Tradicionais & 0 & 0 & $\frac{0}{0}$ & $x$ & $x$ & $x$ & 0 & 0 & $x$ & $\mathrm{x}$ & 0 & 0 \\
\hline 13. De Exploracão de Recursos Minerais & 0 & 0 & $\frac{0}{0}$ & $x$ & $\underline{x}$ & $x$ & 0 & $\bar{x}$ & $x$ & $x$ & $x$ & 0 \\
\hline $\mathrm{X}$ : Compativel $0:$ & & & 0 & 0 & 0 & $\mathrm{X}$ & 0 & 0 & 0 & 0 & 0 & 0 \\
\hline
\end{tabular}




\subsection{Sistemas de informação geográfica (SIGs)}

Um Sistema de Informação Geográfica, ou simplesmente SIG, segundo Bonham-Carter (1996), pode ser entendido como um sistema de computador para o gerenciamento de dados espaciais, formado por componentes diversos, interrelacionados e ligados a diferentes funções, exercendo tarefas de entrada, manipulação, transformação, visualização, combinação, buscas, análises, modelagem e saída. Também são denominados sistemas de informações georreferenciadas ou sistemas geográficos de informação.

Burrough (1986) define o SIG como um conjunto de ferramentas elaboradas para a coleta, armazenamento, recuperação, transformação e visualização espacial de dados com propósitos específicos.

Cowen (1988) define o SIG como uma ferramenta de suporte à decisão que combina: a capacidade de manipulação dos atributos dos dados geográficos, com a capacidade de manipulação de dados espaciais, permitindo identificar informações que respondam a múltiplos critérios, mesmo que os atributos e dados espaciais estejam associados a diferentes tipos de arquivos.

Bonham-Carter (1996) ressalta os significados associados ao termo SIG. A palavra "geográfica" implica que a localização dos dados é conhecida, ou pode ser calculada, em termos de coordenadas geográficas (latitude, longitude). A maioria dos SIGs trabalha com dados em duas dimensões espaciais, apesar de alguns sistemas realizarem análise em $3 \mathrm{D}^{3}$ e representações de feições reais complexas, como dobras e outras estruturas geológicas. A palavra "informação" implica que os dados em um SIG são organizados para produzir conhecimento útil, freqüentemente na forma de mapas e imagens coloridas, mas também como gráficos estatísticos, tabelas e respostas diversas na tela para perguntas interativas. A palavra "sistema" implica que o SIG é feito a partir de componentes diversos, interrelacionados e ligados com diferentes funções. Assim o SIG tem capacidade funcional para executar as seguintes funções:

- Captura e entrada de dados;

- Manipulação e transformação;

- Visualização e combinação;

${ }^{3} A$ análise de dados em 3D reais permite a quantificação de dados com variação contínua ao longo da dimensão $z$. 
- Consulta e análise;

- Modelagem e produção cartográfica;

Esse conjunto de funções auxilia o processo de tomada de decisão por possibilitar a transformação de dados em informações úteis. O SIG tem como especialidade auxiliar os usuários na transformação de dados geográficos em informação.

Outro componente fundamental no sistema é o próprio usuário que interage com uma interface, que proporciona acesso a funções particulares dos diversos programas e rotinas disponiveis no sistema. O usuário pode controlar as operaçōes no SIG utilizando essa interface gráfica, chamada de GUI (Graphical User Interface), ou através de uma linguagem por comandos (Command Language), consistindo de declarações do programa que definem a seqüência e tipos de operações a serem realizadas. Algumas dessas ferramentas computacionais permitem a manipulação de mapas, imagens digitais e banco de dados tabulares geocodificados, entre outras funções.

A característica principal que os SIGs apresentam é a capacidade de unir dados espaciais de fontes diversas em uma base de dados unificada, freqüentemente empregando uma variedade de estruturas de dados digitais. Diversos fenômenos de variação espacial podem ser representados como planos de informação, tais como: unidades geológicas, declividade do terreno, direção da vertente, etc; os quais estão em um mesmo registro espacial, significando que coincidem em todas as posições.

\subsubsection{Desenvolvimento do SIG}

O desenvolvimento dos Sistemas de Informação Geográfica está diretamente ligado à evolução da área de computação, cuja história tem como marco as décadas de 40 e 50, quando foram desenvolvidos equipamentos e métodos que viabilizaram a implementação de rotinas para automação de determinados processos de análise espacial. Os primeiros sistemas desenvolvidos, na década de 60 , restringiam-se a agências governamentais (americanas e canadenses), em virtude dos custos elevados e dos problemas de implementação, ocorrendo nas décadas seguintes avanços consideráveis em equipamentos e software, o que permitiu o desenvolvimento de sistemas mais potentes e novas aplicações, e ao mesmo tempo, com a redução dos custos dos equipamentos, os SIGs tornaram-se uma tecnologia de rápida difusão e aceitação (Teixeira et al., 1992).

Burrough (1986) destaca que historicamente, durante a utilização de computadores para mapeamento e análise espacial, ocorreu um desenvolvimento 
paralelo nos procedimentos de captura (CAD), análise de dados e apresentação gráfica, nas diversas áreas do conhecimento que utilizam representações espaciais como: mapeamento topográfico, cartografia temática, engenharia civil, geografia, ciência dos solos, planejamento rural e urbano e sensoriamento remoto.

Bonham-Carter (1996), Teixeira et al. (1992), entre outros descrevem as diferenças entre os sistemas de desenho auxiliado por computador, CAD (Computer Aided Design) e os SIGs, relacionando que os sistemas de desenho tipo CAD constituem uma ferramenta de desenho digital e não necessariamente de processamento de informação digital. Um CAD geralmente possui funções que permitem a representação precisa de linhas e formas, podendo ser utilizado, por exemplo, na digitalização de mapas e cartas. Entretanto apresenta limitações no que diz respeito à atribuição de outras informações aos elementos gráficos digitalizados.

Apesar disso o CAD pode ser empregado em conjunto com SIG, quando se deseja utilizar o desenho produzido em um CAD como a base onde serão lançados os atributos dos elementos temáticos estudados no SIG.

\subsubsection{Geoprocessamento}

Em um contexto mais amplo, os SIGs incluem-se no ambiente tecnológico que se convencionou chamar de geoprocessamento, cuja área de atuação envolve a coleta e tratamento da informação espacial, assim como o desenvolvimento de novos sistemas e aplicações. A tecnologia ligada ao geoprocessamento envolve equipamentos (hardware) e programas (software) com diversos niveis de sofisticação destinados à implementação de sistemas com fins didáticos, de pesquisa acadêmica ou aplicações profissionais e científicas nos mais diversos ramos das geociências (Teixeira et al., 1992).

\subsubsection{Fontes de dados}

As fontes de dados em SIG podem ser agrupadas em primárias e secundárias. Os dados originados de levantamentos de campo, ou produtos de sensoriamento remoto, por exemplo, são classificados como dados primários, e os demais dados derivados das fontes primárias, são classificados como dados secundários (Teixeira et al., 1992).

A compatibilização entre os planos de informação é um dos fatores mais importantes na elaboração de uma base de dados, permitindo que os diversos temas tratados sejam comparáveis. A definição da área de trabalho deve então utilizar bases 
cartográficas com sistema de projeção, coordenadas e escalas adequadas aos objetivos do trabalho.

Os elementos espaciais podem ser: pontos, linhas e áreas definidos sobre um sistema conhecido de coordenadas, relacionados com um valor identificador, que permite associar os elementos gráficos à representação na forma alfa-numérica simbólica.

A dimensão tempo refere-se à variação temática em épocas distintas. Neste caso, novos niveis de informação (temas) vão sendo agregados à base de dados ou, caso necessário, novas bases vão sendo criadas, seja pela modificação do uso do solo, ou modificações nos mapeamentos básicos, por exemplo.

\subsubsection{Estruturas de representação de dados espaciais}

A representação do espaço pode utilizar estruturas diversificadas, que podem ser classificadas em geométricas e não-geométricas. As estruturas não-geométricas utilizam dados que incluem atributos como nome, população, atividade econômica etc, e relações não-geométricas entre elementos. As estruturas geométricas descrevem diversos atributos de um elemento, como sua posição e suas relações de vizinhança ou de conexão com outros elementos (topologia).

As estruturas geométricas podem ser subdivididas em matriciais (raster) e vetoriais. A diferença básica entre as duas está no modelo de espaço adotado em cada uma. A estrutura vetorial considera o espaço geográfico contínuo, seguindo postulados da Geometria Euclidiana, enquanto a estrutura matricial divide o espaço em elementos discretos (Teixeira et al., 1992).

\subsubsection{Estruturas matriciais}

A estrutura matricial (raster) é uma representação espacial que pode ser obtida definindo-se uma malha com linhas verticais e horizontais espaçadas regularmente, formando células, sobre os dados a serem representados. Tais células, ou pixels, geralmente possuem dimensões verticais e horizontais iguais, que definem a resolução espacial, ou seja, a área do terreno representada por cada célula.

A relação espacial entre os pixels é implícita, em função das coordenadas da malha, ou seja, não são armazenadas coordenadas para cada célula; por apresentar uma forma regular, as linhas e as colunas permitem localizar um elemento, e efetuar análises simples como vizinhança, distância, entre outras (Figura 3.2).

Para exemplificar uma estrutura matricial pode-se considerar uma base de dados referente a um município onde estão armazenadas informações como uso do 
solo, pedologia e vegetação (Figura 3.3). Cada tema pode apresentar várias classes que são codificadas por números (identificadores), onde cada pixel mantém sempre a mesma localização espacial armazenando atributos referentes a cada tema.

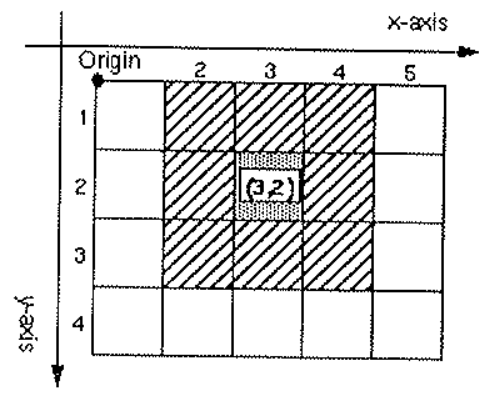

(A)

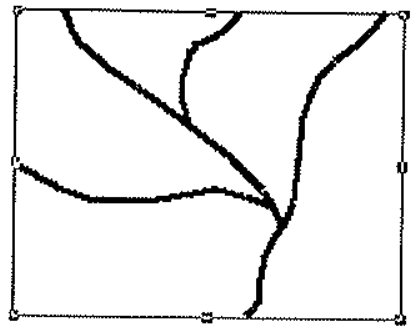

(B)

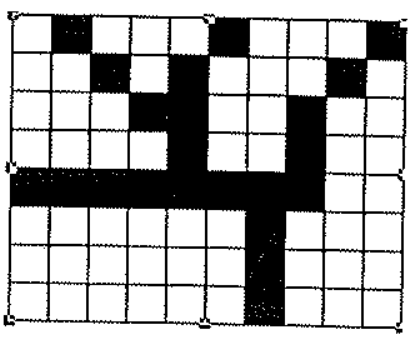

(C)

Figura 3.2 - (A) Modelo de representação matricial; (B) Representação vetorial da rede de drenagem; (C) Representação matricial da rede de drenagem;

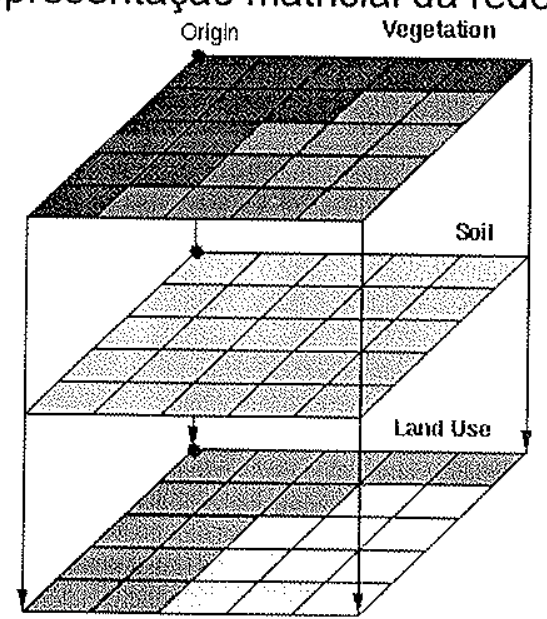

Figura 3.3 - Estrutura matricial representando uma base de dados com temas de Vegetação, Pedologia e Uso do Solo.

Teixeira et al. (1992) relacionam as vantagens e desvantagens do tipos de representação matricial, algumas vantagens são:

- Relativa simplicidade da estrutura, não exigindo programas muito complexos para a manipulação dos dados;

- Não exige alta capacidade de processamento dos equipamentos utilizados;

- Esse formato pode empregar estratégias de compactação, o que permite diminuir o volume de dados a serem armazenados (blocos e Quadtrees);

As desvantagens são:

- A precisão dos mapas digitais obtidos depende diretamente da resolução utilizada, implicando em dificuldades na representação de pequenas áreas ou feições lineares como rios e estradas;

- Quanto maior a resolução da malha maior será o tempo gasto no processo de digitalização, exigindo também equipamento mais eficiente;

- Limitação da qualidade visual dos mapas finais; 


\subsubsection{Estruturas Vetoriais}

A representação vetorial de um elemento é uma tentativa de reproduzi-lo o mais exatamente possivel. Assume-se o espaço como contínuo, o que permite que todas as posiçōes, distâncias e áreas sejam definidas com um grau de precisão muito maior. Os métodos vetoriais assumem que as coordenadas dos pontos são matematicamente mais exatas. Além disso, usam relações implícitas, permitindo que dados complexos sejam armazenados utilizando menor espaço no computador.

São três as formas básicas de representação vetorial que podem ser empregadas:

- Elementos pontuais: Os elementos pontuais abrangem todas as entidades geográficas que podem ser perfeitamente posicionadas por um único par de coordenadas $x, y$, estando ligado a um identificador.

- Linhas: Os elementos lineares podem ser considerados como um conjunto de pelo menos dois pontos, estando também ligado a um identificador. As linhas que armazenam informação a respeito das ligações entre elas, constituem redes, e permitem análises de rota, caminho mínimo, etc.

- Polígonos: A estrutura poligonal permite o armazenamento de propriedades topológicas, como a forma, vizinhança, hierarquia etc., de maneira que os atributos associados aos identificadores de cada polígono podem ser manipulados. Nessa representação cada polígono, com identificador único, armazena informações sobre área, perímetro e atributos associados.

\subsubsection{Componentes de um SIG}

Os SIGs podem ser vistos como a combinação de hardware, um sistema gerenciador de banco de dados, um conjunto de programas dedicados à execução de operações sobre os dados e recursos humanos.

\subsubsection{Sistema Gerenciador de Banco de dados}

O sistema gerenciador de banco de dados é composto por programas que permitem executar rotinas de manutenção e controle da base de dados física, que é composta de arquivos que armazenam os dados alfanuméricos.

A organização de arquivos no banco de dados é feita, na maioria das vezes, baseada em três estruturas: hierárquica, relacional e em rede (Teixeira et al., 1992). Diversos tipos de bancos de dados podem ser usados em sistemas de informação 
geográfica, alguns SIGs utilizam bancos de dados desenvolvidos especificamente para o sistema, outros trabalham com banco de dados externos tipo DBASE, ORACLE, INFORMIX, SYBASE, ACCESS, ocorrendo também sistemas abertos às duas possibilidades.

\subsection{Base de dados}

Os arquivos de dados podem ser armazenados em diferentes estruturas, as mais utilizadas são (Teixeira et al., 1992):

- Listas: são as formas mais simples de armazenamento, consistindo em uma seqüência desorganizada de itens, onde cada novo elemento é acrescentado sempre ao final da lista;

- Seqüências: apresentam itens seguindo uma determinada ordem, facilitando as buscas, mas dificultando a inserção de novos dados;

- Arquivos indexados: a ordem dos elementos é dada por uma tabela em outro arquivo que aponta a seqüência em que a busca deve ser feita.

Um dos aspectos importantes é a checagem de dados antes de sua entrada efetiva no sistema, evitando-se a presença de erros que podem comprometer qualquer processo posterior. Geralmente os SIGs possuem processos de checagem automática da topologia, correção gráfica, checagem de linhas e colunas, atributos, coordenadas, etc.

\subsection{Operações sobre os dados}

As operações realizadas sobre os dados podem ser divididas, segundo Teixeira et al. (1992), em pré-processamento e processamento digital.

As funções de pré-processamento permitem modificar os dados como um todo visando os seguintes objetivos:

- Mudança de escala;

- Mudança de projeção cartográfica;

- Mudança de estrutura (matricial - vetorial);

- União de bases de dados;

- Conversão entre tipos de arquivos; entre outros.

As funções de processamento visam extrair informações da base de dados ou criar novas informações derivadas, de acordo com as necessidades do usuário.

Entre estas funções destacam-se:

- Localização de uma entidade e listagem de seus atributos; 
- Atualização de dados;

- Cálculo de área, perímetro e distâncias;

- Posicionamento;

- Operações aritméticas entre planos (soma, subtração, divisão, multiplicação, etc.);

- Cálculos estatísticos (correlação, regressão, etc.);

- Classificação dos dados;

- Cruzamento entre planos;

- Filtragens espaciais; etc. 


\section{CAPÍTULO 4 - REVISÃo BIBLIOGRÁFICA}

\subsection{Planejamento territorial}

Vedovello (2000) aborda os instrumentos de gestão ambiental de regiões, utilizando a denominação definida por Bitar e Ortega (1998), diferenciando os seguintes instrumentos de gestão ambiental de regiões,

- Planos de Manejo;

- Zoneamentos ambientais;

- Zoneamentos Ecológico-econômicos;

- Planos Diretores Municipais;

Esses instrumentos relacionam-se diretamente às políticas ambientais determinadas para cada região, e necessitam de informações variadas sobre o meio físico para sua elaboração.

No caso do município de Iporanga, o principal instrumento aplicado é o Plano de Manejo, devido à grande área ocupada por unidades de conservação no município.

\subsubsection{Planos de manejo}

O principal objetivo dos planos de manejo é apontar medidas que garantam a preservação de um patrimônio ambiental (natural, urbanístico ou cultural) de uma área (Vedovello, 2000).

O mesmo autor relaciona as seguintes etapas para a elaboração do plano de manejo:

- Diagnóstico: atividades de levantamento e análise de dados e informações sobre os meios físico e biótico, e condições de uso e ocupação do solo;

- Definição de objetivos e diretrizes gerais: refere-se à identificação de restrições e recomendações gerais, baseadas nas potencialidades e fragilidades da área, que permite um planejamento de ações para manutenção ou melhoria do quadro atual, definindo um cenário desejado;

- Regulamentação das formas de uso e ocupação do solo: elaboração de diretrizes e normas específicas e detalhadas que ordenam os diferentes tipos de uso e ocupação previstos e/ou existentes na área; 


\subsection{Cartas de geologia de engenharia}

Zuquete e Nakazawa (1998) apresentam os tipos de cartas e mapas de Geologia de Engenharia mais utilizados nas diferentes etapas de implantação de obras de Engenharia Civil e nos processos de planejamento territorial, urbano e ambiental, incluindo estudos de conservação do meio ambiente.

A interface da Geologia de Engenharia com a Mecânica de Solos e das Rochas, no campo da Geotecnia permite definir os documentos produzidos como mapas geotécnicos ou cartas geotécnicas (Vedovello, 2000, Zuquete e Nakazawa, 1998).

Vedovello (2000) ressalta ainda que o campo de atuação da Geologia de Engenharia não inclui apenas a interface com a Engenharia Civil, mas também com os demais relacionamentos entre as atividades humanas e o meio físico geológico, subsidiando tecnicamente as diversas atividades humanas, permitindo um planejamento de intervenções com base na análise do meio físico.

Zuquete e Nakazawa (1998) definem diferentes grupos de objetivos em que as cartas e mapas de Geologia de Engenharia podem ser aplicados:

- obras civis;

- planejamento urbano, territorial e ambiental; desenvolvimento e conservação do meio ambiente;

O segundo grupo de objetivos, o planejamento territorial e ambiental, constitui parte do escopo deste trabalho que podem ser classificados quanto a diferentes aspectos, dentre os quais destacam-se dois, segundo Zuquete (1993) apud Zuquete e Nakazawa (1998):

- quanto ao conteúdo:

- mapas fundamentais: documentos gráficos que registram as informações sobre os diferentes componentes do meio físico;

- cartas derivadas: elaboradas a partir de um mapa fundamental, atendendo a uma determinada finalidade;

- cartas interpretativas: desenvolvidas a partir de atributos que estão registrados nos diferentes mapas fundamentais.

- quanto à finalidade:

- cartas para usos múltiplos: efetuadas no sentido de atender a um grupo de objetivos e, portanto, de diferentes usuários;

- cartas para usos específicos: documentos cartográficos desenvolvidos para atender situações especificas ou especiais.

Cerri (1990) divide as cartas geotécnicas no Brasil em quatro grandes grupos: 
- Cartas geotécnicas clássicas, desenvolvidas a partir de unidades de análise, ensaios de campo e mapas temáticos, resultando em compartimentos geológicogeotécnicos, analisados em conjunto com o uso e ocupação do solo;

- Cartas de suscetibilidade, desenvolvidas a partir de um processo geológico que é analisado através de mapas temáticos, mais o uso e ocupação do solo enquanto potencializador do processo;

- Cartas de risco, desenvolvidas através da carta de suscetibilidade, mais o uso e ocupação do solo enquanto conseqüência social e econômica; e

- Cartas de conflito de uso, desenvolvidas através do diagnóstico do meio físico com uso e ocupação atual do solo, analisando-se os problemas de ordem geológico-geotécnica.

Essa definição é adotada por Nakazawa et al. (1991) e por Bitar et al. (1992), com ligeiras diferenças em relação à divisão dos grupos e faz parte da evolução da sistemática adotada pelo IPT (Ridente Jr., 2000), que define: cartas geotécnicas dirigidas, cartas geotécnicas convencionais, cartas de suscetibilidade e cartas de risco geológico (Tabela 4.1).

Segundo Bitar et al. (1992), nas cartas de risco geológico prepondera a avaliação quanto ao dano à ocupação e são as apresentadas em escalas maiores, sendo realizadas principalmente para os processos de escorregamentos e processos correlatos, nos quais os prejuízos socio-econômicos são diretamente identificáveis.

No entanto, para alguns tipos de processos especificos, como a erosão, colapsividade de solos etc., a quantificação do prejuizo socio-econômico e, consequentemente do risco, é mais difícil, pois, tratam-se de processos lentos e de pouca relação com a perda de vidas humanas (Cerri, 1993).

A concepção adotada neste trabalho é aquela definida para por Cerri (op. cit.), como cartas de suscetibilidade, considerando a distinção entre cartas e mapas de Zuquete e Nakazawa (1998), que define o termo mapa como documento que registra as informações (atributos), obtidos de um determinado aspecto do meio físico em questão, sem que sejam realizadas interpretações dessas informações, e o termo carta refere-se a um documento cartográfico que apresenta as interpretaçōes de informações contidas em mapas para uma finalidade específica. 
Tabela 4.1 - Tipos de cartas geotécnicas produzidas no Brasil.

\begin{tabular}{|c|c|c|c|}
\hline $\begin{array}{r}\text { Cartas } 9 \\
\text { dir }\end{array}$ & $\mathrm{Ca}$ & $\begin{array}{r}\text { Ca } \\
\text { susce }\end{array}$ & $\begin{array}{l}\text { sco } \\
0\end{array}$ \\
\hline $\begin{array}{c}\text { Expõem as limitações e } \\
\text { potencialidades dos } \\
\text { terrenos, ante a } \\
\text { identificaçăo de problemas } \\
\text { de natureza geológico } \\
\text { geotécnica, estabelecendo } \\
\text { alternativas de solução } \\
\text { destes problemas e } \\
\text { apontando diretrizes para o } \\
\text { adensamento e expansão } \\
\text { da ocupação ante a uma } \\
\text { ou mais formas de uso do } \\
\text { solo. }\end{array}$ & \begin{tabular}{|c|} 
Apresentam a \\
distribuição geográfica \\
das características dos \\
terrenos, a partir de \\
atributos do meio físico e \\
de determinados \\
parâmetros geologico- \\
geotécnicos, muitas \\
vezes sem considerar as \\
interações existentes \\
entre o meio físico e as \\
diferentes formas de uso \\
do solo.
\end{tabular} & $\begin{array}{c}\text { Indicam a potencialidade } \\
\text { de ocorrência de } \\
\text { processos geológicos } \\
\text { naturais e induzidos em } \\
\text { áreas de interesse ao uso } \\
\text { do solo, expressando a } \\
\text { suscetibilidade segundo } \\
\text { classes de probabilidade } \\
\text { de ocorrência. }\end{array}$ & $\begin{array}{c}\text { Preponderam a avaliação } \\
\text { de dano potencial à } \\
\text { ocupação expressos } \\
\text { segundo diferentes graus } \\
\text { de risco, resultantes da } \\
\text { conjugação da } \\
\text { probabilidade de } \\
\text { ocorrência de } \\
\text { manifestações geológicas } \\
\text { naturais ou induzidas e } \\
\text { das conseqüências } \\
\text { sociais e econômicas } \\
\text { decorrentes. }\end{array}$ \\
\hline
\end{tabular}

Fonte: Bitar et al. (1992) apud Ridente (2000).

\subsection{Dinâmica superficial: processos geológicos}

Os processos de dinâmica superficial são aqueles que modificam a superficie da Terra e que agem na interface entre a hidrosfera, a atmosfera e a litosfera, processos que são resultantes da atuação da energia solar e gravitacional (Infante Jr. e Fornasari Filho, 1998). A dinâmica superficial modela a superficie da Terra e produz diferentes paisagens conforme a estruturação geológica, climática e o tempo de atuação dos processos.

Mayer (1990) apud Infante Jr. e Fornasari Fitho (1998) descreve os conceitos de tempo, velocidade e espaço:

O tempo pode ser compreendido como uma seqüência cumulativa de eventos, medidas em intervalos de incremento iguais, por instrumentos ou manifestação de fenômenos naturais, seguindo somente em uma direção, o que determina a irreversibilidade dos eventos.

A velocidade refere-se a mudanças de um parâmetro em um certo periodo de tempo, por exemplo uma boçoroca avança 100 metros em um período de um ano.

O espaço, similarmente ao tempo, é uma seqüência de locações medidas em incrementos iguais. Geralmente assume-se um espaço euclidiano tridimensional, com três eixos ortogonais $X Y Z$. A taxa de variação em $Z$, que usualmente está associada à altura, ao longo de uma distância, em $X$ ou em $Y$, é denominada declividade. 
A atuação dos processos ocorre com taxas (velocidades) variáveis, que podem ou não ser percebidas ao se observar um processo durante um periodo pequeno de tempo, porque as forças envolvidas são de pequena magnitude, ou porque não operam por um período de tempo suficiente. Caso a natureza, ou taxa de atuação, do processo se modifique, pode ocorrer alteração nos produtos observados, por exemplo, a passagem de uma enchente, implica na percepção de uma rápida modificação do regime e volume de chuvas, ou o intemperismo observado como resultado do ataque químico e físico.

Infante Jr. e Fornasari Filho (1998), descrevem que os principais processos de dinâmica superficial que modificam a paisagem estão relacionados às forças atuantes na superfície da Terra. Dentre estas forças destacam: a gravidade, as marés, a radiação solar e o calor interno. Diversos agentes podem estar envolvidos na geração do processo (água, vento, gelo), que são agrupados genericamente como erosão. $\mathrm{O}$ desgaste mecânico realizado pelos ventos ou rios, por meio das partículas que carregam, é chamado de abrasäo, enquanto que o desgaste químico é chamado de corrosão.

Os principais processos de dinâmica superficial que podem ser reconhecidos na área de estudo são: erosão, movimentos de massa, assoreamento, inundação e subsidências e colapsos.

\subsubsection{Erosão}

A erosão constitui o processo de desagregação e remoção de partículas de solo ou de fragmentos e partículas de rocha, pela ação combinada da gravidade com a água, vento, gelo e organismos (plantas e animais) (Salomão e Iwasa, 1995 apud Infante Jr. e Fornasari Filho, 1998).

Infante Jr. e Fornasari Filho (1998) descrevem os mecanismos que atuam durante a deflagração do processo erosivo pelas chuvas:

- impacto das chuvas, que provoca a desagregação das partículas;

- remoção e transporte pelo escoamento superficial;

- deposição dos sedimentos produzidos, formando depósitos de assoreamento.

\subsubsection{Tipos de erosão pela água}

A erosão pode se desenvolver em condições de equilíbrio com a formação do solo, sendo então denominada erosão natural ou geológica, e erosão acelerada ou 
antrópica, cuja intensidade é superior à da formação do solo, não permitindo a sua recuperação natural.

A atuação do escoamento superficial em encostas desprotegidas, de cobertura vegetal, ou antropizadas, pode resultar em dois tipos de erosão, que dependem também do tipo de escoamento:

- Erosão laminar ou erosão em lençol: causada pelo escoamento difuso das águas das chuvas, resultando na remoção progressiva e uniforme dos horizontes superficiais do solo;

- Erosão linear: causada pela concentração das linhas de fluxo das águas de escoamento superficial, resultando em pequenas incisões na superfície do terreno, em forma de sulcos, que pode evoluir, por aprofundamento, para ravinas.

\subsubsection{Boçorocas}

Infante Jr. e Fornasari Filho (1998) descrevem ainda que caso a erosão se desenvolva por influência não somente das águas superficiais, mas também dos fluxos d'água subsuperficiais, em que se inclui o lençol freático, configura-se o processo mais conhecido como voçoroca ou boçoroca, com o desenvolvimento da erosão interna ou entubamento (piping).

Salomão e Iwasa (1995) apud Infante Jr. e Fornasari Filho (1998) destacam que na boçoroca ocorrem diversos fenômenos: erosão superficial, erosão interna, solapamentos, desabamentos e escorregamentos, que se conjugam e conferem a esse tipo de erosão características como a rápida evolução e seu acelerado poder destrutivo.

Infante Jr. e Fornasari Filho (1998) descrevem que entre os principais condicionantes associados à formação de erosões lineares profundas estão os fatores antrópicos, como o desmatamento e formas de uso e ocupação do solo (agricultura, obras civis, urbanização, etc.) inadequados, associados a fatores naturais como a chuva, cobertura vegetal, relevo, tipos de solo e o substrato rochoso.

As boçorocas rurais se desenvolvem nas áreas de pastagens e culturas de má cobertura, sob manejo inadequado, sendo produto de ravinamentos, iniciados nas linhas de concentração das águas pluviais, ao longo de trilhas de gado, cercas, valas de demarcação, linhas de plantio e nos locais de descarga das águas pluviais de estradas vicinais. 


\subsubsection{Movimentos de massa}

Cruden (1990) apud Augusto Filho (1994) define os movimentos gravitacionais de massa genericamente como escorregamentos, ou movimentos de massa, rocha, solo e detritos, encosta abaixo. A tabela abaixo apresenta as principais caracteristicas dos movimentos gravitacionais de massa associados à encostas, agrupando estes processos em quatro grandes classes: rastejos (creep), escorregamentos (slides), quedas (falls) e corridas (flows), segundo Augusto Filho (1992) apud Augusto Filho (1994).

Tabela 4.2 - Características principais dos grandes grupos de processos de escorregamento no lato sensu (Augusto Filho, 1992).

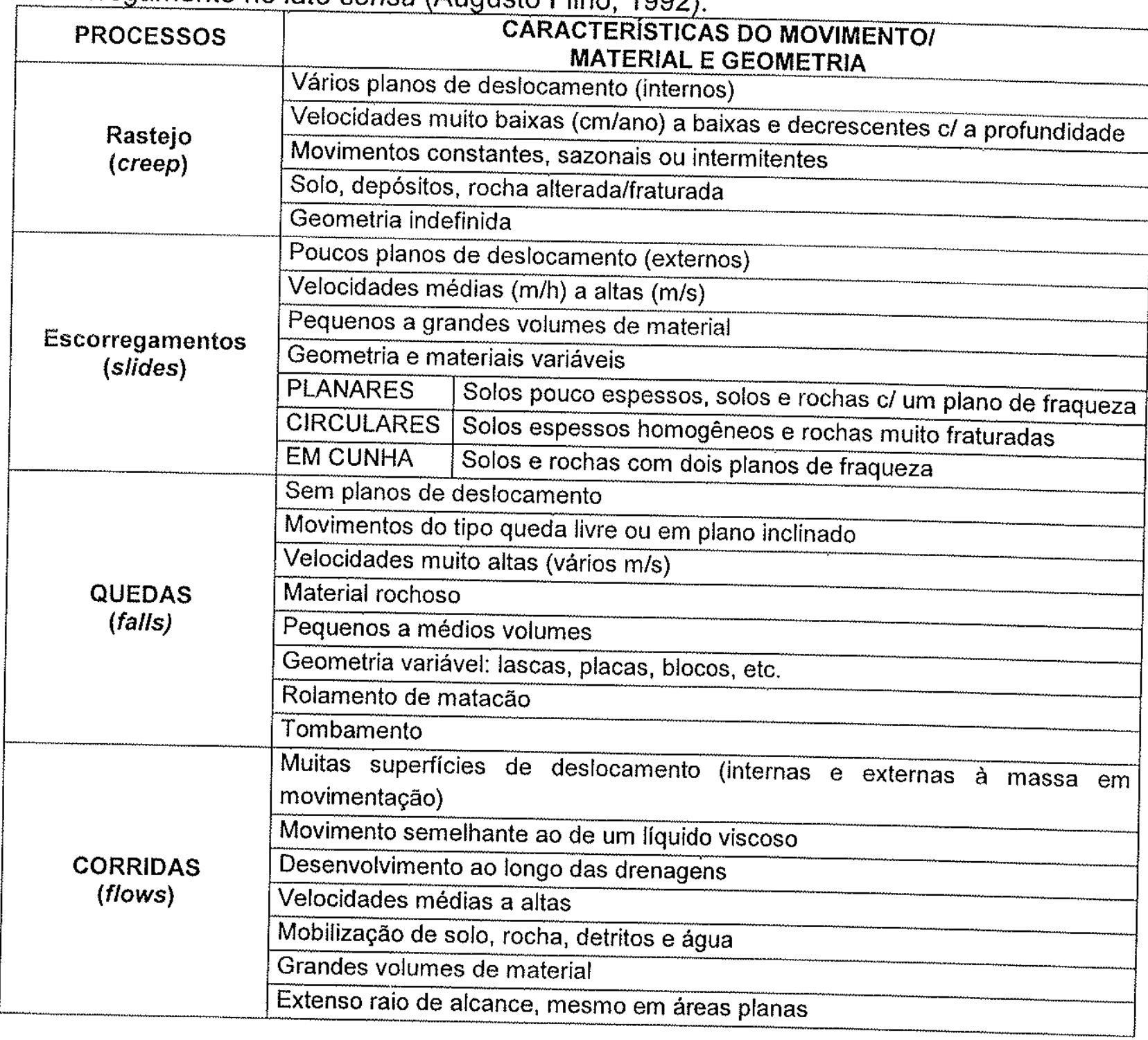

Nos itens seguintes é feita uma pequena sintese de cada processo seguindo Augusto Filho (1994). 


\subsubsection{Rastejos}

Consiste em um conjunto de movimentos muito lentos ( $\mathrm{mm}$ a $\mathrm{cm} / \mathrm{ano}$ ) que não apresentam uma superficie de ruptura marcante, tampouco geometria bem definida. As taxas de deslocamento decrescem gradualmente com a profundidade.

Os rastejos atuam sobre horizontes superficiais de solo, bem como em horizontes de transição solo/rocha e até mesmo em rocha. Apesar das baixas velocidades de deslocamento, podem causar danos econômicos (principalmente quando associados a depósitos de tálus) em obras civis e áreas urbanas em encostas, podendo ainda evoluir para escorregamentos.

\subsubsection{Escorregamentos}

Os escorregamentos englobam uma série de processos de instabilização, onde o mecanismo que induz ao processo é bem caracterizado, através da existência de alguns planos de movimentação bem distintos e externos a massa instabilizada. Apresentam velocidade de deslocamento média a alta $(\mathrm{m} / \mathrm{h}$ a $\mathrm{m} / \mathrm{s})$.

Os volumes instabilizados podem ser prontamente identificados, e podem envolver solo, saprolito, rocha e depósitos coluvionares e de tálus. São subdivididos de acordo com o mecanismo de ruptura, geometria e material que mobilizam.

As diversas categorias de escorregamento stricto sensu constituem-se nos processos de instabilização que mais causam danos socio-econômicos às diversas formas de uso e ocupação das áreas de encostas e adjacências.

A Tabela 4.3 apresenta os principais agentes e causas dos escorregamentos.

Tabela 4.3 - Principais agentes e causas dos escorregamentos (Guidicini e Nieble, 1976, apud Augusto Filho, 1994).

\begin{tabular}{|c|c|c|c|c|c|}
\hline \multicolumn{3}{|c|}{ AGENTES } & \multicolumn{3}{|c|}{ CAUSAS } \\
\hline Predisponentes & \multicolumn{2}{|c|}{ Efetivos } & Internas & Externas & Intermediárias \\
\hline $\begin{array}{c}\text { Complexo } \\
\text { geológico, } \\
\text { morfológico e } \\
\text { climático- } \\
\text { hidrológico; } \\
\text { gravidade, calor } \\
\text { solar, } \\
\text { vegetação. }\end{array}$ & $\begin{array}{l}\text { Pluviosidade, erosão } \\
\text { pela água e vento, } \\
\text { congelamento e } \\
\text { degelo, variação de } \\
\text { temperatura, } \\
\text { dissolução química, } \\
\text { ação de fontes e } \\
\text { mananciais, } \\
\text { oscilação do nivel de } \\
\text { lagos e marés e do } \\
\text { lençol freático, ação } \\
\text { de animais e } \\
\text { humana, inclusive } \\
\text { desflorestamento }\end{array}$ & $\begin{array}{c}\text { Chuvas } \\
\text { itensas, fusão } \\
\text { do gelo e } \\
\text { neves, erosão, } \\
\text { terremotos, } \\
\text { ondas, vento, } \\
\text { açăo do } \\
\text { homem. }\end{array}$ & $\begin{array}{c}\text { Efeito das } \\
\text { oscilações } \\
\text { térmicas; } \\
\text { redução dos } \\
\text { parâmetros } \\
\text { de resistência } \\
\text { por } \\
\text { intemperismo. }\end{array}$ & $\begin{array}{l}\text { Mudanças na } \\
\text { geometria do } \\
\text { sistema; efeitos } \\
\text { de vibraçōes; } \\
\text { mudanças } \\
\text { naturais na } \\
\text { inclinação das } \\
\text { camadas. }\end{array}$ & $\begin{array}{c}\text { Elevaçāo do nível } \\
\text { piezométrico em } \\
\text { massas } \\
\text { homogêneas; } \\
\text { elevação da } \\
\text { coluna d'água em } \\
\text { descontinuidades; } \\
\text { rebaixamento } \\
\text { rápido do lençol } \\
\text { freático; erosão } \\
\text { subterrânea } \\
\text { retrogressiva } \\
\text { (piping); } \\
\text { diminuição do } \\
\text { efeito da coesäo } \\
\text { aparente. }\end{array}$ \\
\hline
\end{tabular}




\subsection{Escorregamentos induzidos}

Os escorregamentos são ditos induzidos quando ocorrem devido à ação antrópica, através da execução de cortes/aterros inadequados, da concentração de águas pluviais e servidas, da retirada da cobertura vegetal, etc. Muitas vezes estes escorregamentos mobilizam materiais produzidos pela própria ocupação (aterros, lixos, entulhos, etc.).

\subsection{Escorregamentos planares}

Os escorregamentos planares ou translacionais em solo são processos muito freqüentes nas encostas serranas brasileiras, ocorrendo predominantemente em solos pouco desenvolvidos das vertentes com altas declividades. Sua geometria caracterizase por uma pequena espessura e forma retangular estreita. A associação com solos saprolíticos, saprolitos e rocha, também pode ser observada, condicionados principalmente por planos de fraqueza desfavoráveis à estabilidade, relacionados a estruturas geológicas diversas (foliação, xistosidade, fraturas e falhas).

\subsection{Escorregamentos circulares}

Os escorregamentos circulares ou rotacionais apresentam superficies de deslizamento curvas, sendo comum a ocorrência de uma série de rupturas combinadas e sucessivas. Estão associados a aterros, pacotes de solo ou depósitos mais espessos, rochas sedimentares ou cristalinas intensamente fraturadas, possuindo um raio de alcance relativamente menor que os escorregamentos planares.

\subsection{Escorregamentos em cunha}

Os escorregamentos em cunha estão associados a saprolitos e maciços rochosos, em que a existência de dois planos de fraqueza desfavoráveis à estabilidade condiciona o deslocamento ao longo do eixo de intersecção destes planos. Estes processos são mais comuns em taludes de corte, ou em encostas que sofreram algum processo natural de desconfinamento, como erosão ou escorregamentos.

Os solapamentos também podem ser entendidos como um tipo de escorregamento, cuja deflagração e evolução está diretamente relacionada à erosão fluvial, marinha, ravinas ou boçorocas. 


\subsubsection{Quedas}

As quedas constituem no destacamento de materiais rochosos diversos, de volumes variáveis, em encostas muito ingremes, num movimento tipo queda livre, ou em plano inclinado (rolamento de matacões). Estes processos possuem velocidades muito altas (vários $\mathrm{m} / \mathrm{s}$ ) e podem atingir grandes distâncias.

Nos tombamentos a queda se dá a partir da rotação de um bloco da encosta /talude em torno de um eixo de apoio. Estes processos estão condicionados a existência de planos de fraqueza subverticais no maciço rochoso.

Os processos de queda apresentam forte condicionante litológico e estrutural, e a sua deflagração pode estar intimamente associada a processos erosivos, como na queda de detritos em taludes de rochas sedimentares, ou rolamento de matacões em rochas graníticas.

\subsubsection{Corridas}

As corridas de massa podem ser descritas como o conjunto de movimentos gravitacionais de massa de grandes dimensões que se movimentam na forma de escoamento. São fenômenos muito menos freqüentes do que os escorregamentos, porém podem provocar estragos muito maiores, devido ao seu grande poder destrutivo e extenso raio de alcance, mesmo em áreas planas.

Os mecanismos de geração das corridas de massa podem ser agrupados em dois tipos básicos:

- origem primária: ocorre a formação de corridas pela transformação de escorregamentos em solo, através dos fenômenos de liquefação espontânea. Neste modelo a corrida teria inicio nas encostas ou nas vertentes das drenagens principais da bacia hidrográfica;

- origem secundária: a formação de corridas nas drenagens principais se dá a partir da remobilização de detritos acumulados no leito, por barramentos naturais, acrescidos do material oriundo de escorregamentos nas encostas e torrentes de água geradas na bacia.

\subsubsection{Assoreamento}

Segundo Infante Jr. e Fornasari Filho (1998) o assoreamento consiste na acumulação de sedimentos (partículas sólidas) em meio aquoso ou aéreo, ocorrendo quando a força do agente transportador natural (curso d'água, vento) é superada pela força da gravidade, ou quando a supersaturação do meio permite a deposição de 
partículas sólidas. Nos corpos d'água (mares, rios, lagos, etc.), os sedimentos ou partículas são provenientes do material transportado pelo vento, pelo escoamento superficial ou da erosão das margens. Os sedimentos podem ser transportados em suspensão, por arraste ou saltação, depositando-se quando ocorrem condições favoráveis para a sedimentação.

A intensificação destes processos como resultado de atividades antrópicas está diretamente associado ao aumento da erosão pluvial, por práticas agrícolas inadequadas e infra-estrutura precária de urbanização, bem como pela modificação da velocidade de cursos d'água por barramentos, desvios, etc., que estão associados à intensificação da deposição acarretando no assoreamento de corpos d'água.

\subsubsection{Inundação}

A inundação corresponde ao processo de extravasamento das águas de um curso d'água para as áreas marginais, quando a vazão a ser escoada é superior à capacidade de descarga da calha (Infante Jr. e Fornasari Filho, 1998), ou seja, consiste na elevação do nível d'água da drenagem ou rio, acima do seu nivel médio.

Segundo Baker et al. (1988) apud Infante Jr. e Fornasari Filho (1998) a inundação está normalmente associada à enchente ou cheia (acréscimo na descarga por certo período de tempo), que pode ser intensificada devido ao assoreamento de canal, barramentos ou remansos. O assoreamento estaria intensificando o processo de deposição de sedimentos e diminuindo a capacidade de armazenamento do canal, o que estaria relacionado aos barramentos que promovem a retenção de material e o entulhamento de drenagens. Os remansos seriam resultantes do alargamento da calha dos cursos d'água, promovendo a queda de energia de transporte, favorecendo a deposição de sedimentos e o comprometimento do volume de armazenamento do canal. A inundação pode ser considerada como uma cheia que extravasa o leito menor do rio ou drenagem, alcançando o seu leito maior ou planície de inundação conforme ilustrado na Figura 4.1.

Infante Jr. e Fornasari Fitho (1998) destacam ainda a importância do tipo de cobertura presente na bacia de captação, que pode reduzir a significância da inundação ou potencializar inundações expressivas. A cobertura vegetal, por exemplo, com expressão em área, facilitaria a infiltraçäo das águas pluviais e atuaria como uma barreira ao escoamento, o que reduziria a quantidade de água imediatamente disponibilizada às calhas dos rios. Outros tipos de coberturas, como aterros e asfalto, ao impermeabilizarem ou diminuirem a permeabilidade de solos tendem a aumentar o 
escoamento superficial e, conseqüentemente, a quantidade de água pluvial que chega às calhas de rios, contribuindo para inundações expressivas.

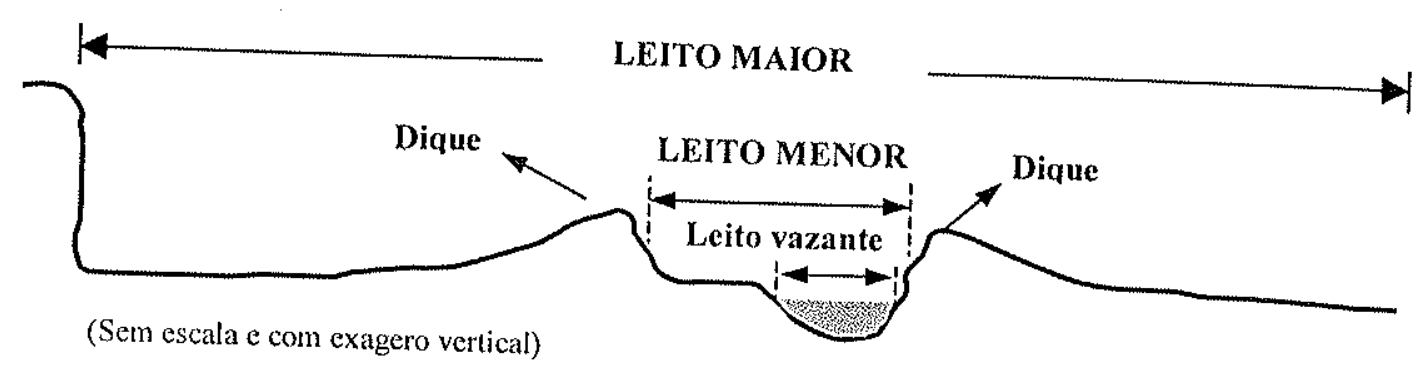

Figura 4.1 - Seção de um rio ou drenagem com os principais tipos de leito fluvial
(Christofoletti, 1981).

A Tabela 4.4 apresenta os principais condicionantes naturais e antrópicos indutores das inundações. Tabela 4.4 - Principais fatores/condicionantes naturais e ações antrópicas indutoras
das inundações (IPT, 1999).

\begin{tabular}{|c|c|}
\hline FATORES/CONDICIONANTES NATURAIS & AÇÕES ANTRÓPICAS INDUTORAS \\
\hline $\begin{array}{l}\text { Chuvas: intensidade e duraçäo } \\
\text { Planícies de inundação } \\
\text { Rupturas negativas de declive: bermas, terraços, } \\
\text { patamares, etc. } \\
\text { Baixa declividade } \\
\text { Cabeceiras de drenagem } \\
\text { Lençol freático raso } \\
\text { Marés altas } \\
\text { Grau de circularidade das bacias } \\
\text { Densidade de drenagem na bacia } \\
\text { Capacidade de escoamento (assoreamento, } \\
\text { soleiras, estreitamentos do canal, etc.) } \\
\end{array}$ & $\begin{array}{l}\text { Eliminação da cobertura vegetal } \\
\text { Impermeabilização (aumento do escoamento } \\
\text { superficial) } \\
\text { Estrangulamento artificial do leito menor e maior } \\
\text { (estruturas mal dimensionadas, lixo, etc.) } \\
\text { Construção de reservatórios (impactos a } \\
\text { montante e a jusante) }\end{array}$ \\
\hline
\end{tabular}

\subsubsection{Subsidências}

O processo de subsidência consiste na deformação ou deslocamento de direção essencialmente vertical descendente, manifestando-se por afundamento do terreno. 0 colapso, que corresponde a uma movimentação brusca do terreno, também pode ser incluido nesta definição tendo em mente que é um processo muito mais rápido do que a subsidência (Infante Jr. e Fornasari Filho, 1998).

Os mesmos autores definem ainda que o processo de subsidência pode ocorrer por causas naturais, como a dissolução de rochas (carstificação) como calcários, 
dolomitos, gipsita, sal; acomodação de camadas do substrato ocasionado pelo peso ou pequena movimentação segundo planos de falha, entre outros. As subsidências aceleradas pela ação humana ocorrem com bastante freqüência, como em decorrência do bombeamento de águas subterrâneas e recalques por acréscimo de peso devido a obras e estruturas. Estes casos podem adquirir particular importância em terrenos cársticos.

\subsection{Análise de suscetibilidade}

A análise de suscetibilidade é a abordagem utilizada neste trabalho para a análise dos diversos temas compilados e organizados no banco de dados do município. Nessa abordagem foram desenvolvidas análises enfocando um conjunto de processos geológicos, definidos nos itens anteriores, que apresentam uma relação direta com o tipo de uso e ocupação do solo como fatores potencializadores do processo geológico.

A abordagem utilizada neste trabalho apresenta semelhanças com as abordagens técnico-operacionais empregadas nos Zoneamentos Geotécnicos e Ecológicos Econômicos e análise de fragilidade. Os itens seguintes apresentam uma breve introdução dos conceitos de cada abordagem e de como ele é operacionalizada. Os parâmetros de análise aqui descritos serviram como referência para as análises apresentadas no capítulo seguinte.

\subsubsection{Unidades territoriais básicas na geotecnia}

Vedovello e Mattos (1998) descrevem a grande variação de abordagens técnicooperacionais empregadas na obtenção de zoneamentos geotécnicos, ressaltando a forma bastante variada de métodos de determinação das unidades geotécnicas, denominações e limites de unidades resultantes.

Ross (1995) descreve a existência de dois procedimentos operacionais básicos utilizados na espacialização de informações geo-ambientais, seja na cartografia informatizada ou convencional:

a) Land systems: visa a geraçăo de produtos analitico-sintéticos, o que, segundo Vedovello e Mattos (1998) é chamado de análise integrada ou abordagem de Sistemas de Terrenos;

b) Análise multi-temática: caracteriza-se pela geração de produtos analíticos em uma primeira fase e de sintese, posteriormente; 
Ross (1995) e Vedovello e Mattos (1998) destacam que na abordagem integrada (Land Systems) são tomados como referencial de análise os padröes de fisionomia do terreno, ou padrões de paisagens, que individualizadas servem como referencial permitindo identificar diferentes unidades de terreno.

Essas unidades de terreno são tratadas como unidades básicas de compartimentação (UBCs) e devem passar por uma análise integrada de suas propriedades, características de elementos componentes, para que sejam avaliadas em termos de diagnósticos e prognósticos ambientais (Vedovello e Mattos,1998).

Ross (1995) afirma que este procedimento é bastante vantajoso quando aplicado para regiões ou territórios que já dispõem de razoável volume de informações de pesquisas anteriormente efetuadas, que serão enriquecidas pelos dados secundários adequadamente manipulados.

Vedovello e Mattos (1998) ressaltam ainda que essa abordagem permite a elaboração de um produto cartográfico único, cujos elementos ambientais (relevo, solo, geologia, vegetação, uso do solo) são analisados integradamente e individualizados em unidades que refletem limites concretos no espaço, facilitando açöes de planejamento territorial.

Vedovello e Mattos (1998) e Ross (1995) destacam ainda que a prática de ambos procedimentos tem apontado uma vantagem da abordagem integrada sobre a multi-temática em termos de custos, tempo e aplicabilidade.

Ross (1995) relata que as pesquisas ambientais que envolvem uma abordagem multi-temática são mais verticalizadas e geram uma multiplicidade de produtos cartográficos temáticos de características analiticas e em alguns casos de sintese.

Vedovello e Mattos (1998) definem a análise multi-temática como uma abordagem em que "...são elaborados produtos cartográficos de diferentes temas os quais são cruzados diretamente ou em associações especificas, sucessivamente, por vezes com atribuições de pesos, até se chegar a um mapa de sintese final" o que resultaria em "...uma multiciplidade de produtos e, em conseqüência, de concepções teóricas, metodológicas e técnico-operacionais típicas de cada tema cartografado (mapa geológico, mapa geomorfológico, mapa pedológico, etc). o que resultaria na "...perda da visão de integração entre os diferentes temas" e dificultaria o seu entendimento por planejadores e gestores ambientais, pois "...devido ao cruzamento de mapas para se chegar ao mapa de sintese final, a determinação de unidades geotécnicas reflete limites abstratos no espaço, dificultando a sua visualização...".

Vedovello e Mattos (1998) descrevem as abordagens técnico-operacionais empregadas na obtenção de zoneamentos geotécnicos utilizando as unidades básicas 
de compartimentação (UBCs). Nesse contexto definem o zoneamento geotécnico como "...delimitação de áreas (zonas) do terreno para as quais os elementos componentes do meio físico por elas compreendidos determinam condições geotécnicas semelhantes, e para as quais um comportamento geotécnico ou uma aptidão de uso possam ser indicados frente às diferentes atividades antrópicas ".

Nesse processo seguem três etapas básicas:

a) compartimentação do terreno (identificação de zonas com características e propriedades geológico-geotécnicas homogêneas);

b) caracterização geotécnica (determinação das características e propriedades geotécnicas das áreas delimitadas);

c) cartografia temática final ou de sintese (onde as unidades definidas nas etapas anteriores são analisadas e classificadas em termos de fragilidades e potencialidades relativas aos objetivos do zoneamento, e apresentadas na forma de diagnósticos e/ou prognósticos).

\subsubsection{Unidades territoriais básicas no ZEE (zoneamento ecológico econômico)}

Crepani et al. (1996), que apresentam um conjunto de técnicas para o Zoneamento Ecológico Econômico baseando-se na análise integrada, destacam que: "... O simples cruzamento de mapas temáticos ou de planos de informação, no caso dos sistemas de informações geográficas (S/G) gerando novos dados, sem o acréscimo de conhecimento que o especialista pode obter a partir da interpretação das imagens, estará desprezando informações de inestimável importância.."

Crepani et al. (1996) descrevem uma abordagem de análise integrada que utiliza imagens de satélite como referência para a interpretação das unidades territoriais básicas. Essas unidades são definidas sobre as imagens de satélite através da fotointerpretação dos seus elementos básicos: elementos de textura de relevo e de drenagem, e tonalidades de cinza ou matizes de cores.

As unidades territoriais básicas são separadas em "unidades de paisagem natural" e nos "polígonos de ação antrópica", que recebem um tratamento diferenciado devido à atuação humana que modifica as condições naturais e pode produzir, conforme as condições de ocupação, agressöes irreversiveis.

As unidades definidas anteriormente recebem uma avaliação quanto ao caráter de estabilidade, conforme os pressupostos teóricos de Tricart (1977), sintetizados na Tabela 4.5 . 
Tabela 4.5 - Valores de Estabilidade de Unidades de Paisagem

\begin{tabular}{|c|c|c|}
\hline Unidade & Relação pedogênese /morfogênese & Valor \\
\hline Estável & Prevalece a pedogênese & 1.0 \\
\hline Intermediária & Equilibrio entre pedogênese e morfogênese & 2.0 \\
\hline Instável & Prevalece a morfogênese & 3.0 \\
\hline
\end{tabular}

Fonte: Modificado de Tricart, 1977, apud Crepani 1996

Cada unidade territorial básica é analisada quanto as características de geologia, geomorfologia, pedologia e uso da terra/cobertura vegetal, conforme apresentado nas Tabelas 4.6, 4.7, 4.8 e 4.9, respectivamente. A classificação final de cada unidade territorial é o resultado da média aritmética das pontuações em cada tema.

Tabela 4.6 - Valores de Estabilidade/Vulnerabilidade (EN) para as Unidades Litológicas.

\begin{tabular}{|c|c|}
\hline LITOLOGIA & EN \\
\hline Quartzitos ou metaquartzitos & 1,0 \\
\hline Riólito, Granito, Dacito & 1,1 \\
\hline Granodiorito, Quartzo Diorito, Granulitos & 1,2 \\
\hline Migmatitos, Gnaisses & 1,3 \\
\hline Fonólito, Nefelina Sienito, Traquito, Sienito & 1,4 \\
\hline Andesito, Diorito, Basalto & 1,5 \\
\hline Anortosito, Gabro, Peridotito & 1,6 \\
\hline Milonitos, Quartzo muscovita, Biotita, Clorita xisto & 1,7 \\
\hline Piroxenito, Anfibolito Kimberlito, Dunito & 1,8 \\
\hline Hornblenda, Tremolita, Actinolita xisto & 1,9 \\
\hline Estaurolita xisto, Xistos granatiferos & 2,0 \\
\hline Filito, Metassiltito & 2,1 \\
\hline Ardósia, Metargilito & 2,2 \\
\hline Mármores & 2,3 \\
\hline Arenitos quartzosos ou ortoquartzitos & 2,4 \\
\hline Conglomerados, Subgrauvacas & 2,5 \\
\hline Grauvacas, Arcózios & 2,6 \\
\hline Siltitos, Argilitos & 2,7 \\
\hline Folhelhos & 2,8 \\
\hline Calcários, Dolomitos, Margas, Evaporitos & 2,9 \\
\hline
\end{tabular}

Fonte: Crepani et al. (1998) apud Sousa (1998). 
Tabela 4.7 - Valores de estabilidade/vulnerabilidade para a dimensão interfluvial média para locais que dispõem de cartas topográficas em escala menor ou igual a 1:25.000.

\begin{tabular}{|c|c|c|c|c|c|}
\hline $\begin{array}{c}\text { AMPLITUDE DO } \\
\text { INTERFLÚVIO } \\
(\mathbf{m})\end{array}$ & EN & $\begin{array}{c}\text { AMPLITUDE DO } \\
\text { INTERFLÚVIO }(\mathbf{m})\end{array}$ & EN & $\begin{array}{c}\text { AMPLITUDE DO } \\
\text { INTERFLÚVIO (m) }\end{array}$ & EN \\
\hline$>5000$ & 1,0 & $3250-3500$ & 1,7 & $1500-1750$ & 2,4 \\
\hline $4750-5000$ & 1,1 & $3000-3250$ & 1,8 & $1250-1500$ & 2,5 \\
\hline $4500-4750$ & 1,2 & $2750-3000$ & 1,9 & $1000-1250$ & 2,6 \\
\hline $4250-4500$ & 1,3 & $2500-2750$ & 2,0 & $750-1000$ & 2,7 \\
\hline $4000-4250$ & 1,4 & $2250-2500$ & 2,1 & $500-750$ & 2,8 \\
\hline $3750-4000$ & 1,5 & $2000-2250$ & 2,2 & $250-500$ & 2,9 \\
\hline $3500-3750$ & 1,6 & $1750-2000$ & 2,3 & $<250$ & 3,0 \\
\hline
\end{tabular}

Fonte: Crepani et al. (1998) apud Sousa (1998).

Tabela 4.8 - Valores de estabilidade/vulnerabilidade para as classes de solos.

\begin{tabular}{|c|c|}
\hline CLASSE DE SOLO & $\mathrm{E} / \mathrm{V}$ \\
\hline Latossolo Amarelo & 1,0 \\
\hline Latossolo Vermelho-Amarelo & 1,0 \\
\hline Latossolo Vermelho-Escuro & 1,0 \\
\hline Latossolo Roxo & 1,0 \\
\hline Latossolo Bruno & 1,0 \\
\hline Latossolo Húmico & 1,0 \\
\hline Latossolo Bruno-Húmico & 1,0 \\
\hline Podzólico Amarelo & 2,0 \\
\hline Podzólico Vermelho-Amarelo & 2,0 \\
\hline Podzólico Vermelho-Escuro & 2,0 \\
\hline Terra Roxa Estruturada & 2,0 \\
\hline Bruno Não-Cálcico & 2,0 \\
\hline Brunizém & 2,0 \\
\hline Brunizém Avermelhado & 2,0 \\
\hline Planossolo & 2,0 \\
\hline Cambissolos & 2,5 \\
\hline Solos Litólicos & 3,0 \\
\hline Solos Aluviais & 3,0 \\
\hline Regossolo & 3,0 \\
\hline Areia Quartzosa & 3,0 \\
\hline Vertissolo & 3,0 \\
\hline Solos Orgânicos & 3,0 \\
\hline Solos Hidromórficos & 3,0 \\
\hline Glei Húmico & 3,0 \\
\hline Glei Pouco Húmico & 3,0 \\
\hline Plintossolo & 3,0 \\
\hline Laterita Hidromórfica & 3,0 \\
\hline Solos Concrecionários Lateríticos & 3,0 \\
\hline Rendzinas & 3,0 \\
\hline Afloramento Rochoso & 3,0 \\
\hline
\end{tabular}

Fonte: Crepani et al. (1998) apud Sousa (1998). 
Tabela 4.9 - Valores de estabilidade/vulnerabilidade para as diferentes formações florestais.

\begin{tabular}{|c|c|}
\hline ECOSSISTEMA & EN \\
\hline Floresta Ombrófila Densa & 1,0 \\
\hline Floresta Ombrófila Aberta & 1,2 \\
\hline Floresta Ombrófila Mista & 1,3 \\
\hline Floresta Estacional Semidecidual & 1,6 \\
\hline Floresta Estacional Decidual & 2,2 \\
\hline Vegetação secundária & $X^{2}$ \\
\hline Cultura perene & 2,7 \\
\hline Cultura anual & 2,9 \\
\hline Solo exposto & 3,0 \\
\hline$X^{2} O E N$ depende do tipo de floresta, do porte e do grau de cobertura do terreno
\end{tabular}

Fonte: Crepani et al. (1998) apud Sousa (1998).

\subsubsection{Análise de fragilidade}

A abordagem empregada por Ross (1994), na geração de cartas de Fragilidade, baseia-se no conceito de Unidades Ecodinâmicas de Tricart (1977) que define uma análise integrada dos elementos do meio-físico que relacionados geram um produto sintético retratando as características da área.

A análise de fragilidade, nessa abordagem, utiliza os seguintes fatores: relevo, solo, uso da terra, pluviosidade e geologia. A relação entre essas cartas permite a produção de um produto cartográfico síntese, que classifica e qualifica a área estudada em Unidades Ecodinâmicas Estáveis ou Instáveis com diferentes graus de instabilidade potencial e emergente.

A análise do ambiente através dessa abordagem parte do pressuposto de que na natureza as trocas de energia e matéria se processam através de relações em equilibrio dinâmico. A alteração desse equilibrio ocorre quando o homem interfere nos diversos componentes da natureza, gerando estados de desequilibrio temporários ou até permanentes (Ross, 1994).

Tricart (1977, apud Ross 1994) definiu então que os ambientes que estão em equilíbrio dinâmico são estáveis e aqueles que estão em desequilibrio são instáveis. Ross (1990 apud Ross, 1994) introduziu critérios complementares para melhor definição das Unidades Ecodinâmicas no contexto do Planejamento Ambiental. As Unidades Ecodinâmicas Instáveis foram definidas como áreas em que as intervenções antrópicas modificaram intensamente os ambientes naturais através dos desmatamentos e práticas de atividades econômicas diversas, enquanto que as Unidades Ecodinâmicas Estáveis são as que estão em equilíbrio dinâmico e foram poupadas da ação humana, encontrando-se portanto em seu estado natural. 
Ross (1990) amplia o conceito de Unidades Ecodinâmicas Estáveis relacionando a possibilidade de apresentarem Instabilidade Potencial qualitativamente previsivel frente as suas características naturais e a sempre possivel inserção antrópica. A Tabela 4.10 apresenta a classificação empregada por Ross (1990).

Tabela 4.10 - Classificação proposta por Ross (1990) na hierarquização das unidades ecodinâmicas de Tricart (1977).

\begin{tabular}{|c|c|c|c|}
\hline \multirow{2}{*}{ UNIDADES ECODINÂMICAS (Tricart, 1977) } & \multicolumn{3}{|c|}{ Ross (1990) } \\
\hline & \multicolumn{3}{|c|}{ Classificação } \\
\hline \multirow{5}{*}{ INSTÁVEIS } & \multirow{5}{*}{$\begin{array}{l}\text { Unidades } \\
\text { Ecodinâmicas } \\
\text { Instáveis ou de } \\
\text { Instabilidade } \\
\text { Emergente }\end{array}$} & 1 & Muito fraca \\
\hline & & 2 & Fraca \\
\hline & & 3 & Média \\
\hline & & 4 & Forte \\
\hline & & 5 & Muito forte \\
\hline \multirow{5}{*}{ ESTÁVEIS } & \multirow{5}{*}{$\begin{array}{c}\text { Unidades } \\
\text { Ecodinâmicas de } \\
\text { Instabilidade } \\
\text { Potencial }\end{array}$} & 1 & Muito fraca \\
\hline & & 2 & Fraca \\
\hline & & 3 & Média \\
\hline & & 4 & Forte \\
\hline & & 5 & Muito forte \\
\hline
\end{tabular}

\subsubsection{Procedimentos operacionais}

A execução da análise empírica de fragilidade exige produtos cartográficos temáticos de geomorfologia, geologia, pedologia, climatologia e uso da terra/vegetação (Ross, 1994).

Cada tema é tratado separadamente e pode seguir duas abordagens, conforme a escala de trabalho. Para análise em escalas médias e pequenas (1:50.000 até 1:250.000) utilizam-se como base de informação os Padrões de Formas com a rugosidade topográfica ou os Índices de Dissecação do Relevo, expressos através da Matriz dos Índices de Dissecação. Em escalas de maior detalhe (1:25.000 até 1:2.000), utilizam-se as formas de vertentes e as Classes de Declividade.

Spörl (2001) utilizou as duas abordagens para análise da fragilidade natural descritas nos itens abaixo, que sintetizam como são tratados cada um dos temas empregados na análise de fragilidade segundo Ross $(1990,1992,1994)$. 


\subsubsection{Fragilidade potencial natural (índices de dissecação do relevo)}

Os levantamentos básicos de solos, índices de dissecação do relevo, cobertura vegetal e análise climatológica são empregados nessa abordagem que propõe uma hierarquização em cinco classes de agrupamentos descritos nos itens seguintes.

\subsection{Solos}

A hierarquização dos tipos de solos segue a proposta de Ross (1994) apresentada na Tabela 4.11, que considera as características de textura, estrutura, plasticidade, grau de coesão das partículas e profundidade/espessura dos horizontes superficiais e subsuperficiais. A hierarquização é feita em cinco categorias.

Tabela 4.11 - Classes de Fragilidade dos solos em cinco categorias (Ross, 1994).

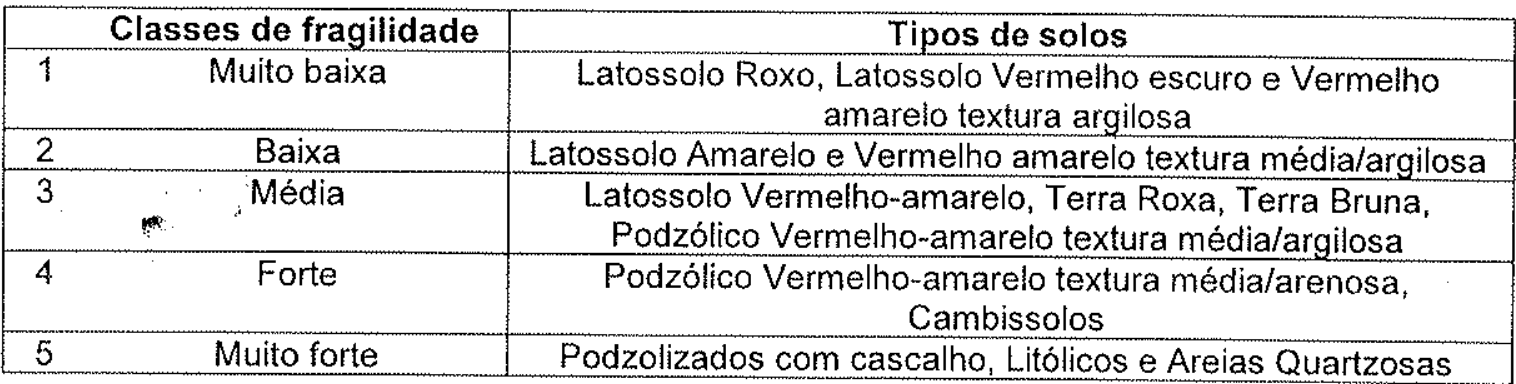

\subsubsection{2 Índices de dissecação do relevo}

A matriz desenvolvida por Ross (1992), baseia-se na relação densidade de drenagem/dimensão interfluvial média, e define categorias de influência muito fraca até muito forte, conforme a Tabela 4.12.

Tabela 4.12 - Matriz dos índices de dissecação do relevo (Ross, 1992).

\begin{tabular}{|c|c|c|c|c|c|}
\hline $\begin{array}{c}\text { Densidade de drenagem ou } \\
\text { dimensão Interfluvial } \\
\text { média (classes) }\end{array}$ & $\begin{array}{c}\text { Muito } \\
\text { grande } \\
(1)\end{array}$ & Grande & Média & Pequena & $\begin{array}{c}\text { Muito } \\
\text { pequena }\end{array}$ \\
\hline $\begin{array}{c}\text { médio dos vales (classes) } \\
\text { Muito fraco (1) } \\
(<40 \mathrm{~m})\end{array}$ & 11 & 12 & 13 & 14 & 15 \\
\hline $\begin{array}{c}\text { Fraco (2) } \\
(40 \text { a } 80 \mathrm{~m})\end{array}$ & 21 & 22 & 22 & 24 & 25 \\
\hline $\begin{array}{c}\text { Médio (3) } \\
(80 \text { a } 160 \mathrm{~m})\end{array}$ & 31 & 32 & 33 & 34 & 35 \\
\hline $\begin{array}{c}\text { Forte }(4) \\
(160 \text { a } 240 \mathrm{~m})\end{array}$ & 41 & 42 & 43 & 44 & 45 \\
\hline $\begin{array}{c}\text { Muito forte (5) } \\
(>\text { de } 240 \mathrm{~m})\end{array}$ & 51 & 52 & 53 & 54 & 55 \\
\hline
\end{tabular}

Fonte: Spörl (2001).

As categorias morfométricas são então classificadas quanto as classes de dissecação do relevo, conforme a Tabela 4.13. 
Tabela 4.13 - Classificação das categorias morfométricas (Ross, 1992).

\begin{tabular}{|c|c|c|}
\hline & joria hierárquica & Classes de dissecação do relevo \\
\hline 1 & Muito fraca & 11 \\
\hline 2 & Fraca & $21,22,12$ \\
\hline 3 & Média & $31,32,33,13,23$ \\
\hline 4 & Forte & $41,42,43,44,14,24,34$ \\
\hline 5 & Muito forte & $51,52,53,54,55,15,25,35,45$ \\
\hline
\end{tabular}

Fonte: Ross (1994).

\subsection{Uso da Terra / Cobertura vegetal}

A classificação proposta por Ross (1994) consiste na hierarquização dos graus de proteção que determinado tipo de cobertura oferece aos solos, conforme apresentado na Tabela 4.14.

Tabela 4.14 - Graus de proteçäo do solo segundo a cobertura vegetal (Ross, 1994).

\begin{tabular}{|c|c|c|}
\hline & lasses de fragilidade & Tipos de cobertura vegetal \\
\hline 1 & Muito alto & $\begin{array}{l}\text { Florestas/Matas naturais, florestas cultivadas } \\
\text { com biodiversidade }\end{array}$ \\
\hline 2 & Alto & $\begin{array}{l}\text { Formações arbustivas naturais com estrato } \\
\text { herbáceo denso, formaçöes arbustivas densas } \\
\text { (mata secundária, Cerrado Denso, Capoeira } \\
\text { Densa). Mata homogênea de Pinus densa. } \\
\text { Pastagens cultivadas com baixo pisoteio do } \\
\text { gado, cultivo de ciclo longo como o cacau }\end{array}$ \\
\hline 3 & Médio & $\begin{array}{l}\text { Cultivo de ciclo longo em curvas de } \\
\text { nivel/terraceamento como café, laranja com } \\
\text { forrageiras entre ruas, pastagens com baixo } \\
\text { pisoteio, silvicultura de eucaliptos com sub- } \\
\text { bosque de nativas }\end{array}$ \\
\hline 4 & Baixo & $\begin{array}{l}\text { Culturas de ciclo longo de baixa densidade (café, } \\
\text { pimenta do reino, laranja com solo exposto entre } \\
\text { ruas), culturas de ciclo curto arroz, trigo, feijāo, } \\
\text { soja, milho, algodão com cultivo em curvas de } \\
\text { nivel/terraceamento) }\end{array}$ \\
\hline 5 & Muito baixa a nula & $\begin{array}{l}\text { Areas desmatadas e queimadas recentemente, } \\
\text { solo exposto ao longo de caminhos e estradas, } \\
\text { terraplanagens, culturas de ciclo curto sem } \\
\text { práticas conservacionistas }\end{array}$ \\
\hline
\end{tabular}

Fonte: Ross (1994).

\subsection{Climatologia}

A distribuição e a intensidade das chuvas ao longo do ano são fatores decisivos no processo de intemperismo de rochas e solos, ou seja, são fundamentais para a análise da fragilidade ambiental. A categorização das características climatológicas é 
feita de acordo com a maior ou menor intensidade do efeito pluviométrico sobre os processos morfodinâmicos tendo como subsídio os principais domínios climáticos que ocorrem no território brasileiro (Spörl, 2001).

As categorias são definidas conforme a capacidade de interferência da estabilidade do ambiente. Estas categorias vão desde a classe de fragilidade muito baixa até a muito forte, conforme apresentado na Tabela 4.15 .

Tabela 4.15 - Niveis hierárquicos dos comportamentos pluviométricos (Spörl, 2001).

\begin{tabular}{|c|c|c|}
\hline & is hierárquicos & Caracteristicas pluviométricas \\
\hline 1 & Muito baixa & $\begin{array}{l}\text { Situaçāo pluviométrica com distribuiçăo regular ao longo do ano, com } \\
\text { volumes anuais não muito superiores a } 1000 \mathrm{~mm} / \text { ano }\end{array}$ \\
\hline 2 & Baixa & $\begin{array}{l}\text { Situação pluviométrica com distribuição regular ao longo do ano, com } \\
\text { volumes anuais não muito superipores a } 2000 \mathrm{~mm} / \mathrm{ano}\end{array}$ \\
\hline 3 & Média & $\begin{array}{c}\text { Situação pluviométrica com distribuição anual desigual, com periodos } \\
\text { secos entre } 2 \text { e } 3 \text { meses no inverno, e no verão com maiores } \\
\text { intensidades de dezembro a marco }\end{array}$ \\
\hline 4 & Forte & $\begin{array}{l}\text { Situação pluviométrica com distribuição anula desigual, com periodo } \\
\text { seco entre } 3 \text { e } 6 \text { meses, e alta concentração das chuvas no verão } \\
\text { entre novembro e abril quando ocorrem de } 70 \text { a } 80 \% \text { do total das } \\
\text { chuvas }\end{array}$ \\
\hline 5 & Muito forte & $\begin{array}{l}\text { Situação pluviométrica com distribuiçäo regular, ou não, ao longo do } \\
\text { ano, com grandes volumes anuais ultrapassando } 2500 \mathrm{~mm} / \mathrm{ano} \text { ou } \\
\text { ainda comportamentos pluviométricos irregulares ao longo do ano, } \\
\text { com episódios de chuvas de alta intensidade e volumes anuais } \\
\text { baixos, geralmente abaixo de } 900 \mathrm{~mm} / \text { ano (semi-árido) }\end{array}$ \\
\hline
\end{tabular}

Fonte: Spörl, 2001.

A associação de todas essas variáveis permite a classificação da fragilidade, que é feita utilizando-se os números arábicos que foram definidos em cada classificação. A combinação dessas classificações permite hierarquizar os graus de fragilidade natural. Por exemplo, o conjunto numérico 1111 representa uma área com relevo de dissecação muito fraca, solos de muito fraca erodibilidade, recobertos por mata e com uma situação pluviométrica regular com volumes próximos de 1000 $\mathrm{mm} / a n$. Enquanto que o conjunto numérico 5555 apresenta todas as variáveis desfavoráveis, como por exemplo, uma área com um relevo fortemente dissecado, com solos muito frágeis aos processos erosivos, desprovidos de cobertura vegetal, e ainda, com situações pluviométricas com distribuição irregular e volumes superiores a 2500 $\mathrm{mm}$ /ano.

Em sintese quanto maior for a associação numérica (relevo/ solos/ vegetação/ pluviosidade) maior o grau de fragilidade potencial na relação relevo-solo face aos processos erosivos de um lado, e a potencial perda de qualidade das águas de superfície de outro (Spörl, 2001).

A adaptação feita por Ross (1994), a partir da proposta de Tricart (1977), inclui na definição das Unidade Ecodinâmicas Estáveis diferentes graus de instabilidade 
potencial. Nessa classificação as áreas que apresentam uma cobertura vegetal densa (mata ou reflorestamento) são consideradas áreas em que a morfodinâmica atua em estado natural, predominando os processos de intemperismo físico-químico, com escoamento superficial lento e infiltração lenta, ou seja áreas em que se apresentam em equilíbrio dinâmico natural (Spörl, 2001).

As Unidades Ecodinâmicas Instáveis com diferentes graus de Instabilidade Emergente são aquelas cujas atividades humanas modificaram o estado de equilibrio dinâmico, áreas onde, as condições naturais de cobertura vegetal foram substituídas por pastagens, plantações, entre outras, o que permitiu a ação direta das chuvas sobre os solos gerando processos erosivos e perda de qualidade das águas superficiais pelo aporte de sedimentos.

\subsubsection{Fragilidade potencial natural (classes de declividade)}

Os procedimentos operacionais são os mesmos utilizados na abordagem com os índices de dissecação do relevo, contudo este é substituído pela análise das classes de declividade que passam a ser o fator de classificação de primeira importância. As classes de declividade comumente utilizadas em análises de processos do meio-físico, segundo Ross (1994) são apresentadas na Tabela 4.16, seguidas da hierarquização em 5 classes.

Tabela 4.16 - Intervalos de declividade utilizados na classificação.

\begin{tabular}{|lc|c|c|}
\hline & Categoria hierárquica & $\begin{array}{c}\text { Classes de } \\
\text { declividade (\%) }\end{array}$ & $\begin{array}{c}\text { Intervalos de declividade } \\
\text { comumente utilizados (\%) }\end{array}$ \\
\hline 1 & Muito fraca & $<6$ & $3-6$ \\
\hline 2 & Fraca & $6-12$ & $6-12$ \\
\hline 3 & Média & $12-20$ & $12-20$ \\
\hline 4 & Forte & $20-30$ & $20-30$ \\
\hline 5 & Muito forte & $>30$ & $>30$ \\
\hline
\end{tabular}

Fonte: Ross (1994). 


\section{CAPÍTULO 5 - BASE DE DADOS COMPILADA}

\subsection{Geologia}

Campanha $(1999,2000)$ adota a denominação de Supergrupo Açungui para o conjunto de rochas supracrustais de baixo a médio graus metamórficos ocorrentes na região, destacado do Embasamento ou Complexo Gnáissico-migmatítico, e das unidades associadas a pequenas bacias pull-apart tardias (seqüências molassóides).

O Supergrupo Açungui é subdividido em uma série de unidades dispostas lateralmente em faixas longilíneas de orientação NE. São elas: Grupo Itaiacoca, Formação Água Clara, Grupo Votuverava, Formação Capiru e Grupo Setuva. São reconhecidas subdivisões com empithamento e colunas estratigráficas internas a cada uma dessas unidades. A correlação entre estas unidades maiores é feita lateralmente, e não verticalmente.

A seguir é feita uma descrição das unidades representadas no mapa geológico do municipio de Iporanga (Figura 5.1), seguindo Campanha (1999, 2000).

\subsubsection{Formação Água Clara}

A Formação Água Clara (Marini et al. 1967, apud Campanha 1999, 2000) ocorre essencialmente na área do Complexo Granitóide Três Córregos, a grosso modo é limitada a noroeste com Grupo Itaiacoca através do lineamento de Itapirapuã, e a sudeste com o Grupo Votuverava através do Lineamento Quarenta Oitava. Corresponde a uma seqüência carbonática impura, com predomínio de rochas calciosilicáticas bandadas e metapelitos, mas também com ocorrência de metacalcários calcíticos acinzentados e anfibolitos. O grau metamórfico é em geral um pouco mais alto, chegando ao topo do grau fraco a início do médio, apresentando estilo deformacional mais intenso e por vezes metamorfismo termal sobreposto. Foi definida como topo do Açungui, posteriormente colocada para sua base, e atualmente tem sido considerada como correlata a unidades carbonáticas dos grupos Itaiacoca e Votuverava (Campanha, 1991, Spoladore, 1993, Reis Neto, 1994, Fassbinder, 1996).

\subsubsection{Grupo Votuverava}

As unidades do dominio central podem ser genericamente atribuídas à Formação Votuverava clássica (Bigarella e Salamuni 1958b), descrita aqui na categoria de Grupo e subdividida nos subgrupos Lajeado e Ribeira, mantendo-se as formações 
Córrego dos Marques, Iporanga e Perau como unidades isoladas, dentro do Grupo Votuverava.

A correlação da área tipo da Formação Votuverava clássica no estado do Paraná (Serra do Voturuvu) com as unidades ocorrentes no estado de São Paulo nos arredores da cidade de Iporanga já havia sido reconhecida por Barbosa (1948).

\subsubsection{Subgrupo Lajeado}

O Subgrupo Lajeado (Campanha et al. 1985, 1986) corresponde a uma plataforma carbonática de águas rasas, porém em geral não litorâneas e abertas para o oceano. Sobrepõem-se alternadamente a unidades clásticas terrígenas e carbonáticas, intrudidas na sua porção superior por um corpo grabóide, o Grabo de Apiaí. Sua subdivisão estratigráfica é reconhecida desde Barbosa (1941). Correponde à "faixa central de rochas carbonáticas" de Marini e Bigarella (1967), e à Formação Açungui III de Daitx et al. (1983) e do MMA/JICA (1981, 1982, 1983). A seção tipo é a estrada Apiai a Iporanga. É correlata à Formação Antinha no Paraná (Dias e Salazar Jr., 1987), da qual é separada fisicamente, ambas ocorrendo como lentes tectônicas regionais, desenvolvidas pelo sistema de zonas de cisalhamento transcorrentes.

\subsubsection{Formação Iporanga}

A porção superior do Grupo Votuverava é ocupada pela Formação Iporanga (Leonardos, 1934, Daitx, 1980, Campos Neto, 1983a, Campanha et al., 1985, 1986). No estado de São Paulo ocorre uma faixa estreita logo a sul do Lineamento da Figueira, sendo interrompida pelo Lineamento Ribeira. É equivalente no estado do Paraná ao Conglomerado Cerne de Bigarella et al. (1955) e à Seqüência Bromado de Fiori $(1990,1992)$. Caracteriza-se pela ocorrência de níveis e lentes de metabrechas e metaconglomerados polimíticos, com clastos de diversos tamanhos e litologias, matriz lamítica, em meio a metapelitos rítmicos predominantes. Tem recebido diversas interpretações em termos de paleoambiente: tilitos (Leonardos, 1934), turbiditos distais (Petri e Suguio, 1969), molassas (Daitx, 1980), wildflysh (Campanha et al., 1985, 1986), debris flow e turbiditos canalizados (Pires, 1988).

\subsubsection{Subgrupo Ribeira}

O Subgrupo Ribeira ocorre a sudeste do Lajeado, separado deste no estado de São Paulo pelo Lineamento da Figueira, e pelos lineamentos da Ribeira e Agudos Grandes quando adentra-se no estado do Paraná. O Subgrupo Ribeira corresponde às seqüências pelíticas finas (filíticas) e, em parte, vulcânicas, da Formação Votuverava 
clássica. Corresponde à Formação Perau no sentido ampliado de Chiodi Filho (1984) e Campanha et al. (1986, 1987), bem como às formações Açungui I e Il do MMA/JICA (1981, 1982, 1983).

A Série Ribeira foi definida por Leonardos (1941) como uma extensão da Formação Iporanga (Leonardos, 1934), descrevendo as seqüências que ocorrem ao longo do rio Ribeira a juzante da cidade de Iporanga. Esta denominação caiu em desuso, tendo sido retomada mais recentemente por Hasui (1986). Justifica-se aqui o retorno do nome Ribeira como uma subdivisão do Grupo Votuverava, com a hierarquia de subgrupo, pelo fato de constituir uma unidade mapeável e contínua através dos estados de São Paulo e Paraná, e pelo fato de que outras denominações são informais (e.g. formações Açungui I e II), definidas incorretamente (e.g. Formação São Sebastião) ou polêmicas quando estendidas além de sua área tipo (e.g. Formação Perau). Não havendo um nome consagrado, a denominação Ribeira tem prioridade.

O padräo deformacional em geral intenso, com dobramento isoclinal $\mathrm{e}$ transposição, por vezes total, do acamamento sedimentar torna complexo o processo de reconstrução da estratigrafia interna.

\subsubsection{Grupo Setuva}

A sul do Lineamento Lancinha ocorrem unidades metassedimentares mostrando em geral contatos tectônicos de baixo ângulo com o Complexo Gnáissico Migmatítico. No Paraná correspondem as formações Capiru e Setuva clássicas (Bigarella e Salamuni 1956a; b; 1958 a, b) e no estado de São Paulo ao Complexo Turvo-Cajati (Silva e Algarte $1981 \mathrm{a}, \mathrm{b}$ ).

A Seqüência Turvo-Cajati foi subdividida originalmente nas subseqüências Turvo Areado (micaxistos, paragnaisses, quartzitos, Capela do Cedro (mármores dolomíticos) e Cajati (filitos).

Seguindo a regra da prioridade, Campanha (2000) propõe a denominação de Grupo Setuva para o conjunto de metassedimentos de baixo a médio graus metamórficos (predominantemente micaxistos) abrangidos por essas unidades, mantendo-se destacada a Formação Capiru.

O chamado complexo Embu em São Paulo (Hasui e Sadowski, 1976), estendido até a região do Vale do Ribeira por Hasui e Oliveira (1984), é constituído essencialmente por xistos aluminosos, xistos feldspáticos e migmatitos de paleossoma xistoso. Pode ser considerado também como provável continuidade do Grupo Setuva a norte do Lineamento Ribeira/Cubatão. 


\subsubsection{Formação Capiru}

Da mesma forma que a Formação Itaiacoca, a Formação Capiru corresponde a uma seqüência plataformal de águas rasas e litorâneas, com alternâncias de pacotes carbonáticos, psamíticos e pelíticos. Fiori $(1990,1992)$ distingue as seqüências Juruqui (filitos avermelhados com intercalações menores de quatzitos) e Morro Grande (quartzitos e filitos alternados). Os mármores da Formação Capiru são predominantemente dolomíticos, maciços e silicosos, destacando-se pela presença de estromatólitos. Fiori et al. (1987a, b, c) demonstram relações de aloctonia entre esta formação e o embasamento, sendo suas seqüências basais fortemente afetadas por zonas de cisalhamento de baixo ângulo (empurrões). Sua diferenciação com relação ao Grupo Setuva em termos de estilo estrutural torna-se ambígua neste contexto, já que ambas são afetadas pelos mesmos eventos cisalhantes. Fiori (1987) sugere que as denominações Setuva e Capiru correspondam mais a unidades litotectônicas, do que unidades litoestratigráficas.

Campanha (1991), estudando a extensão das formações Capiru e Setuva em direção ao estado de São Paulo, sugere que a diferenciação entre ambas se dá mais em função do grau metamórfico, mais baixo para o Capiru, do que em função do estilo estrutural ou da associação de protólitos. Nesse sentido, levanta-se a hipótese de que os mármores dolomíticos brancos e maciços ocorrentes na área do Complexo TurvoCajati em São Paulo (Subseqüência Capela do Cedro, Silva e Algarte, 1981 a, b) e o Mármore da Tapagem sejam correlatos aos mármores da Formação Capiru.

O aumento do grau metamórfico, em conjunto com a deformação intensa de baixo ângulo, complica por vezes a separação do Grupo Setuva de seu embasamento.

\subsubsection{Complexos Gnáissico-migmatítico}

O Complexo Gnáissico-migmatítico constitui-se em um extenso conjunto de rochas gnáissico-migmatíticas, orto e paraderivadas, freqüentemente com intercalaçōes ectiníticas e de rochas mais resistentes à migmatização (mármores, quartzitos, anfibolitos, calciossilicáticas). Esse conjunto intermediário entre duas unidades mais basais e o Grupo Setuva foi denominado Complexo Gnáissicomigmatítico (Dantas et al., 1987) ou Complexo Atuba (Siga Jr. et al., 1995).

\subsubsection{Rochas Granitóides}

As rochas granitóides são classicamente divididas na região em dois grandes conjuntos, uma Suite Pós-Tectônica e uma Suite Sin-a Tardi-tectônica. 
A Suite Pós-tectônica, por vezes referida na literatura sobre a região como póscolisional ou anorogênica, é constituida por uma série de corpos circunscritos, claramente intrusivos, em geral pouco deformados, com idades na faixa de 600-500 Ma. São compostos por rochas em geral no campo dos granitos $3 a$, álcali-feldspato granitos e quartzo sienitos, fortemente diferenciados e com marcante tendência alcalina. Suas texturas são em geral isótropas equigranulares hipidiomórficas ou xenomórficas.

A Suíte Sin a Tardi-tectônica é constituída por três grandes batólitos alongados na direção NE e diversos corpos menores. São rochas com composição em geral no campo dos granitos $3 \mathrm{~b}$, granodioritos e quartzo monzonitos pouco diferenciados, com caráter cálcio-alcalino e idades entre 600 e 630 Ma. A textura predominante é porfiróide, com fenocristais de feldspato potássico imersos em matriz mais fina. A deformação é bastante variável, existindo rochas desde isótropas ou levemente foliadas até fortemente miloníticas. Por vezes apresentam contatos intrusivos, mas em grande parte apresentam contatos tectônicos com as encaixantes. Por suas características petrográficas, geoquímicas e isotópicas têm sido interpretados nos últimos anos como prováveis raizes de um arco magmático continental do tipo andino (Theodorovicz et al., 1988, Chiodi Filho et al., 1989, Wernick 1990, Gimenez Filho, 1993, Reis Neto, 1994). No Domínio Apiaí da Faixa Ribeira ocorrem três grandes maciços granitóides desta natureza: Cunhaporanga, Três Córregos e Agudos Grandes, em boa parte ainda não suficientemente conhecidos. O Maciço de Itaoca pode ser acrescentado a esse grupo (Mello, 1995).

\subsubsection{Magmatismo Mesozóico-Cenozóico}

No âmbito da Folha Itararé (1:250.000) tem sido reconhecido expressivo magmatismo pós-paleozóico, representado por feixes de diques básicos, além de diversas intrusões alcalinas cretáceas.

O magmatismo fissural básico apresenta-se na forma de enxames de diques de orientação preferencial NW, verticais, concentrados em dois feixes, respectivamente nas porções leste e sudoeste da área em questão correspondentes ao Arco de Ponta Grossa e ao Alinhamento de Guapiara.

É conhecida também uma série de complexos gábricos, referidos na literatura como Gabro José Fernandes, Complexo Bairro da Cruz e Complexo Gabróide de Barra do Estrela. As rochas básicas intrusivas do Complexo Bairro da Cruz e do Gabro José Fernandes forneceram idades radiométricas de $230 \pm 17$ e $190 \pm 7 \mathrm{Ma}$, respectivamente 
(Teixeira, 1982), anteriores ao magmatismo básico extrusivo da Bacia do Paraná, mas provavelmente relacionadas ao mesmo evento diastrófico.

Os diversos complexos alcalinos da Folha Itararé têm sido relacionados às estruturas do Arco de Ponta Grossa e à abertura do Atlântico Sul. 


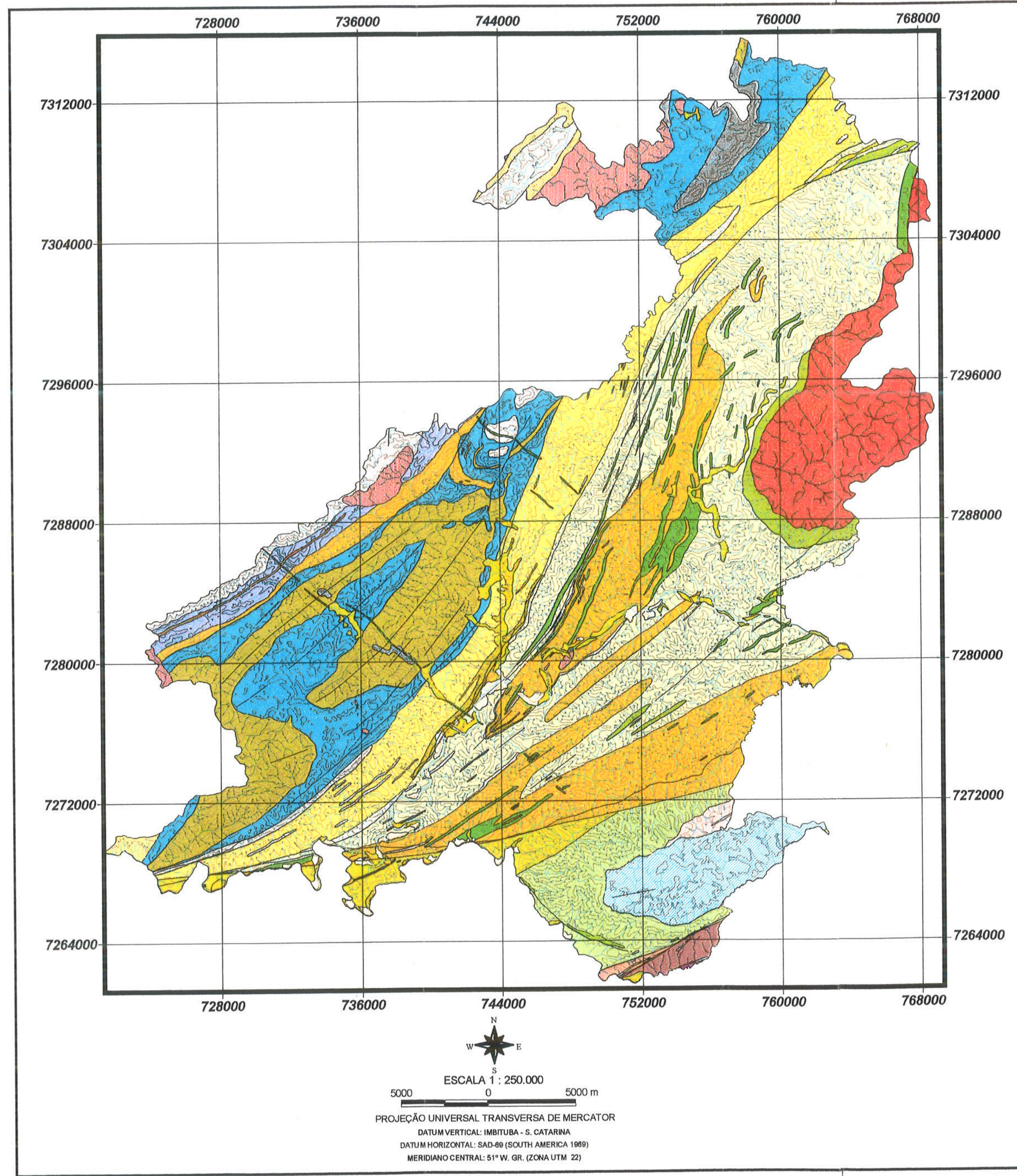

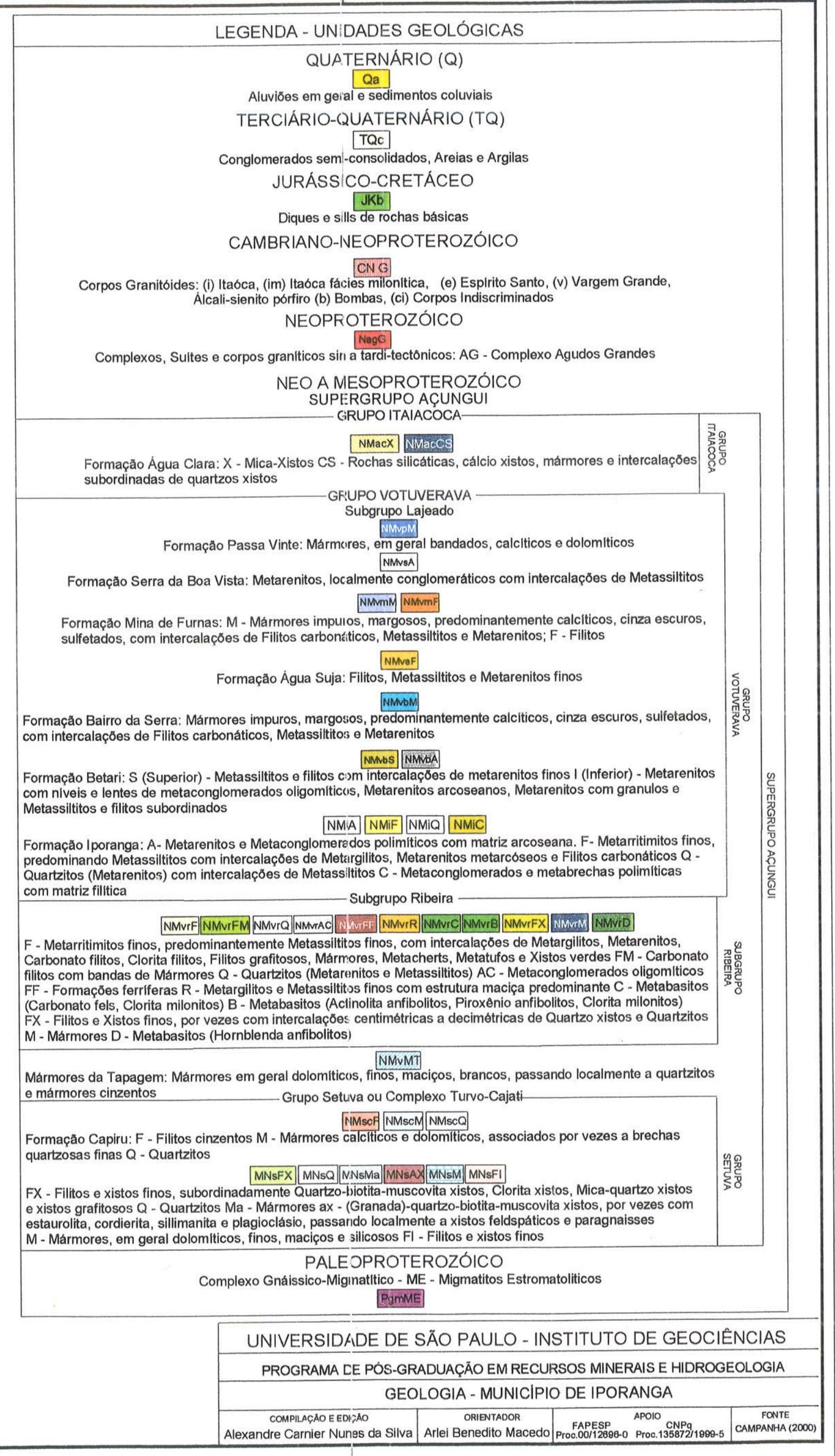




\subsection{Geomorfologia}

Os sistemas de relevo foram compilados do Macrozoneamento do Vale do Ribeira (SMA, 1996), sendo apresentados na Figura 5.2. As unidades mapeadas com base em fotografias aéreas e imagens de satélite inserem-se, quase em sua totalidade, no contexto da Província Costeira e em porções do Planalto Atlântico.

A Tabela 5.1 apresenta as características morfométricas das unidades mapeadas.

\subsubsection{Planalto Atlântico}

O Planalto Atlântico é uma unidade fisiográfica que ocupa posição superior nos interflúvios da bacia hidrográfica do rio Ribeira, entre as altitudes de 600 e 1000 metros, onde podem ser reconhecidas as áreas relativas aos Planaltos de Ibiúna, Paulistano, Guapiara e do Alto Turvo. Neste contexto os tipos de relevo mais ocorrentes, associados às litoestruturas que os sustentam, são:

- morros e morrotes graníticos do Planalto de Ibiúna;

- morros e morrotes sustentados por granitos e migmatitos do Planalto Paulistano;

- colinas, morrotes e cristas sustentados por granitos e migmatitos, ou xistos, além de relevos cársticos na presença de lentes de calcário no Planalto do Alto Turvo;

- morros e morrotes graníticos; colinas, morrotes e morros paralelos suportados por filitos; morrotes, morros paralelos e cristas suportadas por lentes de quartzito, associações de quartzitos e filitos; e morros cársticos associados ao calcário, e a intercalações de filitos e quartzitos do Planalto de Guapiara.

\subsubsection{Província Costeira}

A Provincia Costeira caracteriza-se por apresentar diferentes situações topográficas definidas por relevos com histórias evolutivas e condições morfodinâmicas distintas, conformando três zonas geomorfológicas: os Planaltos interiores ou Remanescentes de Planalto: a Serrania Costeira; e a Morraria Costeira.

\subsubsection{Remanescentes de Planalto}

Os Remanescentes de Planalto caracterizam-se por relevos de baixa a média amplitude, encontrados isolados nos cimos das serras ou próximos ao Planalto Atlântico, porém desnivelados (relevo de morros e morrotes sustentados predominantemente por rochas graníticas, e secundariamente por migmatitos do 
Complexo Costeiro, além dos morrotes e morros cársticos sustentados por mármores e dolomitos do Grupo Açungui).

\subsubsection{Serrania Costeira}

A Serrania Costeira caracteriza-se pelos relevos mais movimentados e enérgicos de todo o Vale do Ribeira. Os interflúvios principais têm seus topos nivelados com a superfície de cimeira e caem em direção ao rio Ribeira. Os vales são profundos encaixados e de grande amplitude, com estreita relação entre as rochas do embasamento e os tipos de relevo observados, que são: morros e montanhas sustentadas por rochas graníticas; montanhas, por filitos e calcários; cristas e morros paralelos sustentados por quartzitos e filitos com intercalações de quartzitos; morrotes e morros cársticos, por calcário; morros e morros paralelos sustentados por migmatitos do Grupo Açungui. Os diferentes tipos de escarpas e os morros pedimentares associam-se a diferentes tipos de rocha, já que sua morfologia é definida por sua gênese.

\subsubsection{Morraria Costeira}

Essa unidade domina a região central do Vale e do Baixo Ribeira, no sopé dos relevos montanhosos da Serrania Costeira. Os relevos aí ocorrentes são típicos de processos de pedimentação e intensa sedimentação fluvial, condicionados essencialmente pela morfogênese cenozóica, conformando morros e morrotes pedimentares, morros residuais, morrotes, colinas, rampas e morrotes em meia-laranja, além dos terraços antigos e intermediários, cones de dejeção e planicies fluviais.

A ocorrência de rochas calcárias na região do Alto Ribeira, localmente Planalto do Lageado na margem esquerda do rio Ribeira, região de Iporanga, e Planalto da Tapagem na margem direita, região de Eldorado, está relacionada à Província Espeleológica do Ribeira, a maior da região sul e sudeste do Brasil. Nessa Província são conhecidas e cadastradas mais de 310 cavidades naturais. 
Tabela 5.1 - Descrição das características das unidades representadas no mapa geomorfológico compilado (SMA, 1996).

\begin{tabular}{|c|c|c|c|}
\hline $\begin{array}{l}\text { TIPO DE } \\
\text { RELEVO }\end{array}$ & MORFOGRAFIA & SUBSTRATO ROCHOSO & DINÂMICA SUPERFICIAL \\
\hline $\begin{array}{c}\text { Morrotes pequenos } \\
\text { (MTpq) } \\
\text { decl.: } 10 \text { a } 40 \% \\
\text { Ampl.: } 20 \text { a } 80 \mathrm{~m} \\
\end{array}$ & $\begin{array}{c}\text { Formas subniveladas com área inferior a } 0,5 \mathrm{~km}^{2} \text {. Topos estreitos convexos. Perfil } \\
\text { de vertente continuo, retilineo a convexo. Vales erosivos e erosivos cumulativos. } \\
\text { Planicies fiuviais estreitas. Canais em rocha e aluviais. Densidade de drenagem } \\
\text { média a alta. }\end{array}$ & Filitos do Grupo Açungui & Rastejo é localizado. \\
\hline $\begin{array}{l}\text { Morrotes } \\
\text { (MT) } \\
\text { decl: } 10 \text { a } 40 \% \\
\text { Ampl.: } 40 \text { a } 100 \mathrm{~m}\end{array}$ & $\begin{array}{c}\text { Formas subniveladas. Topos estreitos corvexos. Perfil de vertente continuo } \\
\text { retillneo a convexo. Vales erosivos acumulativos nas cabeceiras e acumulativos } \\
\text { abertos nas drenagens maiores com planicies fluviais pequenas. Canais em rocha } \\
\text { e aluviais. Densidade de drenagem média. }\end{array}$ & $\begin{array}{c}\text { Quartzitos e Migmatitos do Grupo } \\
\text { Açungui } \\
\text { (Fillitos do Grupo Açungui) }\end{array}$ & $\begin{array}{l}\text { Escoamento laminar e concentrado sâo localizados e } \\
\text { ocasionais. }\end{array}$ \\
\hline $\begin{array}{l}\text { Morrotes e morros } \\
\text { (MTm) } \\
\text { decl:: } 20 \text { a } 60 \% \\
\text { Ampl.: } 60 \text { a } 100 \mathrm{~m}\end{array}$ & $\begin{array}{l}\text { Formas subniveladas angulosas. Topos estreitos convexos e agudos. Perfil de } \\
\text { vertente continuo retilineo. Vales erosivos em } V \text { encaixados. Canais em rocha. } \\
\text { Densidade de drenagem alta. }\end{array}$ & Filitos do Grupo Açungui & $\begin{array}{l}\text { Escoamento laminar, concentrado, ravinamento e entalhe } \\
\text { fluvial, generalizado e freqüente. } \\
\text { Rastejo localizado e freqüente. }\end{array}$ \\
\hline $\begin{array}{l}\text { Cristas e morros } \\
\text { paralelos } \\
\text { (CRmp) } \\
\text { decl.: } 30 \text { a } 50 \% \\
\text { Ampl: } 130 \text { a } 300 \mathrm{~m} \\
\end{array}$ & $\begin{array}{l}\text { Formas desniveladas. Topos estreitos agudos e convexos. Perfil de vertente } \\
\text { descontinuo segmentos retilineos e convexos. Vales erosivos em } V \text { pouco } \\
\text { encaixados. Canais em rocha e blocos. Densidade de drenagem média. }\end{array}$ & $\begin{array}{c}\text { Quartzitos } \\
\text { Filitos e Xistos do Grupo Açungui }\end{array}$ & $\begin{array}{l}\text { Escoamento concentrado e ravinamento localizados. } \\
\text { Rastejo, escorregamento e quedas de bloco sāo } \\
\text { generalizados \& freqüentes. }\end{array}$ \\
\hline $\begin{array}{l}\text { Morrotes e morros } \\
\text { cársticos } \\
\text { (MTmc) } \\
\text { decl:: 10 a } 50 \% \\
\text { Ampl: } 60 \text { a } 180 \mathrm{~m} \\
\end{array}$ & $\begin{array}{l}\text { Formas desniveladas e cônicas. Topos estreitos convexos e picos. Perfil de } \\
\text { vertente continuos segmentos convexos e retilineos. Vales abertos com dolinas, } \\
\text { sumidouros e cavernas. Canais em rocha. Densidade de drenagem baixa. }\end{array}$ & Calcários do Grupo Açungui & $\begin{array}{c}\text { Processos quimicos de dissolução e carbonatação sāo } \\
\text { generalizados e continuos. } \\
\text { Rastejo, pequenos escorregamentos e abatimentos de solo } \\
\text { são generalizados e frequentes. }\end{array}$ \\
\hline $\begin{array}{c}\text { Morros maciços } \\
(\text { Mm) } \\
\text { decl: } 20 \text { a } 45 \% \\
\text { Ampl.: } 100 \text { a } 220 \mathrm{~m}\end{array}$ & $\begin{array}{l}\text { Formas desniveladas. Topos estreitos agudos associados a picos proeminentes. } \\
\text { Perfil de vertente descontinuo segmentos retilineos. Vales erosivos em } V \\
\text { encaixado nas cabeceiras e erosinos acumulativos abertos. Canais em rocha e } \\
\text { aluviais. Densidade de drenagem alta. }\end{array}$ & Filitos do Grupo Açungui & $\begin{array}{l}\text { Escoamento concentrado, ravinamento e rastejo são } \\
\text { generalizados e frequientes. } \\
\text { Escoamento são localizados e ocasionais. } \\
\text { Quedas de blocos localizados as vertentes rochosas. }\end{array}$ \\
\hline 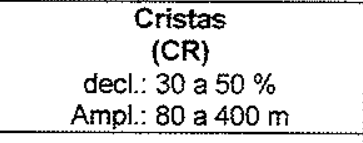 & $\begin{array}{l}\text { Formas alongadas subriveladas. Topos estreitos agudos e rochosos. Perfil de } \\
\text { vertente contínuo, segmentos retillneos. Vales erosivos e pouco encaixado. } \\
\text { Canais em rocha. densidade de drenagem atta. }\end{array}$ & $\begin{array}{c}\text { Quartzitos } \\
\text { Filitos e Xistos do Grupo Açungui }\end{array}$ & $\begin{array}{l}\text { Escoamento concentrado e ravinamentos localizados. } \\
\text { Rastejo, escorregamento e quedas de bloco såo } \\
\text { generalizados e freqüentes. }\end{array}$ \\
\hline $\begin{array}{l}\text { Escarpas } \\
\text { (E) } \\
\text { decl.: maior } 40 \% \\
\text { Ampl:: superior a } 100 \mathrm{~m}\end{array}$ & $\begin{array}{c}\text { Forma alongada, assimétrica e subnivelada. Na cimeira tem ruptura de declive } \\
\text { nitida. Perfil de vertente continuo retilineo ou descontinuo devido a rupturas de } \\
\text { declive negativa que na porçấo interior delimita segmento convexo com corpo de } \\
\text { talus elou rampa pedimentar. Vales erosivos em } V \text { aberto pouco encaixados. } \\
\text { Baixa densidade de drenagem. }\end{array}$ & \multirow{4}{*}{$\begin{array}{l}\text { Variável, podendo ocorrer em } \\
\text { qualquer tipo de rocha. } \\
\text { A moricgrafia é geraimente } \\
\text { condicionada pela } \\
\text { compartimentação estrutural do } \\
\text { maciço. }\end{array}$} & $\begin{array}{l}\text { Rastejo, escorregamentos planares e quedas de blocos } \\
\text { são generalizados e freqüentes. } \\
\text { Entaihe fluvial localizado e incipiente. }\end{array}$ \\
\hline $\begin{array}{l}\text { Escarpas degradadas por } \\
\text { vales subparalelos } \\
\text { (Ev) } \\
\text { decl.: maior } 40 \% \\
\text { Ampl.: superio: a } 200 \mathrm{~m}\end{array}$ & $\begin{array}{c}\text { Formas dissecadas por drenagem de padrāo paralelo e sub-paralelo. Os } \\
\text { interfúvios são desnivelados. Topos estreitos agudos passando a convexos nas } \\
\text { porçöes mais baixas. Pernil de vertente continto longo, segmentos retilineos e ou } \\
\text { convexos. Vales erosivos em } \vee \text { profundos. Canais em rocha e blocos. Densidade } \\
\text { de drenagem média. }\end{array}$ & & $\begin{array}{l}\text { Rastejo e escorregamentos sâo generailzados e } \\
\text { frequuentes. } \\
\text { Queda de bloco freqưente nas verientes com caimento } \\
\text { contrário ao merguho da foliação. } \\
\text { Entalhe fluvial significativo nas vertentes com caimento } \\
\text { paralelo ao merguho da foliação e ao longo do vale } \\
\text { principal. }\end{array}$ \\
\hline $\begin{array}{l}\text { Escarpas degradadas por } \\
\text { anfiteatros } \\
\text { (Ea) } \\
\text { decl.: } 30 \text { a } 50 \% \\
\text { Ampl: } 180 \text { a } 500 \mathrm{~m} \\
\end{array}$ & $\begin{array}{c}\text { Formas dissecadas por drenagem de padräo dentritico e subdentrifico. Os } \\
\text { interflúvios principais são desnivelados e dispostos em semi circulo. Topos } \\
\text { estreitos agudos passando a convexos nas porçōes mais baixas. Perfil de vertente } \\
\text { descontinuo segmentos retilineos e convexos. Vales erosivos e erosivos } \\
\text { acumulativos en V aberto. Associam-se planícies alveolares e cones de dejeçăo. } \\
\text { Densidade de drenagem alta. }\end{array}$ & & $\begin{array}{l}\begin{array}{l}\text { Rastejo e escorregamentos säo generalizados e } \\
\text { freqüentes. }\end{array} \\
\text { Entalhe fluvial é generalizado e intenso. } \\
\text { A deposiçăo é localizada e seletiva a montante de soleiras. }\end{array}$ \\
\hline $\begin{array}{l}\text { Escarpas com } \\
\text { degradaçăo complexa } \\
\text { (Ec) } \\
\text { decl: maior } 40 \% \\
\text { Ampl.: superior } a 200 \mathrm{~m}\end{array}$ & $\begin{array}{c}\text { Formas dissecadas por diferentes padróes de drenagem. Os interfluvios são } \\
\text { desnivelados e dispostos de modo irregular. Topos estreitos agudos e convexos } \\
\text { nas porçoes mais baixas. Perfil de vertente descontinuo e/on continuo, segmentos } \\
\text { retiliness elou convexos. Vales erosivos e erosivos acumulativos en V. Podem } \\
\text { apresentar planicies alveolares e cones de dejeçäo. Densidade de drenagem } \\
\text { média a alta. }\end{array}$ & & $\begin{array}{l}\text { Associam-se os diferentes processos observados nos } \\
\text { outros tipos de escarpas degradadas que são variáveis em } \\
\text { conseqüência da morfologia. }\end{array}$ \\
\hline $\begin{array}{l}\text { Montanhas } \\
\text { (MH) } \\
\text { decl:: } 30 \% \text { a } 50 \% \\
\text { Ampl.: } 180 \text { a } 500 \mathrm{~m}\end{array}$ & $\begin{array}{c}\text { Formas macicas desniveladas. Topos estreitos agudos e rochosos e picos } \\
\text { isolados. Perfil de vertente descontinuo, segmentos longos retilineos, e } \\
\text { subordinadamente convexos. Vales erosivos em } V \text { abertos profundos. Canais em } \\
\text { rocha e blocos. Densidade de drenagem media a alta. Canais de } 1^{2} \text { ordem pouco } \\
\text { encaixados. }\end{array}$ & \multirow{3}{*}{$\begin{array}{l}\text { Migmatitos, xistos e filitos do } \\
\text { Grupo Açungui }\end{array}$} & $\begin{array}{l}\text { Entalhe fluvial generalizado e intenso. } \\
\text { Processos quimicos de dissoluçăo, carbonataçăa e } \\
\text { abatimentos de solo localizados e continuos. } \\
\text { Rastejo, escorregamentos e quedas de blocos } \\
\text { generalizados e frequeentes. }\end{array}$ \\
\hline $\begin{array}{l}\text { Montanhas e morros } \\
\text { (MHm) } \\
\text { deci.: } 25 \% \text { a } 50 \% \\
\text { Ampl.: } 200 \text { a } 400 \mathrm{~m} \\
\end{array}$ & $\begin{array}{l}\text { Formas dissecadas, angulosas e desniveladas. Topos estreitos agudos. Perfil de } \\
\text { vertente descontinuo, segmentos curtos e retilineos. Vales erosivos em } V \\
\text { profundamente encaixados. Canais em rocha e blocos. Densidade de drenagem } \\
\text { alta formando densa rede de pequenos vales de } 1^{\mathrm{a}} \text { ordem. }\end{array}$ & & $\begin{array}{l}\text { Escoamento superficial, concentrado, ravinamento e rastejo } \\
\text { säo generalizados e freqüentes. }\end{array}$ \\
\hline $\begin{array}{l}\text { Morros graniticos } \\
\qquad(\mathrm{Mg}) \\
\text { decl.: } 15 \% \text { a } 40 \% \\
\text { Ampl:: } 90 \text { a } 300 \mathrm{~m}\end{array}$ & $\begin{array}{c}\text { Formas desniveladas muto dissecadas. Topos estreitos agudos. Perfil de vertente } \\
\text { continuo, segmentos longos retilineos com campos de matacoes e afloramentos } \\
\text { rochosos. Vales erosivos em } \vee \text { fechado. Canais em rocha. Densidade de } \\
\text { drenagem muito aita. }\end{array}$ & & $\begin{array}{l}\begin{array}{l}\text { Escorregamentos e quedas de blocos localizados e } \\
\text { freqüentes. }\end{array} \\
\text { Entalhe fluvial generalizado e intenso. }\end{array}$ \\
\hline $\begin{array}{l}\text { Morrotes pedimentares } \\
\text { (MTpd) } \\
\text { deci.: } 20 \% \text { a } 40 \% \\
\text { Ampl.: } 60 \text { a } 100 \mathrm{~m} \\
\end{array}$ & $\begin{array}{c}\text { Formas subriveladas desenvolvidas a partir de ruptura de declive negativa no } \\
\text { sopé dos relevos mais elevados. Topos estreitos agudos e convexos. Perfil de } \\
\text { vertente continuo segmentos curtos retilineos. Vales erosivos e erosivos } \\
\text { acumulativos. Planícies fluviais estreitas. Canais em rocha e aluviais. Densidade } \\
\text { de drenagem média. }\end{array}$ & $\begin{array}{l}\text { Migmatitos do Complexo Costeiro } \\
\text { (Xistos e Migmatitos do Grupo } \\
\text { Açungui, Granitos e quarzitos do } \\
\text { Grupo Açungui) }\end{array}$ & $\begin{array}{l}\text { Deposição de finos por decantação durante as cheias é } \\
\text { generalizada. } \\
\text { Escoamento Laminar, concentrado, rastejo e } \\
\text { escorregamentos são localizados e ocasionais. } \\
\text { Erosão fluvial restrita a ação lateral do canal. }\end{array}$ \\
\hline $\begin{array}{l}\text { Planicie Fluvial (Pt) } \\
\text { elevadas de } 2 \text { a } 8 \mathrm{~m} \text { acima } \\
\text { dos rios } \\
\text { decl. menor } 2 \% \\
\end{array}$ & $\begin{array}{c}\text { Compreende a planicie de inundaçăo e baixos terraços. São terrenos planos, que } \\
\text { podem ter bordas abruptas devido a erosão lateral do canal. Associam-se áreas } \\
\text { alagadas e pantanosas. }\end{array}$ & $\begin{array}{l}\text { Inclui silke, areias, argilas e } \\
\text { camadas de cascalhos em } \\
\text { arranjos diversos. }\end{array}$ & $\begin{array}{l}\text { Alternância de processos erosivos e deposicionais: entaihe } \\
\text { lateral e vertical dos canais. Deposiç̧̃o em barras e por } \\
\text { decantaçăo durante as cheias. }\end{array}$ \\
\hline $\begin{array}{l}\text { Terraços intermediários } \\
\text { (T2) } \\
\text { elevadas de } 25 \text { a } 30 \mathrm{~m} \\
\text { acima dos rios } \\
\text { decl. menor } 5 \% \\
\end{array}$ & $\begin{array}{l}\text { Formas deposicionais de superficie subhorizontal com bordas abruptas. } \\
\text { Densidade de drenagem baixissima. }\end{array}$ & $\begin{array}{l}\text { Cascalhos oligomíticos areias } \\
\text { arcoseanas e lamitos. Espessura } \\
\text { de até } 10 \mathrm{~m} \text {. }\end{array}$ & \multirow[b]{2}{*}{$\begin{array}{l}\text { Erosão laminar concentrada e entahe fluvial localizado e } \\
\text { incipiente. }\end{array}$} \\
\hline $\begin{array}{l}\text { Terraços antigos (T3) } \\
\text { elevadas de } 50 \text { a } 60 \mathrm{~m} \\
\text { acima dos rios } \\
\text { decl. menor } 5 \%\end{array}$ & $\begin{array}{c}\text { Englobam terracos acumulativos e erosivos. Formas subniveladas e dissecadas } \\
\text { por vezes gerando pequenas colinas. Vales erosivos aberios. Densidade de } \\
\text { drenagem baixa. }\end{array}$ & $\begin{array}{l}\text { Cascalhos oligomiticos areias } \\
\text { arcoseanas e laminares. } \\
\text { Espessura des até } 8 \mathrm{~m} \text {. }\end{array}$ & \\
\hline $\begin{array}{l}\text { Cones de dejeção e } \\
\text { corpos de tálus } \\
\text { (CD) } \\
\text { decl.: } 10 \text { a } 33 \%\end{array}$ & $\begin{array}{l}\text { Rampas subhorizontais elou convexas associadas ao fundo de vales e ao sopé } \\
\text { das vertentes elevadas. }\end{array}$ & $\begin{array}{l}\text { Matacöes, blocos e cascalhos } \\
\text { imersos em matriz areno-argilosa } \\
\text { arcoseana. }\end{array}$ & $\begin{array}{l}\text { Entalhe lateral e vertical dos canais é frequente. } \\
\text { Deposição de detritos localizada e ocasional. } \\
\text { Rastejo localizado e frequente. }\end{array}$ \\
\hline $\begin{array}{c}\text { Rampas }(R) \\
\text { decl: } 1,5 \% \text { a } 5,0 \% \\
\text { Ampl: } 5 \text { a } 40 \mathrm{~m} \\
\end{array}$ & $\begin{array}{l}\text { Formas subniveladas. Terrenos planos e levemente ondulados. Vales } \\
\text { acumulativos abertos pouco marcados no terreno. Planicies fluviais amplas. } \\
\text { Canais aluviais meandrantes. Densidade de drenagem baixa. }\end{array}$ & $\begin{array}{l}\text { Cascalhos, brechas, areias, siltes } \\
\text { e argilas da Formaçăo Pariquera- } \\
\text { Acú. }\end{array}$ & $\begin{array}{l}\text { Erosão laminar e concentrada é localizada e ocaional. } \\
\text { Deposição fluvial localizada. }\end{array}$ \\
\hline $\begin{array}{c}\text { Morros }(\mathrm{M}) \\
\text { decl.: } 20 \text { a } 40 \% \\
\text { Ampl.: } 80 \text { a } 120 \mathrm{~m} \\
\end{array}$ & $\begin{array}{l}\text { Formas desniveladas. Topos estreitos convexos. Perfil de vertente continuo } \\
\text { retilineo a convexo. Vales erosivos em } \vee \text { nas cabeceiras e erosivos acumulativos } \\
\text { nas drenagens mais organizada. Planicies fluviais estreitas interrompidas por } \\
\text { soleiras. Canais em rochae aluviais. Densidade de drenagem média a alta. }\end{array}$ & $\begin{array}{l}\text { Migmatitos do Grupo Açungui } \\
\text { Granitos }\end{array}$ & Quedas de blocos localizados as vertentes rochosas. \\
\hline
\end{tabular}




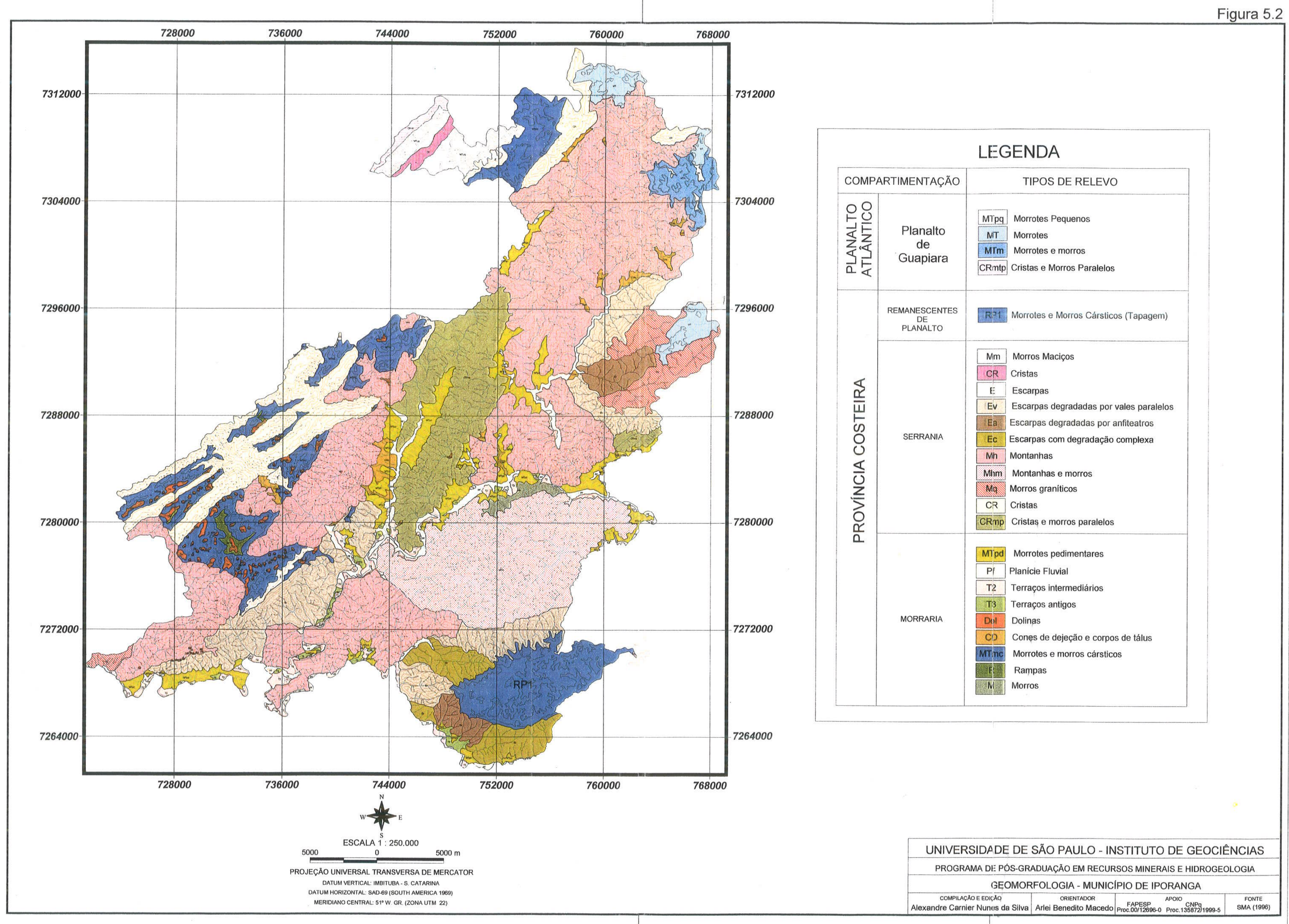




\subsection{Pedologia}

Os principais tipos de solos mapeados por Lepsch et al. (1990), estão descritos abaixo, e são apresentados na Figura 5.3.

\subsubsection{Latossolo vermelho-amarelo álico (LVa)}

Apresentam coloração vermelho-amarelada, com baixos teores de óxidos de ferro (menos de 8\%). A maior parte desses latossolos são intermediários para cambissolos, sendo por isso classificados como Latossolo Vermelho Amarelo Câmbico, pouco profundo. Ocorrem, principalmente, em antigas superfícies dissecadas de altos planaltos, em relevo ondulado ou forte ondulado.

O mapa pedológico apresenta as seguintes unidades:

LVa3 - Associação Latossolo Vermelho-Amarelo Álico, ambos A moderado textura argilosa fase floresta perenifólia tropical transição para subtropical relevo forte ondulado.

LVa4 - Associação Latossolo Vermelho-Amarelo Álico + Latossolo Vermelho Amarelo Álico pouco profundo + Cambissolo Álico Tb substrato metassedimentos sílticoargilosos, todos $\mathrm{A}$ moderado textura muito argilosa fase floresta tropical perenifólia transição para subtropical perúmida relevo forte ondulado.

\subsubsection{Podzólico Vermelho-Amarelo (PVd)}

São solos com profundidade variável, encontrados normalmente em áreas de relevo ondulado e forte ondulado ou montanhoso. Ao contrário dos latossolos, apresentam na maior parte dos casos, acentuada diferenciação de horizontes, destacando-se o horizonte $B$ textural enriquecido de argila iluviada do horizonte A. Diferenciam-se por dois atributos: os distróficos, devido à saturação de bases inferior a $50 \%$ e os eutróficos, por apresentarem saturação por bases iguais ou superior a $50 \%$.

Os distróficos correspondem aos seguintes tipos:

PVd1 - Podzólico Vermelho-Amarelo Distrófico Tb A moderado textura média/argilosa fase floresta tropical perenifólia relevo suave ondulado a plano.

PVd2 - Associação Podzólico Vermelho-Amarelo Distrófico Tb textura argilosa/muito argilosa + Cambissolo Distrófico Tb textura argilosa substrato granulito ou migmatito, todos A moderado fase rochosa a pedregosa floresta tropical perenifólia relevo montanhoso. 
PVa6 - Associação Podzólico Vermelho-Amarelo Álico (epidistrófico) Tb A moderado (abrupto e não abrupto) textura média cascalhenta/argilosa com cascalho + Cambissolo Distrófico Tb A chernozêmico textura média com cascalho substrato granito, ambos fase floresta perenifólia tropical transição para subtropical relevo montanhoso.

\subsubsection{Brunizém (BV)}

São solos com profundidade variável, encontrados normalmente, em áreas de relevo escarpado. Apresentam o horizonte $B$ textural enriquecido de argila iluviada do horizonte A. A associação descrita é:

BV2 - Associação complexa BRUNIZÉM textura argilosa + RENDZINA textura média ambos fase floresta tropical subperenifólia relevo escarpado.

\subsubsection{Cambissolos (Ca)}

Constituem os solos minerais com horizonte $B$ câmbico ou incipiente, não hidromórficos, com pouca diferenciação de textura entre o horizonte A para B. Muitas vezes apresentam caracteristicas similares aos solos com horizonte B latossólico, diferenciando-se por serem menos evoluídos, menos profundos e por apresentarem minerais primários de fácil intemperização; ou pela atividade de argila, que apesar de variar de alta a baixa é normalmente superior à dos Latossolos, ou ainda pelos teores de silte mais elevados.

Os cambissolos ocorrem nas regiões serranas de relevo montanhoso e escarpado, cobertos com a vegetação de Floresta Ombrófila. Estes solos, de um modo geral, não são utilizados agricolamente, apresentando como fatores limitantes, o relevo acentuado e o excesso de alumínio. São encontrados os seguintes tipos:

Ce2 - Associação complexa Cambissolo Eutrófico Ta A moderado textura argilosa sustrato calcário + Brunizém Avermelhado textura argilosa + Solo Litólico Eutrófico Ta A moderado textura média ou argilosa sustrato calcário, todos fase rochosa floresta tropical perenifólia ou perúmida relevo montanhoso ou escarpado.

Ca2 - Associação Cambissolo Álico Tb textura argilosa substrato filito-xisto + Podzólico Vermelho-Amarelo Álico Tb textura média/argilosa ou argilosa/muito argilosa, ambos $\mathrm{A}$ moderado fase relevo forte ondulado ou montanhoso.

Ca3 - Associação Cambissolo Álico Tb A moderado textura muito argilosa fase floresta tropical perenifólia + Solos Litólicos Álicos Tb moderado fase campo tropical arbustivo, ambos substrato metassedimentos síltico-argilosos relevo montanhoso ou escarpado. 
Ca4 - Associação Cambissolo Álico Tb + Cambissolo Latossólico Álico, ambos A moderado textura argilosa ou argilosa com cascalho substrato granito fase floresta tropical perenifólia ou perúmida relevo montanhoso.

\subsubsection{Glei (Gd)}

Os solos deste tipo apresentam-se descritos como:

Gd - Associação complexa de Solo Glei Pouco Húmico e Húmico Distróficos ou Eutróficos $\mathrm{Tb}$ textura argilosa fase campo tropical higrófilo de várzea e Cambissolo Distrófico e Eutrófico Tb A moderado, textura argilosa/média ou argilosa substrato sedimentos aluviais fase floresta tropical higrófila de várzea, ambos relevo plano.

\subsubsection{Solos litólicos (Ra)}

Os solos deste tipo apresentam-se descritos como:

Ra1 - Associação Solos Litólicos Álicos Tb textura média + Afloramentos Rochosos ambos substrato quartzito fase campo tropical subperenifólio relevo escarpado.

Ra3 - Associação Solos Litólicos Álicos + Cambissolos Álicos, ambos Tob A moderado sustrato metassedimentos síltico-argilosos fase campo e floresta tropical perenifólia relevo escarpado. 


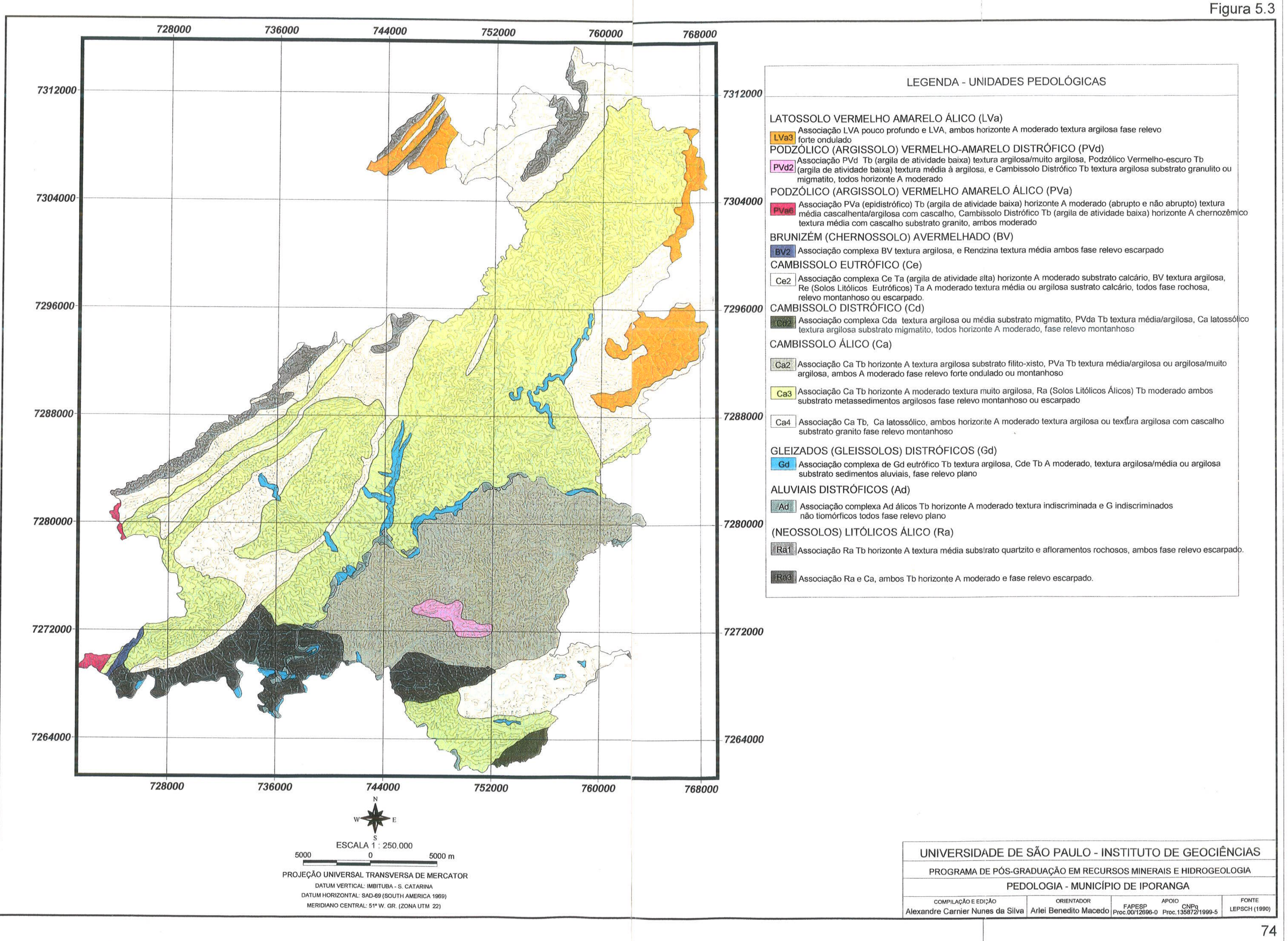




\subsection{Aptidão agrícola das terras}

Ramalho Filho et al. (1978) propôs a classificação da aptidão agricola das terras levando em consideração a qualidade das terras em relação a um conjunto de lavouras "climaticamente adaptadas" à região em pauta. A aptidão agrícola das terras do município de Iporanga é apresentada na figura 5.4.

Nesse sistema, considerações sobre a qualidade das terras, julgadas a partir de suas características, basicamente definem as classes de aptidão agrícola: boa, regular ou marginal e inapta. As terras com aptidão boa são as que têm solos com características próximas do "ideal".

O solo ideal é imaginado como aquele que não apresenta problemas de fertilidade, deficiência de água ou oxigênio, não é suscetivel à erosão nem oferece impedimentos à mecanização, apresentando potencialidade para obtenção de boa colheita. De acordo com a variação em relação às características do solo ideal, relacionados aos fatores limitantes, o conjunto de terras pode ser enquadrado em uma das quatro classes citadas.

Para a definição das classes de aptidão, considera-se que muitas qualidades da terra podem variar não somente em função das características da sua unidade de mapeamento, como também, pelo tipo de utilização prevista. Diferentes utilizações da terra podem ser conseqüência tanto da variação da espécie, ou mesmo variedade, da planta cultivada, quando do nível de manejo empregado pelo agricultor.

Lepsch et al. (1990) exemplifica que a suscetibilidade à erosão de uma mesma gleba de terra pode diferir quando ela é cultivada com milho, cana-de-açúcar ou cacau e, ainda, para um único tipo de cultivo, se as glebas são cultivadas com plantio direto mecanizado ou a partir de plantios motomecanizados convencionais. Além disso, uma terra naturalmente muito fértil, mas com afloramentos rochosos à superficie e declives não uniformes, pode ser de boa qualidade para pequenos cultivos manuais, em manejo baixo, mas será imprópria para grandes cultivos, altamente mecanizados.

Na classificação de Ramalho Filho et al. (1978) a variação que existe em virtude da unidade de mapeamento de solo e o seu tipo de utilização prevista é contornado, pois este considera três combinações do contexto social e econômico, assim definidas:

\subsubsection{Nível de manejo $A$}

Pressupõe práticas que refletem baixo nivel tecnológico. É caracterizado por pouca aplicação de capital para melhorar as condições naturais de terra e práticas 
agrícolas que dependem primordialmente do trabalho manual, ou de tração animal e implementos agrícolas simples.

\subsubsection{Nível de manejo B}

Pressupõe médio nível tecnológico, caracterizado por modesta aplicação de capital e de resultados de pesquisas para manejo, melhoramento e conservação das condições naturais das terras, e práticas agrícolas baseadas principalmente na tração animal.

\subsubsection{Nível de manejo C}

Pressupõe alto nivel tecnológico, caracterizado pela aplicação intensiva de capital e de resultados de pesquisa para manejo, melhoramento e conservação das condições das terras. A mecanização está presente em todas as fases das operações agrícolas.

\subsubsection{Classes de aptidão agrícola}

Neste sistema as classes de aptidão agrícola são definidas conforme apresentado a seguir.

\subsubsection{Classe Boa}

Terras sem limitações significativas para produção sustentada de determinado tipo de utilização agrícola, nas condições do nível de manejo considerado. Podem ocorrer restrições que não reduzem a produtividade ou os benefícios de maneira expressiva nem aumentem os insumos necessários acima do aceitável.

\subsubsection{Classe Regular}

Terras que apresentam limitações moderadas para produção sustentada de determinado tipo de utilização agrícola, nas condições do manejo considerado. As limitações reduzem a produtividade ou os benefícios, elevando a necessidade de insumos, a fim de aumentar as vantagens globais a serem obtidas com o uso da terra.

\subsubsection{Classe Restrita}

Terras que apresentam limitações fortes para produção sustentada de determinado tipo de utilização agrícola, nas condições do manejo considerado. Essas 
limitações reduzem a produtividade ou os benefícios ou, então, aumentam a necessidade de insumos de tal maneira que os custos só se justificam marginalmente.

\subsubsection{Classe Inapta}

Terras apresentando condições desfavoráveis, de modo a excluir a produção sustentada do tipo de utilização agrícola considerado.

Lepsch et al. (1990) utilizaram também, para delimitação das classes de aptidão, o agrupamento pedológico, as informações de declividade e risco de inundação.

\subsubsection{Riscos de Inundação}

As várzeas do Ribeira de Iguape, em sua maioria, e de seus afluentes estão sujeitas a inundações periódicas, e quando estas são freqüentes e duradouras são um fator limitante à agricultura, principalmente lavouras anuais.

Lepsch et al. (1990) definiram as principais classes de risco de inundação como as seguintes:

\subsubsection{Inundações freqüentes e curtas}

São as que ocorrem nas várzeas menores, próximo a nascentes, com recorrência entre um e cinco anos, mas durando menos de dois dias. Muitas vezes, podem ser controladas pela limpeza e retificação dos córregos, dando uma maior velocidade às águas.

\subsubsection{Inundações muito freqüentes e curtas}

Säo as que afluem nas várzeas menores ou médias, a cerca de $1.000-3.000 \mathrm{~m}$ da nascente; ocorrem sistematicamente quase todos os anos e, em certas ocasiōes, mais de uma vez por ano, mas com duração de menos de dois dias. Normalmente os danos são maiores nas lavouras anuais, mas as perenes (como banana) podem resistir a essas inundações sem grandes danos ou perda total.

\subsubsection{Inundações muito freqüentes e de média duração}

São as que ocorrem nas várzeas maiores, principalmente no baixo curso do Ribeira e seus afluentes; elas sobrevêm sistematicamente quase todos os anos e duram de dois a trinta dias, podendo, portanto, ocasionar danos totais tanto a cultivos anuais quanto perenes. 


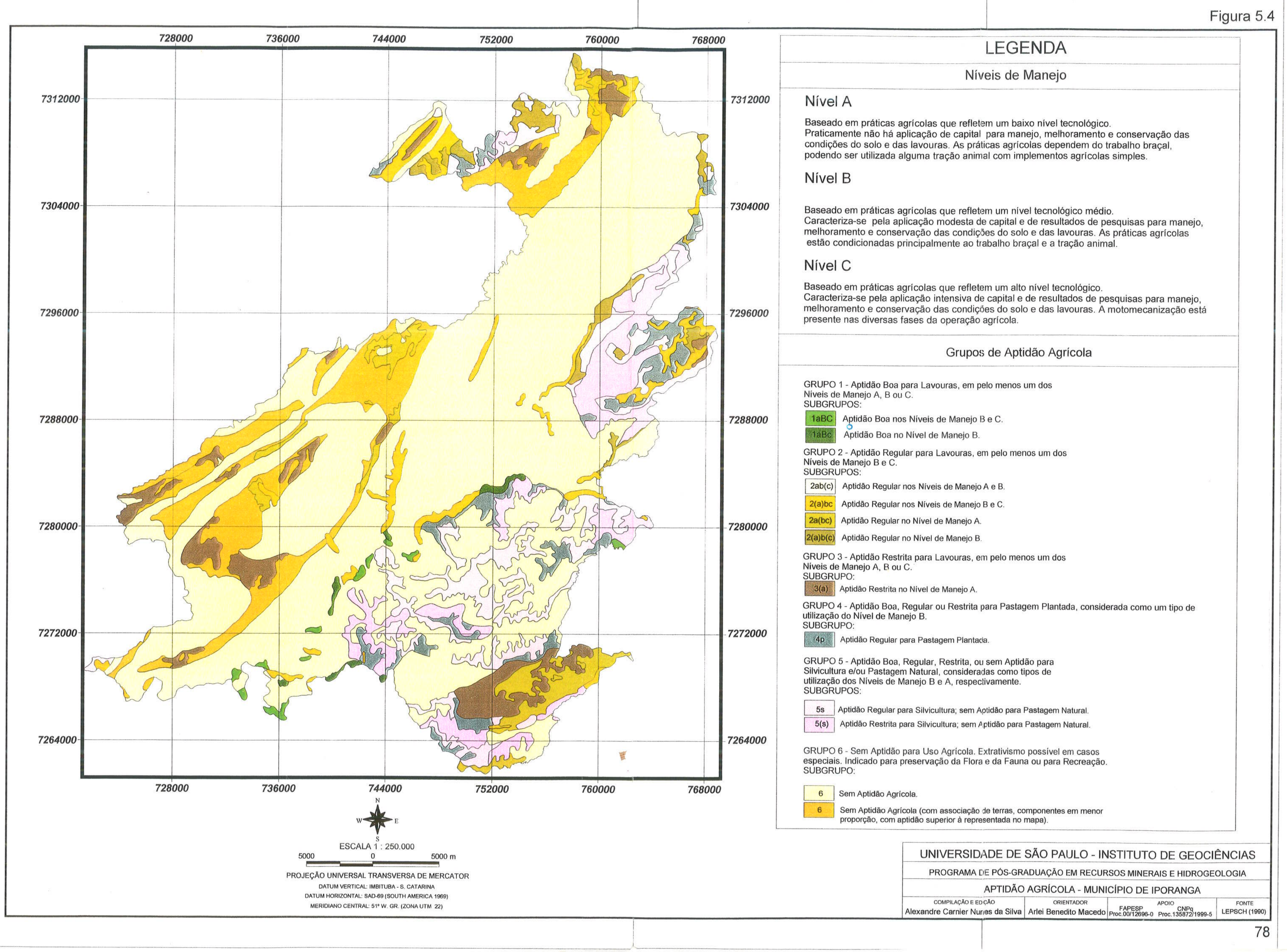




\subsection{Capacidade de uso da terra}

A capacidade de uso das terras do município de Iporanga é apresentada na Figura 5.5. O conceito de capacidade de uso da terra está ligado às atividades agrícolas que potencialmente podem ser desenvolvidas em uma área, levando em consideração o adequado uso da terra. O termo terra adquire um sentido mais amplo nessa concepção podendo ser entendido segundo a FAO (1976, apud Lepsch, 1991) como um segmento da superfície do globo terrestre definido no espaço e reconhecido em função de características e propriedades compreendidas pelos atributos da biosfera, atmosfera, solo, substrato geológico, hidrologia e resultado das atividades humanas futuras $e$ atuais até o ponto que estes atributos exerçam influência significativa no uso presente ou futuro da terra pelo homem.

Essa definição engloba portanto não apenas o conceito de solo, mas também outros atributos físicos, como relevo, vegetação, tipos e grau de erosão, disponibilidade de água e impedimentos à moto-mecanização. Sua utilização agrícola, além desses atributos, depende também de condições de inframestrutura (meios de transporte, instalações, máquinas e equipamentos) e, ainda, condições sócio-econômicas (salubridade da região, disponibilidade de mão-de-obra, mercado, preços de insumos e de produtos agropecuários).

A adaptação das terras às várias modalidades de utilização agrosilvopastoril está diretamente relacionada à sua capacidade de uso, idéia que está diretamente ligada às possibilidades e limitações que elas apresentam. Segundo Lepsch (1991) a capacidade de uso da terra é a sua adaptabilidade para fins diversos, sem que sofra perdas (depauperamento) pelos fatores de desgaste e empobrecimento. Essa concepção engloba ainda os efeitos de condições do meio físico (incluindo o clima) na aptidão da terra para ser utilizada de forma que não ocorram danos consideráveis por desgaste e empobrecimento, através de cultivos anuais, perenes, pastagem, reflorestamento ou vida silvestre.

O sistema de capacidade de uso é uma classificação técnico-interpretativa, originalmente desenvolvida nos Estados Unidos, representando um agrupamento qualitativo de tipos de solos, em termos do propósito de definir sua máxima capacidade de uso sem risco de degradação do solo, especialmente no que diz respeito à erosão acelerada.

Conforme Hudson (1971, apud Lepsch 1991), assim como outras modalidades de classificação, este tipo de classificação técnica tem o propósito particular de indicar 
os dados que levem a decidir qual a combinação de uso agrícola e medidas de controle da erosão que permitem o aproveitamento mais intensivo da terra, sem risco de depauperamento do solo. Assim o sistema se baseia nas limitações permanentes das terras e é todo voltado para as possibilidades e limitações à utilização das mesmas, idéia esta diretamente relacionada à sua intensidade de uso.

A intensidade de uso exprime a maior ou menor mobilização imposta ao solo, expondo-o a certo risco de erosão e/ou perda da produtividade. Geralmente, culturas anuais impõem alta intensidade de uso, enquanto vegetações naturais apresentam o mais baixo grau de intensidade de uso.

A determinação da capacidade de uso da terra é uma poderosa ferramenta utilizável no planejamento e uso do solo. Contudo, não fornece todos os elementos necessários ao planejamento das atividades a serem desenvolvidas, devendo-se considerar as esferas econômicas, políticas e sociais, que no caso do sistema de classificação compilado não foram contempladas.

As categorias do sistema de classificação em capacidade de uso estão hierarquizadas da seguinte forma:

- Grupos de capacidade de uso (A, B e C): estabelecidos com base nos tipos de intensidade de uso das terras;

- Classes de capacidade de uso (I a VIII): baseadas no grau de limitação de uso;

- Subclasses de capacidade de uso (lle, llle, llla etc): baseados na natureza da limitação do uso;

- Unidades de capacidade de uso (Ile-1, Ile-2, Ille-1 etc): baseados em condições específicas que afetam o uso ou manejo da terra.

\subsubsection{Grupos de capacidade de uso}

Os grupos de capacidade de uso, que constituem categorias de nivel mais elevado, mais generalizado, são estabelecidos com base na maior ou menor intensidade de uso das terras, designada, em ordem decrescente pelas letras $A, B$ e $C$.

- Grupo A: terras passiveis de utilização com culturas anuais, perenes, pastagens e/ou reflorestamento e vida silvestre (comporta as classes I, II, III e IV).

- Grupo B: terras impróprias para cultivos intensivos, mas ainda aptas para pastagens e/ou reflorestamento e/ou vida silvestre (Compreende as classes V, VI e VII).

- Grupo C: terras não adequadas para cultivos anuais, perenes, pastagens ou reflorestamento, porém apropriadas para proteção da flora e fauna silvestre, recreação ou armazenamento de água (comporta a classe VIII). 


\subsubsection{Classes de capacidade de uso}

Consistem em agrupamentos de terras apresentando o mesmo grau de limitação, ou seja, terras com limitações de uso e/ou riscos de degradação do solo em grau semelhante.

As classes de capacidade de uso são em número de oito, convencionalmente designadas por algarismos romanos, em que a intensidade de uso é decrescente no sentido I-VIII, conforme ilustrado na Figura 5.5 .

\begin{tabular}{|c|c|c|c|c|c|c|c|c|c|}
\hline \multirow{4}{*}{$\begin{array}{c}\text { SENTIDO } \\
\text { DAS } \\
\text { APTIDÕES } \\
\text { E DAS } \\
\text { LIMITAÇÕES }\end{array}$} & \multirow{4}{*}{ 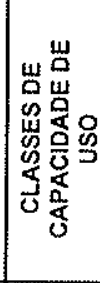 } & \multicolumn{2}{|c|}{ SENTIDO } & 0 AUME & $\begin{array}{ll}\mathrm{NTO} & \mathrm{DA} \\
\end{array}$ & INTENSI & $\overline{A D E} \quad D E$ & USO & $\sum$ \\
\hline & & \multirow{3}{*}{$\begin{array}{l}\text { VIDA } \\
\text { SILVESTRE } \\
\text { E } \\
\text { RECREAÇĀO }\end{array}$} & \multicolumn{3}{|c|}{ SILVICULTURA PASTOREIO } & \multirow{3}{*}{$\begin{array}{l}\text { CULTVVO } \\
\text { OCASIONAL } \\
\text { OU } \\
\text { LIMITADO }\end{array}$} & \multirow{2}{*}{\multicolumn{3}{|c|}{$\begin{array}{l}\text { CULTIVO INTENSIVO } \\
\text { PROBLEMA DE CONSERVAÇAO }\end{array}$}} \\
\hline & & & \multirow{2}{*}{ LIMITADO } & \multirow{2}{*}{ MODERADO } & \multirow{2}{*}{ INTENSIVO } & & & & \\
\hline & & & & & & & COMPLEXO & SIMPLES & $\begin{array}{c}\text { NAO } \\
\text { APARENTE }\end{array}$ \\
\hline & 1 & & & & & & & & \\
\hline$x_{0}$ & II & & & & & & & & \\
\hline 送总 & III & & & & & & & & \\
\hline 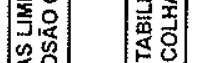 & IV & & & & & & & & \\
\hline $\mid$ & v & & & & & & & & \\
\hline 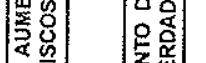 & VI & & & & & & & & \\
\hline 容受 & VII & & & & & & & & \\
\hline & VIII & & & & & & & & \\
\hline
\end{tabular}

Figura 5.5 - Classes de capacidade de uso e relações com aptidão e limitações conforme utilização da terra (Lepsch, 1990).

A caracterização das classes de capacidade de uso leva em conta principalmente a maior ou menor complexidade das práticas conservacionistas, em especial as de controle a erosão. As práticas de conservação do solo, usualmente definidas como o conjunto de medidas destinadas a controlar a erosão e outras formas de depauperamento do solo, de modo a mantê-lo permanentemente produtivo, podem ser subdivididas em: a) práticas de controle à erosão; e b) práticas complementares de melhoramento.

a) práticas de controle à erosão: destinadas a diminuir o processo erosivo, isto é, desagregação, transporte e deposição de partículas do solo, causado pelas forças de impacto direto das gotas de chuva, pela enxurrada e pelo vento, provocando o desgaste e rebaixamento do perfil do solo localizado nas partes mais elevadas e, eventualmente, o acúmulo de sedimentos sobre aquele localizado em condições de 
cotas mais baixas. Dentre as mais difundidas, estão o terraceamento, plantio e cultivo em nivel, faixas de retenção ou de rotação e canais divergentes;

b) práticas complementares de melhoramentos: procuram melhorar ou recuperar as condições de produtividade das terras e racionalizar ao máximo o uso do solo. Normalmente, atuam indiretamente no controle da erosão, por causa do aumento promovido no enraizamento e na cobertura do solo, ocasionado pelo maior desenvolvimento das plantas cultivadas. Como exemplos, citam-se: calagem, adubações químicas, adubação verde, rotação de culturas, subsolagem, drenagem, divisão e manejo das pastagens.

As classes de capacidade de uso dos grupos A, B e C, podem sem caracterizadas sinteticamente da seguinte forma:

\subsubsection{Grupo A}

- Classe I: terras cultiváveis, aparentemente sem problemas especiais de conservação;

- Classe II: terras cultiváveis com problemas simples de conservação e/ou de manutenção de melhoramentos;

- Classe III: terras cultiváveis com problemas complexos de conservação e/ou manutenção de melhoramentos;

- Classe IV: terras cultiváveis apenas ocasionalmente ou com extensão limitada, com sérios problemas de conservação;

\subsubsection{Grupo B}

- Classe V: terras aptas em geral para pastagens e, em alguns casos, para reflorestamento, sem necessidade de práticas especiais de conservação, são cultiváveis apenas em casos muito especiais;

- Classe VI: terras adaptadas em geral para pastagens e/ou reflorestamento, com problemas simples de conservação. São cultiváveis apenas em casos especiais de algumas culturas permanentes protetoras do solo;

- Classe VII: terras adaptadas em geral somente para pastagens ou reflorestamento, com problemas complexos de conservação;

\subsubsection{Grupo C}

- Classe VIII: terras impróprias para cultura, pastagem ou reflorestamento, podendo servir apenas como abrigo e proteção da fauna e flora silvestre, como ambiente para recreação, ou para fins de armazenamento de água. 


\subsubsection{Subclasses de capacidade de uso}

As subclasses representam classes de capacidade de uso qualificadas em função da natureza da limitação, tornando mais explicitas as práticas ou grupos de práticas conservacionistas a serem adotadas.

A natureza da limitação é designada por letras minúsculas, de modo que a subclasse de capacidade de uso é representada pelo algarismo romano (da classe) seguido da letra designativa do fator limitante. Por exemplo, Ille representa a classe III com problema de erosão. Como só pode apresentar limitações ligeiras, a classe I não admite subclasse.

Convencionalmente, as limitações de uso podem ser de quatro naturezas:

e: limitações pela erosão presente e/ou risco de erosão;

s: limitações relativas ao solo;

a: limitaçöes por excesso de água;

c: limitações climáticas.

Observa-se que, por intermédio das classes de capacidade de uso, pode-se estabelecer as alternativas de uso e a intensidade das práticas conservacionistas (exemplo: classe III subentende culturas com práticas complexas de conservação). Entretanto, para definir a natureza das práticas, é preciso conhecer a natureza da limitação dominante, ou seja, a subclasse. Assim, uma subclasse llle pode representar uma gleba que, sob culturas, requer práticas complexas de controle da erosão.

\subsection{Grupos de manejo}

Também são denominados unidades de manejo ou unidades de uso, representam agrupamentos de terra que deverão receber idêntico manejo agrícola, em decorrência dos solos apresentarem as mesmas respostas aos processos de tratamento, com adaptações análogas de plantio e colheita, além dos mesmos riscos e limitações de uso agrícola.

Os grupos de manejo apresentam um agrupamento de classes que podem diferir em função do tipo de utilização de terra, principalmente em relação ao tipo vegetal que será cultivado. Assim, por exemplo, para o plantio de culturas como cacau, cana-deaçúcar, mandioca, milho ou algodão, diferentes grupos de manejo podem ser estabelecidos, em uma mesma gleba, porque as necessidades dessas espécies em nutrição e a proteção que proporcionam ao solo são muito diversas. Por outro lado, no caso de usos menos intensivos da terra, como reflorestamento, pastagens ou cultivos permanentes protetores do solo, é comum que terras situadas até em classes de 
capacidade de uso diferentes, possam ser enquadradas em uma idêntica unidade de manejo.

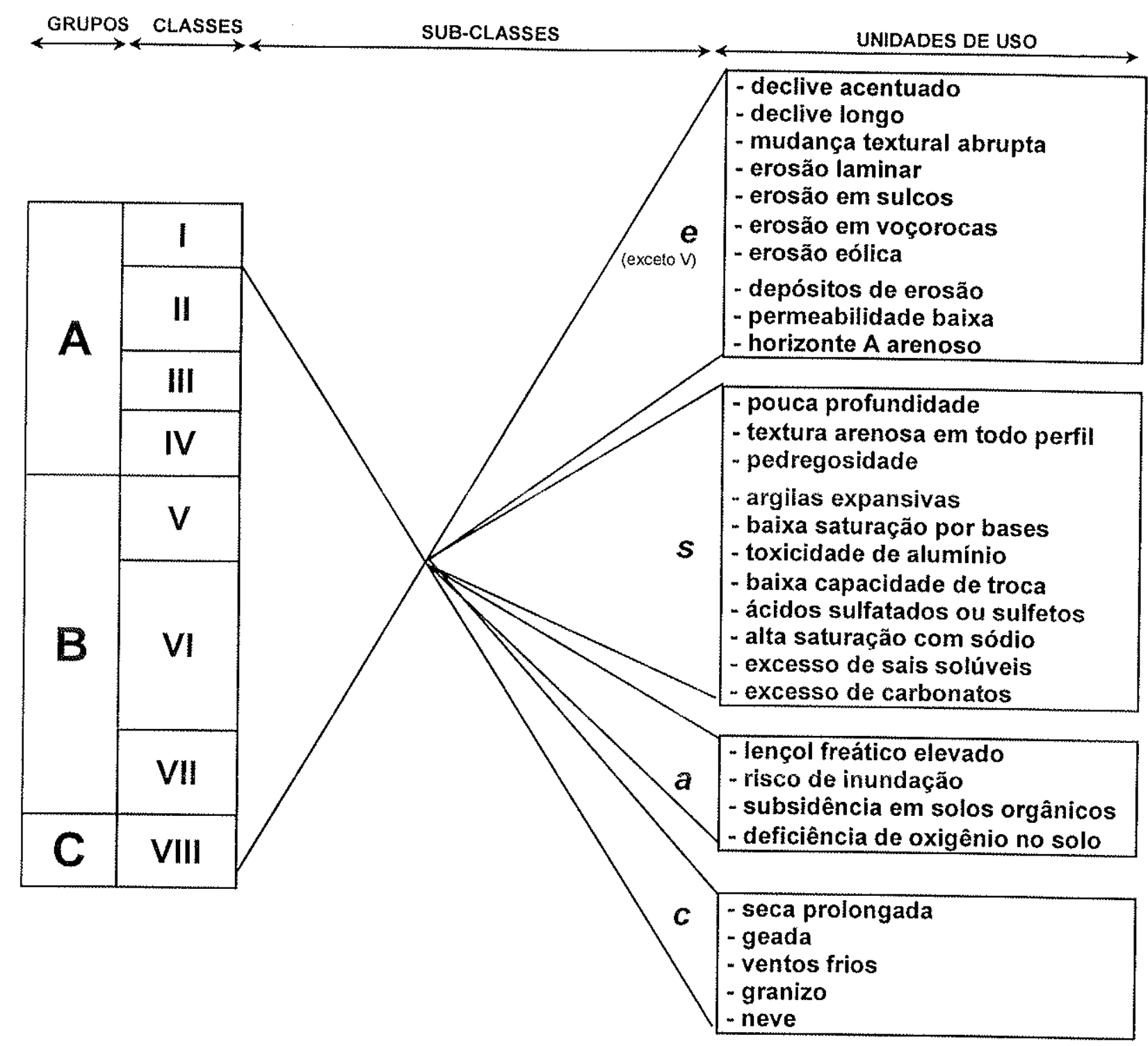

Figura 5.6 - Esquema dos grupos, classes, subclasses e unidades de capacidade de uso (Peralta, 1963, apud Lepsch 1991).

Evidentemente os grupos de manejo são determinados para cada área estudada e não podem ser aplicados de forma genérica, e sim para cultivos específicos. De forma geral, em áreas extensas que serão submetidas a um único tipo de cultivo (p.e. cana-de-açúcar ou reflorestamento), ou combinação especifica de cultivos (p.e. rotação contínua trigo-soja) deve-se estabelecer unidades de uso, ou grupos de manejo, especificamente adequados aos projetos a serem implantados e em função da realidade presente. 


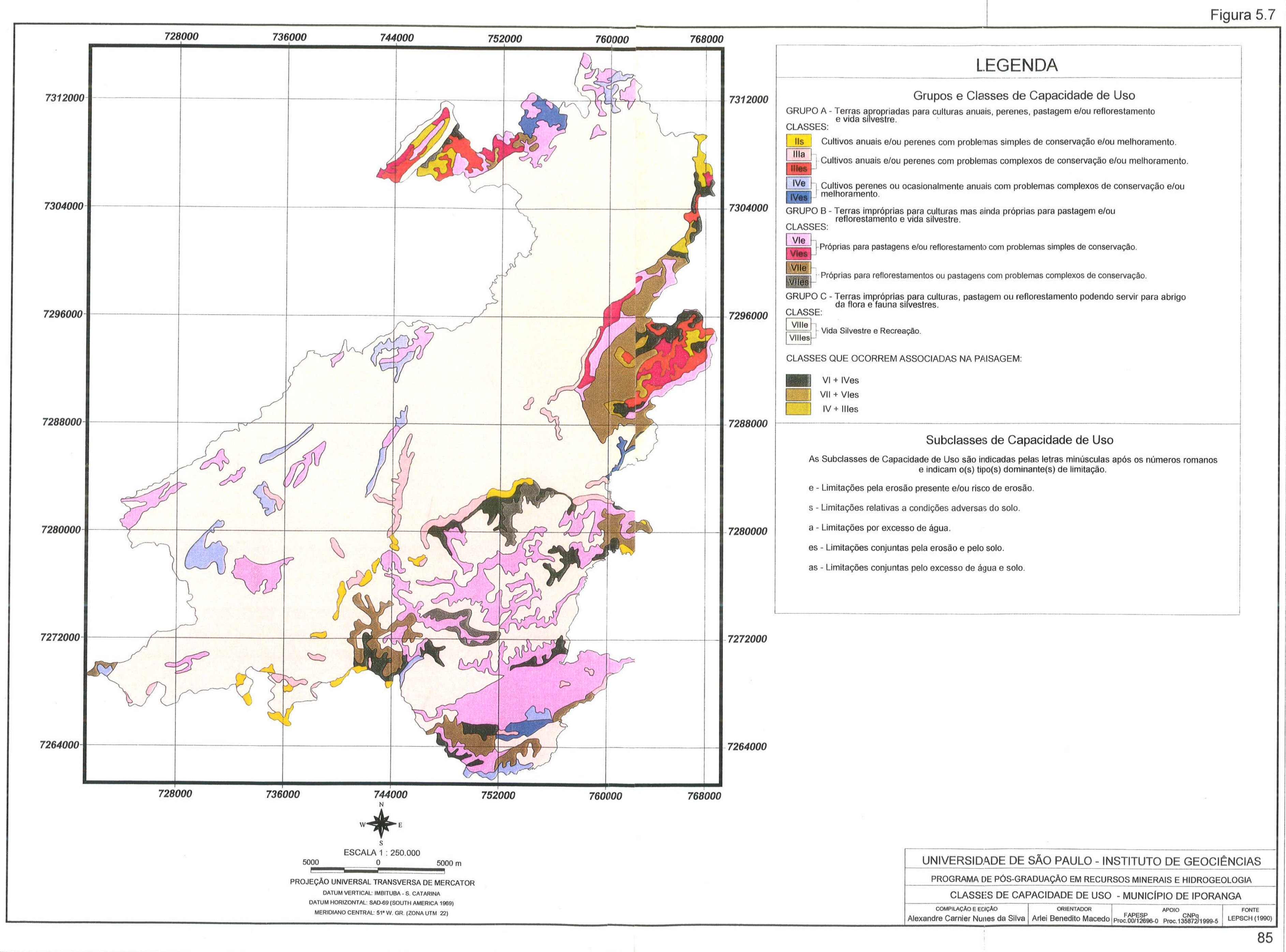




\section{CAPÍTULO 6 - MÉTODOS}

\section{Programas utilizados}

As atividades desenvolvidas em geoprocessamento utilizaram, para entrada de dados, os programas da familia Intergraph: IRAS-B, I-GeoVec e MicroStation; para processamento e edição topológica o programa ARC-INFO 7.2 NT (ESRI); na análise dos dados o programa IDRISI32 (Clark Labs); e para apresentação dos resultados o programa ArcView 3.1 (ESRI).

As atividades de processamento e tratamento dos dados de sensoriamento remoto utilizaram os programas ER Mapper 5.5 (Earth Resource Mapping) e ENVI 3.2 (Research Systems, Inc.). A apresentação dos resultados também utilizou o programa ArcView 3.1 (ESRI).

\subsection{Geoprocessamento}

\subsubsection{Entrada de dados}

Os procedimentos de entrada de dados, quando possivel empregaram a representação contínua do espaço, ou seja, a representação vetorial. Mapas temáticos e bases cartográficas foram convertidas em formato vetorial utilizando o processo inicialmente de rasterização e posteriormente de vetorização. Em alguns casos o plano de informação é um dado com estrutura discreta, como imagens de satélite e outros produtos de sensoriamento remoto, sendo então armazenados pelo sistema no formato matricial.

A entrada de dados vetoriais foi realizada utilizando-se os programas I/GEOVEC e IRAS-B da família INTERGRAPH, ambos programas funcionam diretamente sobre o MicroStation, que é um sistema CAD (Computer Aided Drawing), sendo o primeiro utilizado para a vetorização semi-automática e o segundo para edição preliminar e gerenciamento dos arquivos gráficos.

\subsubsection{Preparação dos originais}

O processo de compilação das bases disponiveis em meio analógico (papel) utilizou o procedimento de cópia manual, em película indeformável (poliéster), quando o mapa original não apresentava qualidade suficiente para ser utilizado diretamente no processo de vetorização. A cópia contendo os contornos de interesse e pontos de 
controle dispersos é rasterizada ${ }^{4}$ com resolução de $400 d p i$ e convertida para o formato RLE - Intergraph, que é utilizado como padrão no l/GEOVEC.

No módulo IRAS-B a imagem é georreferenciada através do comando 'Warp'. Durante o processamento 'Warp' são visualizados inicialmente 'dois arquivos' na área de trabalho (Figura 6.1):

- Arquivo de desenho vetorial com extensão .DGN: é a própria área de trabalho que possui os atributos de coordenadas, referências geográficas, elipsóide, sistema de projeção, datum, "unidades de trabalho" ('working units'), entre outros, devidamente ajustados para conter a área relativa ao projeto.

- Arquivo rasterizado com extensão .RLE: arquivo a ser reajustado, que está sobreposto aleatoriamente sobre a área de trabalho.

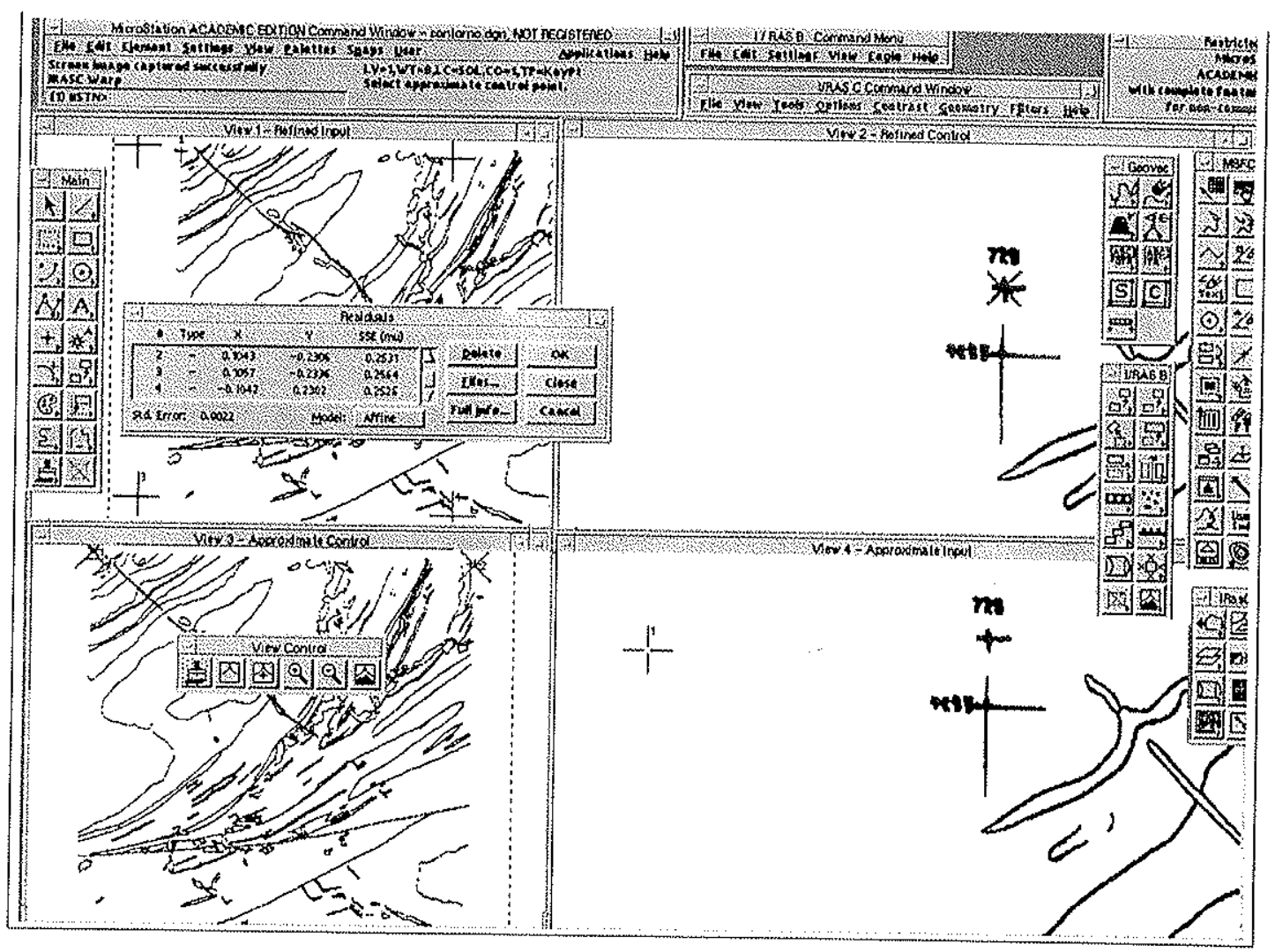

Figura 6.1 - Georreferenciamento da película rasterizada através do processamento Warp no módulo IRAS-B ( $X$ indicam os pontos a serem ajustados; + indicam as coordenadas de referência;).

Estando pelo menos quatro pontos de coordenadas conhecidas lançados no arquivo de desenho, o comando 'Warp' pode ser ativado e os quatro pontos, com coordenadas conhecidas, são então selecionados inicialmente na imagem (com o

\footnotetext{
4 Termo utilizado por Teixeira \& Christofoletti (1997) para o processo de transformação do formato analógico para o formato digital utilizando a estrutura raster (scanning).
} 
auxílio do 'zoom') e posteriormente no arquivo de desenho, sendo que o erro de reajuste é demonstrado automaticamente durante o processo, que pode ser repetido até se alcançar o número de pontos e erro aceitáveis.

Com esse procedimento a imagem está georreferenciada, ou seja possui as mesmas referências do arquivo de desenho, estando pronta para o processo de vetorização semi-automática no I/GEOVEC.

\subsubsection{Vetorização semi-automática}

Os processos de vetorização podem ser automáticos, semi-automáticos e manuais. O processo de digitalização em mesa pode empregar alguns recursos de captura de dados (comando sketch no AutoCAD), contudo, constitui um processo manual que apresenta limitações na relação de escala dos dados de entrada e saída, qualidade variando em função do tempo de digitalização, e experiência do operador, sujeito a erros sistemáticos e operacionais. Os resultados obtidos, de maneira geral, apresentam qualidade inferior aos resultados obtidos por processos semi-automáticos.

No programa I/GEOVEC, através da ferramenta Geo Tracing Linestring, é feita a vetorização semi-automática das linhas rasterizadas. Esse comando traça automaticamente vetores, exatamente no centro do contorno do arquivo rasterizado (Figura 6.2) de forma ininterrupta até que encontre espaços vazios ou bifurcações onde procede conforme a configuração pré-determinada, parando ou continuando à direita ou à esquerda (Figura 6.3).

\subsubsection{Controle de erro}

No processo de digitalização semi-automática a mesa digitalizadora é

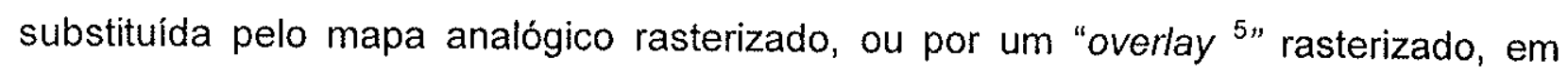
Scanner $P \& B$ de grandes dimensões $(A 0)$ com alta resolução (300-600 dpi), o que permite a reprodução precisa em meio digital (no formato matricial).

Nesse processo a resolução utilizada deve ser no mínimo $127 \mathrm{dpi}$ (1 pol / 0,2cm $=254$ (2), independentemente da escala do mapa, o que corresponde no papel a uma amostragem de um ponto a cada $0,2 \mathrm{~mm}$, o máximo de detalhe que o olho humano consegue distinguir. Contudo, a resolução de 300 a 400dpi geralmente é empregada para se obter melhor qualidade na eventual reprodução do material e melhor definição de detalhes durante o processo de vetorização. Em bases com baixa qualidade pode-

\footnotetext{
${ }^{5}$ Cópia transparente em poliéster ou outro tipo de película indeformável.
} 
se utilizar resoluções da ordem de 600dpi na tentativa de obter melhor definição em detalhes


Figura 6.2 - Vetorização semi-automática do arquivo rasterizado no programa
I/GEOVEC.

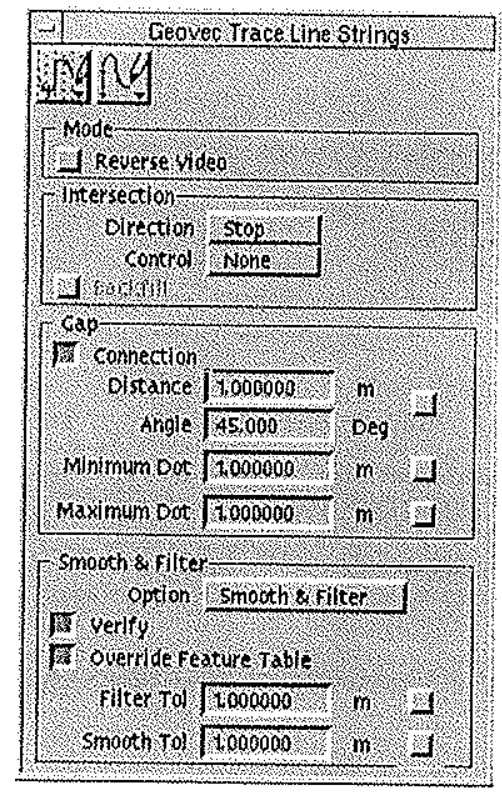
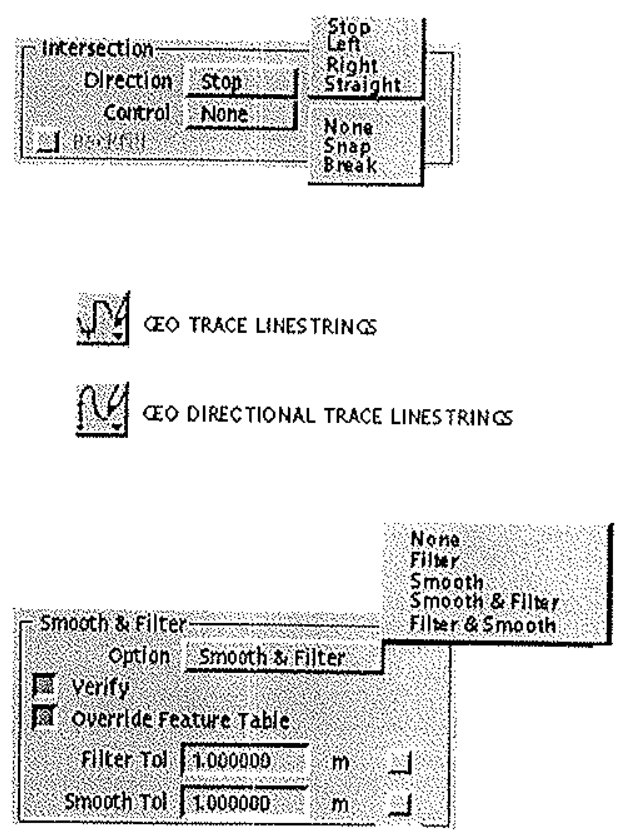

Figura 6.3 - Opções de padronização do processo de vetorização semi-automática disponiveis no programa I/GEOVEC. 
Os objetivos a serem alcançados pela digitalização devem ser definidos antes do inicio do trabalho e deve-se também definir o grau de precisão que o produto final deve alcançar. As distorções nas bases de dados são inerentes a cada fonte e divergem entre si. Nesse caso, deve-se selecionar uma base de dados considerada a mais correta, para assim relacionar os outros dados a esta base, fazendo as eventuais correções através de processos matemáticos (Guimarães Filho, 1994).

A Tabela 6.1 apresenta os erros admitidos no processo de entrada de dados, segundo Guimarães Filho (1994). O processo de ajuste da base deve ser refinado até que se obtenha um erro inferior ao RMS máximo permitido, conforme a escala de trabalho. O espaçamento entre pontos deve ser considerado na configuração dos processos de vetorização, seja manual ou semi-automático, para que o produto final apresente qualidade compatível com a escala.

O Erro Padrão (EP) e o Padrão de Exatidão Cartográfica (PEC) estão relacionados no decreto 89.817 de 20/06/1984, que define as Instruções Reguladoras das Normas Técnicas da Cartografia Nacional e apresenta um padrão de classificação de cartas (classe $A, B$ e C) conforme o erro presente, sendo que os dados apresentados referem-se ao padrão A (o valor do PEC corresponde a $0.5 \mathrm{~mm}$, e o EP a $0.3 \mathrm{~mm}$, na escala da carta).

A digitalização das cartas topográficas IBGE 1:50.000 da área que compreende o município de Iporanga (totalizando 5 cartas), foi realizado dentro destes padrões. Os temas de curvas de nivel foram digitalizados conjuntamente com os principais elementos cartográficos como drenagens, estradas pavimentadas, estradas não pavimentadas, entre outros.

Tabela 6.1 - Valores aceitáveis de erro em bases cartográficas conforme escala.

\begin{tabular}{|c|c|c|c|c|c|c|}
\hline ESCALA & $\begin{array}{c}1 \mathrm{~cm} \\
\text { na carta }\end{array}$ & $\begin{array}{c}1 \mathrm{~mm} \\
\text { na carta }\end{array}$ & $\begin{array}{c}\text { RMS } \\
\text { Erro Máximo } \\
\end{array}$ & $\begin{array}{l}\text { Espaçamento } \\
\text { entre pontos }\end{array}$ & $\begin{array}{c}\text { Erro } \\
\text { Padrão } \\
\end{array}$ & PEC ${ }^{\circ}$ \\
\hline $1: 1.000$ & $10 \mathrm{~m}$ & $1 \mathrm{~m}$ & $0,254 \mathrm{~m}$ & $0,508 \mathrm{~m}$ & $0,3 \mathrm{~m}$ & $0,5 \mathrm{~m}$ \\
\hline $1: 5.000$ & $50 \mathrm{~m}$ & $5 \mathrm{~m}$ & $1,27 \mathrm{~m}$ & $2,54 \mathrm{~m}$ & $1,5 \mathrm{~m}$ & $2,5 \mathrm{~m}$ \\
\hline $1: 10.000$ & $100 \mathrm{~m}$ & $10 \mathrm{~m}$ & $2,54 \mathrm{~m}$ & $5,08 \mathrm{~m}$ & $3,0 \mathrm{~m}$ & $5 \mathrm{~m}$ \\
\hline $1: 25.000$ & $250 \mathrm{~m}$ & $25 \mathrm{~m}$ & $6,35 \mathrm{~m}$ & $12,7 \mathrm{~m}$ & $7,5 \mathrm{~m}$ & $12,5 \mathrm{~m}$ \\
\hline $1: 50.000$ & $500 \mathrm{~m}$ & $50 \mathrm{~m}$ & $12,7 \mathrm{~m}$ & $25,4 m$ & $15 \mathrm{~m}$ & $25 \mathrm{~m}$ \\
\hline $1: 100.000$ & $1000 \mathrm{~m}$ & $100 \mathrm{~m}$ & $25,4 \mathrm{~m}$ & $50,8 \mathrm{~m}$ & $30 \mathrm{~m}$ & $50 \mathrm{~m}$ \\
\hline $1: 250.000$ & $2500 \mathrm{~m}$ & $250 \mathrm{~m}$ & $63,5 \mathrm{~m}$ & $127 m$ & $75 \mathrm{~m}$ & $125 \mathrm{~m}$ \\
\hline
\end{tabular}

(b) Dec. 89.817 - 20/06/1984 - Instruçбes Reguladoras das Normas Técnicas da Cartografia Nacional; 


\subsection{Análise espacial em SIGs}

Seguindo Bonham-Carter (1996) o propósito final da maioria dos projetos em SIG é combinar dados espaciais de diferentes fontes em um produto integrado, de forma a descrever e analisar interações, fazer previsões com base em modelos, e proporcionar suporte à tomada de decisão. A forma com que esses modelos são implementados apresenta grande variação, estando esta diretamente ligada aos objetivos imediatos do analista, e aos dados disponiveis para análise.

A seleção de áreas mais adequadas para diversos usos envolve a busca de regiōes que satisfaçam uma série de critérios. Se os critérios são definidos como uma série de regras determinísticas, o modelo consiste na aplicação de operadores booleanos para uma série de mapas de entrada, resultando em um mapa binário, que define as áreas que satisfazem todos os critérios empregados ou não. Alternativamente, cada área pode ser avaliada de acordo com um critério de atribuição de pesos, resultando em uma escala classificatória de adequabilidade ou aptidão da área para determinado modelo.

O processo de seleção de áreas aptas que se segue é então favorecido por essa escala classificatória de aptidão gerada, permitindo uma melhor distinção que vai além da simples separação entre apto/inapto, permitindo o reconhecimento do padrão espacial de suscetibilidade ou aptidão de uma área.

Os modelos utilizados para a seleção de áreas geralmente são do tipo prescritivo, ou seja envolvem a aplicação de uma série de critérios que são considerados tecnicamente como práticas recomendadas de engenharia, resultado de uma união de fatores científicos, econômicos e sociais. Outro modelo bastante utilizado em geociências é o modelo preditivo, utilizado no mapeamento do potencial mineral, que tem como propósito encontrar novos depósitos (Bonham-Carter, 1996).

Seguindo a abordagem de Bonham-Carter (1996), cada um dos modelos é detalhado nos itens seguintes.

\subsubsection{Tipos de modelos}

Embora seja dificil a classificação dos modelos em SIG, é bastante útil a distinção entre três tipos baseando-se nas relações que os modelos representam, como mostrado na Tabela 6.2. 
Tabela 6.2 - Classificação dos modelos utilizados em geologia.

\begin{tabular}{|c|c|c|c|}
\hline \multirow{2}{*}{ Classe } & \multirow{2}{*}{$\begin{array}{l}\text { Tipo de } \\
\text { relacionamento }\end{array}$} & \multicolumn{2}{|c|}{ Exemplo } \\
\hline & & Campo de aplicação & Modelo \\
\hline Teórico & $\begin{array}{c}\text { Físico / Principios } \\
\text { químicos }\end{array}$ & $\begin{array}{l}\text { Modelagem de fluxo } \\
\text { da água subterrânea }\end{array}$ & Equaçöes de movimento \\
\hline Híbrido & Semi-empirico & $\begin{array}{c}\text { Transporte de } \\
\text { sedimentos }\end{array}$ & Equações de transporte \\
\hline Empírico & $\begin{array}{l}\text { Heurístico ou } \\
\text { estatistico }\end{array}$ & Previsão mineral & Regressão estatística \\
\hline
\end{tabular}

A construção de modelos em SIG pode ser entendida, de forma geral, como um processo de combinação de uma série de mapas de entrada utilizando-se uma função para se produzir um mapa de saída.

Bonham-Carter (1996) assume a seguinte aproximação:

\section{Mapa de saída $=f(2$ ou mais mapas de entrada)}

A função $f$, toma muitas formas diferentes, mas as relações expressas pela função são baseadas em uma compreensão teórica de princípios físicos e químicos, ou empíricos baseados na observação de dados, ou em uma mistura de teoria e empirismo.

A abordagem que utiliza relações semi-empiricas é utilizada em muitos campos das geociências, por exemplo, em modelos de processos de deslizamentos, e em modelos de simulação de sedimentação. Em aplicações de SIG, na área de estabilidade de encostas e deslizamentos, Bonham-Carter (1996) cita os trabalhos de Wadge (1988) e Van Westen (1993), que empregaram modelos físicos, empíricos e uma abordagem intermediária semi-empírica, que se revelou eficiente na modelagem e mapeamento da estabilidade de encostas utilizando-se uma variedade de mapas de entrada, tais como declividade, profundidade de solos, coesão do solo e nivel d'água.

Modelos para a previsão do potencial mineral, baseados em relacionamento estatístico ou heurístico, são exemplos de modelos empíricos. Os princípios físicos e químicos responsáveis pela formação dos depósitos minerais são em sua maior parte muito complexos para uma previsão direta a partir de expressões teóricas expressas matematicamente. A previsão de depósitos minerais deve se basear principalmente nos relacionamentos empíricos, com o auxílio de "modelos descritivos do depósito".

$\mathrm{Na}$ aplicação de SIG ao mapeamento da suscetibilidade natural do meio físico, o modelo do processo analisado participa diretamente de todas as etapas, desde a seleção de temas de entrada, geração de mapas derivados a serem utilizados como fatores, até a fase de atribuição de pesos na combinação dos fatores. 
A atribuição de pesos pode seguir um critério estatístico, utilizando um estudo prévio para estimar o relacionamento espacial entre os mapas de fatores gerados e as respostas reais da área de interesse (estimado com base em ocorrência de processos), ou os pesos podem ser estimados com base na opinião de especialistas. Esses dois tipos de abordagem são chamadas de: abordagem dirigida pelos dados "data-driven", e abordagem dirigida pelo conhecimento "knowledge-driven", como apresentado na Tabela 6.3.

No modelo de abordagem com base nos dados, os vários mapas de entrada são combinados utilizandomse modelos, tais como regressão lógica (logistic regression), pesos de evidência (wheights of evidence), ou análise de redes neurais (neural network analysis). Modelos de análise baseados no conhecimento incluem o uso de lógica difusa (fuzzy logic), probabilidade bayesiana (Bayesian probability), e teoria de aceitação Dempster-Shafer (belief).

Tabela 6.3 - Abordagens da modelagem de dados aplicada em SIG, divididos em modelos baseados no conhecimento (knowledge-driven) e nos dados (data-driven).

\begin{tabular}{|c|c|c|}
\hline Tipo & Parâmetros & Exemplo \\
\hline $\begin{array}{c}\text { Baseado nos dados } \\
\text { (Data-driven) }\end{array}$ & $\begin{array}{c}\text { Calculados a } \\
\text { partir de dados } \\
\text { de treinamento }\end{array}$ & $\begin{array}{c}\text { Regressão lógica (logistic regression) } \\
\text { Pesos de evidência (wheights of evidence) } \\
\text { Redes neurais (neural network analysis) }\end{array}$ \\
\hline $\begin{array}{c}\text { Baseado no } \\
\text { conhecimento } \\
\text { (Knowledge-driven) }\end{array}$ & $\begin{array}{c}\text { Estimados por } \\
\text { especialistas }\end{array}$ & $\begin{array}{c}\text { Tógica difusa (fuzzy logic) } \\
\text { Teoria de aceitaçäo Dempster-Shafer (Dempster- } \\
\text { Shafer belief) }\end{array}$ \\
\hline
\end{tabular}

Fonte: Bonham-Carter (1996)

Algumas aplicações da modelagem baseada no conhecimento, para a exploração dos dados empregando técnicas de geoprocessamento, visando a caracterização do meio-físico, pode ser encontrada em Eastman $(1995,1997)$, Nunes da Silva (1998), Araújo (1999), Pedro (1999) e Liotte (2000).

\subsubsection{Aplicação de Modelos de integração de dados}

A elaboração de modelos conceituais para a integração de mapas pode empregar operações lógicas distintas que compartilham o mesmo objetivo de combinar os dados, apresentando contudo resultados bastante distintos.

\subsubsection{Lógica booleana}

Provavelmente as operações lógicas em SIG mais simples e melhor conhecidas são as chamadas operações booleanas. O modelo lógico booleano envolve a combinação lógica de mapas binários resultantes da aplicação de operadores 
condicionais. Cada um dos mapas utilizados como condição pode ser pensado como um plano de informação de evidência. Os vários planos de informação de evidência são combinados para dar suporte a uma hipótese, ou proposição. Desse modo a hipótese a ser avaliada na locação de uma área para aterro, por exemplo, seria "esta área é adequada para a instalação de um aterro".

Cada porção da região analisada é então testada para determinar se pertence ao conjunto de áreas para as quais os critérios são satisfeitos. A associação com esse conjunto é expressa por 1 ou 0 , sem nenhuma possibilidade de "talvez". A hipótese é avaliada repetitivamente por toda a região analisada no estudo, resultando em um mapa de hipóteses binário. Na linguagem de conjuntos, a associação é expressa somente com valores binários 1 (VERDADEIRO) ou 0 (FALSO).

$O$ ponto forte da abordagem booleana é sua simplicidade. A combinação lógica de mapas em um SIG é diretamente análoga a sobreposiçăo física de mapas em uma mesa de luz, o método tradicional empregado por muitos geólogos. Nos casos em que normas são prescritas por códigos ou leis, as combinações booleanas constituem práticas facilmente aplicadas. Na prática, contudo, essa abordagem geralmente é inadequada por atribuir a mesma importância para cada um dos critérios que estão sendo combinados. As evidências conhecidas precisam ser ponderadas conforme sua significância relativa. Por exemplo, na análise de aptidão aos diversos usos, a baixa suscetibilidade aos movimentos de massa é um indicador mais importante, da aptidão da área, do que a distância às estradas. Em uma abordagem com lógica booleana ambas evidências são tratadas com a mesma importância.

\subsubsection{2 Índices somativos}

O método de modelagem por índices somativos apresenta a vantagem de permitir que cada mapa de evidência seja tratado de forma diferenciada, através da atribuição de diferentes pesos, dependendo da sua significância para a hipótese sob consideração.

O tipo mais simples de indice somativo é o que emprega mapas binários como entrada, ou seja, cada mapa apresenta uma única classe, recebendo portanto uma ponderação única. Contudo, mapas com múltiplas classes (desde categóricos, até com elevado nivel de mensuração) são utilizados, cada classe dos mapas de entrada recebe uma pontuação, permitindo um sistema de ponderação mais flexivel. 


\subsection{Mapas de evidência binários (Binary Wheights)}

Caso a evidência a ser combinada seja binária, cada mapa é simplesmente multiplicado por seu peso, somado com todos os mapas que estão sendo combinados e normalizado pela soma dos pesos. O resultado é um valor entre 0 e 1 , o qual pode ser reclassificado em intervalos apropriados para visualização. Em qualquer região, a pontuação final obtida, $S$, é definida como:

$$
S=\frac{\sum_{i}^{n} w_{i} \operatorname{class}\left(M A P_{i}\right)}{\sum_{i}^{n} w i}
$$

onde $w_{i}$ é o peso do i-ésimo mapa, e class $\left(M A P_{i}\right)$ é 1 para a presença ou 0 para ausência da condição binária.

A pontuação de saída está entre 0 (implicando em uma área extremamente inadequada) para 1 (implicando em uma área altamente adequada). O resultado é então apresentado através de uma ordenação das áreas de acordo com a pontuação.

\subsection{Mapas de evidência multi-classe (Index overlay)}

Nesse caso, a cada classe que compõe os mapas de evidência são atribuídas pontuações diferentes, bem como a cada mapa, que receberá um peso diferente como no procedimento anterior. Nesse processo é conveniente a utilização de uma tabela que descreve os atributos de cada mapa e define cada pontuação. A pontuação média é então definida por:

$$
\bar{S}=\frac{\sum_{i}^{n} s_{i j} w_{i}}{\sum_{i}^{n} w_{i}}
$$

onde $S$ é a pontuação ponderada resultante na combinação (área representada por poligonos, pixels), $w_{i}$ é o peso do i-ésimo mapa, e $S_{i j}$ é a pontuaçāo para a j-ésima classe do i-ésimo mapa, o valor de $j$ depende da ocorrência da classe em cada porção analisada.

Cada mapa deve estar associado com uma lista de pesos, um para cada classe do mapa. Os pesos de cada mapa são utilizados como no procedimento dos mapas de evidência binários, mas ao invés de aplicar declarações condicionais para determinar uma condição binária, a pontuação é obtida a partir da tabela de pesos para cada 
mapa, dependendo das classes do mapa presentes na porção da área em consideração.

A aplicação de pontuações e pesos, para cada classe e mapa, respectivamente, envolve a utilização de um mesmo esquema de análise para cada mapa, por exemplo, as pontuações podem variar de 0 (menos apto) até 10 (mais apto). As pontuações não devem variar de 0-1 em um mapa, e 0-100 para outro mapa. Pesos e pontuações não estão restritos a valores inteiros. No caso de áreas restritivas, conforme o programa utilizado, pode-se utilizar uma pontuação específica, por exemplo, o valor -1 , que indica a exclusão da área em questão, independentemente da sua aptidão em outros mapas empregados na análise.

A utilização do método por índices somativos com mapas de evidência multiclasse permite uma combinação mais flexivel de mapas do que é possivel utilizando-se somente as operações lógicas booleanas. As tabelas de pontuação das classes e os pesos de cada mapa podem ser ajustados para refletir a opinião de um especialista na área de aplicação sob consideração. As pontuações podem utilizar números inteiros positivos, ou números reais, sem nenhum limite na variação numérica, exceto que a variação deve ser compativel entre os mapas, assegurando a equivalência entre a pontuação atribuída a cada tema.

A maior desvantagem deste método recai provavelmente sobre a sua natureza linear. A abordagem da Lógica difusa (Fuzzy logic) é em muitos aspectos similar, mas as regras de combinação são mais flexíveis, e apresenta melhorias em relação à natureza linear do método.

\subsubsection{Lógica Difusa (Fuzzy logic)}

Na teoria clássica de conjuntos, que emprega lógica booleana, a associação de um conjunto é definida como verdadeira ou falsa, 1 ou 0 . A associação de um conjunto difuso (fuzzy set) é expressa em uma escala contínua de 1 ("completamente verdadeiro") para 0 ("completamente falso").

Bonham-Carter (1996) exemplifica a aplicação da lógica difusa na modelagem de áreas com anomalias de arsênio (As) utilizando medidas em amostras de sedimentos de um lago. As medidas de As efetuadas são então associadas ao conjunto chamado "anomalias de arsênio", de acordo com o grau de associação que possuem. Os valores muito altos de As são considerados anômalos apresentando uma associação difusa (fuzzy membership) de 1, enquanto valores extremamente baixos ou abaixo de um limiar possuem uma associação difusa de 0 , entre estes extremos existe 
uma variedade de possíveis valores de associações. Essa função de associação pode ser expressa analiticamente como:

$$
\mu(x)=\left\{\begin{array}{lll}
0 & \text { Se } \quad x<50 \\
\frac{x-50}{200} & \text { Se } \quad 50<x<250 \\
1 & \text { Se } x>250
\end{array}\right.
$$

Onde $x$ é o valor da concentração de As em ppm e $\mu(x)$ é a função de associação difusa (fuzzy). Cada valor de $x$ é associado com um valor de $\mu(x)$, e os pares ordenados $[x, \mu(x)]$ são conhecidos coletivamente como um conjunto difuso (fuzzy set).

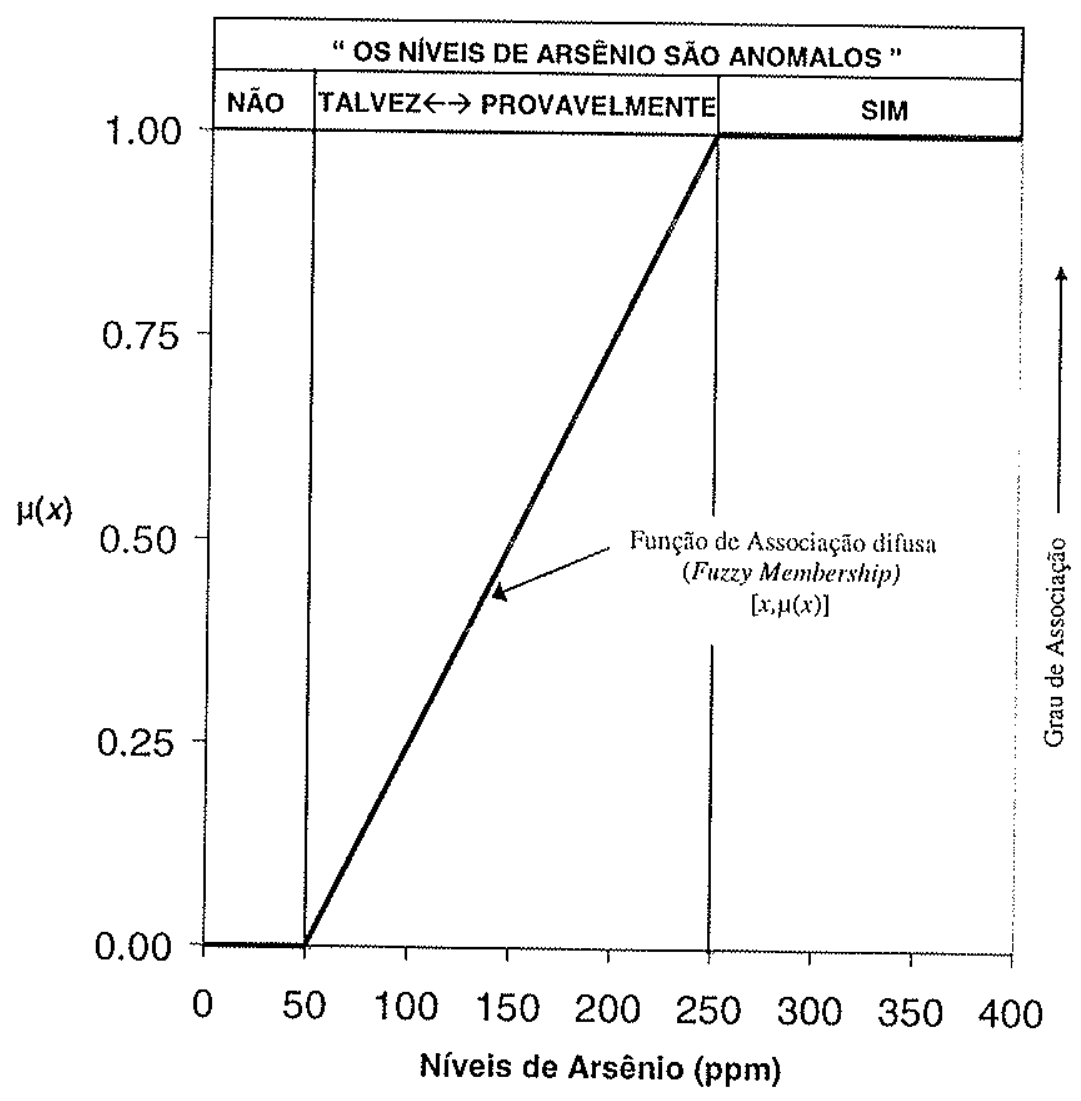

Figura 6.4 - Gráfico mostrando a função de associação difusa (fuzzy) parter (1996). conjunto de observações para os quais "os niveis de arsênio são anomalos".

A forma da função não é necessariamente linear, como apresentado na equação 6-3 e na Figura 6.4, podendo tomar uma forma analítica ou arbitrária mais apropriada ao problema em análise. No caso da análise de dados de declividade a função mais adequada a ser utilizada é a do tipo sigmoidal, como apresentado na Figura 6.5, que classifica os dados no conjunto difuso utilizando-se dois parâmetros $\alpha(0.04)$ e $\beta(50)$ na função $f(z)=1 /[1+\alpha(z-\beta) 2]$, representando os limiares que classificam a declividade em efetivamente baixa e alta, respectivamente. 


$$
f(z)=\left\{\begin{array}{lll}
0 & \text { se } z<0.04 \\
\frac{1}{\left[1+0.025(z-50)^{2}\right]} & \text { se } 0.04<z<50 \\
1 & \text { se } z>50
\end{array}\right.
$$

Onde z é o valor da declividade em graus e $f(x)$ é a função de associaçäo difusa (fuzzy).

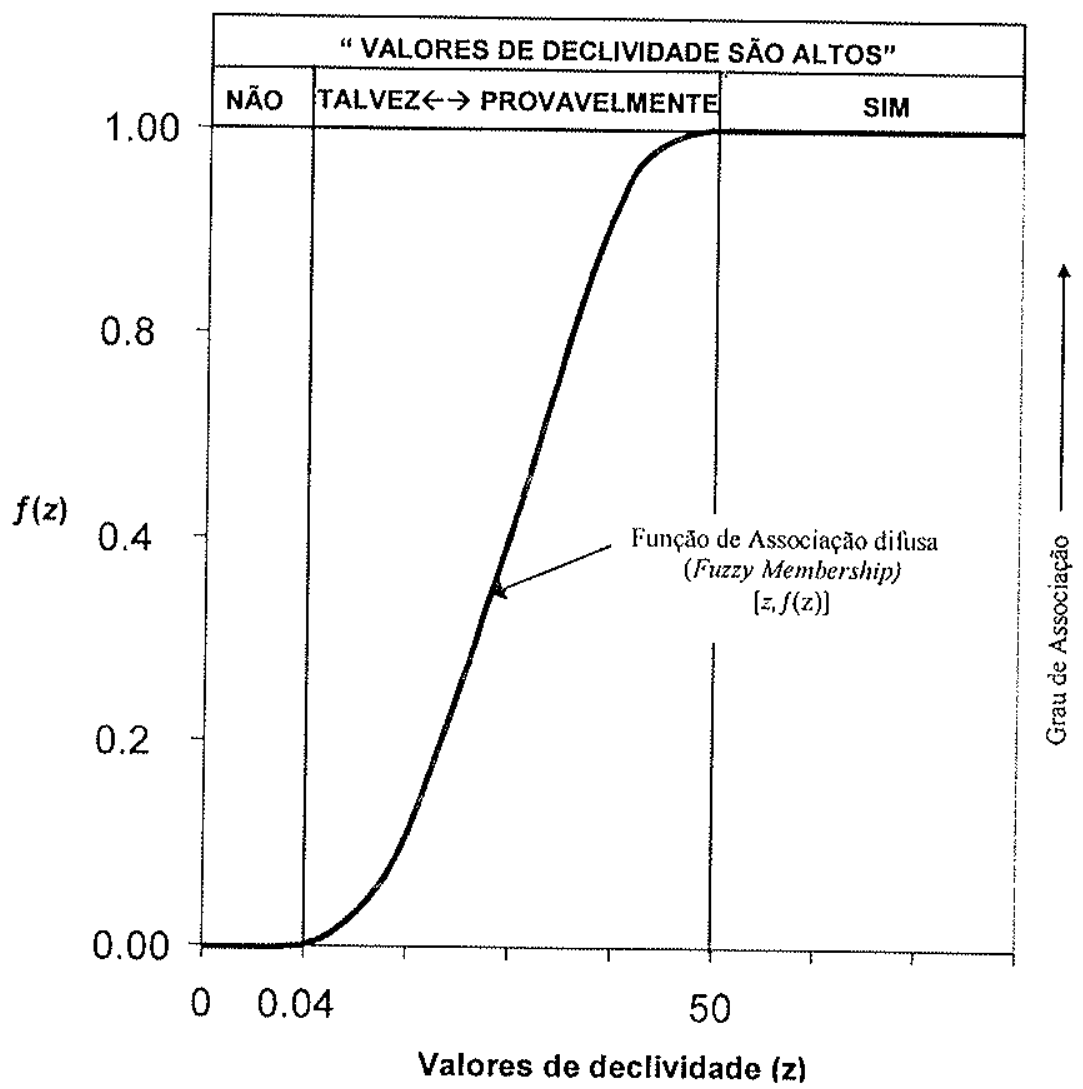

Fonte: Bonham-Carter (1996).

Figura 6.5 - Gráfico mostrando a função de associação difusa (fuzzy) para um conjunto de observações para os quais "os valores de declividade são altos".

\subsubsection{Processo analítico hierárquico (AHP-Analytical Hierarchy Process)}

Durante o processo de análise muitas vezes surge a necessidade de se definir quais fatores empregados são mais importantes, ou seja, em uma combinação de dados para suporte à decisão qual será a contribuição relativa de cada fator?

A técnica AHP (Analytical Hierarchy Process), proposta por Saaty (1987), permite a estimativa da importância relativa de cada um dos fatores envolvidos, baseando-se na lógica da comparação pareada. 
O programa IDRISI apresenta um módulo de apoio para a atribuição de pesos para um conjunto de fatores envolvidos em uma análise multi-critério seguindo a mesma técnica de comparação pareada de Saaty (1987). As relações são feitas utilizando-se uma escala continua de 9 pontos como mostrado nas Tabela 6.4 e 6.5 .

Tabela 6.4 -Escala de importância relativa empregada na análise pareada dos fatores na técnica AHP.

\begin{tabular}{|c|c|c|}
\hline Intensidade & Importância & Explicação sobre os fatores \\
\hline 1 & Igual & Contribuem igualmente para o objetivo \\
\hline 2 & Igual / Moderada & \\
\hline 3 & Moderada & $\begin{array}{l}\text { Um fator é ligeiramente mais importante do que o } \\
\text { outro }\end{array}$ \\
\hline 4 & Moderada / Essencial & \\
\hline 5 & Essencial & $\begin{array}{l}\text { Um fator é claramente mais importante do que o } \\
\text { outro }\end{array}$ \\
\hline 6 & Essencial / Demostrada & \\
\hline 7 & Demonstrada & $\begin{array}{l}\text { Um fator é fortemente favorecido e sua maior } \\
\text { relevância foi demonstrada na prática }\end{array}$ \\
\hline 8 & Demonstrada / Extrema & \\
\hline 9 & Extrema & $\begin{array}{l}\text { A evidência que diferencia os fatores é da maior } \\
\text { ordem possivel }\end{array}$ \\
\hline
\end{tabular}

Fonte: Eastman (1997).

Tabela 6.5 - Escala contínua utilizada no programa IDRISI para comparação relativa entre fatores envolvidos na determinação de pesos para ponderação em uma análise multi-critério.

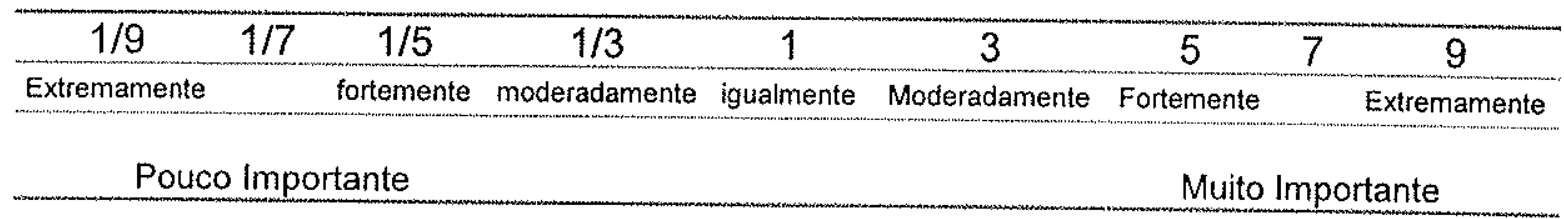

Eastman (1997) apresenta um exemplo de análise multi-critérios utilizando a técnica AHP para a ponderação de pesos na análise para locação de um distrito industrial. A Tabela 6.6 apresenta a matriz de comparação pareada, que é simétrica, sendo preenchida somente a metade triangular inferior. As células restantes constituem o par recíproco (por exemplo, o fator de declividade é moderadamente/fortemente - 4 mais importante do que o fator proximidade do centro urbano, ou seja o fator proximidade ao centro urbano é moderadamente/fortemente - $1 / 4$ - menos importante do que o fator declividade). 
Tabela 6.6 - Exemplo de matriz de comparação pareada para análise da importância relativa de 5 fatores na análise para desenvolvimento de distritos industriais.

\begin{tabular}{|c|c|c|c|c|c|}
\hline & $\begin{array}{c}\text { Proximidade } \\
\text { Estradas }\end{array}$ & $\begin{array}{c}\text { Proximidade } \\
\text { Centro Urbano }\end{array}$ & Declividade & $\begin{array}{c}\text { Pequenos } \\
\text { Núcleos de } \\
\text { ocupação }\end{array}$ & $\begin{array}{c}\text { Distância } \\
\text { De Parques }\end{array}$ \\
\hline $\begin{array}{c}\text { Proximidade } \\
\text { Estradas }\end{array}$ & 1 & 1 & & & \\
\hline $\begin{array}{c}\text { Proximidade } \\
\text { Centro Urbano }\end{array}$ & $1 / 3$ & 4 & 1 & & \\
\hline Declividade & 1 & 2 & $1 / 7$ & 1 & 1 \\
\hline $\begin{array}{c}\text { Pequenos } \\
\text { Núcleos } \\
\text { De ocupação }\end{array}$ & $1 / 7$ & 2 & $1 / 2$ & 4 & Fonte: Eastman (1997) \\
\hline $\begin{array}{c}\text { Distância } \\
\text { de Parques }\end{array}$ & $1 / 2$ & & & &
\end{tabular}

O cálculo dos pesos é feito então utilizando-se o auto-vetor principal da matriz pareada. Segundo Eastman (1997) uma boa aproximação para o resultado pode ser obtida calculando-se os pesos em cada coluna e fazendo-se a média com todas as colunas. Utilizando somente a primeira coluna a soma dos pesos é 2.98. Dividindo-se cada entrada da primeira coluna por 2.98 resultam os pesos de $0.34,0.11,0.34,0.05$, e 0.17 . O resultado dos pesos com o cálculo do auto-vetor principal é apresentado na Tabela 6.7.

Os pesos obtidos podem ser aceitos caso a razão de consistência seja menor do que 0.10 , caso contrário recomenda-se refazer a análise pareada. $O$ valor da razão de consistência indica a probabilidade dos pesos terem sido gerados aleatoriamente.

Tabela 6.7 - Pesos derivados do cálculo do auto-vetor principal da matriz de comparação pareada. A razão de consistência indica a probabilidade da pontuação ter sido obtida ao acaso.

\begin{tabular}{|c|c|}
\hline FATOR & PESO \\
\hline Proximidade de estradas & 0.33 \\
\hline Proximidade ao centro Urbano & 0.08 \\
\hline Declividade & 0.34 \\
\hline Pequenos núcleos de ocupação & 0.07 \\
\hline Distância de parques & 0.18 \\
\hline
\end{tabular}




\subsection{Sensoriamento remoto}

Lillesand e Kiefer (1994) definem o sensoriamento remoto como a ciência e arte de obter informações sobre um objeto, área ou fenômeno, analisando-se dados adquiridos por um instrumento que não está em contato com o objeto, área ou fenômeno sob investigação.

Os instrumentos utilizados geralmente apresentam um conjunto de sensores sensiveis a determinada porção do espectro eletromagnético. Os olhos humanos, por exemplo, realizam sensoriamento remoto na faixa que vai do azul ao vermelho (comprimento de onda: 0,4-0,7 $\mu \mathrm{m}$ ), referida como faixa do visivel.

Diferentes sensores estão disponíveis em satélites ou plataformas aéreo portadas, muitos utilizam a faixa que vai de 0,3 até $14 \mu \mathrm{m}$, que corresponde ao espectro óptico ${ }^{6}$, incluindo o UV, visivel, infravermelho próximo, médio e termal. Os satélites dessa categoria mais conhecidos são os da série Landsat e SPOT, sendo abordados neste trabalho os satélites Landsat-5 e 7.

Os satélites Landsat 5 e 7 apresentam os sensores TM e ETM, respectivamente. O satélite Landsat 5 foi lançado em 01/03/1984 transportando dois sensores, o MSS (Multispectral Scanner System) e o TM (Thematic Mapper). O Landsat 7 foi lançado em 15/04/1999 transportando o sensor ETM+ (Enhanced Thematic Mapper). A Tabela 6.8 compara as principais características de cada sensor.

Ambos satélites estão atualmente em operação (abril/2002), sendo que a qualidade dos dados do Landsat 5 tem decaído ao longo dos últimos anos, visto que está muitos anos além da vida útil prevista. Ambos sistemas realizam a bordo a conversão do sinal analógico para digital utilizando o limite de quantificação de 256 valores ( 8 bits).

As principais modificações do ETM+ incluem melhorias na resolução espacial da banda termal (B6), adição da banda pancromática (B8) e melhorias no processo de calibração radiométrica a bordo.

\footnotetext{
${ }^{6}$ O termo espectro óptico é utilizado em referência às lentes e espelhos, muitas vezes presentes nos sensores, que são utilizadas para refratar e refletir a energia eletromagnética desta faixa (Lillesand \& Kiefer, 1994).
} 
Tabela 6.8 - Comparação entre as larguras das bandas espectrais e resolução espacial dos sensores TM e ETM+.

\begin{tabular}{|c|c|c|c|c|c|c|c|c|}
\hline Sensor & Banda 1 & Banda 2 & Banda 3 & Banda 4 & Banda 5 & Banda 6 & Banda 7 & Banda 8 \\
\hline TM & $0,45-0,52$ & $0,52-0,60$ & $0,63 m-6,69$ & $0,76-0,90$ & $1,55-1,75$ & $10,4 \sim 12,5$ & $2,08-2,35$ & N/A \\
\hline Resolução & 30 & 30 & 30 & 30 & 30 & 120 & 30 & \\
\hline ETM+ & $0,45-0,52$ & $0,53-0,61$ & $0,63-0,69$ & $0,78-0,90$ & $1,55-1,75$ & $10,4-12,5$ & $2,09 m-2,35$ & $0,52-0,90$ \\
\hline Resolução & 30 & 30 & 30 & 30 & 30 & 60 & 30 & 15 \\
\hline
\end{tabular}

O processamento das imagens de sensoriamento remoto pode ser dividido em duas etapas: pré-processamento e processamento digital.

\subsubsection{Pré-processamento}

A etapa de pré-processamento visa o tratamento dos dados originais fornecidos, geralmente obtidos com nível de correção básico, o que corresponde às calibraçōes e correções durante o processo de geração da imagem. Os procedimentos de préprocessamento são divididos em correção radiométrica, incluindo a correção atmosférica e correção geométrica.

\subsubsection{Correção Radiométrica}

A correção radiométrica pode ser dividida em três tipos:

- Normalização dos ângulos solares;

- Correção da variação de distância Sol-Terra;

- Efeito atmosférico;

Eastman (1997) ressalta que ocorrem modificações nos padrões de reflectância conforme a data de aquisição. Descreve que o estudo de padrões de reflectância em diferentes datas, ou ao longo de mosaicos de imagens, deve ser precedido de uma calibração dos valores de radiância, de forma que os niveis de reflectância absolutos dos objetos medidos por diferentes sensores correspondam entre imagens separadas. Pode ainda ser necessária a normalização dos ângulos solares e a correção devido a variação da distância Terra-Sol.

Lillesand e Kiefer (1994), descrevem que, no caso do sensoriamento remoto óptico (visível e infravermelho próximo), é comum a geraçäo de mosaicos de imagens tomadas em diferentes datas, ou o estudo de modificações nas características de reflectância de alvos na superficie em diferentes datas e localizações. Em tais aplicações é necessário o emprego do modelo de correção de elevação solar e de correção dos efeitos de variação da distância Terra-Sol.

A correção da elevação solar leva em consideração a posição solar em relação à Terra conforme a estação do ano (Figura 6.6). 


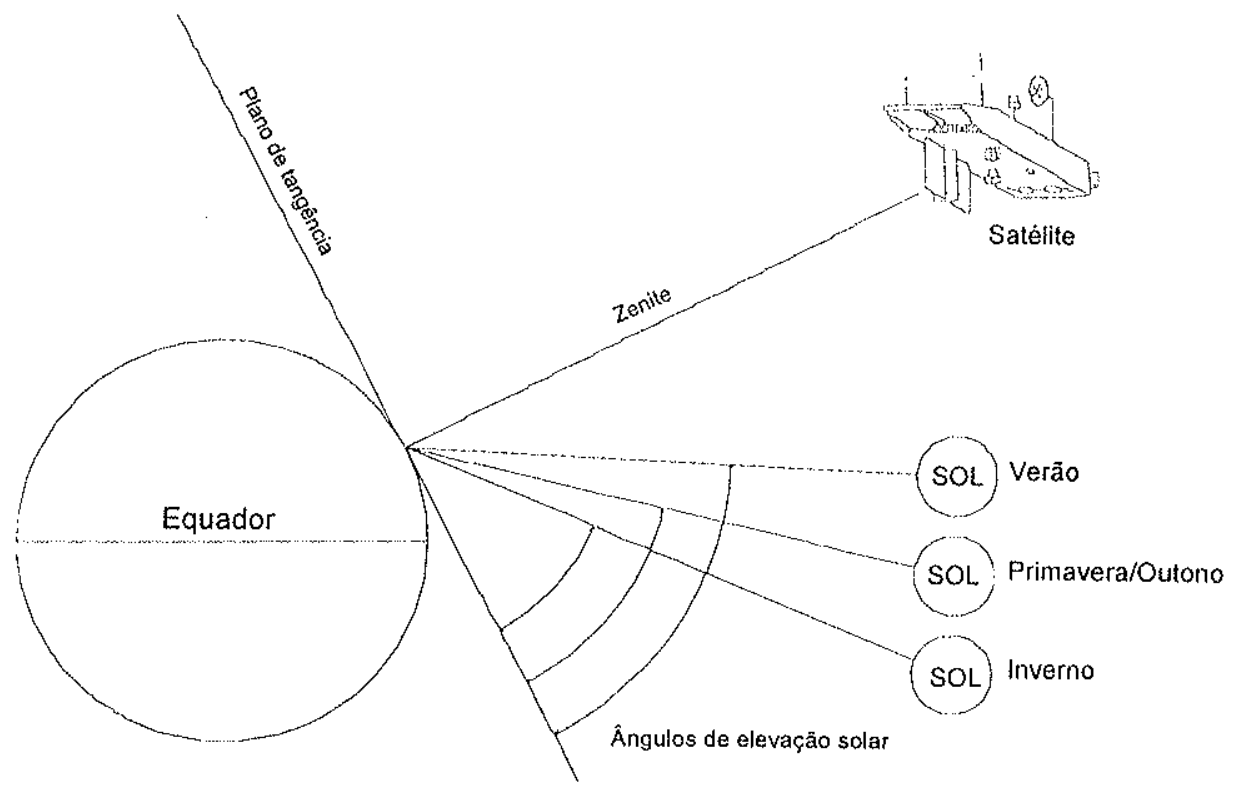

Lillesand e Kiefer (1994)

Figura 6.6 - Efeitos da mudança de estação nos ângulos de elevação solar (o ângulo zênite solar $=90^{\circ}$ menos o ângulo de elevação solar).

Através desse processo de padronização, os dados de imagens adquiridas sob diferentes ângulos de iluminação solar são normalizados pelo cálculo da intensidade (brightness) dos valores dos pixels, considerando a posição do Sol no zênite, em cada data de passagem. Em qualquer método aplicado (divisão do valor do $D N$ pelo seno do ângulo de elevação solar naquela data e localização geográfica da imagem; ou cada $D N$ é dividido pelo coseno do ângulo solar a partir do zênite, resultando na mesma correção) os efeitos topográficos e atmosféricos são ignorados.

A correção da distância Sol-Terra é aplicada para normalizar as diferenças causadas pelas mudanças na distância entre a Terra e o Sol para cada estação, determinando uma modificação na irradiação do Sol, que diminui proporcionalmente ao quadrado da distância entre a Terra e o Sol.

Ignorando os efeitos atmosféricos, a combinação da influência do ângulo de zenite solar e a distância Terra-Sol na irradiação incidente na superfície da Terra, pode ser expressa como:

$$
E=\frac{E o \cdot \cos \Theta}{d^{2}}
$$

onde:

$E=$ irradiação solar normalizada

Eo= irradiação solar na distância Terra-Sol

$\Theta=$ =ângulo solar a partir do zenite

$d=$ distância Terra-Sol, em unidades astronômicas $\left(149.6 \times 10^{6} \mathrm{~km}\right)$ 


\subsubsection{Correção atmosférica}

Segundo Lillesand e Kiefer (1994), a influência atmosférica na resposta espectral (padrão) afeta a radiância registrada pelo sensor para um dado ponto da superfície terrestre de duas maneiras quase contraditórias:

- reduz (atenua) a energia que atinge um determinado objeto na superfície (e a energia que é refletida do objeto);

- atua como um alvo refletor, ou seja, ela adiciona um espalhamento, adicionando radiância externa ao sinal detectado pelo sensor (path radiance).

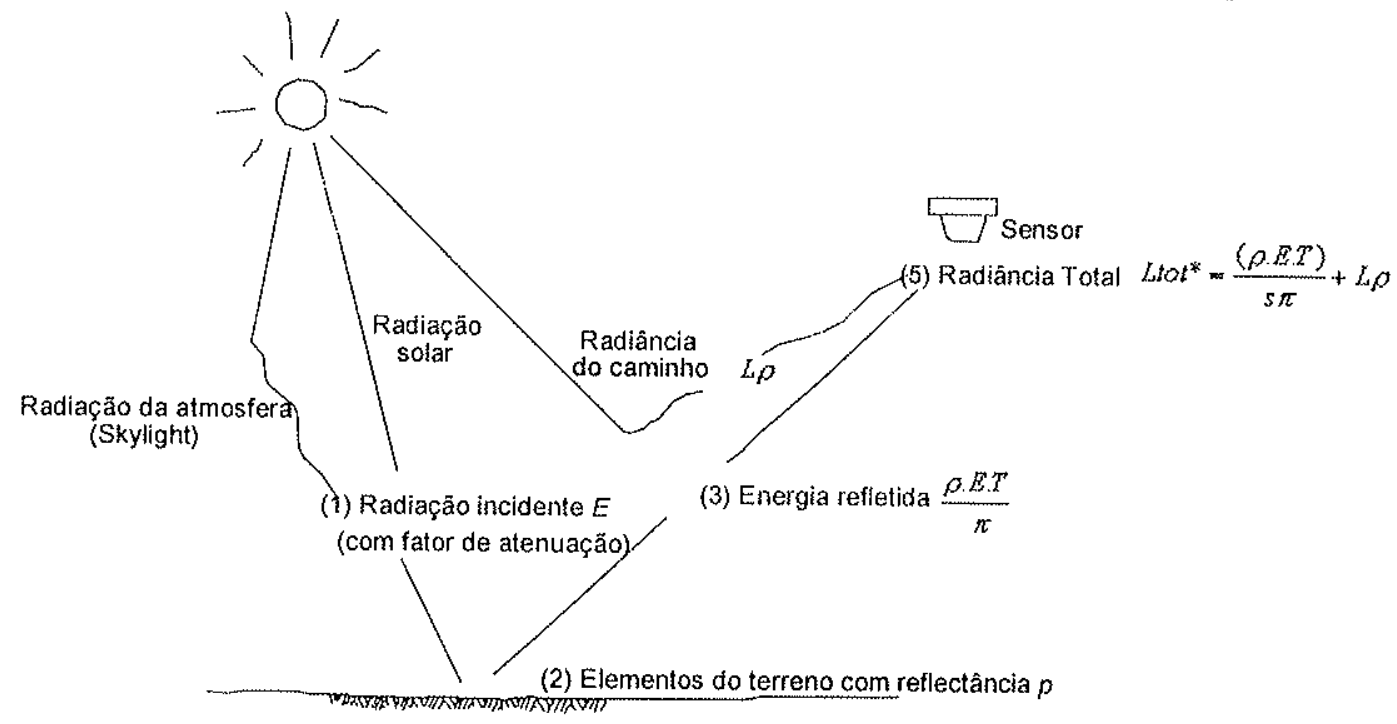

Lillesand e Kiefer (1994)

Figura 6.7 - Esquema mostrando o caminho da radiação eletromagnética (REM) e suas interações até sua captação pelo sensor.

No esquema apresentado, na Figura 6.7, pode-se observar a influência dos efeitos atmosféricos na medida da energia solar refletida. A radiação solar (sunlight) e a radiação do céu (skylight) ( $E$ ) atenuadas, são refletidas pelo alvo no terreno ( $\rho E T / s \pi$ ) e combinadas com a radiância do caminho (path radiance) $(L p)$, constituem a radiância total (Ltot) armazenada pelo sensor.

Expressando-se essas relações matematicamente, o total de radiância registrado pelo sensor pode ser relacionado à reflectância da superficie (alvo) e à radiação recebida, ou irradiância, utilizando-se da equação:

$$
L t o t^{*}=\frac{(\rho \cdot E \cdot T)}{s \pi}+L \rho
$$

Onde:

Ltot $^{*}=$ radiância espectral total medida pelo sensor;

$\rho=$ reflectância do objeto

$E=$ irradiância sobre o objeto, energia recebida;

$T=$ transmissão da atmosfera;

$L \rho=$ radiância do caminho, originada na atmosfera e não no objeto;

* Todas as quantidades de energia medidas dependem do comprimento de onda. 
Somente o primeiro termo da equação contém informação válida sobre a reflectância da superfície. O segundo termo representa o espalhamento do "caminho da radiância" (path radiance), que introduz "névoa" na imagem e reduz o contraste (lembrando que o espalhamento é dependente do comprimento de onda: quanto menor o comprimento de onda geralmente maior será o efeito de espalhamento).

Os procedimentos para compensação desse efeito são aplicados para minimizar sua influência. Uma maneira de compensar esse efeito nos dados multi-espectrais é observar a radiância registrada sobre áreas alvo com reflectância próxima de zero. Por exemplo, a reflectância de um corpo d'água profundo é essencialmente zero na região do infravermelho do espectro. Por essa razão, qualquer sinal observado sobre tal área representa a influência do caminho (atmosfera), e esse valor pode ser subtraído de todos os pixels naquela banda. Por conveniência esse tipo de correção (haze correction) é freqüentemente aplicada uniformemente pela cena, o que pode ou não ser válido, dependendo da uniformidade da atmosfera sobre a cena.

Lillesand e Kiefer (1994) ainda destacam outro processamento de correção radiométrica, empregado em aplicações quantitativas de imagens digitais que é a conversão de DNs para valores de radiância absoluta, empregado na comparação de medidas feitas por diferentes sensores como o MSS no Landsat-3 e Landsat-5.

Eastman (1997) também descreve a equação de calibração dos valores medidos pelo sensor para radiância, citando o módulo RADIANCE do IDR/S/ V.2, que converte os valores normalizados dos DNs para valores de radiância calibrados, usando dados do sensor. No caso do programa IDR/SI V.2 os valores utilizados e cálculos efetuados baseiam-se na publicação da EOSAT: "Landsat Technical Notes n¹,August 1986". A data de validade dos parâmetros é apresentada na Tabela 6.9.

Os valores reais de radiância são padronizados para o limite 0-255, baseando-se nos valores mínimos (Lmin.) e máximos (Lmáx.) de radiância encontrados em cada banda. Os valores mínimos e máximos para os dados de radiância do TM-Landsat 5 seguem os limites apresentados na Tabela 6.10.

Tabela 6.9 - Fontes utilizadas para definição dos parâmetros de calibração radiométrica do Sensor TM-Landsat, utilizados pelo programa IDRISI V.2.0.

\begin{tabular}{ccc}
\hline Fonte & Data de validade & Sensor \\
\hline Scrounge-ERA & Anterior gosto/1983 & TM - Landsat $4 / 5$ \\
TIPS-ERA & Anterior 15/Janeiro/1984 & TM - Landsat $4 / 5$ \\
TIPS-ERA & Após $15 /$ Janeiro/1984 e anterior & TM - Landsat $4 / 5$ \\
\hline
\end{tabular}


Tabela 6.10 - Dados de radiância utilizados para o cálculo do Gain e Offset das imagens, segundo a data de aquisição das imagens, para cada fonte citada na Tabela 6.7 .

\begin{tabular}{|c|c|c|c|c|c|c||}
\hline $\begin{array}{c}\text { Bandas do } \\
\text { Landsat TM }\end{array}$ & \multicolumn{2}{|c|}{$\begin{array}{c}\text { Antes de } \\
\text { Ago. 1983 } \\
\text { (Scrounge-ERA) }\end{array}$} & \multicolumn{2}{c|}{$\begin{array}{c}\text { Antes de } \\
15 \text { Jan. 1984 } \\
\text { (TIPS-ERA) }\end{array}$} & \multicolumn{2}{c|}{$\begin{array}{c}\text { Depois de } \\
\text { 15 Jan. 1984 e } \\
\text { Depois 1 Oct. 1991 } \\
\text { (TIPS-ERA) }\end{array}$} \\
\hline & Lmin $^{*}$ & Lmax & Lmin $^{*}$ & Lmax $^{*}$ & Lmin $^{*}$ & Lmax \\
\hline TM1 & $-0,152$ & 15,842 & 0,000 & 14,286 & $-0,1500$ & 15,21 \\
\hline TM2 & $-0,284$ & 30,817 & 0,000 & 29,125 & $-0,2800$ & 29,68 \\
\hline TM3 & $-0,117$ & 23,463 & 0,000 & 22,500 & $-0,1200$ & 20,43 \\
\hline TM4 & $-0,151$ & 22,432 & 0,000 & 21,429 & $-0,1500$ & 20,62 \\
\hline TM5 & $-0,037$ & 3,242 & 0,000 & 3,000 & $-0,0370$ & 2,719 \\
\hline TM6 & 0,200 & 1,564 & 0,484 & 1,240 & $-0,1238$ & 1,560 \\
\hline TM7 & $-0,015$ & 1,700 & 0,000 & 1,593 & $-0,0150$ & 1,438 \\
\hline
\end{tabular}

Fonte: htip:/ledcdaac.usgs.gov/pathfinder fag htmlitradiance * Lmin e Lmax estão em unidade de radiância, miliwatts por centímetro quadrado por steradiano por micrômetro $\left(\mathrm{mW} / \mathrm{cm}^{2} / \mathrm{sr} /\right.$ micrometer $)$.

A fórmula para converter os números digitais $(D N s)$ para radiância é:

$$
L=\operatorname{gain} \cdot D N+o f f s e t
$$

Segundo a descrição que acompanha os dados da EOSAT, para o cálculo do gain e offset, para imagens tomadas antes de 01 de Outubro de 1991, deve-se aplicar a seguinte fórmula:

$$
\text { Gain }=\frac{(L \max -L \min )}{255}
$$

\section{Offset $=L \min$}

Para calcular o gain e offset, para imagens tomadas após 01 de Outubro de1991, deve-se empregar a seguinte fórmula:

$$
\text { Gain }=\frac{(L \max )}{254}-\frac{(L \min )}{255}
$$

Offset $=L \mathrm{~min}$

A Tabela 6.11 apresenta o resultado dos cálculos de "gain" e "offset" utilizandose os dados fornecidos na Tabela 6.8, e as fórmulas específicas para cada período de validade dos dados. 
Tabela 6.11 - Dados de radiância utilizados para o cálculo do Gain e Offset das imagens, segundo a data de aquisição das imagens, para cada fonte citada na Tabela 6.10 .

\begin{tabular}{|c|c|c|c|c|c|c|c|c|}
\hline & \multicolumn{2}{|c|}{$\begin{array}{c}\text { (I) } \\
\text { Antes de } \\
\text { Agosto de 1983 } \\
\text { (Scrounge-ERA) }\end{array}$} & $\begin{array}{c}\text { (II) } \\
\text { Após } \\
15 \text { de Janeiro } \\
1984 \\
\text { (TIPS**-ERA) }\end{array}$ & $\begin{array}{c}\text { Após 15 de Jan. } \\
1984 \text { e Antes de } \\
1^{\circ} \text { Outubro 1991 } \\
\text { (TIPS-ERA) }\end{array}$ & $\begin{array}{c}\text { (II) } \\
\text { (IV) } \\
\text { Após } \\
\text { Outubro 1991 } \\
\text { (TIPS-ERA) }\end{array}$ \\
\hline Bandas & Gain & Offset & Gain & Offset & Gain & Offset & Gain & Offset \\
\hline TM1 & 0,0627 & $-0,1520$ & 0,0560 & 0,0000 & 0,0602 & $-0,1500$ & 0,0630 & $-0,1520$ \\
\hline TM2 & 0,1220 & $-0,2840$ & 0,1142 & 0,0000 & 0,1175 & $-0,2800$ & 0,1224 & $-0,2840$ \\
\hline TM3 & 0,0925 & $-0,1170$ & 0,0882 & 0,0000 & 0,0806 & $-0,1200$ & 0,0928 & $-0,1170$ \\
\hline TM4 & 0,0886 & $-0,1510$ & 0,0840 & 0,0000 & 0,0815 & $-0,1500$ & 0,0889 & $-0,1510$ \\
\hline TM5 & 0,0129 & $-0,0370$ & 0,0118 & 0,0000 & 0,0108 & $-0,0370$ & 0,0129 & $-0,0370$ \\
\hline TM6 & 0,0053 & 0,2000 & 0,0030 & 0,4840 & 0,0066 & $-0,1238$ & 0,0054 & 0,2000 \\
\hline TM7 & 0,0067 & $-0,0150$ & 0,0062 & 0,0000 & 0,0057 & $-0,0150$ & 0,0068 & $-0,0150$ \\
\hline
\end{tabular}

* Gain e offset estão em unidade de radiância, miliwatts por centimetro quadrado por steradiano por micrômetro $\left(\mathrm{mW} / \mathrm{cm}^{2} / \mathrm{sr} / \mu \mathrm{m}\right)$.

** TIPS - Thematic Mapper Image Processing System.

As imagens fornecidas pelo INPE apresentam em seus arquivos descritores as informações sobre gain e offset, aplicados em cada banda no cálculo dos DNs. A Tabela 6.12 apresenta os dados obtidos nas imagens fornecidas pelo INPE.

Os valores utilizados para a calibração radiométrica das imagens, apresentados nas Tabela 6.12 e 6.13 , são semelhantes aos dados apresentados no TIPS-ERA (III). A EOSAT indica a utilização dos mesmos dados da Tabela 6.11 para a conversão utilizando, contudo, para imagens após 01 de Outubro de 1991, a fórmula 6-10 no cálculo dos valores dos DNs (http:/ledcdaac.usgs. gov/ pathfinder faq.html \#radiance). Os resultados dos cálculos de gain e offset para imagens adquiridas após 01 de Outubro de 1991, são apresentados na Tabela 6.11 .

A comparação entre as informações contidas nos arquivos descritores de três imagens do TM-Landsat 5, de áreas geográficas e datas distintas, apresentadas na Tabela 6.10, indica que os dados apresentam inconsistência nas informações fornecidas, por serem idênticos nas três datas. A utilização destas informações pode levar a erros nos resultados do processo de conversão de valores de DNs para radiância.

A documentação dos arquivos que acompanha as imagens descreve que as correções radiométricas foram executadas utilizando-se dados de calibração interna. Segundo o centro de atendimento aos usuários (ATUS-INPE, 2000), os parâmetros utilizados para a calibração das imagens são sempre os mesmos, não mudam 
conforme a área ou data de aquisição. A Tabela 6.13 apresenta os valores utilizados para a calibração dos dados em imagens completas processadas pelo INPE.

Tabela 6.12 - Valores de gain e offset contidos nos arquivos descritores das imagens no formato INPE*, para cada imagem adquirida.

\begin{tabular}{|c|c|c|c|c|c|c|}
\hline Datas & \multicolumn{2}{|c|}{$14 / 09 / 86$} & \multicolumn{2}{c|}{$09 / 09 / 90$} & \multicolumn{2}{|c|}{$18 / 07 / 94$} \\
\hline Bandas & gain & offset & gain & offset & gain & offset \\
\hline TM3 & 0,08059 & $-0,12000$ & 0,08059 & $-0,12000$ & 0,08059 & $-0,12000$ \\
\hline TM4 & 0,08150 & $-0,15000$ & 0,08150 & $-0,15000$ & 0,08150 & $-0,15000$ \\
\hline TM5 & 0,01080 & $-0,03700$ & 0,01080 & $-0,03700$ & 0,01080 & $-0,03700$ \\
\hline
\end{tabular}

Valores obtidos pela leitura do arquivo Lead.dat, fornecido juntamente com as imagens no formato INPE. Gain e offset estão em unidade de radiância, miliwatts por centimetro quadrado por steradiano por micrômetro $\left(\mathrm{mW} / \mathrm{cm}^{2} / \mathrm{sr} / \mu \mathrm{m}\right)$.

Tabela 6.13 - Valores de gain e offset contidos nos arquivos descritores das imagens fornecidas pelo INPE.

\begin{tabular}{|c|c|c|}
\hline Bandas & Offset & Gain \\
\hline TM1 & $-0,1500$ & 0,0602353 \\
\hline TM 2 & $-0,2800$ & 0,1174902 \\
\hline TM 3 & $-0,1200$ & 0,0805882 \\
\hline TM 4 & $-0,1500$ & 0,0814510 \\
\hline TM 5 & $-0,0370$ & 0,0108078 \\
\hline TM 6 & $-0,1238$ & 0,0066000 \\
\hline TM 7 & $-0,0150$ & 0,0056980 \\
\hline
\end{tabular}

*Valores obtidos pela leitura do arquivo Lead.dat, fornecido juntamente com as imagens no formato INPE. Gain e offset estão em unidade de radiância, miliwatts por centímetro quadrado por steradiano por micrômetro $(\mathrm{mW} / \mathrm{cm} 2 / \mathrm{sr} / \mu \mathrm{m})$.

A definição dos valores de calibração dos detectores de cada banda são importantes para a devida correção atmosférica da imagem, segundo a técnica descrita por Chavez $(1988,1989)$. Chavez (1988) descreve uma técnica melhorada de correção atmosférica baseada em uma técnica anterior de subtração do pixel escuro (simple dark-object subtraction technique), que também utiliza somente os dados contidos na imagem.

Essa técnica assume que é alta a probabilidade de existir pelo menos alguns pixels totalmente escuros, com $0 \%$ de reflectância, na imagem do Landsat, pois ela chega a conter mais de 45 milhões de pixels. As regiões com reflectância nula deveriam estar associadas às áreas sombreadas devido à topografia ou nuvens, pois idealmente o sistema imageador não deveria detectar nenhuma reflectância nos locais de ocorrência de sombras, atribuindo o valor 0 aos DNs nessas áreas.

Devido aos efeitos causados pelo espalhamento atmosférico essas áreas sombreadas não serão completamente escuras, estando presente também espalhamento secundário resultante da própria atmosfera (skylight), que não é 
considerado nessa simplificação. Portanto, devido ao espalhamento atmosférico, os detectores de cada banda armazenam valores de reflectância maiores do que zero para as áreas supostamente sombreadas, que não deveriam conter qualquer informação.

Esses valores devem então ser subtraídos de cada banda espectral para a remoção do componente de espalhamento de primeira ordem presente. Muitos métodos podem ser utilizados para a extração desses valores de DN a partir dos dados digitais. O método do histograma permite que o usuário selecione o valor a ser subtraído diretamente do histograma de freqüências de DNs da imagem, que dependerá da forma de distribuição dos valores. Essa distribuição geralmente apresenta um intenso aumento dos valores de freqüência para cada incremento de $D N$, sendo escolhido como valor de corte o ponto em que ocorre essa transição.

Os histogramas das bandas espectrais, relativas ao visivel, apresentam claramente um deslocamento geral da distribuição de freqüências, para valores maiores de DNs. Esse deslocamento na distribuição de valores é conseqüência da maior influência atmosférica a que estão sujeitas as bandas espectrais relativas ao visível.

O método do histograma deve ser aplicado levando-se em consideração toda a imagem, ou uma grande parte, caso contrário os valores escolhidos podem não corresponder ao mínimo procurado, efetuando uma sobrecorreção na imagem (overcorrection).

O método melhorado, descrito por Chavez $(1988,1989)$, indica que caso sejam utilizados os valores determinados pela técnica padrão de remoção do pixel escuro (standard dark-object subtraction technique), poderão ocorrer problemas no estágio de análise dos dados, devido aos valores escolhidos para subtração não seguirem o modelo relativo de espalhamento. Essa não conformidade pode resultar na sobrecorreção em algumas ou todas bandas espectrais, e incoerência na relação espectral entre as bandas.

No método descrito (Chavez, 1988) deve-se utilizar inicialmente o método padrão de subtração do pixel escuro, por amostragem ou histograma, para a determinação dos valores a serem subtraidos em cada banda. Esses valores permitem uma avaliação das condições atmosféricas existentes na imagem, que podem variar de: muito limpa, limpa, moderadamente limpa, bruma leve ou bruma densa, correspondendo aos modelos relativos de espalhamento apresentados na Tabela 6.14. 

Tabela 6.14 - Condições atmosféricas e modelo relativo de espalhamento aplicado
para correção atmosférica.

\begin{tabular}{cc} 
Condiçóes atmosféricas & Modelo relativo \\
Muito limpa & de espalhamento \\
Limpa & $\lambda^{-4}$ \\
Moderamente limpa & $\lambda^{-2}$ \\
Bruma leve & $\lambda^{-1}$ \\
Bruma densa & $\lambda^{-0,7}$ \\
\hline
\end{tabular}

Fonte: Chavez (1988)

Os modelos relativos de espalhamento são baseados em dois conhecidos modelos de espalhamento: Rayleigh e Mie. O modelo de espalhamento Rayleigh determina que o espalhamento é inversamente proporcional à quarta potência do comprimento de onda $\left(\lambda^{-4}\right)$, o que determina que menores comprimentos de onda são espalhados muito mais do que os maiores comprimentos de onda. Esse espalhamento é principalmente causado por moléculas de gás, que são muito menores do que os comprimentos de onda da radiação eletromagnética incidente.

O espalhamento Mie determina que o espalhamento é inversamente proporcional ao comprimento de onda, e geralmente para uma atmosfera moderadamente limpa, o fator é $\lambda^{-1}$. Contudo, pode variar de $\lambda^{0}$ para $\lambda^{-4}$, com $\lambda^{0}$ representando espalhamento completo (p.e. cobertura completa de nuvens). O espalhamento Mie é causado por partículas que são aproximadamente do mesmo tamanho que os comprimentos de onda da radiação eletromagnética incidente, tais como particulas de poeira ou fumaça.

A escolha do modelo relativo de espalhamento baseia-se na observação dos valores obtidos pelo método de subtração do pixel escuro, ou histograma, e podem ser relacionados conforme a Tabela 6.15, que apresenta valores comumente encontrados para cada condição atmosférica. Segundo o modelo de espalhamento utilizado por Chavez (1988), esses limites permitem uma avaliação prévia da imagem quanto as condições atmosféricas, segundo os valores de subtração estimados.

Tabela 6.15 - Relação entre os valores médios obtidos na estimativa do pixel escuro para a banda TM1, e os modelos relativos de espalhamento (condiçōes atmosféricas).

$\begin{array}{cc}\text { Modelo relativo } & \\ \text { de espalhamento } & \text { Limite dos valores } \\ \text { (condicóes atmosféricas) } & =55 \\ \text { Muito limpa } & 56-75 \\ \text { Limpa } & 76-95 \\ \text { Moderamente limpa } & 96-115 \\ \text { Bruma leve } & >115 \\ \text { Bruma densa } & \end{array}$


A Tabela 6.16 apresenta a porcentagem de espalhamento que cada banda contribui para o espalhamento total, que ocorre em todas as bandas para cada modelo relativo de espalhamento. Nota-se que para modelos de espalhamento com maior influência atmosférica a relação de espalhamento torna-se mais similar entre as bandas, devido ao espalhamento não seletivo que passa a ocorrer de forma mais intensa.

O modelo relativo de espalhamento é utilizado para estimar os valores a serem corrigidos nas imagens, tomando-se como base uma das bandas espectrais da faixa do visível, que apresenta maior interferência atmosférica. A banda é escolhida pela análise dos histogramas ou valores amostrados, que geralmente apresentam um súbito incremento nos valores mais baixos dos DNs, resultado da interferência atmosférica

A análise do valor inicial de correção, escolhido segundo o método de histograma ou do pixel-escuro, permite a determinação do modelo de espalhamento que deve ser utilizado, conforme a Tabela 6.15, permitindo a definição dos valores de correção para as demais bandas, conforme a Tabela 6.17 , que apresenta os fatores de multiplicação para a predição dos valores de correção, dado o valor na banda TM 1 , para as demais bandas.

A escolha do valor inicial de correção atmosférica na banda 1 de $40(D N=40)$, por exemplo, resultaria em um ajuste nas bandas $2,3,4,5$ e 7 , para uma condição atmosférica muito limpa de: $22.5,11.7,4.7,0.3$, e 0.1 , respectivamente. Esses valores são o resultado da multiplicação do valor inicial determinado (40), pelos fatores de correção: $0.563,0.292,0.117,0.075$ e 0.002, para atmosfera muito limpa.

Tabela 6.16 - Relação entre os modelos relativos de espalhamento para cada banda espectral do satélite Landsat 5 , mostrando a participação de cada banda espectral no
espalhamento total, para cada

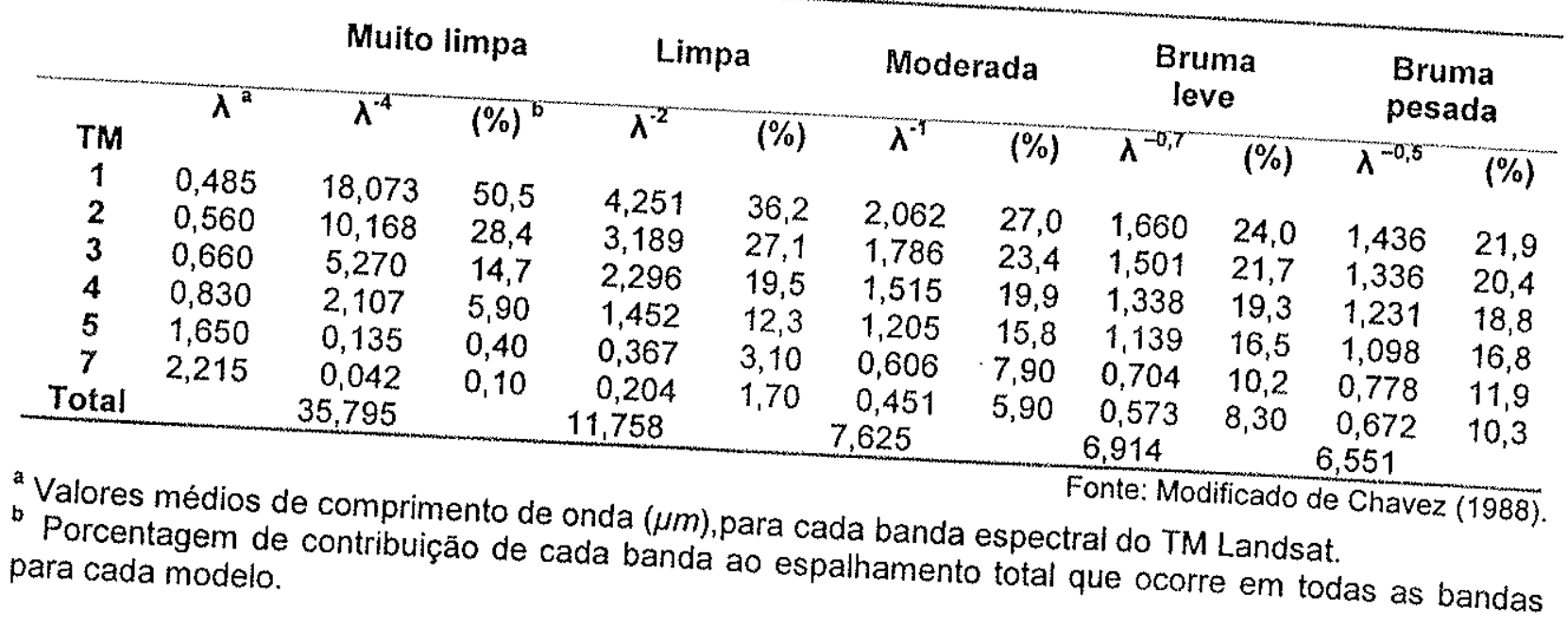


Esses valores, determinados pelo modelo de espalhamento relativo, não são os valores corretos de DNs para correção dos efeitos atmosféricos nos dados. Ainda é necessário ajustar as diferenças relativas ao gain e offset do sensor.

Tabela 6.17 - Fatores de multiplicação para a predição dos valores de correção a banda TM 1 .

\begin{tabular}{cccccc} 
& Muito limpa & Limpa & Moderada & $\begin{array}{c}\text { Bruma } \\
\text { leve }\end{array}$ & $\begin{array}{c}\text { Bruma } \\
\text { pesada }\end{array}$ \\
\hline$T M$ & $\lambda^{-4}$ (a) & $\lambda^{-2}$ & $\lambda^{-1}$ & $\lambda^{-0,7}$ & $\lambda^{-0,5}$ \\
1 & 1,000 & 1,000 & 1,000 & 1,000 & 1,000 \\
2 & 0,563 & 0,750 & 0,866 & 0,904 & 0,931 \\
3 & 0,292 & 0,540 & 0,735 & 0,806 & 0,857 \\
4 & 0,117 & 0,341 & 0,584 & 0,687 & 0,764 \\
5 & 0,007 & 0,086 & 0,294 & 0,424 & 0,542 \\
7 & 0,002 & 0,048 & 0,219 & 0,345 & 0,468 \\
\hline
\end{tabular}

(a) Fatores calculados utilizando a Tabela 6.16, onde para cada Fonte: Modificado de Chavez (1988). razão do comportamento de cada banda espectral pela banda modelo de espalhamento foi feita a P.e: Modelo de espalhamento "Muito limpa" TM $2=(10.168 / 18.073)=0.563$.

Segundo Chavez (1988) os valores de DNs armazenados pelo sensor podem ser representados pela seguinte equação:

onde,

$$
D N_{i}(X, Y)=\operatorname{Gain}_{i} *\left[\operatorname{Rad}_{i}(X, Y)\right]+\text { Offset }_{i}
$$

$D N_{i}(X, Y)=$ Número digital de saída para a banda $i$ para o pixel $(X, Y)$;

Gain $_{i}=$ fator de ganho utilizado para a banda $i$

$\operatorname{Rad}(X, Y)=$ valor de radiância no pixel $(X, Y)$ na banda $i$

Offset $i=$ fator de perda utilizado para a banda $i$

O valor de radiância (Rad i) é composto por termos multiplicativos e aditivos. Alguns dos principais componentes do termo multiplicativo incluem: a reflectância do pixel na coordenada $(X, Y)$ na banda $i[R i(X, Y)]$, as condições de declividade no pixel com coordenadas $(X, Y)$ [Slope $(X, Y)$ ], a elevação solar durante a coleta dos dados (Sun), e as características de absorção atmosférica na banda $i$ na data de armazenamento da imagem $(\tau i)$. O principal componente do termo aditivo é a interferência atmosférica presente na banda $i$ [Haze i]. Esses fatores podem ser utilizados para obter uma representação geral do parâmetro de radiância $[\operatorname{Rad} i(X, Y)]$ na equação (6-12), como segue:

$$
\operatorname{Rad}_{i}(X, Y)=\left[\operatorname{Ri}(X, Y) * \operatorname{Slope}(X, Y) * \operatorname{Sun} *\left(\tau_{i}\right)\right]+\text { Haze }_{i}
$$


Os fatores multiplicativos podem ser combinados em uma única variável chamada Mult $i(X, Y)$, e substituindo a equação (6-13) em (6-14), temos a seguinte relação:

$$
D N_{i}(X, Y)=\text { Gain }^{*}\left[\operatorname{Mult}_{i}(X, Y)+\text { Haze }_{i}\right]+\text { Offset } i
$$

$\mathrm{Na}$ equação (6-15) é possivel notar a importância da correção ou normalização para os parâmetros de gain e offset. Utilizando a equação $6-14$ e isolando o fator radiância temos:

$$
\operatorname{Rad}_{i}(X, Y)=\frac{D N_{i}(X, Y)-\text { Offset }_{i}}{\text { Gaini }_{i}}
$$

Essa relação pode ser utilizada para corrigir os dados segundo as variações de gain e offset. A equação permite a conversão dos valores de DNs para valores de radiância $\left(\mathrm{mWcm}^{-2} / \mathrm{sr}^{-1} / \mu \mathrm{m}^{-1}\right)$. Os valores de correção atmosférica pré determinados para cada banda espectral (DNs), podem ser devidamente ajustados para as variações de gain e offset, utilizando-se fatores de normalização para o gain, conforme a equação (6-16), que utiliza os valores da Tabela 6.18.

$$
D N\left(\text { Haze }_{i}\right)=\text { Norm }_{i} * \text { Haze }_{i}+\text { Offset }_{i}
$$

onde:

DN(Hazei) $=$ Número digital que representa o valor de correção atmosférica final para a banda $i$ Normi $=$ valor de ganho normalizado para a banda $i$

Hazej= valor de correçăo atmosférica determinado para a banda $i$ usando um modelo relativo de
espalhamento Offset $i=$ fator de offset utilizado para a banda $i$ Tabela 6.18 - Valores de Ganho e Offset para as bandas espectrais do Landsat 5 , e
normalização do fator de ganho (Norm $i$ ).

\begin{tabular}{cccc} 
TM & Ganho* $^{*}$ & Offset & Normalização (Gain) \\
1 & $-15,000$ & 6,024 & TM1 \\
2 & $-28,000$ & 11,749 & 1,00 \\
3 & $-12,000$ & 8,059 & 1,87 \\
4 & $-15,000$ & 8,145 & 0,80 \\
5 & $-3,700$ & 1,081 & 1,00 \\
7 & $-1,500$ & 0,570 & 0,25 \\
& & & 0,10 \\
\hline
\end{tabular}

A Tabela 6.19 apresenta a comparação entre os resultados obtidos para cada um dos métodos abordados neste item. 
Tabela 6.19 - Comparação dos valores aplicáveis de correção atmosférica para cada
método descrito.

\begin{tabular}{|c|c|c|c|c|}
\hline \multirow{2}{*}{ Bandas (TM) } & \multicolumn{4}{|c|}{ Métodos } \\
\cline { 2 - 5 } & A & B & C & D \\
\hline $\mathbf{1}$ & 53 & 61 & 52,9 & 53 \\
\hline $\mathbf{2}$ & 16 & 20 & 29,7 & 55,7 \\
\hline $\mathbf{3}$ & 13 & 17 & 15,4 & 12,4 \\
\hline $\mathbf{4}$ & 8 & 20 & 6,2 & 6,3 \\
\hline $\mathbf{5}$ & 3 & 11 & 0,4 & 0,1 \\
\hline $\mathbf{7}$ & 1 & 4 & 0,1 & 0 \\
\hline
\end{tabular}

A - Seleção por histograma de freqüência (método do histograma);

C - Modelo de pixel escuro;

D - Modelo de espalhamento simples (Atmosfera Muito limpa) - Chavez (1988);

O capítulo 8 apresenta os resultados da aplicação do método de Chavez (1988) para as imagens do satélite Landsat 7 utilizadas na caracterização do uso do solo atual no município. Os valores de calibração para o Landsat 7 são fornecidos conjuntamente com os arquivos de imagens e apresentam modificações para cada área geográfica e data, em função das condições atmosféricas de cada local, permitindo aplicar o método de correção descrito com resultados melhores do que os apresentados, como exemplo, na Tabela 6.19.

Outro método simplificado de correção atmosférica descrito na literatura (Novo, 1989) é o método de correlação entre canais, que realiza a comparação entre dois canais altamente correlacionados. Considerando que a alta correlação entre os canais deveria resultar em uma reta média passando pela origem, o valor em que a reta cruza o eixo y é considerado como o valor adicionado pela interferência atmosférica.

\subsubsection{Correção geométrica}

Segundo Lillesand e Kiefer (1994) imagens de sensoriamento remoto, em seu formato original, geralmente contêm distorções geométricas muito significativas, o que pode impedir a utilização direta dessas imagens como mapas.

As fontes dessas distorçōes variam desde oscilações na altitude, direção e velocidade da plataforma do sensor, a fatores relacionados à distorção panorâmica, 
curvatura da Terra, refração atmosférica, disposição do relevo, e falhas na varredura do IFOV ${ }^{7}$ do sensor.

O objetivo da correção geométrica é de compensar as distorções introduzidas por estes fatores de forma que a imagem corrigida apresente a integridade geométrica de um mapa.

A correção geométrica de imagens de sensoriamento remoto é uma etapa fundamental durante o pré-processamento, permitindo que os produtos derivados estejam em um formato georreferenciado de fácil utilização e integração com outros dados de sensoriamento remoto e geoprocessamento.

A correção geométrica pode empregar diversos modelos matemáticos. O modelo polinomial, que se baseia na transformação polinomial da imagem utilizando diversos pontos de controle, é um dos mais utilizados. Os pontos de controle devem ser locados de forma bem distribuida na imagem, podendo ser obtidos em mapa ou imagem. A transformação polinomial requer um número mínimo de pontos de controle em função do grau do polinômio empregado na aproximação, para um polinômio de grau $\mathbf{n}$ o número de pontos é dado pela equação:

$$
G C P=\frac{\left(n^{2}+3 n+2\right)}{2}
$$
Onde GCP(Ground Control Points) corresponde ao número de pontos de controle; $n=$ grau do polinômio
utilizado;

Após ser feita a correção da grade é necessário que se faça a atribuição do novo conjunto de pixels criados. O cálculo dos valores dos pixels pode empregar um dos 3 métodos de interpolação: vizinho mais próximo, interpolação bi-linear e convolução cúbica. As principais diferenças entre os métodos são apresentadas na Tabela 6-20, sendo que a escolha do método depende principalmente da aplicação a que se destina a imagem.

Tabela 6-20 - Comparação de métodos utilizados para interpolação dos valores da imagem corrigida geometricamente.

\begin{tabular}{|c|c|c|c|c|}
\hline Método & Técnica & $\begin{array}{c}\text { Tempo relativo } \\
\text { de cálculo }\end{array}$ & Vantagens & Desvantagens \\
\hline $\begin{array}{c}\text { Vizinho mais } \\
\text { próximo }\end{array}$ & $\begin{array}{c}\text { Transfere o DN do } \\
\text { vizinho mais próximo }\end{array}$ & 1 & $\begin{array}{c}\text { Simples de calcular; } \\
\text { preserva o DN original }\end{array}$ & $\begin{array}{c}\text { Imagem pouco } \\
\text { estética }\end{array}$ \\
\hline $\begin{array}{c}\text { Interpolação } \\
\text { bi-linear }\end{array}$ & $\begin{array}{c}\text { Calcula a média } \\
\text { ponderada dos 4 vizinhos }\end{array}$ & 10 & $\begin{array}{c}\text { Imagem suave; } \\
\text { geometricamente correta }\end{array}$ & $\begin{array}{c}\text { Altera o o DN do } \\
\text { pixel original }\end{array}$ \\
\hline $\begin{array}{c}\text { Convolução } \\
\text { cúbica }\end{array}$ & $\begin{array}{c}\text { Utiliza uma média } \\
\text { dos } 16 \text { vizinhos próximos }\end{array}$ & 20 & $\begin{array}{c}\text { Imagem esteticamente } \\
\text { melhor }\end{array}$ & $\begin{array}{c}\text { Complexa de } \\
\text { calcular }\end{array}$ \\
\hline
\end{tabular}

Fonte: Crósta (1992).

7 IFOV (Instantaneous Field of View) - Campo instantâneo de visada - E determinado pelas propriedades geométricas do sistema sensor e define a área do terreno imageado que é processada pelo instrumento sensor em uma dada altitude e momento e, de forma simplificada, ele representa o tamanho do pixel. 
A interpolação por vizinho mais próximo utiliza o valor do pixel da imagem de entrada que possui o centro mais próximo do ponto localizado na imagem de saída. $O$ valor do pixel permanece inalterado, sendo que apenas sua posição foi modificada. A interpolação bi-linear designa valores de brilho para pixels da imagem de saída pela interpolação de duas direções ortogonais, o que envolve cada um dos quatro pixels que circundam o ponto encontrado na imagem correspondente à grade de localização. $O$ valor do pixel para a imagem corrigida (de saída) é ponderado, usando a distância linear entre os centros dos pixels de entrada e o centro do pixel de saída. $O$ valor médio dos quatro valores ponderados do brilho dos pixels de entrada será então o valor do pixel de saída.

A convolução cúbica designa o valor de brilho da imagem de saída pelo mesmo procedimento de interpolação bilinear, mas leva em conta os valores ponderados de 16 pixels que circundam o ponto encontrado na imagem correspondente à grade de localização do pixel.

Para interpretação visual é aconselhável utilizar as imagens geradas por convolução cúbica ou interpolação bilinear, já as imagens geradas por interpolação por vizinho mais próximo são mais adequadas para a aplicação de técnicas de classificação (Crósta, 1992).

\subsubsection{Classificação}

O objetivo geral dos procedimentos de classificação de imagens é categorizar automaticamente todos os pixels de uma imagem em um conjunto de classes de cobertura.

Os dados multiespectrais normalmente são utilizados para se realizar a classificação, permitindo definir padrões espectrais presentes nos dados para cada pixel, que são utilizados como base numérica para categorização, ou seja, diferentes coberturas apresentarão combinações distintas de DNs baseando-se em suas reflectâncias espectrais inerentes e propriedades de emitância.

O termo "padrão" espectral não tem um caráter completamente geométrico, pois se refere à série de medidas de radiância obtidas nas várias bandas espectrais para cada pixel. O reconhecimento espectral de padrões refere-se então ao conjunto de procedimentos de classificação que utilizam essa informação espectral, pixel a pixel, como base para a classificação automática da imagem. 
O reconhecimento do padrão espectral envolve a categorização dos pixels da imagem com base em seu relacionamento espacial com os pixels ao redor. Classificadores espaciais devem considerar os seguintes aspectos: textura da imagem, proximidade de determinados pixels, tamanho da feição, forma, direção, repetição e contexto. Esses tipos de classificadores tentam reproduzir o tipo de sintese espacial feita pelo analista humano durante 0 processo de interpretação visual. Conseqüentemente, essa abordagem tende a ser muito mais complexa e computacionalmente intensiva do que procedimentos de reconhecimento de padrões espectrais.

O reconhecimento de padrões temporais utiliza o tempo como auxilio na identificação de feições. Nos levantamentos de áreas de cultivo, por exemplo, mudanças espectrais durante o período de crescimento podem permitir a diferenciação de tipos de cultura, utilizando-se imagens de várias datas, o que não seria possivel utilizando-se uma única imagem. A interpretação de imagens de uma única data seria mal sucedida, independentemente do número de bandas espectrais. Caso os dados de duas datas características fossem analisados, o tipo de cultivo poderia ser prontamente identificado, desde que não existam na imagem outras áreas com comportamento espectral característico semelhante nas mesmas datas em análise.

Lillesand e Kiefer (1994) destacam ainda que como em outras técnicas de tratamento de imagens a classificação pode ser utilizada empregando-se diferentes abordagens ou classificadores em uma combinação híbrida. Também não há um único procedimento "correto" de abordagem no problema de classificação de imagens. A abordagem particular dependerá da natureza dos dados sendo analisados, os recursos computacionais disponiveis e a aplicação desejada dos dados classificados.

\subsubsection{Classificação não supervisionada}

A classificação não supervisionada não utiliza dados de controle (training data) como base para a classificação. Ao contrário, essa abordagem envolve algoritmos que examinam os pixels de uma imagem e os agrega em um número de classes baseandose no agrupamento natural (cluster) apresentado pelos valores da imagem. A premissa básica é que os valores dos pixels em um dado tipo de cobertura deveriam ser bastante próximos no espaço de medição, portanto dados em classes diferentes devem ser comparativamente bem separados.

As classes que resultam da classificação não supervisionada são consideradas classes espectrais, pois se baseiam no agrupamento natural dos valores da imagem. A 
identidade das classes espectrais resultantes é avaliada pelo analista, que compara os dados classificados com alguma referência (fotografias ou mapas), determinando o valor informativo de cada classe espectral.

$\mathrm{Na}$ classificação supervisionada as classes presentes em uma imagem são definidas pelo analista que utiliza um classificador que examina a separabilidade espectral para cada classe definida, enquanto que na abordagem não supervisionada as classes são criadas por serem espectralmente separáveis e posteriormente definese seu significado.

Geralmente a abordagem empregada na classificação não supervisionada é útil para mostrar classes que, normalmente em uma abordagem supervisionada, poderiam ter sido ignoradas, cabendo ao analista identificar estas classes associando a um significado, pois esse tipo de classificação identifica classes espectrais distintas. Muitas dessas classes podem não ser visiveis para o analista que está utilizando uma classificação supervisionada. Por outro lado, as classes espectrais em uma cena podem ser tão numerosas que seria difícil adquirir áreas de treinamento (training sites) para todas as classes, enquanto que na abordagem não supervisionada as classes são definidas automaticamente.

Vários são os algoritmos de agrupamento (clustering) que podem ser utilizados para determinar o agrupamento espectral natural presente em um conjunto de dados (imagem).

\subsubsection{K-médias ( $k$-means)}

Esta abordagem exige que o analista defina um número de classes (agrupamentos) a serem localizados nos dados. O algoritmo então arbitrariamente localiza o número de agrupamentos no espaço multi-dimensional de medidas. Cada pixel da imagem é então atribuido ao agrupamento cujo vetor médio (mean vector) está mais próximo. Após todos os pixels terem sido classificados desta maneira, os vetores médios para cada um dos agrupamentos são recalculados (armazenados). Os valores recalculados das médias são então utilizados como base para a reclassificação dos dados da imagem. O procedimento continua até que não ocorra mudança significativa na localização do vetor médio da classe entre interações sucessivas do algoritmo, conforme os parâmetros de entrada especificados.

Após a conclusão deste processo o analista determina a identidade da cobertura da terra de cada classe espectral determinada durante a classificação. Devido à interatividade da abordagem do algoritmo descrito (K-means) ele é 
computacionalmente intensivo. Entretanto, essa abordagem é freqüentemente aplicada somente para sub-áreas da imagem ao invés da imagem completa. Tais sub-áreas são freqüentemente referenciadas como "áreas de treinamento não supervisionadas" e não devem ser confundidas com as áreas de treinamento utilizadas na classificação
supervisionada.

Enquanto as áreas de treinamento da abordagem supervisionada são localizadas em regiōes com coberturas homogêneas, as áreas de treinamento "não supervisionadas" são tomadas para conter numerosos tipos de cobertura em vários locais por toda a cena. Isso assegura que todas as classes espectrais na cena são representadas em algumas das sub-áreas tomadas. Essas áreas são então agrupadas independentemente $\mathrm{e}$ as classes espectrais de cada uma das várias áreas são analisadas para determinar a sua identidade. Essas classes são então analisadas segundo uma abordagem estatística conjunta para determinar sua separabilidade
espectral.

As classes que apresentam agrupamentos semelhantes que representam coberturas similares são combinadas. As estatisticas gerais para todas as areas combinadas (e classes) são então utilizadas para classificar a cena completa (utilizando uma classificação por mínima distância ou máxima verossimilhança).

Essa abordagem que envolve etapas da classificação supervisionada e não supervisionada é referida como uma classificaçăo híbrida (hybrid classification).

Os classificadores híbridos são particularmente interessantes em análises onde ocorre uma grande e complexa variabilidade nos padrões de resposta espectral para tipos individuais de coberturas presentes. Essas condições são muito comuns em aplicações tais como mapeamento de vegetação em áreas montanhosas. Sob essas condições de terreno a variabilidade espectral em um mesmo tipo de cobertura normalmente origina-se por: variação da cobertura vegetal e mudanças nas condições locais (solo, declividade e aspecto). A classificação híbrida é uma abordagem que auxilia o analista a lidar com tal variabilidade.

\subsubsection{Classificação supervisionada}

$\mathrm{Na}$ classificação supervisionada de uma imagem o analista "supervisiona" o processo de categorização por especificar, para o algoritmo que está sendo utilizado, uma descrição numérica dos vários tipos de coberturas presentes em uma cena. $O$ processo inicia-se com a amostragem de áreas representativas de tipos de cobertura conhecidos, chamadas áreas de treinamento (training sites) que são utilizadas para 
gerar uma chave de interpretação numérica (interpretation key) que descreve os atributos espectrais para cada tipo de feição de interesse.

Cada pixel da imagem é então comparado numericamente com cada categoria da chave de interpretação e então é classificado, ou rotulado, com o nome da categoria que mais se aproxima.

Existem várias estratégias que podem ser empregadas na comparação entre os pixels "desconhecidos" e os pixels pertencentes às áreas de treinamento, os classificadores: minima distância, paralelepípedo, máxima verossimilhança

\subsubsection{Mínima distância}

É uma das abordagens mais simples disponíveis de classificação. Primeiramente cada categoria é analisada quanto a média dos valores espectrais em cada banda. Os valores são então armazenados como vetores de média (mean vetor) para cada categoria. O pixel a ser classificado tem seus valores comparados com os vetores de média para cada banda, sendo que o pixel será atribuído para o vetor de média mais próximo, ou caso a "distância" seja maior do que um valor pré-definido pelo analista em relação a todos os vetores de média, o pixel será classificado como "desconhecido".

Essa abordagem é matematicamente simples e computacionalmente eficiente, contudo apresenta limitações relacionadas principalmente a falta de sensibilidade para dados que apresentem diferentes graus de variância na resposta espectral. A Figura 6.8 exemplifica o processo de classificação em que o pixel a ser identificado pode estar mais próximo de um vetor de média de uma classe com pequena variância na resposta espectral, mas contudo pertence a outra classe com maior variância na resposta espectral, sendo classificado erroneamente. Por essa característica esse classificador não é amplamente utilizado, principalmente em aplicaçōes que encontram classes espectrais muito próximas no espaço de medidas e apresentam alta variância.

\subsubsection{Paralelepípedo}

Nessa abordagem o classificador considera a variação dos valores de cada categoria das áreas de treinamento, dessa forma, introduzindo sensibilidade à variância das categorias. Essa variação pode ser definida pelos valores maiores e menores de DN em cada banda espectral, e visualmente aparecem como um retângulo, como apresentado na Figura 6.9. O pixel é então classificado de acordo com a variação da 
categoria, ou região de decisão, na qual é englobado, ou é classificado como desconhecido caso não seja englobado em uma região. No espaço multidimensional, as áreas retangulares são chamadas de paralelepipedos. Esse classificador é também muito rápido e computacionalmente eficiente.

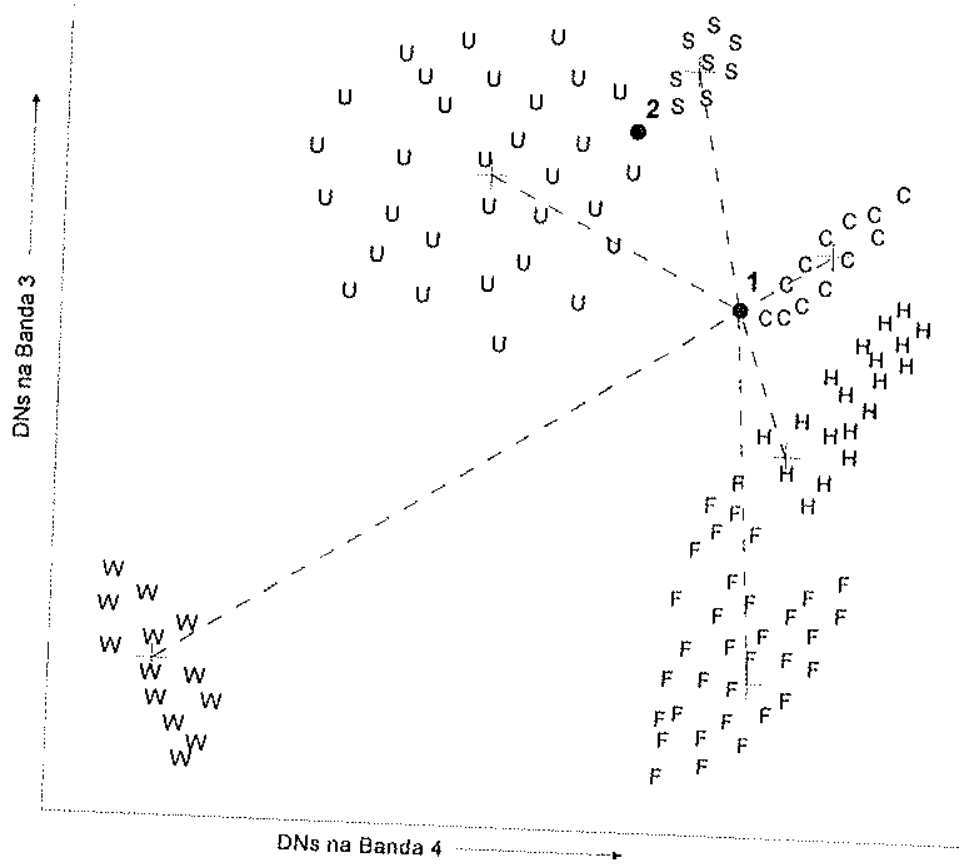

Figura 6.8 - Conjunto de dados, de duas bandas espectrais, exemplificando como o classe com pequena variância na respostancia pode utilizar um vetor de média de uma

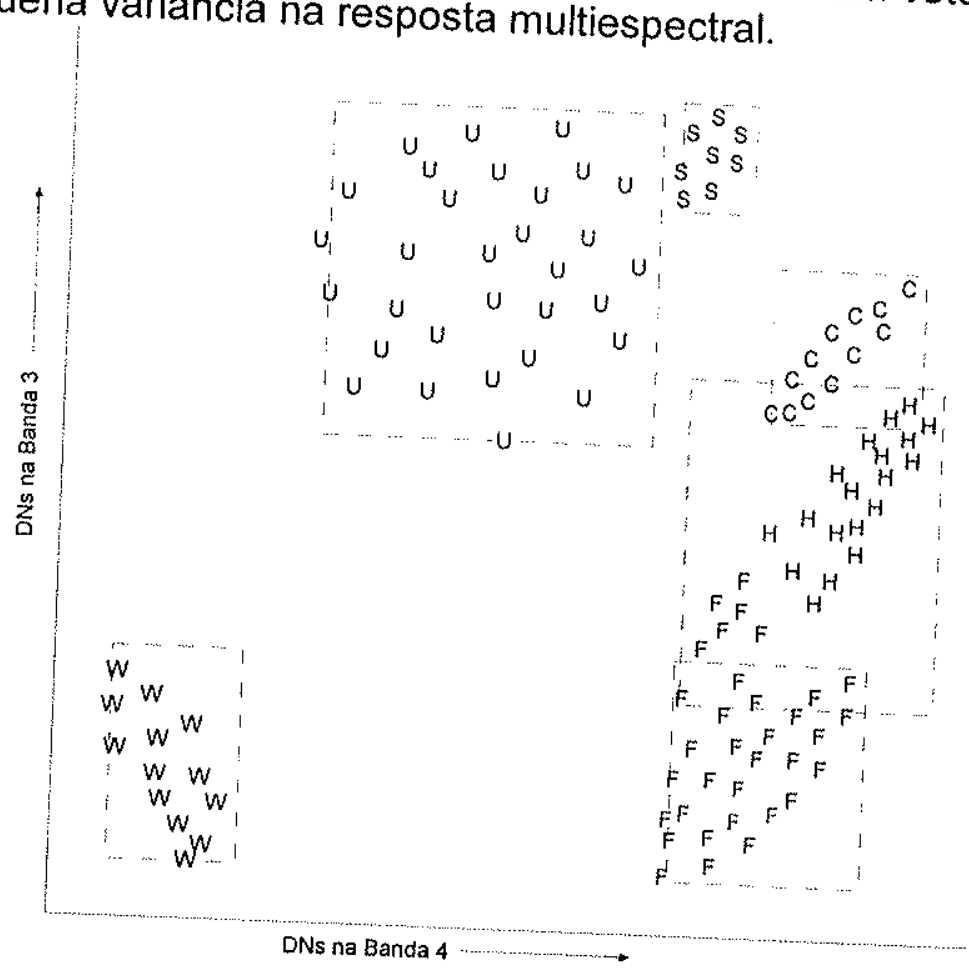

Figura 6.9 - Comparação entre as menores "regiões de decisão" S e W (areia e água) e maiores $\mathrm{U}$ e $\mathrm{H}$ (áreas urbanas e pastagens), pela abordagem do paralelepipedo. 
A sensibilidade desse classificador para a variância de cada categoria pode ser observada na Figura 6.9 comparando-se as menores "regiões de decisão" (areia e água), com as maiores (área urbana e pastagem). Dessa forma o pixel 2 seria classificado apropriadamente como uma área urbana. Contudo, problemas ocorrem entre as categorias que se sobrepõem, pois pixels que caiam nas áreas de sobreposição serão atribuídos como incertos ou serão arbitrariamente classificados em uma das duas classes. A sobreposição é causada em grande parte devido a correlação existente entre as categorias, ou uma alta covariância que é fracamente descrita pelas regiões de decisões retangulares. A covariância é a tendência dos valores espectrais variarem de forma similar nas duas bandas, resultando em nuvens de pontos alongadas no diagrama. Na Figura 6.9 é possível visualizar as categorias $\mathrm{C}$ (milho) e $\mathrm{H}$ (pastagem) com covariância positiva, o que significa que valores altos na banda 3 estão associados com valores altos na banda 4 . A categoria W (água) apresenta uma covariância negativa, o que significa que valores altos na banda 3 estão associados com valores baixos na banda 4. A categoria $U$ (área urbana) não apresenta covariância, o que resulta numa distribuição aproximadamente circular da nuvem de dados.

Na presença de covariância, as regiöes de decisão tomam uma forma irregular, praticamente não se ajustando aos dados de treinamento, o que resulta na confusão para o classificador do tipo paralelepípedo.

Geralmente os padrões de respostas espectrais são altamente correlacionados e apresentam alta covariância, o que pode inviabilizar a utilização dessa abordagem, apesar de sua eficiência computacional.

\subsubsection{Máxima verossimilhança}

O classificador por máxima verossimilhança avalia quantitativamente a covariância e variância dos padrões de resposta espectral das categorias quando realiza a classificação de um dado pixel. Nesse procedimento é feita a suposição de que a distribuição da nuvem de pontos que forma cada categoria é gaussiana (distribuição normal). Essa suposição de normalidade é geralmente razoável para a distribuição de respostas espectrais comuns. Nessa abordagem a distribuição do padrão de resposta de cada categoria pode ser completamente descrito pela matriz de covariância e vetor de média. Dados esses parâmetros pode-se calcular a probabilidade estatística de um pixel pertencer a uma classe particular. A Figura 6.10 mostra os valores de probabilidade lançados em um gráfico tridimensional, onde o eixo $Z$ está associado com a probabilidade de um pixel pertencer a uma determinada 
classe. A forma de sino das superfícies são chamadas de função de densidade de probabilidade, existindo uma função para cada categoria espectral.

As funções de densidade de probabilidade são utilizadas na classificação de cada pixel. O classificador calcula a probabilidade de cada pixel pertencer às classes que ocorrem e, após avaliar a probabilidade de cada categoria, ou atribui àquela com maior valor de probabilidade, ou atribui o pixel como "desconhecido", caso os valores de probabilidade estejam abaixo de um limiar definido pelo analista.

A Figura 6.11 apresenta as regiões de decisão para o classificador por máxima verossimilhança, definidas pelos contornos de equiprobabilidade. A forma dos contornos expressa a sensibilidade do classificador de máxima verossimithança para a covariância, permitindo apropriada classificação dos pixels em cada categoria.

A principal desvantagem dessa abordagem é o grande número de operações matemáticas necessárias para classificar cada pixel, o que é particularmente verdadeiro quando, ou um grande número de bandas espectrais estão envolvidas ou um grande número de classes espectrais devem ser diferenciadas. Em tais casos, o classificador por máxima verossimilhança é muito mais lento computacionalmente do que as técnicas anteriores. Algumas abordagens podem ser utilizadas para aumentar a eficiência da classificação por máxima verossimithança, como por exemplo, o emprego de um método para reduzir as dimensões dos dados utilizados para executar a classificação.

Classificadores do tipo estratificado, em camadas e árvore de decisão também podem ser utilizados para reduzir o número de operações durante a classificação e mantendo a decisão da classificação. Esses classificadores são aplicados em uma série de passos, separando-se algumas classes durante cada etapa da maneira mais simples possivel. A separação de classes espectralmente bem definidas como água, por exemplo, pode ser realizada previamente utilizando-se uma banda do infravermelho próximo, baseando-se em um limiar pré-definido.

\subsubsection{Avaliação da exatidão da classificação}

Os produtos gerados a partir das técnicas de classificação de imagens, seja supervisionada ou não-supervisionada, devem passar por uma avaliação de sua exatidão. Lillesand e Kiefer (1994) afirmam que uma classificação não está completa até que sua exatidão seja avaliada. 


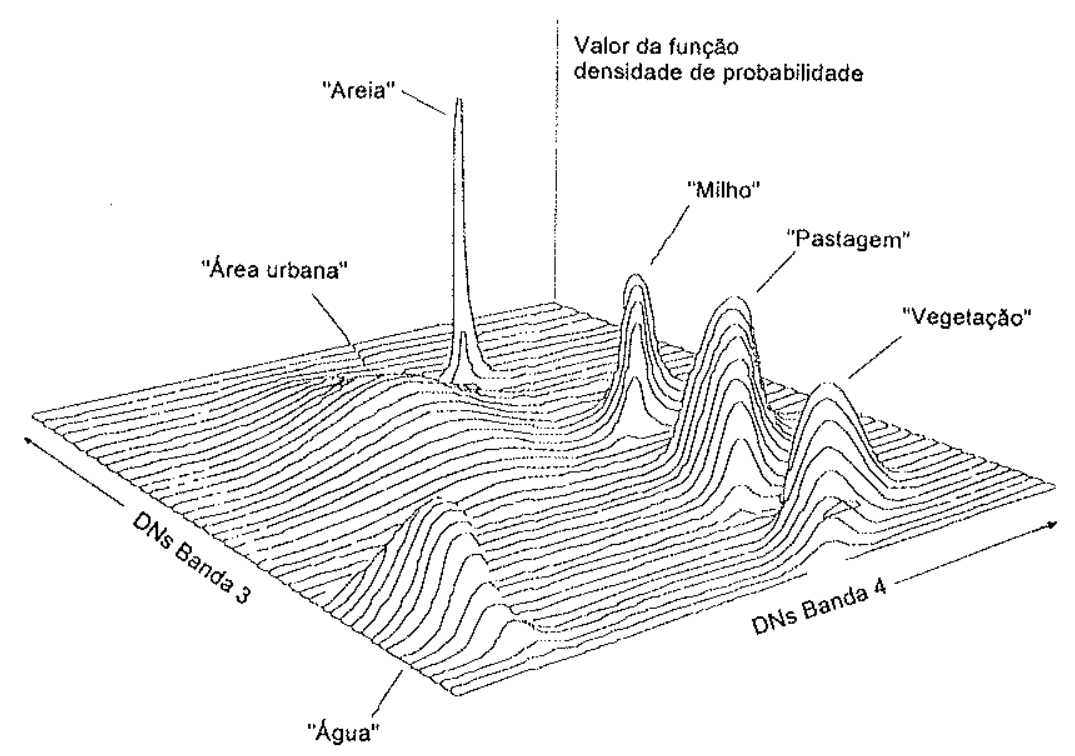

Figura 6.10 - Valores de probabilidade associados ao conjunto de pixels representando as classes analisadas.

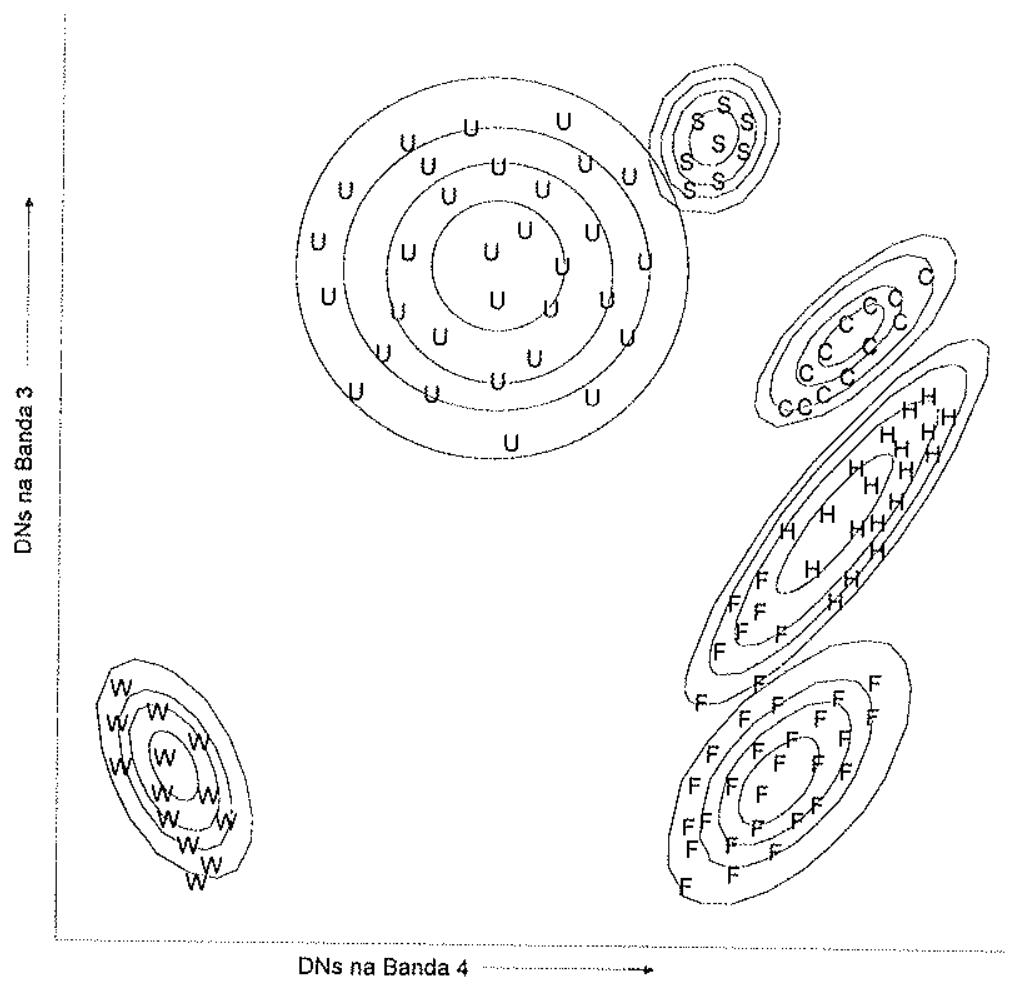

Figura 6.11 - Contornos de eqüiprobabilidade que representam as regiöes de decisão para o classificador por máxima verossimilhança.

\subsubsection{Matriz de erro da classificação}

A maneira mais comum de expressar a exatidão da classificação é através da preparação de uma matriz de erro da classificação (também chamada de matriz de confusão ou tabela de contingência). As matrizes de erro comparam as relações entre os dados de referencia conhecidos (verdade de campo) e os resultados correspondentes de uma classificação automática. Tais matrizes são do tipo quadrado, 
com números de linhas e colunas iguais ao número de categorias cuja exatidão da classificação está sendo avaliada.

A Tabela 6.21 exemplifica como é uma matriz de erro produzida para determinar como a classificação categorizou uma amostragem representativa de pixels utilizados no processo de treinamento de uma classificação supervisionada.

Essa matriz é produzida com base nos pixels das amostras de treinamento, que são classificados conforme o tipo de cobertura utilizada no treinamento, relacionado nas colunas, em relação aos pixels realmente classificados em cada categoria de cobertura, pelo classificador, relacionados nas linhas.

Várias características sobre o desempenho da classificação são expressas pela matriz de erro. Por exemplo, pode-se estudar os vários erros de classificação, de omissão (exclusão) e comissão (inclusão). É possivel observar na Tabela 6.21 que os pixels do conjunto de treinamento que são classificados nas categorias de coberturas corretas estão localizados ao longo da diagonal maior da matriz de erro (da esquerda superior para a direita inferior). Todos os elementos fora da diagonal principal da matriz representam erros de omissão ou comissão. Erros de omissão correspondem aos elementos que estão nas colunas fora da diagonal principal (por exemplo, 16 pixels que deveriam ter sido classificados como "areia" foram omitidos dessa categoria). Erros de comissão são representados pelos elementos das linhas fora da diagonal principal (por exemplo, 38 pixels da categoria "área urbana" e mais 79 pixels da categoria "pastagem" foram indevidamente incluídos na categoria "milho").

Muitas outras medidas descritivas podem ser obtidas a partir da matriz de erro. Por exemplo, a exatidão geral (overall accuracy) é calculada pela divisão do número total de pixels corretamente classificados (a soma dos elementos ao longo da diagonal maior) pelo número total de pixels de referência. Dessa forma, a exatidão das categorias individuais podem ser calculadas dividindo-se o número de pixels corretamente classificados em cada categoria pelo número total de pixels na linha ou coluna correspondente. A exatidão do produtor (producer's accuracies) é o resultado da divisão do número de pixels classificados corretamente em cada categoria (na diagonal maior) pelo número de pixels do conjunto de treinamento utilizados para aquela categoria (o total da coluna). Esse resultado indica como o conjunto de pixels de treinamento para dado tipo de cobertura são classificados. A exatidão do usuário (user's accuracies) é calculada pela divisão do número de pixels classificados corretamente em cada categoria pelo número total de pixels que foram classificados naquela categoria (o total da linha). Esse resultado é uma medida do erro de comissão 
e indica a probabilidade que um pixel classificado em uma dada categoria realmente representa aquela categoria no terreno.

Observa-se na matriz de erro, na Tabela 6.21 , uma exatidão geral de $84 \%$, contudo a exatidão do produtor varia de $51 \%$ (área urbana) para $100 \%$ (água) e a exatidão do usuário varia de $72 \%$ (areia) para $99 \%$ (água). Além disso, essa matriz de erro é baseada nos dados de treinamento. Esse procedimento somente indica a utilidade das estatísticas extraídas dessas áreas para categorizar o conjunto. Caso os resultados sejam bons, isso significa apenas que as áreas de treinamento são homogêneas e as classes de treinamento são classes espectralmente separáveis e a estratégia de classificação que está sendo empregada funciona corretamente para as áreas de treinamento. Esses resultados auxiliam no processo de refinamento do conjunto de treinamento mas indicam pouco sobre o desempenho do classificador em outras áreas da imagem.

Tabela 6.21 - Matriz de erro resultante dos dados de treinamento para classificação supervisionada.

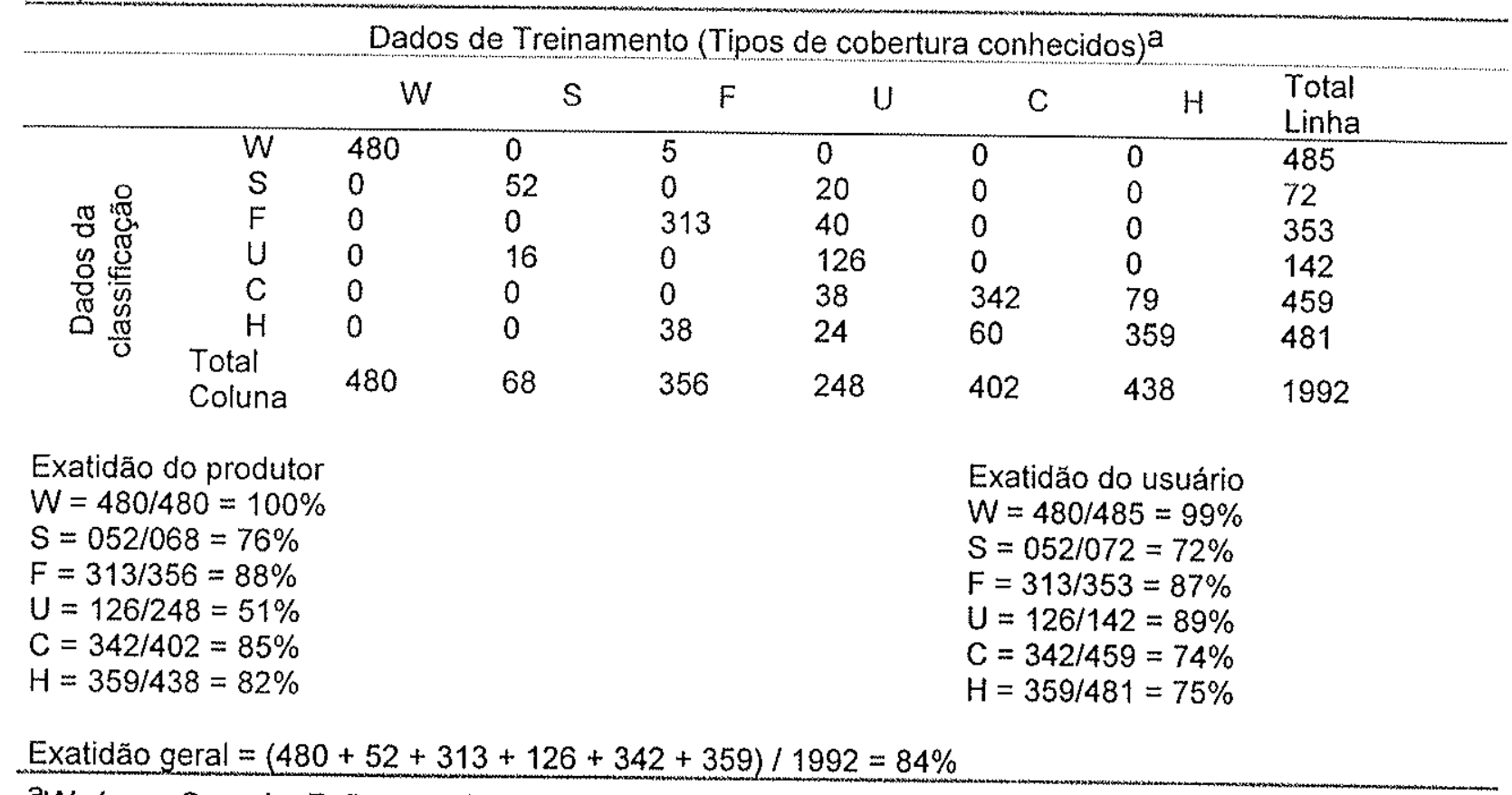

aW, água, $S$, areia; $F$, floresta; $U$, área urbana; $C$, cultivo de milho; $H$, pastagem

Fonte: Lillesand e Kiefer (1994).

\subsubsection{Considerações sobre amostragem}

Áreas de teste são áreas representativas, com cobertura uniforme que são diferentes e consideravelmente mais extensas que áreas de treinamento. Essas áreas são freqüentemente localizadas durante o estágio de treinamento da classificação 
supervisionada por intencionalmente elaborar mais áreas de treinamento do que o realmente necessário para o processamento estatístico da classificação. Uma parte desses dados pode então ser reservada para a avaliação da exatidão da classificação. A exatidão obtida nessas áreas representa pelo menos uma primeira aproximação do desempenho da classificação na imagem. Contudo, sendo homogêneas, as áreas testes podem não proporcionar uma indicação válida da exatidão da classificação em relação à variabilidade individual dos pixels.

A abordagem que poderia assegurar uma avaliação adequada da exatidão da classificação em relação a pixels poderia ser a comparação da classificação da cobertura em cada pixel da imagem com uma referência adicional, o que é viável em áreas reduzidas.

A amostragem aleatória de pixels resolve a limitação da abordagem anterior, mas apresenta outras limitações. A primeira limitação relaciona-se à dificuldade de obter dados de referência para uma ampla amostragem de pontos aleatoriamente distribuídos, pois muitas vezes é inviável percorrer as distâncias e ter acesso a locais aleatoriamente escolhidos. A segunda limitação relaciona-se à validação da localização das amostras aleatórias no campo, o que depende do correto registro aos dados de referência da imagem.

Outro procedimento, que pode ser empregado, relaciona-se à elaboração de uma malha retangular sobre o resultado da classificação (estratificação); cada ponto dessa malha engloba vários pixels. Essa malha é então utilizada como referência para a amostragem aleatória (amostragem estratificada aleatória), que por sua vez está selecionando um grupo de pixels para avaliação. Os dados sobre o tipo de cobertura classificada são então comparados, ou com outros dados de referência, ou com base na verificação de campo.

O procedimento de avaliação da exatidão mais adequado a ser empregado pode ser uma combinação das abordagens mencionadas. Inicialmente pode-se realizar uma amostragem sistemática para a obtenção de alguma informação prévia a respeito da exatidão e, com a finalização da classificação deve-se utilizar uma amostragem aleatória no conjunto de dados.

A unidade de amostra utilizada na avaliação de exatidão dependerá da aplicação, que determina se a unidade de amostragem deverá ser representada por poligonos, agrupamentos de pixels ou pixels individuais.

O tamanho da amostra pode variar em função das dimensões da área analisada, devendo ser de, no minimo, de 50 amostras para cada categoria de vegetação ou uso do solo, até 100 amostras, com o aumento da área ou devido ao grande número de 
categorias a serem analisadas. A quantidade de amostras em cada categoria pode ser melhor definida levando-se em consideração alguns aspectos: importância da categoria para a aplicação dos dados, maior variabilidade dentro da categoria (um menor número de amostras pode ser tomado em categorias com menor variação, tais como corpos d'água).

\subsubsection{Avaliação das Matrizes de erro}

Após a coleta de dados de controle (seja na forma de pixels, agrupamentos de pixels, ou polígonos) a matriz de erro é refeita, devendo-se realizar então uma interpretação detalhada seguida de uma análise estatistica dos dados.

A Tabela 6.22 apresenta os mesmos dados do exemplo anterior com a geração da matriz de erro utilizando-se de dados de referência adicionais, com amostragem aleatória. É possivel verificar uma exatidão geral de $65 \%$, contudo caso o interesse para a aplicação do produto seja o levantamento das áreas de florestas pode-se verificar que a exatidão do produtor, para esta categoria, é de $84 \%$. Esse resultado indica uma melhor qualidade da classificação na categoria Floresta, apesar de uma baixa exatidão geral $(65 \%)$, contudo deve-se considerar também que a exatidão do usuário obtida nesta categoria foi de $60 \%$, o que significa que apesar de $84 \%$ das áreas de floresta terem sido corretamente identificadas como "floresta", somente $60 \%$ das áreas identificadas como "floresta" correspondem realmente àquela categoria.

A observação da matriz de erro da Tabela 6.22 permite ainda verificar a significativa confusão entre as classes "área urbana" e "floresta", que apesar da avaliação do "produtor da classificação" declarando que $84 \%$ das vezes uma área que estava florestada foi identificada como tal, o "usuário da classificação" encontraria (no campo) em somente $60 \%$ das áreas, o que a classificação considera como "floresta", como realmente florestadas. A única categoria classificada na Tabela 6.21 que apresenta-se altamente confiável, tanto do ponto de vista do usuário como do produtor, é a categoria "água".

\subsubsection{A estatística Kappa $(k)$}

A utilização de uma amostragem aleatória para a definição das áreas testes pode gerar uma avaliação aparente da classificação extremamente boa, levando a uma supervalorização dos resultados, que muitas vezes podem estar relacionados a um 
acerto casual. A estatística kappa (ou coeficiente) pode ser entendida como uma medida das diferenças entre: a concordância real entre os dados de referência e aqueles gerados pelo classificador automático e, a possibilidade de concordância entre os dados de referência e um classificador aleatório.

Tabela 6.22 - Matriz de erro resultante dos dados de teste selecionados aleatoriamente na imagem resultante da classificação supervisionada.

$$
\text { Dados de referencia (aleatoriamente coletados em campo }
$$
e com base em outros produtos de sensoriamento remoto) ${ }^{a}$

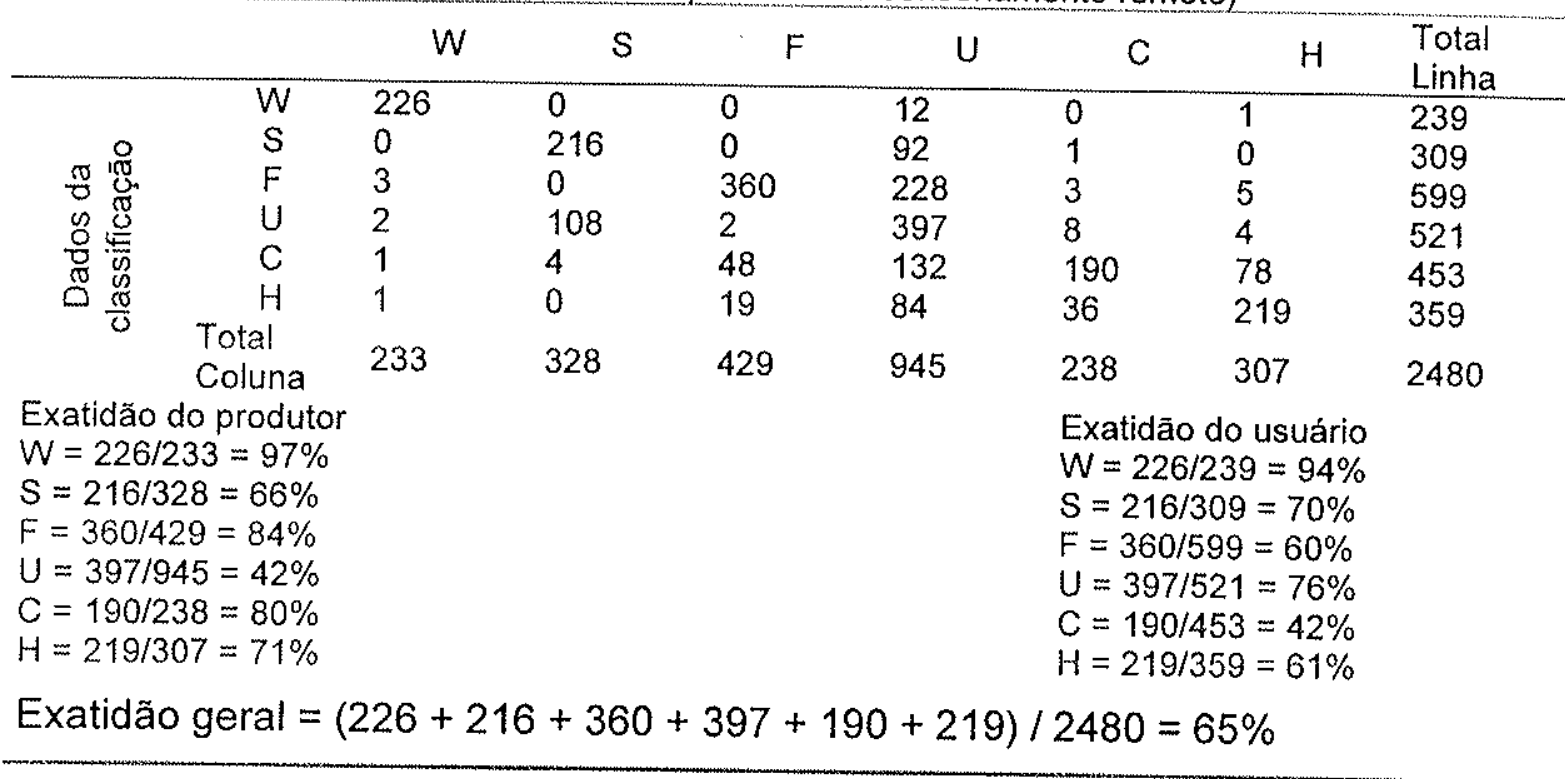

$a W$ água, $S$, areia; $F$, floresta; $U$, área urbana; $C$, milho; $H$, pastagem

Fonte: Lillesand e Kiefer (1994).

Essa estatística funciona como um indicador de como os valores indicados como porcentagem de acertos, de uma matriz de erro, estão relacionados a uma concordância real e não a uma concordância ao acaso. O valor de 1 indica uma concordância real, enquanto o valor 0 indica uma concordância totalmente ao acaso. Os valores de kappa podem variar dentro deste limite. $O$ valor de $k=0.67$ indicaria, por exemplo, que a classificação analisada é $67 \%$ melhor do que um resultado tomado ao acaso. Valores negativos de $k$ podem ser encontrados, contudo indicam um péssimo desempenho da classificação.

O indice kappa é calculado conforme a seguinte equação:

$$
k=\frac{N \sum_{i=1}^{r} x_{i i}-\sum_{i=1}^{r}\left(x_{i+} \cdot x_{+i}\right)}{N^{2}-\sum_{i=1}^{r}\left(x_{i+} \cdot x_{+i}\right)}
$$

Onde

$r=$ número de linhas na matriz de erro;

$\mathrm{x}_{\mathrm{ii}}=$ ao número de observações na linha i e coluna i (na diagonal maior);

$x_{i+}=$ total de observações na linha $i$ (indicado na tabela como total marginal à direita da matriz);

$x_{+i}=$ total de observaçöes na coluna $i$ (indicado como total marginal na base da matriz);

$\mathrm{N}=$ número total de observações incluídas na matriz; 
O cálculo da estatística kappa, para a matriz apresentada na Tabela 6.22, é apresentado abaixo:

$$
\begin{gathered}
\sum_{i=1}^{r} x_{i i}=226+216+360+397+190+219=1608 \\
\sum_{i=1}^{r}\left(x_{i+} \cdot x_{+i}\right)=(239.233)+(309.328)+(599.429)+(521.945) \\
+(453.238)+(359.307)=1124382 \\
k=\frac{2480(1608)-1124382}{(2480)^{2}-1124382}=0.57
\end{gathered}
$$

O valor obtido para o coeficiente kappa é menor do que o valor de exatidão geral $(0.65)$ calculado anteriormente. Essas diferenças estão relacionadas às características de cada estimativa, que levam em consideração fatores diferentes da matriz de erro.

O cálculo da exatidão geral leva em consideração somente os dados presentes na diagonal principal excluindo os erros de omissão e comissão, enquanto que a estatística kappa incorpora os elementos que estão fora da diagonal principal da matriz.

Lillesand e Kiefer (1994) ressaltam ainda que ambas estatísticas devem ser utilizadas na avaliação de classificações, devendo-se considerar também outros aspectos. A qualidade de qualquer estimativa de exatidão está diretamente ligada à qualidade das informações utilizadas para estabelecer a "verdade terrestre" das áreas de teste, devendo-se portanto, quando possivel, incorporar à análise dos erros informações relacionados às diferenças de data dos produtos utilizados (dados auxiliares e imagem), estimativa do erro das localizações de pontos coletados, erro de registro da imagem, entre outros, para uma melhor avaliação final.

Segundo Guptill e Morrison (1995) o valor mínimo necessário para uma classificação ser aceitável é de $85 \%$, em relação a exatidão geral, do ponto de vista do usuário da classificação.

Outro aspecto importante relaciona-se ao direcionamento das análises de exatidão para as aplicações específicas dos produtos gerados, que devem ser analisados com critérios quanto a limitações e confiabilidade. 


\subsubsection{Manipulação de imagens}

Diversos processamentos podem ser empregados para ressaltar características das imagens ou reduzir a dimensionalidade dos dados originais. As principais técnicas aplicadas neste trabalho estão descritas nos itens seguintes.

\subsubsection{Razão de bandas}

Constitui em uma operação aritmética simples empregada em sensoriamento remoto para realçar diferenças espectrais (Crósta, 1992). Diversos indices de vegetação, concetrações minerais, entre outros, são gerados a partir de razões de banda.

Os processamentos para correção atmosférica devem ser realizados antes de se calcular uma razão de bandas, pois o espalhamento atmosférico afeta intensamente algumas bandas (principalmente na região do visível), sendo necessário o ajuste prévio das imagens para que a razão entre bandas represente efetivamente a diferença de reflectância entre os pixels.

A razão entre bandas produz uma imagem praticamente sem efeito topográfico (ausência do sombreamento topográfico). Esse tipo de produto pode ser utilizado como imagem de entrada nos procedimentos de classificação, minimizando a confusão do classificador nas áreas com sombra.

\subsubsection{2 Índice normalizado de diferença de vegetação (NDVI)}

O NDVI é um indice de vegetação amplamente utilizado que emprega as bandas 3 e 4 , relativas aos canais do vermelho $(0.63-0.69 \mu \mathrm{m})$ e infravermelho próximo $(0.76$ $0.90 \mu \mathrm{m})$ no satélite TM-landsat, conforme a equação seguinte:

$$
N D V I=\frac{T M 4-T M 3}{T M 4+T M 3}
$$

O NDVI é amplamente aplicado no monitoramento da cobertura vegetal, por apresentar uma estimativa de cobertura vegetal que compensa variaçōes de iluminação, declividade e direção do terreno, entre outros fatores que normalmente prejudicam as informações geradas por indices mais simples. 


\subsubsection{Análise por principais componentes}

A análise por principais componentes constitui um tratamento matemático que permite reunir a correlação entre o conjunto de imagens utilizado, permitindo quantificar a correlação existente e compactar os dados utilizando transformações matemáticas.

Crósta (1992) empregando o conceito de espaço de atributos ${ }^{8}$ define que a principal função dessa técnica é determinar a extensão da correlação entre bandas espectrais e, através de uma transformação matemática apropriada, removê-la.

A análise por principais componentes gera um número de "Principais Componentes (PCs)" igual ao número de bandas espectrais utilizadas. Cada PC representa uma porcentagem da variância total do conjunto, estando presente na primeira componente cerca de $80-90 \%$ da variância do conjunto, ou seja as informações que são correlacionadas em todas as bandas estarão reunidas na PC1. Essa imagem geralmente reúne as informações relativas ao sombreamento topográfico, estando a PC2 mais relacionada com as variações na cobertura vegetal e do solo, bastante útil nos processamentos de classificação.

${ }^{8}$ Espaço de atributos - constitui a dimensão espacial produzida ao se relacionar as informaçōes dos pixels das bandas espectrais (Crósta, 1992, pg.107). 


\subsection{Cálculo do modelo numérico de terreno (MNT)}

Os dados geralmente disponiveis para o cálculo do modelo numérico de terreno são: curvas de nível e pontos cotados. Alguns programas admitem também a entrada de dados adicionais como: linhas de quebra, descontinuidades, áreas planas, entre outras informações. A análise dos resultados obtidos no cálculo do modelo é feita, geralmente, comparando-se a qualidade dos contornos gerados pelo programa, sobre os dados do modelo calculado, e os dados de contorno utilizados como entrada.

As linhas de contorno no caso da geração de modelos de superfície representam isolinhas de elevação. A utilização do computador no processo de criação de um mapa de contorno usualmente envolve a construção de um modelo matemático da superfície que é processado antes da construção das linhas de contorno. Davis (1986) descreve as técnicas de geração de mapas de contorno ressaltando que os algoritmos utilizados pelo computador traçam as linhas de contorno baseando-se em um relacionamento matemático preciso estruturado na geometria dos dados de controle.

\subsubsection{Métodos de Interpolação}

Segundo Yamamoto (1998) os métodos de interpolação são baseados no ajuste de funções matemáticas ao conjunto de dados, e permitem interpolar ou estimar o valor da variável de interesse em um ponto não amostrado. As funções de interpolação podem ser subdivididas em duas classes:

- Funções globais;

- Funções locais;

As funções globais aproximam de uma única vez todos os pontos de dados do mapa, permitindo-se interpolar o valor da função em qualquer ponto dentro do domínio dos pontos de dados originais, sendo que a qualidade do resultado é alterada caso novos pontos sejam adicionados ou retirados, interferindo no domínio da função.

No caso das funções locais a retirada ou acréscimo de dados afetará somente os pontos mais próximos estimados, dentro de uma dada distância, não interferindo na estimativa das demais porçöes.

Quando se utilizam os métodos locais, deve-se definir para cada ponto a ser interpolado o subconjunto de $n$ pontos de dados da vizinhança próxima.

Existem, portanto, dois problemas na definição dessa vizinhança:

- o tamanho do subconjunto e,

- como os pontos do subconjunto devem ser escolhidos. 
Com relação ao tamanho do subconjunto, este não dever ser excessivamente pequeno (1 ou 2) e nem muito grande, pois relaciona-se à vizinhança local. Shepard (1968) segundo Yamamoto (1998) sugere no mínimo 4 e no máximo 10 pontos para cada subconjunto.

Com relação aos critérios para a seleção de pontos do subconjunto, estes podem ser subdivididos basicamente em dois grupos:

- Estruturado;

- Não estruturado;

No primeiro grupo, ao qual denomina-se estruturado, encontra-se o método da triangulação, que consiste na subdivisão da fronteira convexa ${ }^{9}$ em triângulos. Assim, a interpolação de um ponto qualquer é feita dentro do domínio da célula triangular a que pertence o mesmo, usando funções de interpolação específicas. A interpolação baseada na triangulação é feita sempre com um subconjunto de pontos de dados de tamanho fixo (igual a três vértices do triângulo).

No caso da triangulação o tamanho dos triângulos é inversamente proporcional à densidade de amostragem, ou seja, quanto maior o número de dados amostrados menores serão as dimensões dos triângulos gerados durante o processo de triangulação (Yamamoto, 1998).

No grupo não estruturado, os pontos de dados do subconjunto não estão ligados por qualquer estrutura espacial, ao contrário da triangulação. Dentro desse grupo podese ter os seguintes critérios para a seleção de pontos para o subconjunto:

- $n$ pontos mais próximos;

- $\quad n / 4$ pontos mais próximos por quadrante;

- $n / 8$ pontos mais próximos por octante;

O primeiro critério estabelece que cada ponto será interpolado com base no subconjunto de n pontos vizinhos mais próximos, independentemente da distribuição espacial dos pontos de dados. Este critério não proporciona uma boa amostragem espacial, especialmente quando há agrupamento de pontos.

Os dois últimos critérios denominados quadrante e octante, dividem a área em torno do ponto a ser interpolado em quatro ou oito setores, dentro dos quais são localizados $n / 4$ ou $n / 8$ pontos mais próximos, respectivamente.

Cada uma dessas funções de interpolação pode ser subdividida em interpoladores exatos e aproximados. Diz-se que a interpolação é exata quando o

\footnotetext{
${ }^{9}$ Fronteira convexa - Constitui o domínio da interpolação, que pode ser definido como um polígono convexo de área mínima que engloba os dados (Yamamoto, 1998).
} 
residuo (diferença entre o valor computado pela função de interpolação e o valor observado) é nulo e aproximada quando há resíduo.

\subsubsection{Métodos de interpolação mais utilizados em geologia}

\subsubsection{Métodos globais}

Segundo Yamamoto (1998) dentre os métodos globais destacam-se:

- Polinômios: utilizados para ajustes de superfícies ou hipersuperfícies de tendência, que foram extensivamente utilizados na década de 60 para estudos da variação espacial de parâmetros geológicos;

- Equações multiquádricas: propostas por Hardy (1971), pois os polinômios ou harmônicos de Fourier não apresentavam precisão suficiente para a representação de mapas de engenharia.

\subsubsection{Métodos locais}

Segundo Yamamoto (1998) existe um grande número de funções, das quais destacam-se:

- Interpolação linear em triângulos: utilizada quando é feita a triangulação dos pontos de dados. Esta é a opção mais simples para interpolação de dados em redes de triângulos; porém apresenta problemas de continuidade da superficie nos limites dos triângulos;

- Ponderação pelo inverso da potência da distância: é o método de uso comum em geologia, devido a sua facilidade de implementação. Contudo, apresenta problemas devido ao surgimento de áreas planas em torno dos pontos de dados;

- Funções de base radial: incluem-se, entre outras, a krigagem ordinária, multiquádricas e splines. Embora sejam agrupadas nesta classe, cada uma das funções de base radial proporcionam interpolações precisas e suaves entre os subconjuntos vizinhos.

\subsubsection{Técnica de ajuste de placas delgadas discretizadas (discretised thin plate spline technique)}

Hutchinson (1996) apresenta uma modificação na abordagem de interpolação para a geração de modelos por reticulação utilizando uma interpolação, que apresenta a eficiência computacional de um algoritmo empregando o método de interpolação pelo inverso da potência da distância, que é um método localmente ajustado, sem que a 
superfície gerada perca a continuidade, o que é obtido com os métodos de interpolação por Spline e Krigagem.

O método empregado pelo TOPOGRID é conhecido como uma técnica de ajuste de placas delgadas discretizadas (discretised thin plate spline technique) (Wahba, 1990), onde a rugosidade gerada é modificada para permitir o ajuste do MNT aos rios e quebras do relevo que estejam representadas pelo conjunto de dados utilizados na geração do modelo. Os rios devem ter o sentido orientado para o fluxo correto da drenagem.

Esse método permite a modelagem de processos hidrológicos, erosivos, etc, por que preserva a estrutura de drenagem do modelo e, ao mesmo tempo, remove desvios na representação do perfil de curvatura, que poderiam limitar as análises.

O programa ARC/INFO 7.2, utilizado para a geração modelo numérico de terreno, emprega a abordagem de Hutchinson (1996) que está implementada no módulo TOPOGRID, que é uma adaptação para o ARC/INFO do programa ANUDEM desenvolvido por M.F. Hutchinson no CRES (Centre for Resource and Environmental Studies) da Universidade Nacional da Austrália em Canberra, que atualmente (05/2002) está na versão 4.6.3 (comercial).

Yamamoto (1996) em um estudo comparativo de interpolação de dados de relevo, demonstra que os melhores resultados em termos de ajuste à base original foram obtidos com o uso da técnica spline de placa delgada (TPS - thin plate spline).

A Figura 6.12 apresenta a comparação entre os métodos de interpolação descritos e o resultado obtido pelo processo manual, utilizando dados de exemplo apresentados por Davis (1986), onde visualmente também é possível notar a melhor qualidade do modelo gerado pelo TOPOGRID, que é uma adaptação da técnica de interpolação por TPS. A Figura 6.13 apresenta a comparação entre o mapa de contorno gerado com o modelo interpolado por TPS (TOPOGRID) para um recorte da área de trabalho e os dados de entrada.

Outra técnica que é considerada uma evolução da TPS è a interpolação descrita por Mitasova e Mitas (1993) que utilizam funções denominadas splines completamente regularizadas (CRS - completely regularized splines), derivadas da formulação original do TPS (Silva, 1999). Essa técnica está implementada no comando s.surf.tps do pacote GRASS, que também permite o cálculo direto dos gradientes e curvatura, fornecendo segundo Silva (1999), indices morfométricos mais acurados dos que os obtidos por rotinas baseadas nas matrizes interpoladas.

A técnica CRS não foi utilizada neste trabalho devido a necessidade de migração dos dados para outro sistema (GRASS), o que fugiria do escopo do trabalho, 
contudo os bons resultados obtidos com a utilização da técnica TPS favorecem o teste e utilização de rotinas semelhantes, devendo-se verificar se o modelo gerado com a técnica CRS também é hidrologicamente correto.

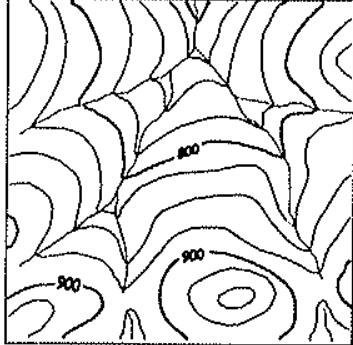

(a)

Processo Manual

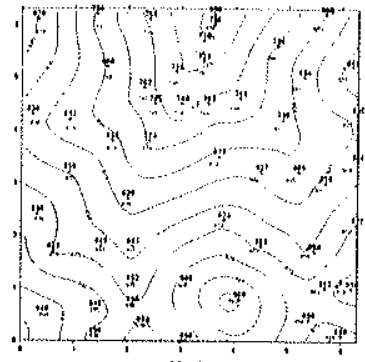

(b)

TPS - (TOPOGRID)

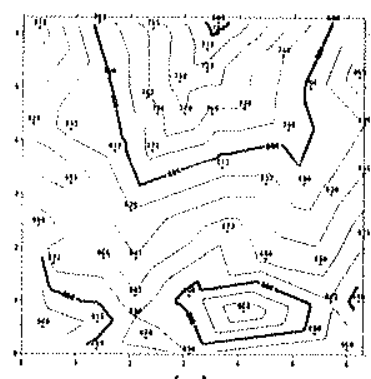

(c)

Triangulação linear (Surfer)

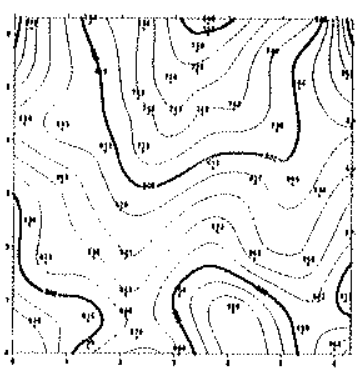

(d)

Minima Curvatura (Surfer)

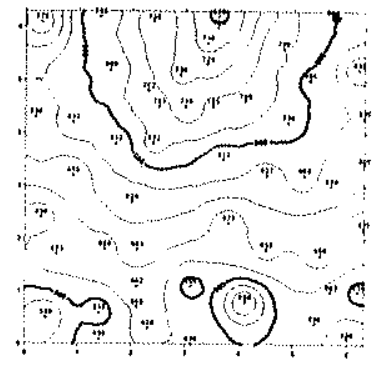

(e)

Inverso do Quadrado da Distanncia (Surfer)

Figura 6.12 - Comparação entre o produto gerado pelo processo manual (a) e demais algoritmos.

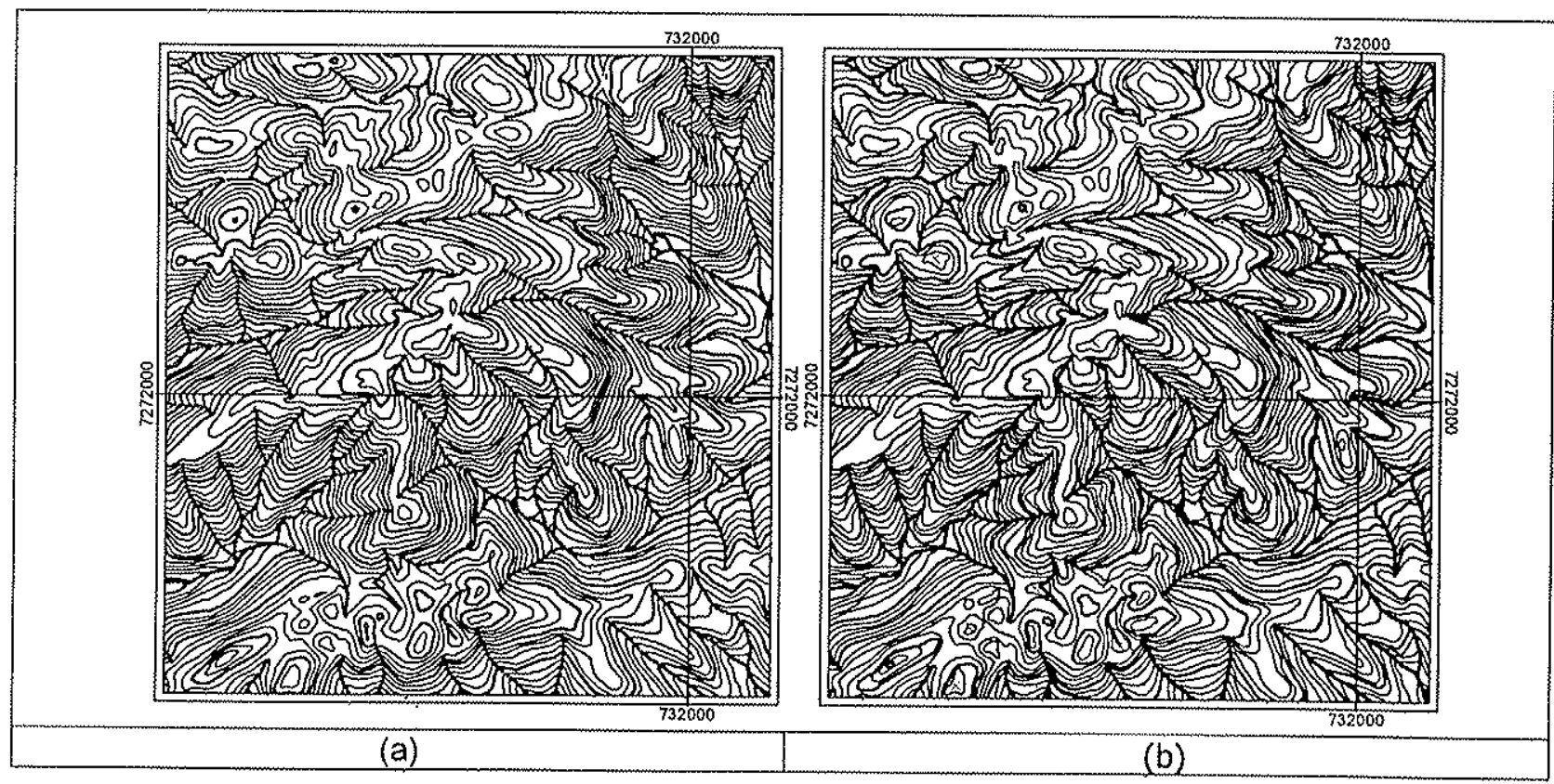

Figura 6.13 - Comparação entre o mapa de contorno gerado com o modelo interpolado por TPS (TOPOGRID) (a); e dados de entrada (curvas de nível, pontos cotados e drenagens) (b). 


\subsection{Cálculo de declividade}

O cálculo da declividade emprega a função $S L O P E$ disponivel no módulo GRID do $A R C / I N F O$ 7.2.1. Essa função identifica a taxa máxima de mudança nos valores de uma célula para os seus vizinhos. O programa pode calcular a imagem de saída em unidade de porcentagem ou graus, empregando as seguintes funçōes:

$$
\begin{gathered}
\frac{\text { Altura }}{\text { Distáncia }}=\sqrt{\left(\frac{d z}{d x}\right)^{2}+\left(\frac{d z}{d y}\right)^{2}} \\
\text { Declividade(graus) }=a \tan \times\left(\frac{\text { Altura }}{\text { Distância }}\right) \times 57.29578
\end{gathered}
$$

Onde:

atan $=$ arco-tangente

$\left(\frac{d z}{d x}\right)=\frac{((a+2 d+g)-(c+2 f+i))}{8 \times \text { espaçamento_malha }(X)}$

$\left(\frac{d z}{d y}\right)=\frac{((a+2 b+c)-(g+2 h+i))}{8 \times \text { espaçamento_malha(Y)}}$ os deltas são calculados utilizando uma janela móvel de $3 \times 3$ :

$a$ até i representam os valores de $Z$ na janela:

\begin{tabular}{|c|c|c|}
\hline$a$ & $b$ & $c$ \\
\hline$d$ & $e$ & $f$ \\
\hline$g$ & $h$ & $i$ \\
\hline
\end{tabular}

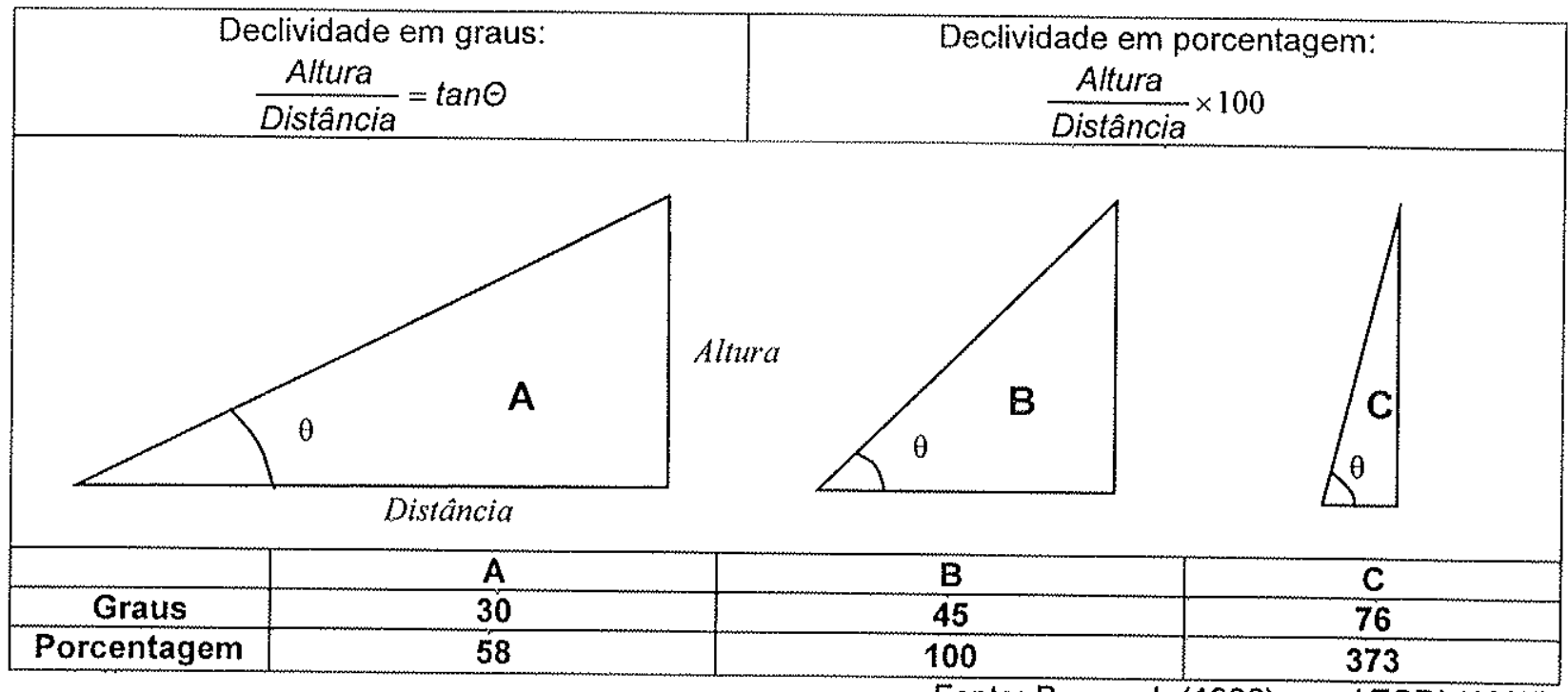

Fonte: Burrough (1986) apud ESRI (1997).

Figura 6.14 - Exemplos de rampas com valores de declividade cálculados em unidades de grau e porcentagem.

A função ajusta um plano aos valores de $Z$ de um conjunto de $3 \times 3$ células ao redor da célula central que está sendo processada. A direção do declive que o plano apresenta é o aspecto da célula em processamento. A declividade para cada célula é calculada a partir das $3 \times 3$ células vizinhas utilizando a técnica de média máxima. Caso exista uma célula na vizinhança sem dados, o valor $Z$ do centro da célula em processamento será atribuído àquele ponto. 


\section{CAPÍTULO 7- APRESENTAÇÃO E DISCUSSÃO DOS RESULTADOS}

\subsection{Sensoriamento remoto}

A análise das imagens do satélite Landsat 7 - ETM+ envolveu as etapas de préprocessamento e processamento de dados descritas no capítulo 3 . Os resultados de cada etapa são apresentados nos itens seguintes.

\subsubsection{Correção atmosférica}

Os valores obtidos na análise dos histogramas da imagem correspondente a cena 220-077 (21-04-2000) e recorte da área relativa ao municipio são apresentados na Tabela 7.1. Pode-se considerar, para a cena, o modelo relativo de espalhamento em uma situação de condições atmosféricas muito limpa, conforme detalhado no capitulo 3, item 3.1.2, pois o valor inicial da bruma (SHV - Start Haze Value), para a banda TM1 é inferior a 55, conforme mostra a Tabela 7.1 .

Tabela 7.1- Porção inferior do histograma de freqüências para a cena 220-77 (21-042000 ), os valores de $D N$ estão destacados e representam as quebras de continuidade nas freqüências de valores para cada banda indicada nas colunas.

\begin{tabular}{|c|c|c|c|c|c|c|}
\hline \multirow{2}{*}{ Valor do $D N$} & \multicolumn{6}{|c|}{ Número de pixels (freqüéncia) em cada banda } \\
\hline & TM1 & TM2 & TM3 & TM4 & TM5 & TM7 \\
\hline 1 & 0 & 2 & 3 & 1 & 5 & 9 \\
\hline 2 & 1 & 1 & 3 & 3 & 16 & 26 \\
\hline 3 & 3 & 0 & 10 & 5 & 30 & 42 \\
\hline 4 & 1 & 1 & 5 & 4 & 53 & 182 \\
\hline 5 & 1 & 2 & 13 & 5 & 111 & 2637 \\
\hline 6 & 0 & 2 & 15 & 10 & 1174 & 32814 \\
\hline 7 & 0 & 1 & 8 & 14 & 49822 & 235721 \\
\hline 8 & 1 & 2 & 16 & 19 & 528592 & 765357 \\
\hline 9 & 0 & 1 & 24 & 38 & 1154185 & 1062726 \\
\hline 10 & 0 & 3 & 29 & 6593 & 857360 & 698075 \\
\hline 11 & 1 & 3 & 20 & 278003 & 264798 & 309839 \\
\hline 12 & 0 & 1 & 36 & 1133326 & 55159 & 229821 \\
\hline 13 & 0 & 4 & 43 & 967431 & 29831 & 317250 \\
\hline 14 & 2 & 4 & 56 & 281712 & 29588 & 493492 \\
\hline 15 & 0 & 4 & 185 & 74828 & 32512 & 733922 \\
\hline 16 & 0 & 7 & 1600 & 33626 & 35348 & 962219 \\
\hline$\vdots$ & $\vdots$ & $\vdots$ & $\vdots$ & $\vdots$ & $\vdots$ & $\vdots$ \\
\hline 20 & 2 & 10 & 787013 & 14903 & 56744 & 1584934 \\
\hline 21 & 5 & 23 & 1408017 & 12528 & 65211 & 1750619 \\
\hline 22 & 4 & 20 & 1989402 & 10872 & 75420 & 1921508 \\
\hline 23 & 4 & 117 & 2795000 & 10080 & 88410 & 1945507 \\
\hline 24 & 3 & 956 & 3805716 & 9734 & 102697 & 1854642 \\
\hline$\dot{I}^{\prime}$ & $\vdots$ & $\vdots$ & $\vdots$ & $\vdots$ & $\vdots$ & $\vdots$ \\
\hline 38 & 31 & 2124039 & 527066 & 19720 & 496456 & 404432 \\
\hline 39 & 49 & 1621023 & 489743 & 20440 & 533377 & 374378 \\
\hline 40 & 57 & 1345165 & 455063 & 21532 & 575320 & 343303 \\
\hline 41 & 235 & 1182391 & 421253 & 23128 & 619718 & 313633 \\
\hline
\end{tabular}


A banda TM2 foi escolhida como referência para a correção dos dados, pois entre as bandas relativas à porção do espectro visível, é a que apresenta uma distinção mais clara no aumento do número de pixels existentes na porção menor do histograma, associado a uma pequena freqüência de valores (número de pixels), abaixo do limite determinado, não ocorrendo praticamente perda de informação.

A Tabela 7.2 apresenta os valores calculados segundo o método de Chavez (1989), que pode utilizar como referência qualquer uma das 3 bandas do espectro visivel para o ajuste dos valores a serem corrigidos. Inicialmente, segundo um ajuste ao espalhamento relativo, e posteriormente, a correção dos valores obtidos em relação às perdas e ganhos médios dos sensores de cada banda (disponiveis para a imagem utilizada).

Tabela 7.2 - Valores iniciais de ajuste atmosférico (pelo método do histograma) utilizando a banda TM2 para a definição do valor de correção de referência (SHV="Start Haze Value"), conforme a técnica de Chavez (1989).

\begin{tabular}{|c|c|c|c|}
\hline $\begin{array}{c}\text { Valor } \\
\text { referência } \\
\text { TM2 } \\
\text { (SHV=22) }\end{array}$ & $\begin{array}{c}\text { Valores obtidos pelo } \\
\text { método do } \\
\text { Histograma Mínimo }\end{array}$ & $\begin{array}{c}\text { Valores de ajuste (inicial) para a } \\
\text { cena: Método de correção } \\
\text { espalhamento simples }\end{array}$ & $\begin{array}{c}\text { Valores corrigidos: } \\
\text { Ajuste perda/ganho } \\
\text { dos sensores. }\end{array}$ \\
\hline TM1 & 40 & 42,0 & 41,4 \\
\hline TM2 & 22 & 22,0 & 22,8 \\
\hline TM 3 & 14 & 12,2 & 10,2 \\
\hline TM 4 & 9 & 4,7 & 4,4 \\
\hline TM 5 & 4 & 0,3 & 0,2 \\
\hline TM 6 & 1 & 0,1 & 1,0 \\
\hline
\end{tabular}

Deve-se destacar que os valores obtidos com a análise do histograma para valor inicial de correção (SHV) para a banda TM1 também apresentaram uma distinção aceitável do aumento do número de pixels, contudo a imagem apresenta qualidade significativamente inferior em relação às bandas TM2 e TM3. O pouco contraste observado na imagem TM1, associado com a presença de pequena quantidade de "stripping", indica que ocorreu maior interferência atmosférica nos sensores dessa banda espectral durante 0 imageamento do satélite Landsat 7. Esse fator provavelmente ocasionou um desbalanceamento no processo de calibração da radiância interna, conforme descrito no capítulo 3 .

A Figura 7.1 apresenta o resultado da aplicação do procedimento de correção atmosférica (método espalhamento simples corrigido), comparando com uma mesma composição sem correção. Em ambas imagens aplicou-se o aumento linear de contraste com corte de $0,1 \%$ dos extremos dos histogramas. 


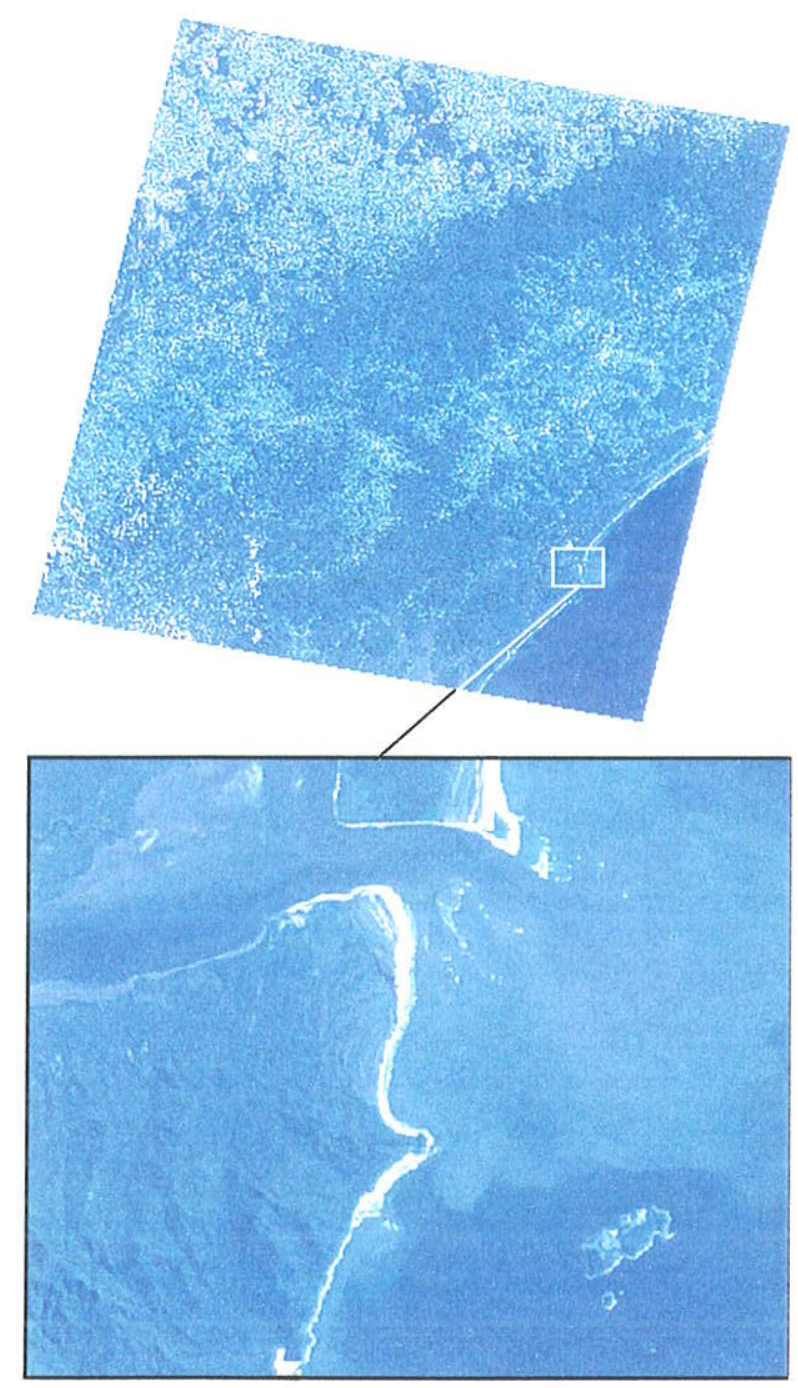

(a)

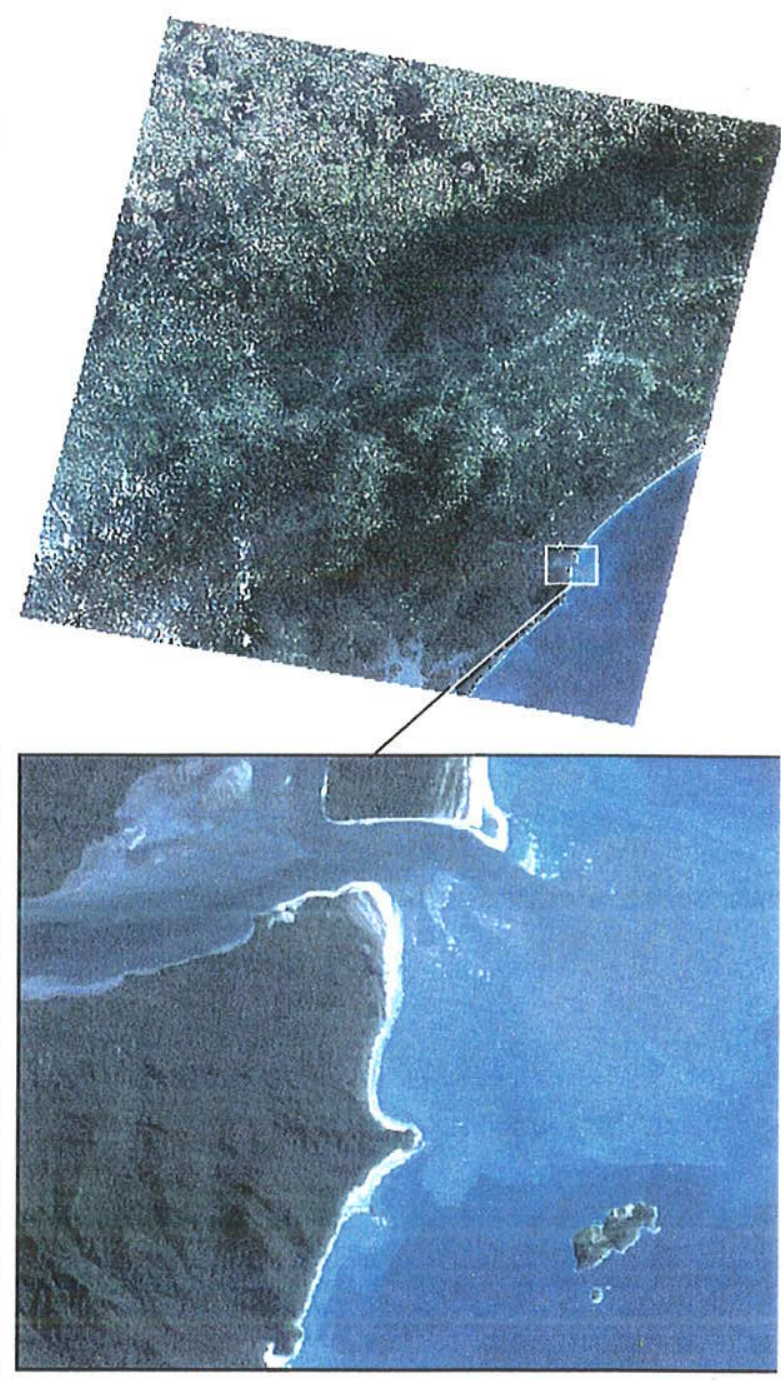

(b)

Figura 7.1 - Composição colorida relativa a faixa espectral do visível (3R2G1B). Detalhes: (a) antes da aplicação da correção atmosférica; (b) após aplicação da correção atmosférica, com o mesmo ajuste linear de contraste.

\subsubsection{Correção geométrica}

Utilizando-se do programa E.R. Mapper 5.5 as imagens foram devidamente georreferenciadas à base cartográfica, na qual foram coletados 47 pontos de controle, devidamente distribuídos por toda a área do município. A Tabela 7.3 apresenta os dados utilizados e o RMS (Root Means Square), que representa uma medida média do erro associado a localização definida para cada ponto de controle. O erro quadrático médio obtido para o processo de georreferenciamento foi de 0.69 , o que corresponde a aproximadamente 20 metros, coerente com as dimensões dos pixels ( $30 \times 30 \mathrm{~m})$. 
Tabela 7.3 - Listagem dos pontos de controle para o georreferenciamento da imagem, seguidos do erro quadrático médio (RMS), para cada ponto. O RMS médio indica um erro médio de aproximadamente 20 metros para o gerreferenciamento.

\begin{tabular}{|c|c|c|c|c|c|}
\hline Point & Célula-X & Célula-Y & Para-X & Para-Y & RMS \\
\hline 1 & 4000,736 & 3865,089 & 763390,4 & 7280395 & 1,4433 \\
\hline 2 & 3986,988 & 3876,939 & 762978,3 & 7280040 & 1,1946 \\
\hline 3 & 4063,02 & 3997,955 & 765256,2 & 7276411 & 0,7718 \\
\hline 4 & 4104,814 & 3991,475 & 766508,7 & 7276605 & 0,7142 \\
\hline 5 & 3594,278 & 3801,179 & 751210,1 & 7282310 & 1,581 \\
\hline 6 & 2672,292 & 2805,704 & 723585,3 & 7312162 & 0,3291 \\
\hline 7 & 3481,054 & 4400,517 & 747814,1 & 7264335 & 0,6699 \\
\hline 8 & 3567,909 & 3823,813 & 750419,8 & 7281631 & 0,4466 \\
\hline 9 & 3551,863 & 3834,944 & 749938,9 & 7281298 & 1,0778 \\
\hline 10 & 3487,431 & 3864,257 & 748007,8 & 7280418 & 1,2746 \\
\hline 11 & 3455,509 & 3861,418 & 747051,2 & 7280503 & 0,2657 \\
\hline 12 & 3440,777 & 3963,704 & 746609,2 & 7277436 & 1,139 \\
\hline 13 & 3350,905 & 3921,975 & 743916,2 & 7278687 & 0,4658 \\
\hline 14 & 3352,957 & 3923,547 & 743977,7 & 7278640 & 0,8544 \\
\hline 15 & 3334,141 & 3952,287 & 743413,7 & 7277778 & 0,8072 \\
\hline 16 & 3061,36 & 4237,237 & 735237,6 & 7269231 & 0,7315 \\
\hline 17 & 3154,735 & 4142,943 & 738036,3 & 7272059 & 0,7985 \\
\hline 18 & 2605,542 & 4247,766 & 721577,8 & 7268913 & 0,5517 \\
\hline 19 & 2904,212 & 3665,151 & 730531,1 & 7286387 & 0,5182 \\
\hline 20 & 2878,614 & 3680,683 & 729763,9 & 7285921 & 0,3752 \\
\hline 21 & 3393,829 & 4224,552 & 745201 & 7269612 & 0,4243 \\
\hline 22 & 3387,102 & 4229,129 & 744999,4 & 7269475 & 1,0499 \\
\hline 23 & 3404,7 & 4214,161 & 745526,8 & 7269924 & 0,7949 \\
\hline 24 & 3420,529 & 4194,506 & 746001,3 & 7270514 & 0,4701 \\
\hline 25 & 3437,784 & 4186,485 & 746518,4 & 7270754 & 0,0381 \\
\hline 26 & 3471,588 & 4115,144 & 747531,8 & 7272894 & 0,3163 \\
\hline 27 & 3296,582 & 3968,559 & 742288 & 7277289 & 0,3504 \\
\hline 28 & 3222,52 & 3907,39 & 740068,9 & 7279124 & 0,7663 \\
\hline 29 & 3365,912 & 3819,946 & 744366,4 & 7281747 & 0,7131 \\
\hline 30 & 3179,975 & 3230,667 & 738797,3 & 7299419 & 0,6502 \\
\hline 31 & 3072,934 & 3318,674 & 735589 & 7296779 & 1,2974 \\
\hline 32 & 2956,8 & 3397,308 & 732108,4 & 7294420 & 0,7586 \\
\hline 33 & 3205,083 & 3181,879 & 739549,9 & 7300882 & 0,3839 \\
\hline 34 & 3260,205 & 3028,896 & 741202,6 & 7305470 & 1,1775 \\
\hline 35 & 3219,398 & 2709,879 & 739981,2 & 7315038 & 1.1759 \\
\hline 36 & 3535,17 & 2819,688 & 749443,6 & 7311745 & 0,2254 \\
\hline 37 & 3530,267 & 4441,303 & 749288,7 & 7263112 & 0,7172 \\
\hline 38 & 3545,418 & 4335,461 & 749743,2 & 7266287 & 0,4092 \\
\hline 39 & 3656,643 & 4484,495 & 753075,6 & 7261818 & 0,8997 \\
\hline 40 & 3786,013 & 4461,396 & 756952,7 & 7262511 & 0,2385 \\
\hline 41 & 4075,997 & 4331,055 & 765643,5 & 7266421 & 0,8234 \\
\hline 42 & 4185,01 & 4298,169 & 768910,5 & 7267407 & 0,1498 \\
\hline 43 & 3980,299 & 2739,948 & 762783,5 & 7314138 & 0,7522 \\
\hline 44 & 4151,307 & 2722,145 & 767908,3 & 7314673 & 0,3602 \\
\hline 45 & 3745,475 & 3768,017 & 755741,3 & 7283305 & 0,2 \\
\hline 46 & 3646,618 & 3788,715 & 752778,7 & 7282684 & 0,1801 \\
\hline 47 & 2896,434 & 2973,849 & 730301,4 & 7307120 & 1,082 \\
\hline
\end{tabular}




\subsubsection{Classificação}

A classificação dos dados utilizou a técnica não supervisionada, empregando o algoritmo ISOCLASS do E.R. Mapper 5.5. Essa técnica permite ao analista classificar os dados em um número elevado de classes em uma primeira etapa, para posteriormente reclassificá-las em um número de classes de interesse à análise em questão. A Tabela 7.4 apresenta os valores utilizados para a classificação final apresentada na Figura 7.2.

Tabela 7.4 - Valores empregados na classificaçăo ISOCLASS no programa ER Mapper 5.5.

\begin{tabular}{|c|c|c|}
\hline \multicolumn{3}{|c|}{ ISOCLASS (ER Mapper 5.5) } \\
\hline Parâmetros & $\begin{array}{c}\text { Valores } \\
\text { utilizados }\end{array}$ & $\begin{array}{c}\text { Valores sugeridos pelo } \\
\text { programa }\end{array}$ \\
\hline Auto geração de classes & 16 classes & - \\
\hline Máximo número de classes & 16 & $-9,0 \%$ \\
\hline Porcentagem de pixels näo modificada entre interações & $99,5 \%$ & $0,01 \%$ \\
\hline Mínima porcentagem de membros na classe & $1,0 \%$ & $4,5(4,5-7,0)$ \\
\hline Máximo desvio padrão & 5,0 & $3,2(3,2-9,0)$ \\
\hline Minima diståncia entre as médias de cada classe & 3,0 & \\
\hline
\end{tabular}

No caso do municipio de Iporanga foram testados vários limiares de desvio padrão e distância mínima entre as classes, ocorrendo grande variação no tempo de execução da classificação, principalmente com o aumento da distância mínima entre as classes.

A utilização de valores crescentes de distância mínima entre as classes empregou um número excessivo de interações que pulam de 12-54 iterações, para valores de 2815 iterações para valores de distância mínima acima de 3,8, sem chegar ao limite de mudanças entre iterações de $99,5 \%$.

Os valores foram testados e modificados, em função dos resultados obtidos, visando a obtenção de uma separação mais clara possivel entre tipos de cobertura vegetal mais densos e menos densos que foram classificados conforme a Tabela 7.5.

Tabela 7.5- Classes definidas em função dos resultados obtidos na classificação não supervisionada ISOCLASS.

\begin{tabular}{|c|c|}
\hline C1 & Rios e corpos d' água \\
\hline C2 & $\begin{array}{c}\text { Vegetação de porte arbustivo (podendo incluir fragmentos de capoeira ou campo sujo, porte } \\
\text { arbustivo homogeneo) }\end{array}$ \\
\hline C3 & Vegetação de porte arbóreo (densa) associada (ou não) às encostas \\
\hline C4 & Solo exposto ou campo limpo (estradas e arruamentos) \\
\hline C5 & Campo sujo ou capoeira (porte arbustivo de individuos em padrão heterogêneo esparso) \\
\hline
\end{tabular}

O resultado da classificação é apresentado na Figura 7.2, seguindo as classes definidas na Tabela 7.5 . 


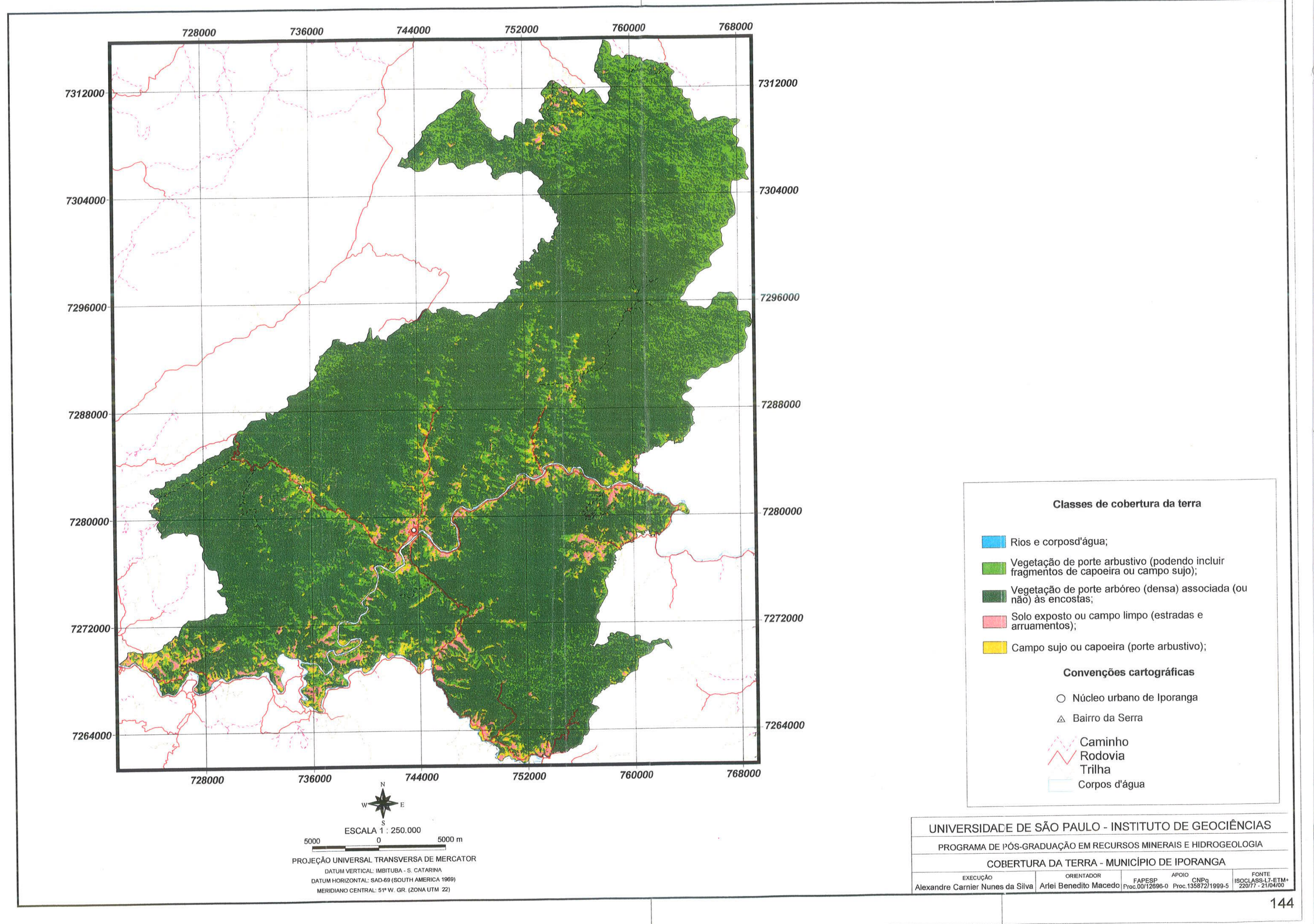




\subsubsection{Avaliação da classificação}

A avaliação da classificação utilizou os 156 pontos de campo. Foram adicionados 23 pontos que complementaram as informações obtidas em campo para áreas vizinhas dos pontos, totalizando 179 observações sobre a imagem classificada. O relatório de classificação é apresentado na Tabela 7.6.

Tabela 7.6- Relatório de avaliação da classificação.

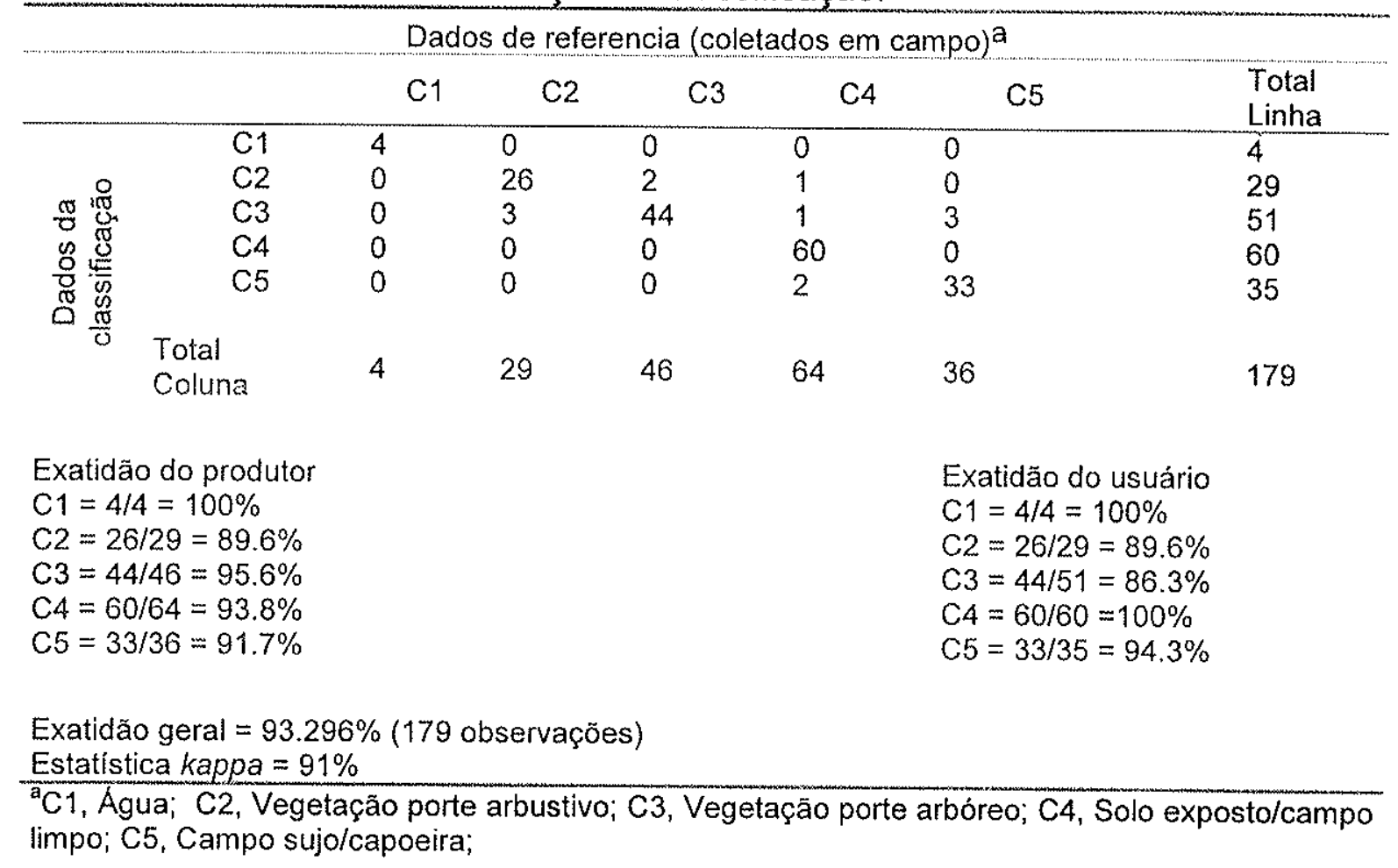

As Figuras 7.3 e 7.4 apresentam o comportamento estatístico das classes geradas, em relação às bandas originais do Landsat 7 e ao conjunto das imagens derivadas utilizadas na classificação. A observação do desvio padrão, representado pelas linhas de cor verde nos gráficos da segunda coluna, indicam um desvio padrão acima e abaixo da média, permitindo uma melhor caracterização das classes

A Figura 7.5 apresenta a comparação entre as fotografias aéreas da área e as classificações geradas: com 16 classes e classificação final com 5 classes.

A escolha do conjunto de imagens derivadas, utilizadas na classificação, seguiu parcialmente a sistemática descrita em Siqueira (1999). Essa autora utilizou a classificação não supervisionada para a separação de áreas vegetadas e não vegetadas em uma área de relevo movimentado. Tendo empregado, principalmente, índices (razões de bandas) e análise por componentes principais (PCA), com o objetivo de minimizar os efeitos do relevo na classificação.

A Tabela 7.7 descreve os cálculos para as imagens derivadas que foram utilizadas na classificação não supervisionada. 
Definiça des classes:

C1 - Rios a corpos d'agua;

C2 - Vegetaça de porte arbustivo (capoeira, cempo sujo)

C3 - Vegetaça de porte arbóroo (densa) associada às encostas:

CA - Solo exposto ou campo limpo (estredas a arruamentos):

C5 - Campo sujo ou capoeira (porte arbustivo):
Bandas originais

$1-\mathrm{B} 1$ :

2- B2;

3- B3:

4 - 84:

$5-B 5$ :

$6-87:$
Histogramas

C1

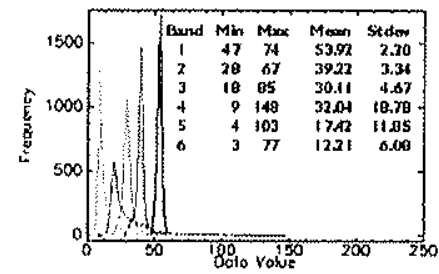

C2.

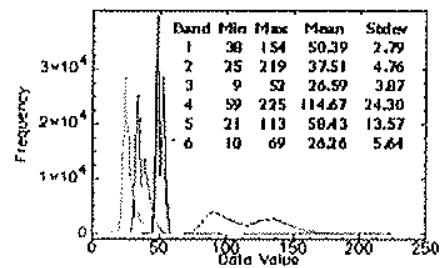

MínimoMáximo/Médiø

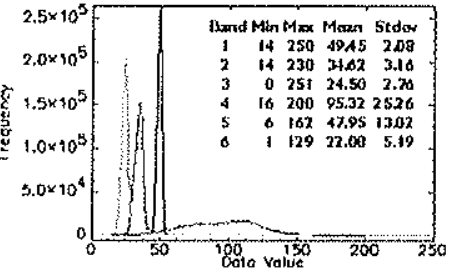

C4

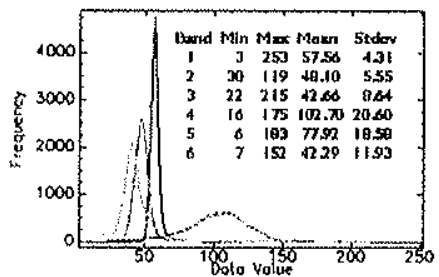

C5

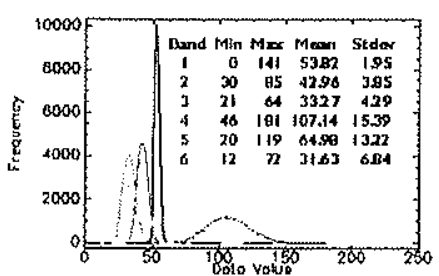

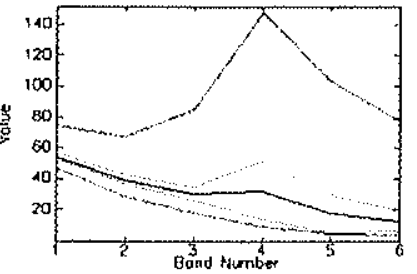
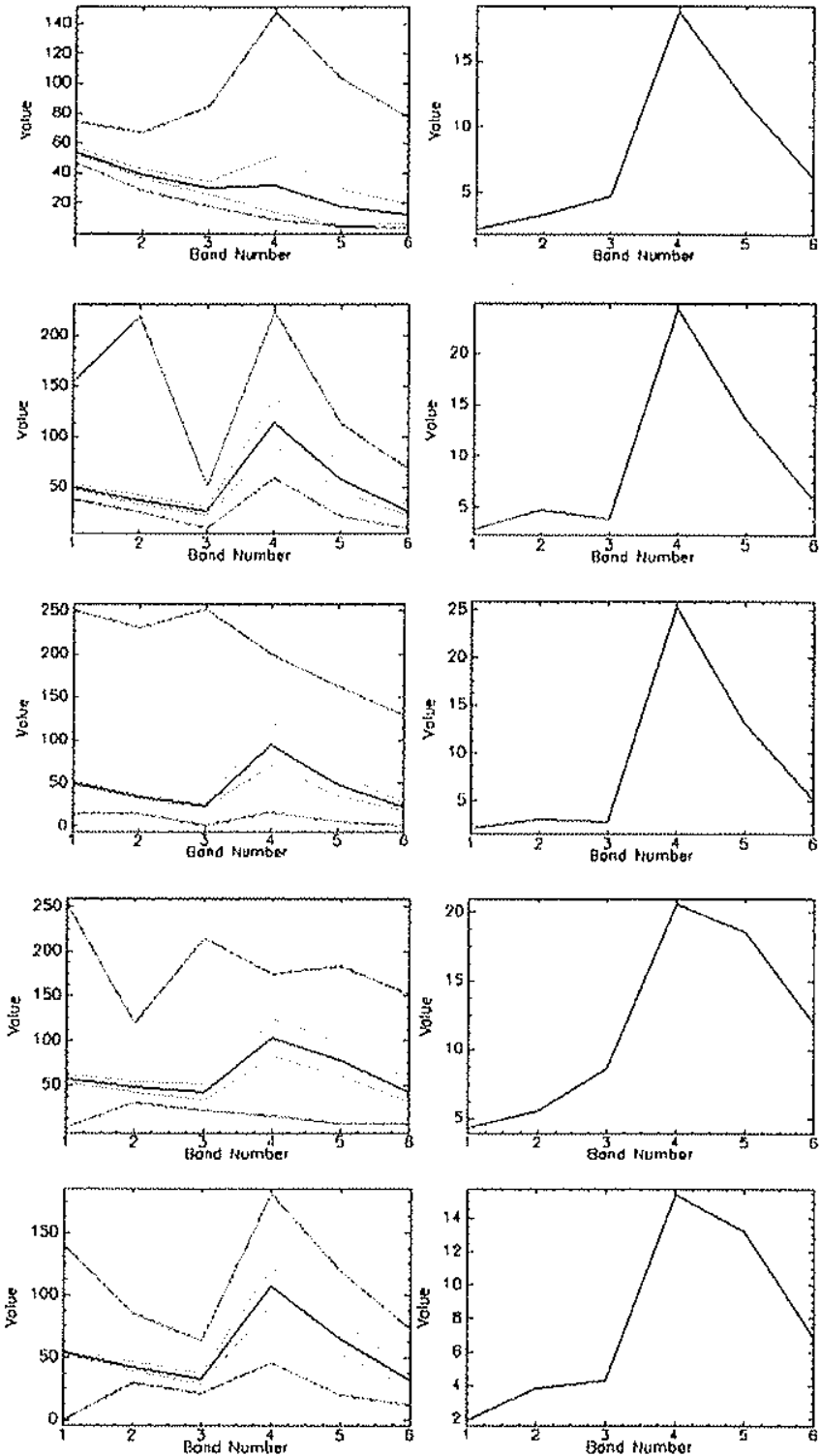

Figura 7.3 -Síntese estatística das classes geradas em relação às bandas originais. 
Definiçáo das classes:

C1 - Rios e corpos d' água:

C2 - Vegetaçáo de porte arbustivo (capoeira, campo sujo):

C3 - Vegetaçáo de porte arbóreo (densa) associada às encostas:

C4 - Solo exposto ou campo limpo (estradas e arruamentos):

C5 - Campo sujo ou capoeira (porte arbustivo):
Bandas utilizadas

1 - Razáo B1"B2*B3 / B3*B4*B5*(-1):

2 - NDVI;

3 - B4/B3 (com filtro de mediana $3 \times 3$ ):

4 - B5 (com filtro de mediana $3 \times 3$ ):

5 - B7 (com filtro de mediana $3 \times 3$ ):
Histogramas

C1

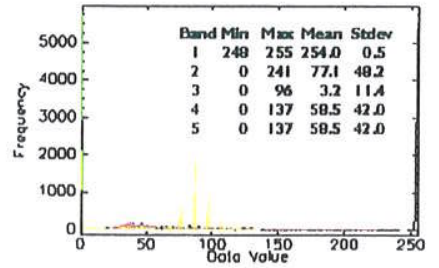

C2

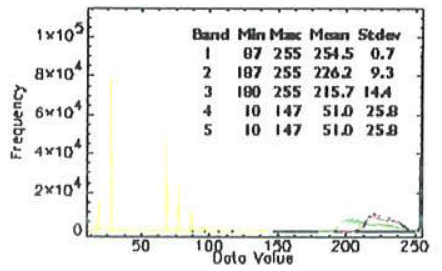

C3
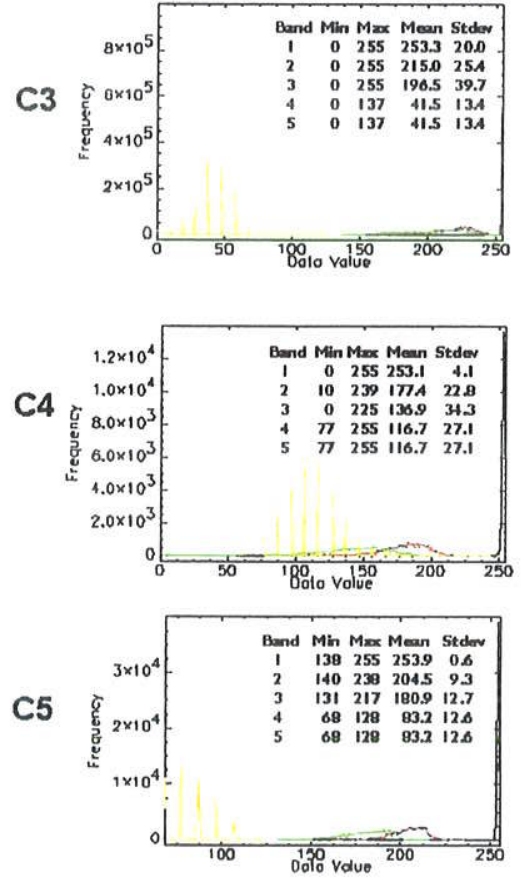

MinimoMáximo/Média
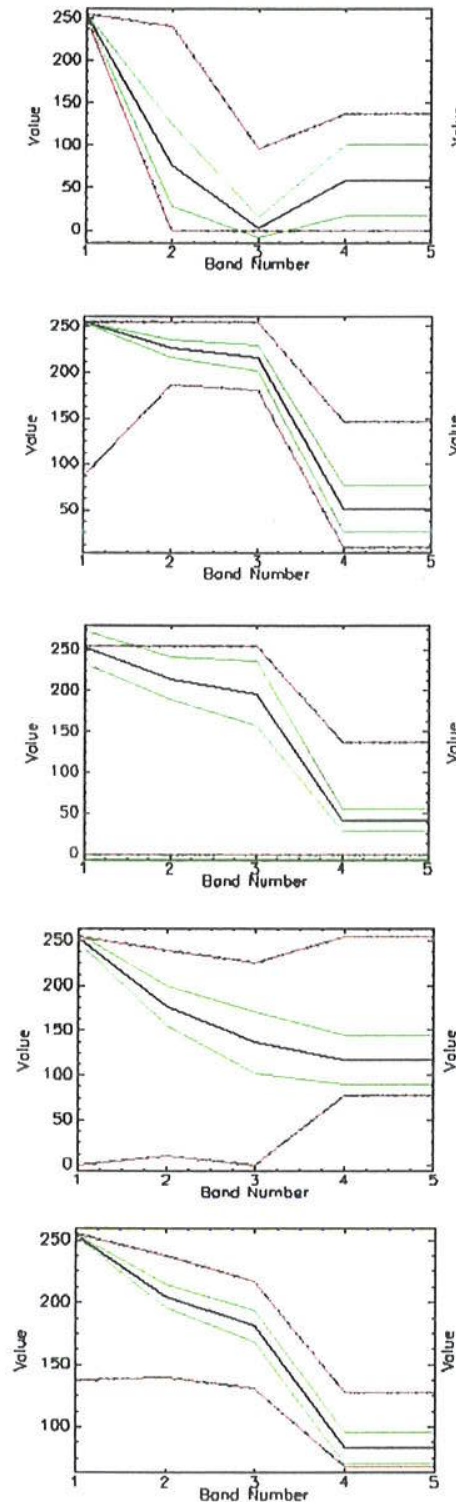

Desvio padrăo
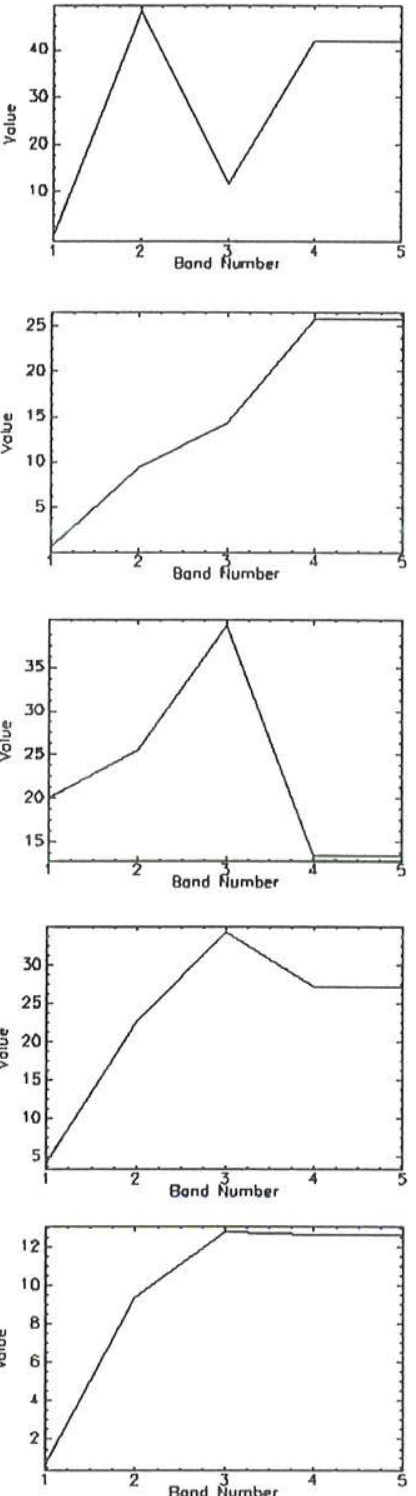

Figura 7.4 -Síntese estatística das classes geradas em relação às bandas derivadas. 
Outras composições foram testadas, incluindo PCs $(2,3$ e 4$)$ e razões entre as bandas $5,4,3$ e 2 . As que permitiram uma melhor distinção entre os alvos de interesse foram as divisões entre as bandas 4 e 3, e o cálculo do índice normalizado de diferença de vegetação (NDVI). As imagens dos principais componentes 2 e 3 apresentaram o efeito da topografia, prejudicando a classificação das áreas sombreadas que eram parcialmente classificadas como água nas porções mais sombreadas.

$\mathrm{Na}$ tentativa de minimizar esse efeito, utilizou-se a divisão dos produtos de um conjunto de bandas, resultando na imagem 11 descrita na Tabela 7.7. Entendendo que - produto das bandas ressaltaria as semelhanças, no caso, associando as respostas da água na faixa do espectro visivel (1, 2 e 3) e infravermelho próximo (4 e 5), e a subseqüente divisão ressaltaria as diferenças entre cada resposta.

A imagem gerada permitiu uma melhoria significativa na classificação da classe "água" na imagem, contudo, uma pequena parte das áreas de sombra ainda estavam sendo classificadas como "água", ao invés de "vegetação arbórea", como observado na imagem e em fotografias áreas.

Essas áreas foram então atribuídas à classe vegetação arbórea (C2), utilizandose o critério de distância dos corpos d'água, ou seja, áreas classificadas como "água" e localizadas em uma distância maior do que 30 metros dos corpos d'água, foram reclassificadas para a classe $\mathrm{C} 2$.

A utilização do filtro de mediana nas imagens 13 a 15 justifica-se pela melhor definição dos limites entre as classes e homogeneização nas áreas identificadas para cada classe (Tabela 7.7). A classificação em 16 classes, em uma primeira etapa e sua posterior reclassificação em 5 classes, resultaram em uma boa aproximação dos limites entre os tipos de cobertura da terra, conforme pode ser observado na Figura 7.5. A Figura 7.6 também apresenta também algumas das fotografias dos pontos de campo, que representam os tipos de coberturas determinados na classificação.

Tabela 7.7- Imagens derivadas utilizadas na classificação não supervisionada dos dados.

\begin{tabular}{|c|c|l|}
\hline Imagens & Cálculos & \multicolumn{1}{c|}{ Características da imagem } \\
\hline 11 & $\frac{B 1 \times B 2 \times B 3}{B 3 \times B 4 \times B 5} \times-1$ & $\begin{array}{l}\text {-efeito da topografia minimo; } \\
\text {-ressalta diferenças entre os tipos de cobertura } \\
\text {-presença de ruído (devido a banda 1); }\end{array}$ \\
\hline 12 & $N D V I=\frac{B 4-B 3}{B 4+B 3}$ & $\begin{array}{l}\text {-ressalta as caracteristicas dos tipos de cobertura vegetal; } \\
\text { áreas de campo e solo exposto; } \\
\text {-efeito topográfico parcialmente presente; }\end{array}$ \\
\hline 13 & $\frac{B 4}{B 3}[$ Filtro_mediana -3X3] & $\begin{array}{l}\text {-sem efeito topográfico; } \\
\text {-destaca as diferenças entre os tipos de cobertura; } \\
\text {-o filtro de mediana melhora a definição dos limites entre as } \\
\text { classes e a definiçáo das áreas de cada classe; }\end{array}$ \\
\hline 14 & $B 5[$ Filtro_mediana $-3 X 3]$ & -Ressalta as áreas com cobertura vegetal arbórea; \\
\hline 15 & $B 7[$ Filtro_mediana $-3 X 3]$ & -Ressalta as áreas de uso antrópico; \\
\hline
\end{tabular}




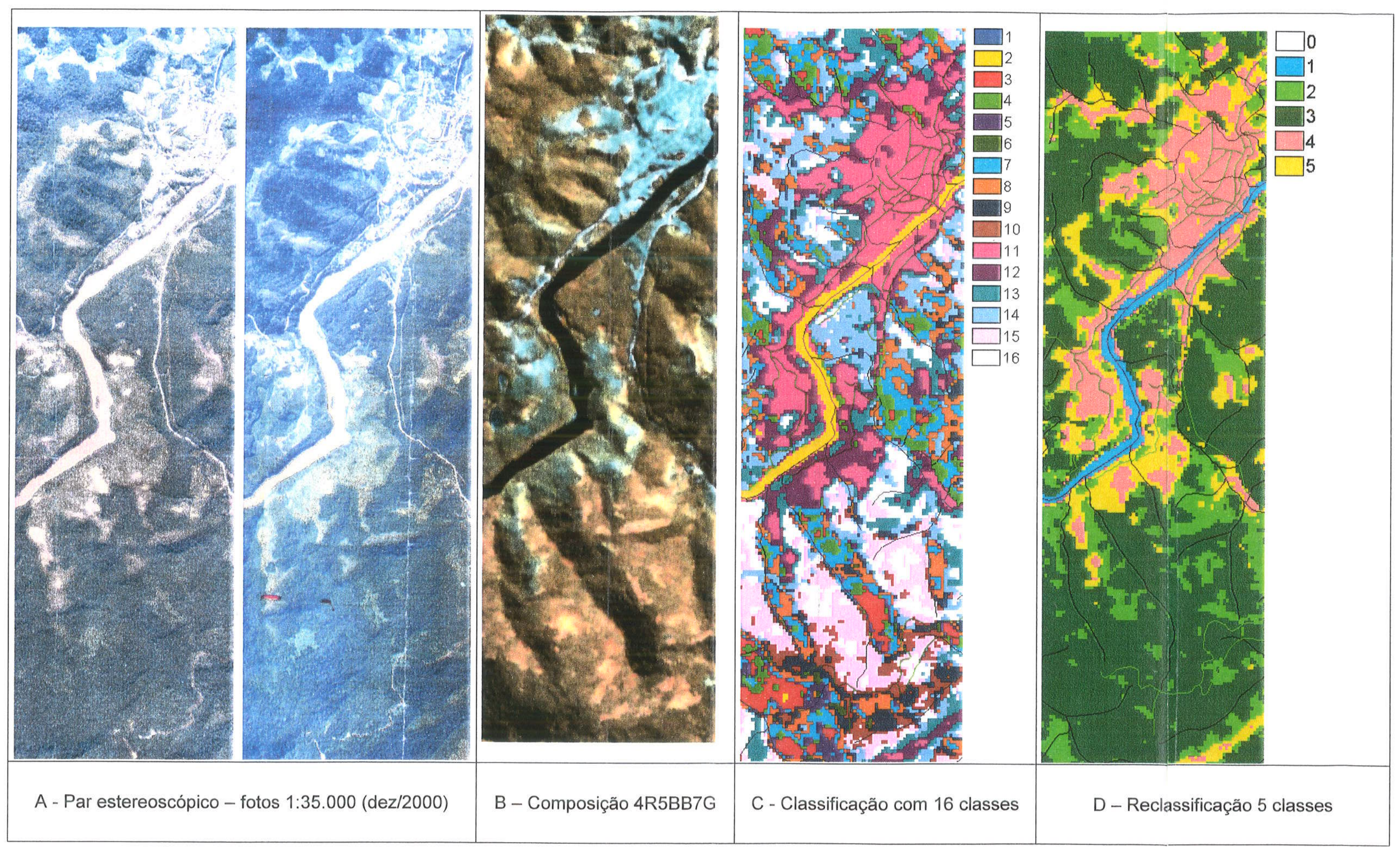

Figura 7.5 - Comparação entre as fotografias aéreas (1:35.000) (A), composição 4R5G7B (B), classificação inicial com 16 classes (C) e classificação final com 5 classes (D). 


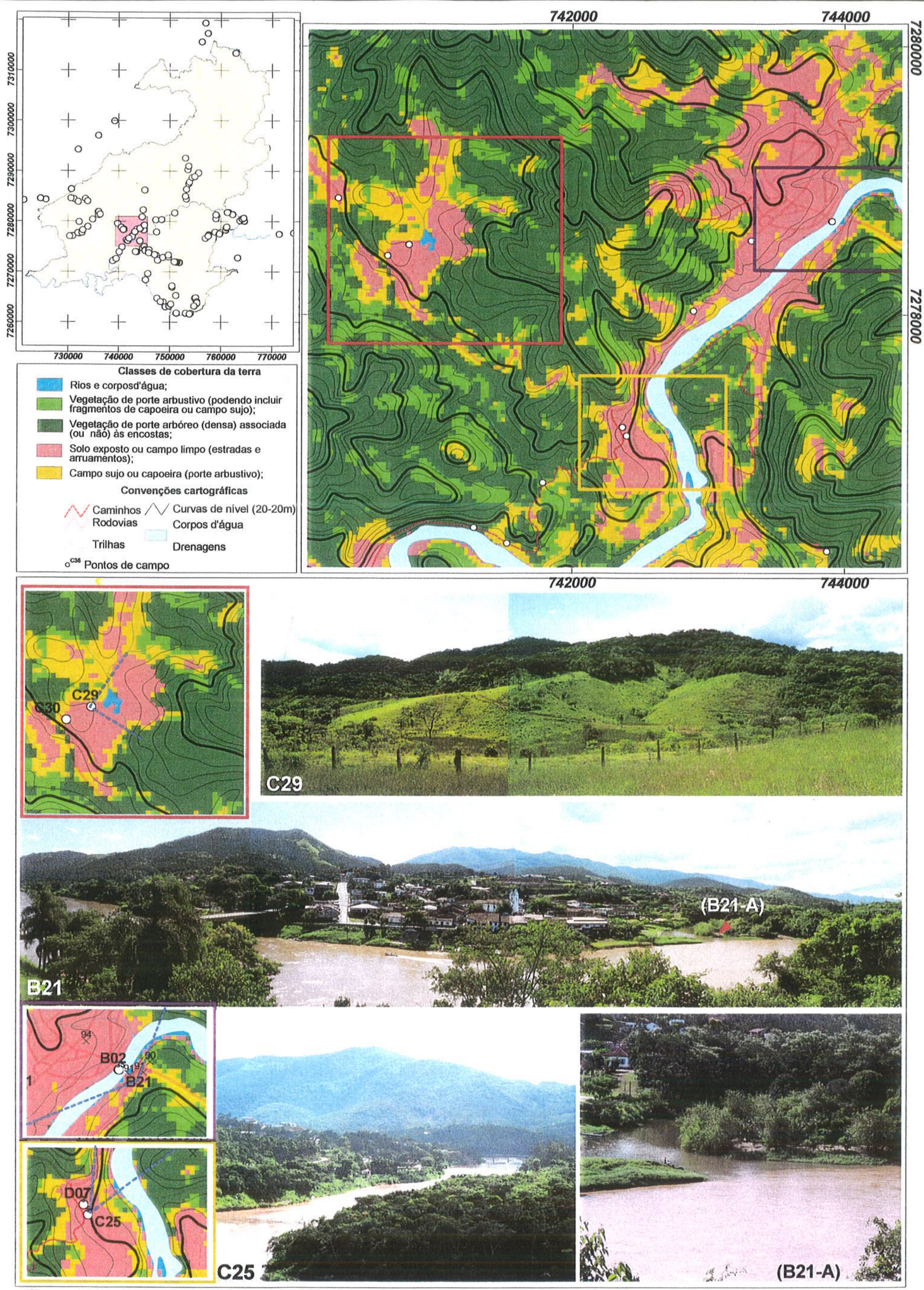

Figura 7.6 - Apresentação de alguns pontos de campo representativos dos tipos de coberturas, determinados na classsificacão. com fotoarafias panorâmicas. 


\subsubsection{Evolução da cobertura da terra (1990-2000)}

A evolução do uso do solo na área foi determinada a partir da tabulação cruzada entre a classificação gerada e o mapeamento do uso do solo e cobertura vegetal, efetuado pela Secretaria do Meio Ambiente (SMA, 1996) com dados de 1990. Este mapeamento constitui parte integrante do Macrozoneamento do Vale do Ribeira, as classes e unidades foram simplificadas para a análise de evolução da cobertura da terra, conforme apresentado na Tabela 7.7.

Tabela 7.7 - Categorias de vegetação do Mapa de Cobertura Vegetal e Uso do Solo da Secretaria do Meio Ambiente (1996) e equivalência com a legenda utilizada na classificação dos dados de sensoriamento remoto.

\begin{tabular}{|c|c|c|}
\hline $\begin{array}{l}\text { CATEGORIA } \\
\text { SMA (1996) }\end{array}$ & TIPOS, FORMAS E ELEMENTOS DE VEGETACÃO & $\begin{array}{l}\text { CATEGORIA } \\
\text { UTILIZADA }\end{array}$ \\
\hline $\begin{array}{l}\text { MATA } \\
\text { INTEGRA }\end{array}$ & $\begin{array}{c}\text { Mata Atlântica em fundos de vale, encostas e topos, de } \\
\text { origem primária ou secundária em bom estado de } \\
\text { conservação. }\end{array}$ & \multirow{3}{*}{$\begin{array}{l}\text { VEGETAÇÃO DE } \\
\text { PORTE ARBOREO } \\
\text { (DENSA) } \\
\text { ASSOCIADA (OU } \\
\text { NÃO) ȦS ENCOSTAS } \\
\text { (C3) }\end{array}$} \\
\hline $\begin{array}{c}\text { MATA } \\
\text { ALTERADA }\end{array}$ & $\begin{array}{l}\text { Mata Atlântica em fundos de vale, encostas e topos, } \\
\text { comumente de origem secundária, em bom estado de } \\
\text { conservação. }\end{array}$ & \\
\hline $\begin{array}{l}\text { MATA } \\
\text { DEGRADADA }\end{array}$ & $\begin{array}{l}\text { Mata Atlântica em fundos de vale, encostas e topos de } \\
\text { origem predominantemente secundária, com forte } \\
\text { rarefação do estrato superior original e indicando a } \\
\text { ocorrência de um processo de recolonização, } \\
\text { entremeados com remanescentes dos estratos mais altos. }\end{array}$ & \\
\hline $\begin{array}{l}\text { FASES } \\
\text { INTERMEDIARIA } \\
\text { SDE } \\
\text { SUCESSÄO } \\
\text { NATURAL }\end{array}$ & $\begin{array}{l}\text { Areas de recolonização, entre segunda e Quarta fase do } \\
\text { processo de sucessão natural. Inclui as "capoeiras ralas" e } \\
\text { "capoeira" propriamente dita. }\end{array}$ & $\begin{array}{l}\text { VEGETAÇÃO DE } \\
\text { PORTE ARBUSTIVO } \\
\text { (PODENDO INCLUIR } \\
\text { FRAGMENTOS DE } \\
\text { CAPOEIRA OU } \\
\text { CAMPO SUNO) (C2) } \\
\end{array}$ \\
\hline $\begin{array}{l}\text { CAMPOS } \\
\text { ANTROPICOS }\end{array}$ & $\begin{array}{l}\text { Processos pioneiros da ocupação do solo, entre primeira e } \\
\text { segunda fase de sucessão natural, resultantes do } \\
\text { abandono, mau uso por pastagens, da exaustão de } \\
\text { fertilidade e de terrenos roçados ou semeados. }\end{array}$ & $\begin{array}{l}\text { CAMPO SUJO OU } \\
\text { CAPOEIRA (C5) }\end{array}$ \\
\hline SOLO EXPOSTO & $\begin{array}{l}\text { Vegetação composta de espécies que se desenvolvem } \\
\text { sobre rochas expostas ou solos pedregosos. }\end{array}$ & $\begin{array}{l}\text { SOLO EXPOSTO OU } \\
\text { CAMPO LIMPO (C4) }\end{array}$ \\
\hline
\end{tabular}

Fonte: Simplificado de SMA (1996).

A Figura 7.7 apresenta uma sintese do quadro de evolução da cobertura da terra no município. A Tabela 7.8 indica as unidades que apresentaram uma evolução positiva, com recuperação ou recomposição parcial das áreas no período 1990-2000. 


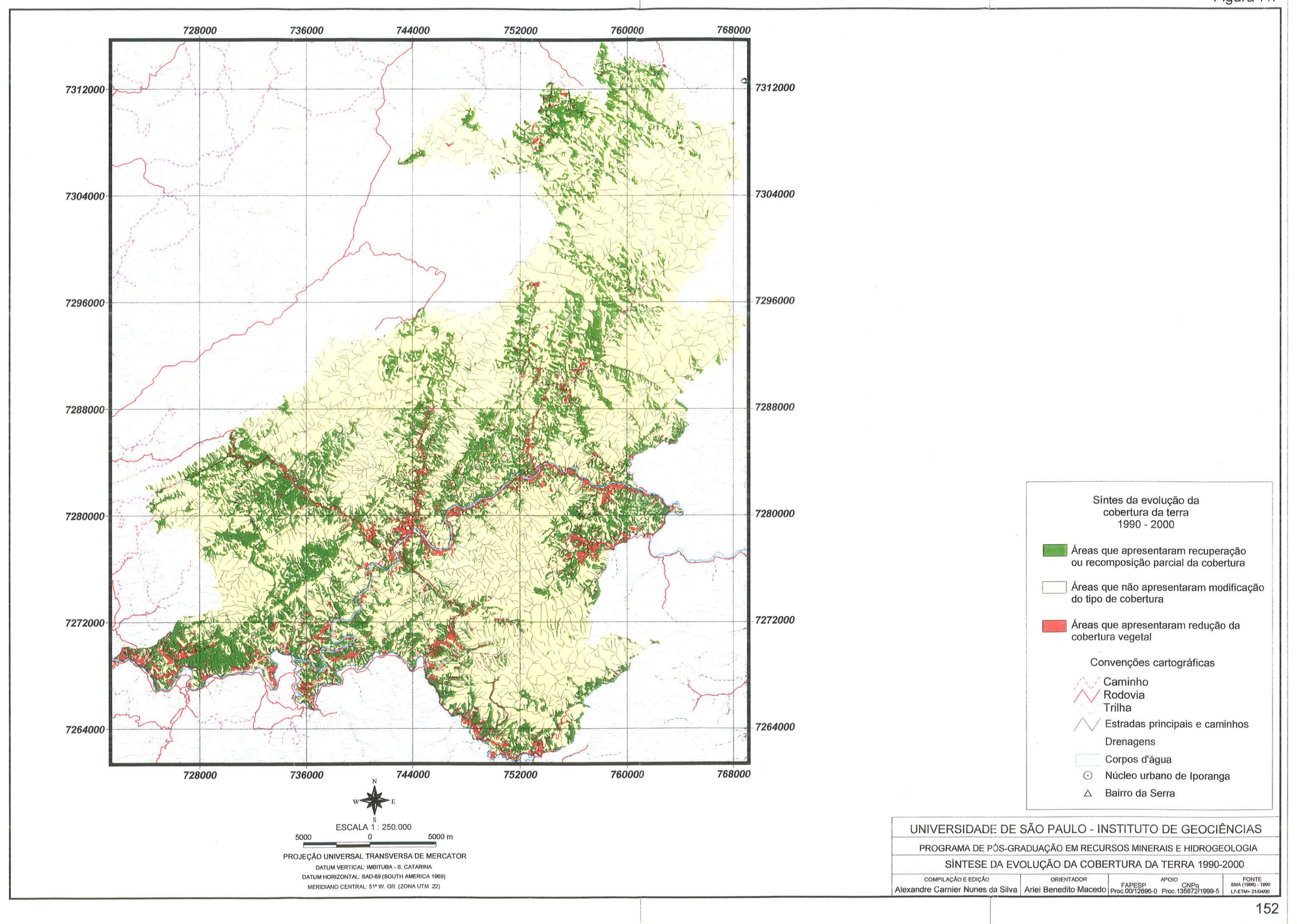


A Tabela 7.9 indica a relação das unidades que não apresentaram modificações no periodo. A evolução entre a vegetação de porte arbóreo para porte arbustivo foi considerada como uma manutenção das condições de cobertura, pois as áreas indicadas no mapa de cobertura da terra de 1990 (SMA, 1996), que apresentaram essa evolução, correspondem, na classificação de 2000, às áreas de porte arbustivo no interior das classes de vegetação de porte arbóreo.

A Tabela 7.10 indica as unidades que apresentaram uma redução na cobertura vegetal.

Tabela 7.8 - Evolução da cobertura da terra com recuperação, ou recomposição parcial, da cobertura vegetal.

\begin{tabular}{|c|c|c|}
\hline Área $\left(\mathrm{km}^{2}\right)$ & 1990 & 2000 \\
\hline 1,655 & Solo exposto (campo limpo) & Campo sujo (capoeira) \\
\hline 95,971 & Campo sujo (capoeira) & $\begin{array}{c}\text { Vegetaçao } \\
\text { porte arbóreo }\end{array}$ \\
\hline 5,210 & Solo exposto (campo limpo) & Vegetaçao \\
\hline 125,623 & Vegetaçáo porte arbustivo & porte arbustivo \\
\hline 1,651 & Solo exposto (campo limpo) & \\
\hline 46,475 & Campo sujo (capoeira) & \\
\hline Total & & \\
\hline
\end{tabular}

Tabela 7.9 - Evolução da cobertura da terra com manutenção do tipo de cobertura.

\begin{tabular}{|c|c|c|}
\hline Área $\left(\mathrm{km}^{2}\right)$ & $\mathbf{1 9 9 0}$ & $\mathbf{2 0 0 0}$ \\
\hline 25,677 & Campo sujo (capoeira) & Campo sujo (capoeira) \\
\hline 4,577 & Rios & Rios \\
\hline 1,013 & Solo exposto (campo limpo) & Solo exposto (campo limpo) \\
\hline 738,336 & Vegetaçao porte arbóreo & Vegetaçao porte arbóreo \\
\hline 94,338 & Vegetaçao porte arbóreo & Vegetação porte arbustivo \\
\hline 27,218 & Vegetação porte arbustivo & \\
\hline Total & & \\
\hline
\end{tabular}

Tabela 7.10 - Evolução da cobertura da terra com redução da cobertura vegetal.

\begin{tabular}{|c|c|c|}
\hline Área $\left(\mathbf{k m}^{2}\right)$ & 1990 & $\mathbf{2 0 0 0}$ \\
\hline 7,342 & Vegetaçao porte arbóreo & \multirow{2}{*}{ Campo sujo (capoeira) } \\
\hline 7,181 & Vegetação porte arbustivo & \\
\hline 20,154 & Campo sujo (capoeira) & \multirow{2}{*}{ Solo exposto (campo limpo) } \\
\hline 1,908 & Vegetaçao porte arbóreo & \\
\hline 2,681 & Vegetação porte arbustivo & \\
\hline Total & & \\
\hline
\end{tabular}


A análise das tabelas indica uma manutenção da cobertura da terra em $73 \%$ da área do municipio, recuperação da cobertura vegetal em $23 \%$ e degradação em $4 \%$ da área. A Figura 7.7 apresenta a distribuição espacial dessas áreas, que no caso da regeneração da cobertura vegetal, relaciona-se com áreas mais afastadas do centro urbano que foram abandonadas pelos moradores, enquanto as áreas de degradação estão relacionadas ao crescimento do entorno da área urbana, e pequenos núcleos populacionais como o Bairro da Serra.

\subsubsection{Análise da cobertura da terra nas unidades de conservação}

A cobertura da terra relativa às unidades de conservação foi determinada com a tabulação cruzada entre a classificação gerada, com os dados de sensoriamento remoto e os limites dessas unidades. Foram determinados os tipos de cobertura predominantes em cada unidade e a distribuição geral de cada categoria de cobertura da terra em relação às classes do mapa de unidades de conservação (Tabelas $7.11 \mathrm{e}$ 7.12 , respectivamente).

Tabela 7.11 - Distribuição porcentual das classes de cobertura da terra em cada uma das classes de unidades de conservação.

\begin{tabular}{|c|c|c|c|c|c|c|c|c|c|}
\hline UCs & Fora & $\begin{array}{c}\text { Remanes- } \\
\text { centes de } \\
\text { UCullombo }\end{array}$ & $\begin{array}{c}\text { Área de } \\
\text { Tomba- } \\
\text { mento }\end{array}$ & $\begin{array}{c}\text { APA } \\
\text { Serra do } \\
\text { Mar }\end{array}$ & $\begin{array}{c}\text { Parque } \\
\text { Intervales e } \\
\text { APA Serra } \\
\text { do Mar }\end{array}$ & $\begin{array}{c}\text { Parque } \\
\text { Intervales }\end{array}$ & $\begin{array}{c}\text { Parque } \\
\text { PETAR }\end{array}$ & $\begin{array}{c}\text { Parque } \\
\text { Estadual } \\
\text { Jacupiranga }\end{array}$ & $\begin{array}{c}\text { APA } \\
\text { Serra } \\
\text { do Mar } \\
\text { (ZVS) }\end{array}$ \\
\hline $\begin{array}{c}\text { Rios e corpos } \\
\text { d'água }\end{array}$ & 1,4 & 0,0 & 0,8 & 1,2 & 0,0 & 0,0 & 0,0 & 0,0 & 2,0 \\
\hline $\begin{array}{c}\text { Vegetação de } \\
\text { porte arbustivo }\end{array}$ & 17,3 & 9,6 & 12,5 & 13,4 & 23,6 & 19,7 & 11,5 & 11,3 & 22,6 \\
\hline $\begin{array}{c}\text { Vegetaçăo de } \\
\text { porte arbóreo }\end{array}$ & 66,0 & 88,1 & 78,2 & 74,6 & 76,4 & 80,2 & 86,3 & 84,7 & 59,0 \\
\hline $\begin{array}{c}\text { Solo exposto ou } \\
\text { campo limpo }\end{array}$ & 5,8 & 0,4 & 3,6 & 4,3 & 0,0 & 0,0 & 0,6 & 1,6 & 7,3 \\
\hline Campo sujo & 9,5 & 1,9 & 4,9 & 6,5 & 0,0 & 0,1 & 1,6 & 2,4 & 9,1 \\
\hline Totais (\%) & 100 & 100 & 100 & 100 & 100 & 100 & 100 & 100 & 100 \\
\hline $\begin{array}{c}\text { Area totall } \\
\text { hectares) }\end{array}$ & 6021,8 & 10618,5 & 17947,1 & 26424,7 & 4607,6 & 17718,7 & 25266,5 & 10285,1 & 2342,2 \\
\hline
\end{tabular}

Tabela 7.12 - Distribuição porcentual das classes de cobertura da terra para todas as classes de unidades de conservação.

\begin{tabular}{|l|c|c|c|c|c|c|c|c|c|c|c|}
\hline Cobertura & Fora & $\begin{array}{c}\text { Remanes- } \\
\text { UCs }\end{array}$ & $\begin{array}{c}\text { Area de } \\
\text { Quilos de }\end{array}$ & $\begin{array}{c}\text { APA } \\
\text { Tombaa } \\
\text { Serra } \\
\text { do } \\
\text { Mar }\end{array}$ & $\begin{array}{c}\text { Parque } \\
\text { Intervales } \\
\text { e APA } \\
\text { Serra do } \\
\text { Mar }\end{array}$ & $\begin{array}{c}\text { Parque } \\
\text { Intervales }\end{array}$ & $\begin{array}{c}\text { Parque } \\
\text { PETAR }\end{array}$ & $\begin{array}{c}\text { Parque } \\
\text { Estadual } \\
\text { Jacupiranga }\end{array}$ & $\begin{array}{c}\text { APA } \\
\text { Serra do } \\
\text { Mar (ZVS) }\end{array}$ & $\begin{array}{c}\text { Totais } \\
\text { (\%) }\end{array}$ & $\begin{array}{c}\text { Área } \\
\text { total } \\
\text { (hectares) }\end{array}$ \\
\hline $\begin{array}{c}\text { Rios e corpos } \\
\text { d'água }\end{array}$ & 14,0 & 0,0 & 23,8 & 54,1 & 0,0 & 0,0 & 0,0 & 0,0 & 8,1 & 100 & 589,8 \\
\hline $\begin{array}{c}\text { Vegetaçāo de } \\
\text { porte } \\
\text { arbustivo }\end{array}$ & 6,1 & 6,0 & 13,2 & 20,8 & 6,4 & 20,5 & 17,1 & 6,8 & 3,1 & 100 & 16986,1 \\
\hline $\begin{array}{c}\text { Vegetaçăo de } \\
\text { porte arbóreo }\end{array}$ & 4,1 & 9,7 & 14,5 & 20,4 & 3,6 & 14,7 & 22,6 & 9,0 & 1,4 & 100 & 96733,3 \\
\hline $\begin{array}{c}\text { Solo exposto } \\
\text { ou campo } \\
\text { limpo }\end{array}$ & 13,1 & 1,5 & 24,0 & 42,7 & 0,0 & 0,2 & 5,7 & 6,3 & 6,4 & 100 & 2683,5 \\
\hline Campo sujo & 13,4 & 4,8 & 20,8 & 40,4 & 0,0 & 0,3 & 9,5 & 5,8 & 5,0 & 100 & 4239,7 \\
\hline
\end{tabular}




\subsubsection{Evolução da cobertura da terra nas unidades de conservação}

A evolução da cobertura da terra nas áreas relativas às unidades de conservação foi determinada com a tabulação cruzada entre a classificação síntese dessa evolução, em três classes, conforme apresentado no item 7.1.4. e as classes do mapa de unidades de conservação, caracterizando o tipo de evolução predominante em cada unidade de conservação e a distribuição geral de cada categoria de evolução da terra (Tabelas 7.13 e 7.14 , respectivamente).

Tabela 7.13 - Distribuição porcentual das classes de evolução da cobertura em cada classe de unidades de conservação.

\begin{tabular}{|c|c|c|c|c|c|c|c|c|c|}
\hline $\begin{array}{c}\text { Evoluçăo } \\
\text { Cobertura }\end{array}$ & Fora Ucs & $\begin{array}{c}\text { Remanes- } \\
\text { centes de } \\
\text { quilombo }\end{array}$ & $\begin{array}{c}\text { Área de } \\
\text { Tomba- } \\
\text { mento }\end{array}$ & $\begin{array}{c}\text { APA } \\
\text { Serra do } \\
\text { Mar }\end{array}$ & $\begin{array}{c}\text { Parque } \\
\text { Intervales e } \\
\text { APA Serra } \\
\text { do Mar }\end{array}$ & $\begin{array}{c}\text { Parque } \\
\text { Intervales }\end{array}$ & $\begin{array}{c}\text { Parque } \\
\text { PETAR }\end{array}$ & $\begin{array}{c}\text { Parque } \\
\text { Estadual } \\
\text { Jacupiranga }\end{array}$ & $\begin{array}{c}\text { APA } \\
\text { Serra } \\
\text { do Mar } \\
\text { (ZVS) }\end{array}$ \\
\hline $\begin{array}{c}\text { Em } \\
\text { recuperação }\end{array}$ & 40,5 & 29,7 & 24,6 & 28,4 & 13,1 & 11,5 & 21,7 & 11,3 & 36,2 \\
\hline $\begin{array}{c}\text { Sem } \\
\text { modificação }\end{array}$ & 49,9 & 68,4 & 70,8 & 65,8 & 86,8 & 88,4 & 77,4 & 86,0 & 53,5 \\
\hline Degradação & 9,6 & 1,9 & 4,7 & 5,8 & 0,0 & 0,1 & 0,9 & 2,7 & 10,3 \\
\hline Totais (\%) & 100 & 100 & 100 & 100 & 100 & 100 & 100 & 100 & 100 \\
\hline $\begin{array}{c}\text { Area total } \\
\text { (hectares) }\end{array}$ & 6032,8 & 10622,0 & 17951,8 & 26443,2 & 4611,4 & 17732,9 & 25289,1 & 10294,7 & 2350,4 \\
\hline
\end{tabular}

Tabela 7.14 - Distribuição porcentual das classes de evolução da cobertura para todas as unidades de conservação.

\begin{tabular}{|c|c|c|c|c|c|c|c|c|c|c|c|}
\hline $\begin{array}{l}\text { Evolução } \\
\text { Cobertura }\end{array}$ & $\begin{array}{c}\text { Fora } \\
\text { UCs }\end{array}$ & $\begin{array}{c}\text { Remanes- } \\
\text { centes de } \\
\text { quilombo }\end{array}$ & $\begin{array}{c}\text { Area de } \\
\text { Tomba- } \\
\text { mento }\end{array}$ & $\begin{array}{c}\text { APA } \\
\text { Serra } \\
\text { do } \\
\text { Mar }\end{array}$ & $\begin{array}{c}\text { Parque } \\
\text { Intervales } \\
\text { e APA } \\
\text { Serra do } \\
\text { Mar }\end{array}$ & $\begin{array}{c}\text { Parque } \\
\text { Intervales }\end{array}$ & $\begin{array}{c}\text { Parque } \\
\text { PETAR }\end{array}$ & $\begin{array}{c}\text { Parque } \\
\text { Estadual } \\
\text { Jacupiranga }\end{array}$ & $\begin{array}{c}\text { APA } \\
\text { Serra do } \\
\text { Mar (ZVS) }\end{array}$ & $\begin{array}{c}\text { Totais } \\
\text { (\%) }\end{array}$ & $\begin{array}{c}\text { Area } \\
\text { total } \\
\text { (hectares) }\end{array}$ \\
\hline $\begin{array}{c}\text { Eecuperaçăo } \\
\text { modificação }\end{array}$ & 8,8 & 11,4 & 15,9 & 27,2 & 2,2 & 7,4 & 19,8 & 4,2 & 3,1 & 100 & 27658,5 \\
\hline Degradação & 14,7 & 5,1 & 21,4 & 39,3 & 0,0 & 0,3 & 6,1 & 7,0 & 6,2 & 100 & 3926,7 \\
\hline
\end{tabular}




\subsection{Geoprocessamento}

A definição dos parâmetros da análise por geoprocessamento seguiu a rotina necessária para utilização do módulo MCE (Multi Criteria Evaluation) do programa Idrisi32, baseado na Combinação Linear Ponderada (WLC - Weighted Linear Combination) que exige a definição de fatores e pesos de importância para cada fator. Os fatores e pesos foram definidos por meio da análise pareada, empregando o processo analitico hierárquico (AHP).

A técnica AHP exige um entendimento do relacionamento existente entre os fatores condicionantes dos processos que estão sendo analisados e o grau de compensação entre cada fator. A variação dos intervalos críticos definidos para cada um dos fatores utilizados, e a interpretação do produto final integrado, refletirá um maior ou menor risco assumido em relação a definição de áreas com alta suscetibilidade ou baixa suscetibilidade ao processo em questão.

A produção das cartas de suscetibilidade aos processos analisados empregou fatores apresentados na Tabela 7.15, com diferenças relativas às pontuações, em uma escala de 0 a 5 , indicando a maior suscetibilidade associada a cada classe dos mapas temáticos.

Tabela 7.15 - Fatores utilizados nas análises e critérios utilizados na etapa de parametrização.

\begin{tabular}{|c|c|c|c|c|}
\hline $\begin{array}{l}\text { Fatores } \\
\text { utilizados }\end{array}$ & $\begin{array}{l}\text { Número } \\
\text { De } \\
\text { Classes }\end{array}$ & \multicolumn{2}{|c|}{$\begin{array}{l}\text { Critério de pontuação } \\
\text { (Escala: } 0 \text { } 5 \text { ) } \\
\text { Suscetibilidade cresce em função da: }\end{array}$} & $\begin{array}{l}\text { Parametrizaçāo } \\
(0-255)\end{array}$ \\
\hline Geologia & 46 & \multicolumn{2}{|c|}{$\begin{array}{l}\text { Baixa coesão/resistência do material } \\
\qquad(a=0 ; b, c, d=5)\end{array}$} & \multirow[t]{2}{*}{ Fuzzy linear } \\
\hline Geomorfologia & 25 & \multicolumn{2}{|c|}{$\begin{array}{l}\text { Alta amplitude/dissecação do relevo } \\
\qquad(a=0 ; b, c, d=5)\end{array}$} & \\
\hline Pedologia & 13 & \multicolumn{2}{|c|}{$\begin{array}{l}\text { Maior fragilidade do perfil do solo } \\
\qquad(a=0 ; b, c, d=5)\end{array}$} & \\
\hline Uso e ocupação & 5 & \multicolumn{2}{|c|}{$\begin{array}{l}\text { Menor proteção do solo (cobertura vegetal) } \\
\qquad(a=0 ; b, \mathbf{c}, \mathbf{d}=5)\end{array}$} & \\
\hline \multirow[b]{2}{*}{ Declividade } & & $\begin{array}{l}\text { Processos de } \\
\text { movimento de massa }\end{array}$ & $\begin{array}{l}\text { Processos } \\
\text { erosivos }\end{array}$ & \multirow[t]{2}{*}{ Fuzzy sigmoidal } \\
\hline & $\begin{array}{c}0-65^{\circ} \\
(0-216 \%)\end{array}$ & $\begin{array}{c}\quad 0-30^{\circ} \\
\text { Ângulo de vertente a partir do } \\
\text { qual a incidência de } \\
\text { movimentos de massa } \\
\text { aumentam significativamente } \\
a=0 \\
b, c, d=30\end{array}$ & $\begin{array}{c}0-20 \% \\
\text { Angulo da rampa } \\
\text { limite que } \\
\text { favorece a } \\
\text { desagregação e } \\
\text { transporte de } \\
\text { sedimentos } \\
\text { a=0 } \\
\text { b,c,d=20 }\end{array}$ & \\
\hline
\end{tabular}




\subsubsection{Carta de suscetibilidade aos movimentos de massa}

A etapa de pontuação dos mapas temáticos obedeceu ao principio geral da hierarquização, baseada na identificação inicial das condições mais e menos favoráveis para cada fator analisado, seguida da classificação dos niveis intermediários, por comparação com essas condições limite.

Nos itens a seguir são discutidos cada um dos fatores considerados na elaboração da carta de suscetibilidade aos movimentos de massa.

\subsubsection{Fator geologia}

As unidades consideradas mais críticas em relação aos processos de movimento de massa receberam a pontuação 5 (suscetibilidade muito alta), indicando que apresentam menor resistência (ângulo de atrito e coesão). As unidades que representam os sedimentos inconsolidados do Quaternário e Terciário, com baixa resistência, receberam a pontuação 5 , apesar de apresentarem uma distribuição restrita e pouco associada aos setores de vertente mais ingremes e favoráveis à deflagração de movimentos de massa.

As demais unidades, com predominância de filitos e metassiltitos, que de maneira geral apresentam estruturas desfavoráveis, foram pontuadas com o valor 4 , indicando uma alta suscetibilidade. Os metarenitos, metaconglomerados e metargilitos receberam pontuação 3.5 , o que indica uma situação intermediária entre a média e alta suscetibilidade. As unidades carbonáticas e básicas (metabasitos e diques) receberam as pontuações 2 e 1 , respectivamente, baixa e muito baixa suscetibilidade.

A Tabela 7.16 apresenta as unidades geológicas consideradas na análise e a pontuação utilizada.

Tabela 7.16 - Descrição das unidades geológicas e pontuações utilizadas na análise de suscetibilidade.

\begin{tabular}{|c|c|c|c|}
\hline $\begin{array}{c}\text { Unidade } \\
\text { (ID) }\end{array}$ & $\begin{array}{l}\text { Sigla da } \\
\text { Unidade }\end{array}$ & Descrição da unidade geológica & Pontuação utilizada \\
\hline 1 & Qa & Aluvioes em geral e sedimentos coluviais & 5 \\
\hline 2 & TQC & Conglomerados semi-consolidados, Areias e Argilas & 5 \\
\hline 3 & $\mathrm{JKb}$ & Diques e sills de rochas básicas & 1 \\
\hline 4 & $\mathrm{CNeG}$ & Corpos Granitóldes: Álcali-sienito pórfiro, Bombas, Tonalitos e Microgranitos & 2 \\
\hline 8 & NMvpM & Mármores, em geral bandados, calcíticos e dolomíticos & 2 \\
\hline 9 & NMvsA & Metarenitos, localmente conglomeráticos com intercalaçoes de Metassitutitos & 3.5 \\
\hline 10 & NMvmM & $\begin{array}{c}\text { Mármores impuros, margosos, predominantemente calcíticos, cinza escuros, } \\
\text { sulfetados, com intercalaçōes de Filitos carbonáticos, Metassiltitos e } \\
\text { Metarenitos }\end{array}$ & 2 \\
\hline 11 & NMvmF & Filitos & 4 \\
\hline 12 & NMvaF & Filitos, Metassiltitos e Metarenitos finos & 4 \\
\hline 13 & NMvbM & $\begin{array}{c}\text { Mámores impuros, margosos, predominantemente calcíticos, cinza escuros, } \\
\text { sulfetados, com intercalações de Filitos carbonáticos, Metassilkitos e } \\
\text { Metarenitos }\end{array}$ & 2 \\
\hline
\end{tabular}




\begin{tabular}{|c|c|c|c|}
\hline 14 & NMvbS & Metassiltitos e filitos com intercalaçð̋es de metarenitos finos & 3.5 \\
\hline 15 & NMvbA & $\begin{array}{c}\text { Metarenitos com niveis e lentes de Metaconglomerados oligomíticos, } \\
\text { Metarenitos arcoseanos, Metarenitos com granulos e Metassiltitos e filitos } \\
\text { subordinados }\end{array}$ & 3.5 \\
\hline 16 & NMiA & Metarenitos e Metaconglomerados polimíticos com matriz arcoseana & 3.5 \\
\hline 17 & NMF & $\begin{array}{l}\text { Metarritimitos finos, predominando Metassiltitos com intercalaçoes de } \\
\text { Metargilitos, Metarenitos metarcóseos e Filitos carbonáticos }\end{array}$ & 3.5 \\
\hline 18 & NMiQ & Quartzitos (Metarenitos) com intercalações de Metassiltitos & 1 \\
\hline 19 & NMiC & Metaconglomerados e Metabrechas polimiticas com matriz filitica & 3.5 \\
\hline 20 & NMvrF & $\begin{array}{c}\text { Metarritimitos finos, predominantemente Metassillitos finos, com intercalaçoes } \\
\text { de Metargilitos, Metarenitos, Carbonato filitos, Clorita filitos, Filitos grafitosos, } \\
\text { Mármores, Metacherts, Metatufos e Xistos verdes }\end{array}$ & 3.5 \\
\hline 22 & NMvrFM & Carbonato filitos com bandas de Mármores & 3.5 \\
\hline 23 & NMvrQ & Quartzitos (Metarenitos e Metassiltitos) & 1 \\
\hline 24 & NMvrAC & Metaconglomerados oligomíticos & 3.5 \\
\hline 25 & NMvrFF & Formaçőes ferriferas & 2 \\
\hline 26 & MNvrR & Metargilitos e Metassiltitos finos com estrutura maciça predominante & 3.5 \\
\hline 27 & NMvrC & Metabasitos (Carbonato fels, Clorita mitonitos) & 1 \\
\hline 28 & NMvrB & Metabasitos (Actinolita anfibolitos, Piroxênio anfibolitos, Clorita milonitos) & 1 \\
\hline 29 & NMvrFX & $\begin{array}{l}\text { Filitos e Xistos finos, por vezes com intercalaçöes centim,tricas a decim,tricas } \\
\text { de Quartzo xistos e Quartzitos }\end{array}$ & 4 \\
\hline 30 & NMvrM & Mármores & 1 \\
\hline 31 & NMvrD & Metabasitos (Hornblenda anfibolitos) & 1 \\
\hline 32 & NMvMT & $\begin{array}{c}\text { Mármores em geral dolomiticos, finos, maciços, brancos, passando localmente } \\
\text { a quartzitos e mármores cinzentos }\end{array}$ & 1 \\
\hline 33 & MNscF & Filitos cinzentos & 4 \\
\hline 34 & NMscM & $\begin{array}{c}\text { Mármores calciticos e dolomiticos, associados por vezes a brechas } \\
\text { quartzosas finas }\end{array}$ & 1 \\
\hline 35 & $\mathrm{NMScQ}$ & Quartzitos & 1 \\
\hline 36 & MNsFX & $\begin{array}{l}\text { Filitos e Xistos finos, subordinadamente Quartzo-biotita-muscovita xistos, } \\
\text { Clorita xistos, Mica-quartzo xistos e Xistos grafitosos }\end{array}$ & 4 \\
\hline 37 & MNsQ & Quartzitos & 1 \\
\hline 38 & MNsMa & \begin{tabular}{|c} 
Mármores \\
\end{tabular} & 1 \\
\hline 39 & NMSAX & $\begin{array}{c}\text { (Granada)-quartzo-biotita-muscovita xistos, por vezes com estaurolita, } \\
\text { cordierita, sillimanita e plagioclásio, passando localmente a xistos feldspáticos } \\
\text { e paragnaisses }\end{array}$ & 4 \\
\hline 40 & NMsM & Mármores, em geral dolomíticos, finos, maciços e silicosos & 1 \\
\hline 41 & PgmME & $\begin{array}{l}\text { Migmatitos, predominantemente bandados, com paleossoma de biotita elou } \\
\text { hornblenda gnaisses, por vezes fortemente milonitizados }\end{array}$ & 3 \\
\hline 42 & NMacX & MicanXistos & 4 \\
\hline 43 & NmacCS & $\begin{array}{l}\text { Rochas silicáticas, cálcio xistos, mármores e intercalaçōes subordinadas de } \\
\text { quartzos xistos }\end{array}$ & 2.5 \\
\hline 44 & NagG & Complexo Granitóide Indiferenciado & 2 \\
\hline 45 & $\mathrm{NmiQ}$ & Quartzitos (Metarenitos) com intercalações de Metassiltitos & 1 \\
\hline 46 & NMSFX & $\begin{array}{c}\text { Filitos e xistos finos, subordinadamente quartzo-biotita-muscovita xistos, clorita } \\
\text { xistos, mica quartzo xistos e xistos grafitosos }\end{array}$ & 4 \\
\hline
\end{tabular}

\subsubsection{Fator geomorfologia}

As unidades consideradas mais críticas em relação aos processos de movimento de massa foram aquelas que apresentam a associação de maiores amplitudes de relevo e declividade, e geralmente relacionam-se aos sistemas de relevo do tipo escarpa e montanhas. As demais unidades, que representam associações de morros e morrotes, foram consideradas como de média suscetibilidade; $e$ as unidades planície fluvial e terraços foram consideradas como de baixa suscetibilidade para 
processos de movimento de massa e alta suscetibilidade para processos erosivos, conforme apresentado na Tabela 7.17.

Tabela 7.17 - Descrição das unidades geomorfológicas e pontuações utilizadas na análise de suscetibilidade.

\begin{tabular}{|c|c|c|c|c|}
\hline $\begin{array}{l}\text { Unidade } \\
\text { (ID) }\end{array}$ & Sigla da unidade & Descrição da unidade & $\begin{array}{c}\text { Pontuação utilizada } \\
\text { Processos de } \\
\text { Movimento de Massa } \\
(0-5) \\
\end{array}$ & $\begin{array}{c}\text { Pontuação utilizada } \\
\text { Processos } \\
\text { Erosivos } \\
(0-5)\end{array}$ \\
\hline 1 & MTpq1 & Morrotes pequenos & 2 & 2 \\
\hline 2 & MT1 & Morrotes & 2 & 2 \\
\hline 3 & MTm1 & Morrotes e morros & 2 & 2 \\
\hline 4 & CRmtp & Cristas e morros paralelos & 2.5 & 2.5 \\
\hline 5 & MTmc1 & Morrotes e morros cársticos & 3.5 & 3.5 \\
\hline 6 & $\mathrm{Mm} 1$ & Morros maciços & 4 & 4 \\
\hline 7 & CR1 & Cristas & 4 & 4 \\
\hline 8 & E2 & Escarpas & 5 & 5 \\
\hline 9 & Ev2 & Escarpas degradadas por vales paralelos & 5 & 5 \\
\hline 10 & Ea2 & Escarpas degradadas por anfiteatros & 5 & 5 \\
\hline 11 & Ec2 & Escarpas com degradaçäo complexa & 5 & 5 \\
\hline 12 & MH2 & Montanhas & 4.5 & 4.5 \\
\hline 13 & $\mathrm{MHm} 2$ & Montanhas e morros & 4.5 & 4.5 \\
\hline 14 & $\mathrm{Mg} 2$ & Morros graníticos & 4 & 4 \\
\hline 15 & $\mathrm{CR} 2$ & Cristas & 4 & 4 \\
\hline 16 & CRmp2 & Cristas e morros paralelos & 4 & 4 \\
\hline 17 & MTpd3 & Morrotes pedimentares & 3 & 3 \\
\hline 18 & $\mathrm{PF}$ & Planicie fluvial & 1 & 4 \\
\hline 19 & $\mathrm{~T} 2$ & Terraços intermediários & 1 & 4 \\
\hline 20 & T3 & Terraços antigos & 1 & 4 \\
\hline 21 & Dol & Dolinas & 1.5 & 1.5 \\
\hline 22 & Cdej & Cones de dejeção e corpos de tálus & 3 & 3 \\
\hline 23 & MTmct & Morrotes e morros cársticos & 3.5 & 3.5 \\
\hline 24 & RPTP & Rampas & 2 & 2 \\
\hline 25 & Mo1 & Morros & 3.5 & 3.5 \\
\hline
\end{tabular}

\subsubsection{Fator pedologia}

As unidades consideradas mais críticas, em relação aos processos de movimento de massa, são aquelas que apresentam menor resistência aos processos de instabilização.

Considerando-se a evolução dos processos de alteração química e física na formação dos solos, aqueles de origem residual e mais evoluídos pedologicamente, em conjunto com os de origem não residual (materiais transportados, depósitos), apresentam menor resistência média, e portanto, maior suscetibilidade aos movimentos de massa. A presença de estruturas pedológicas especificas, como horizontes menos permeáveis (mais argilosos), também pode favorecer a deflagração de processos de instabilização. 
As unidades consideradas como de menor resistência foram os solos aluviais distróficos, seguidos pelos solos podzólicos, com muito alta e alta suscetibilidade, respectivamente. Os latossolos, brunizém e cambissolos (associados com litossolos) foram considerados, respectivamente, como de média, baixa e muito baixa suscetibilidade aos processos de movimento de massa. Os solos gleizados distróficos foram considerados como de alta suscetibilidade aos processos de movimento de massa e muito baixa suscetibilidade aos processo erosivos, pois apresentam-se saturados favorecendo a instabilização da vertente, mas não apresenta situação favorável à desagregação de partículas e transporte de sedimentos. A Tabela 7.18 apresenta a pontuação atribuida para cada unidade na análise para os processos de movimento de massa e erosão.

Tabela 7.18 - Descrição das unidades pedológicas e pontuações utilizadas na análise de suscetibilidade aos movimentos de massa e processos erosivos.

\begin{tabular}{|c|c|c|c|c|}
\hline $\begin{array}{l}\text { Unidade } \\
\text { (ID) }\end{array}$ & $\begin{array}{l}\text { Sigla da } \\
\text { Unidade }\end{array}$ & Descrição da unidade & $\begin{array}{c}\text { Pontuaçäo utilizada } \\
\text { Processos de } \\
\text { Movimento de Massa } \\
(0-5)\end{array}$ & $\begin{array}{c}\text { Pontuação utilizada } \\
\text { Processos } \\
\text { Erosivos } \\
(0-5)\end{array}$ \\
\hline 1 & LVa3 & $\begin{array}{l}\text { Latossolo vermelho-amarelo } \\
\text { álico }\end{array}$ & 3 & 3 \\
\hline 2 & PVd2 & $\begin{array}{c}\text { Podzólico vermelho amarelo } \\
\text { distrófico }\end{array}$ & 4 & 4 \\
\hline 3 & PVa6 & $\begin{array}{c}\text { /podzólico vermelho amarelo } \\
\text { álico }\end{array}$ & 4 & 4 \\
\hline 4 & BV2 & Brunizém avermelhado & 3 & 3 \\
\hline 5 & $\mathrm{Ce} 2$ & Cambissolo eutrófico & 2 & 2 \\
\hline 6 & $\mathrm{Cd} 2$ & Cambissolo distrófico & 2 & 2 \\
\hline 7 & $\mathrm{Ca} 2$ & \multirow{3}{*}{ Cambissolos álicos } & 2 & 2 \\
\hline 8 & $\mathrm{Ca3}$ & & 2 & 2 \\
\hline 9 & $\mathrm{Ca} 4$ & & 2 & 2 \\
\hline 10 & $G d$ & Gleizados distróficos & 5 & 1 \\
\hline 11 & A & Aluviais distróficos & 5 & 5 \\
\hline 12 & Ra1 & \multirow{2}{*}{ Litólicos álicos } & 2 & 2 \\
\hline 13 & Ra3 & & 1 & 1 \\
\hline
\end{tabular}

\subsubsection{Fator cobertura da terra}

As unidades que proporcionam menor proteção da superfície foram consideradas as mais críticas em relação aos processos de movimentos de massa e erosão.

As unidades que apresentam interferência antrópica foram consideradas como aquelas que proporcionam menor proteção e permitem, de maneira geral, um escoamento superficial mais rápido, e que conforme a duração e intensidade do evento chuvoso pode favorecer ainda mais a saturação da camada superficial, ou devido a constituição, favorecer a desagregação e transporte de sedimentos. 
A Tabela 7.19 apresenta a pontuação atribuida para cada unidade na análise para os processos de movimento de massa e erosão.

Tabela 7.19 - Descrição das unidades de cobertura da terra e pontuações utilizadas na análise de suscetibilidade aos movimentos de massa e processos erosivos.

\begin{tabular}{|c|c|c|}
\hline $\begin{array}{c}\text { Unidade } \\
\text { (ID) }\end{array}$ & Sigla / Descriçäo da unidade & $\begin{array}{c}\text { Pontuação utilizada processos de: } \\
\text { Movimento de Massa e } \\
\text { Erosivos (0-5) }\end{array}$ \\
\hline 1 & C1 - Rios e corposd'água; & 0 \\
\hline 2 & C2 - Vegetação de porte arbustivo (podendo incluir fragmentos de capoeira ou & 2 \\
\hline 3 & campo sujo); & 1 \\
\hline 4 & C4 - Vegetação de porte arbóreo (densa) associada (ou não) às encostas; & 5 \\
\hline 5 & C5 - Colo exposto ou campo limpo (estradas e arruamentos); & 4 \\
\hline
\end{tabular}

\subsubsection{Fator declividade}

O tratamento dos dados de declividade utilizou a conversão direta para o limite 0 -255, utilizando a padronização fuzzy com função sigmoidal crescente com os seguintes pontos de controle da curva: $a=0^{\circ}$ e $b, c, d=30^{\circ}$. Esses valores representam dois conjuntos hipotéticos: o conjunto das declividades que não apresentam nenhuma suscetibilidade aos processos de movimento de massa e o limite médio de declividade, a partir do qual a suscetibilidade aos processos é elevada.

A utilização desse tipo de curva permite definir, de forma mais realista, a gradação entre os dois conjuntos sem perder a continuidade dos dados, ou seja, não é necessário definir limites rígidos para a suscetibilidade dos processos analisados. Deve-se, no entanto, verificar o grau de risco envolvido na definição dos pontos de controle utilizados que podem ser definidos por limites mais conservadores, assumindo um risco menor, contudo delimitando grandes áreas como "suscetíveis", ou menos conservadores, assumindo riscos maiores e que resultam em um número menor de áreas delimitadas como "suscetiveis".

\subsubsection{Definição dos pesos na análise}

Os pesos a serem atribuídos a cada tema utilizando a técnica de Combinação Linear Ponderada (CLP) podem ser definidos diretamente pelo analista, ou podem ser gerados com auxílio da técnica AHP (Analytical Hierarchy Process) que calcula os pesos finais através de uma lógica de comparação pareada entre os fatores utilizados, definida por Saaty (1987). Essa técnica permite estabelecer pesos relativos entre cada tema verificando a importância relativa entre cada fator, cujos pesos resultantes são 
empregados na análise multi-critério no módulo MCE (Multi-Criteria Evaluation) do Idrisi32.

O Idrisi32 apresenta um módulo especifico para o cálculo dos pesos (módulo weight) com a possibilidade de modificar os parâmetros utilizados e recalcular os pesos obtidos interativamente, apresentando uma razão de consistência da matriz, que deverá ser inferior a 0.10 . Valores iguais, ou superiores, a 0.10 indicam uma alta probabilidade de que os pesos foram atribuidos ao acaso, ou seja, aleatoriamente.

A matriz produzida para a análise de processos de movimento de massa utilizou a ponderação de importância apresentada na Tabela 7.20, que indica a importância relativa de uma variável na coluna da matriz em relação a uma variável nas linhas. A Tabela 7.21 apresenta os valores definidos e os resultados obtidos no módulo weight são apresentados na Tabela 7.22 .

Tabela 7.20 - Escala de 9 pontos de importância relativa utilizada como parâmetro para definição dos pesos entre cada fator.

\begin{tabular}{|c|c|c|c|c|c|c|c|c|}
\hline \multicolumn{9}{|c|}{ ESCALA CONTINUAA DE COMPARAÇÄO PAREADA ( 9 PONTOS) } \\
\hline $\begin{array}{l}\text { Extrema- } \\
\text { mente }\end{array}$ & $\begin{array}{c}\text { Muito } \\
\text { fortemen } \\
\text { te }\end{array}$ & Fortemente & Moderadamente & Igualmente & Moderadamente & Fortemente & $\begin{array}{c}\text { Muito } \\
\text { fortemente }\end{array}$ & $\begin{array}{l}\text { Extrema- } \\
\text { mente }\end{array}$ \\
\hline $1 / 9$ & $1 / 7$ & $1 / 5$ & $1 / 3$ & 1 & 3 & 6 & 7 & 9 \\
\hline \multicolumn{4}{|c|}{ MENOS IMPORTANTE } & IGUAIS & \multicolumn{4}{|c|}{ MAIS IMPORTANTE } \\
\hline
\end{tabular}

Tabela 7.21 - Matriz de comparação pareada produzida na análise dos processos de movimento de massa. Os elementos das linhas são comparados com os elementos das colunas, por exemplo, o fator declividade é considerado como extremamente mais importante do que o fator geologia.

\begin{tabular}{|c|c|c|c|c|c|}
\hline & Geologia & Geomorfologia & Pedologia & Declividade & Cobertura \\
\hline Geologia & 1 & & & & \\
\hline Geomorfologia & 1.5 & 1 & & & \\
\hline Pedologia & $1 / 3$ & $1 / 3$ & 1 & & \\
\hline Declividade & 9 & 7 & 9 & 1 & \\
\hline Cobertura & 7 & 7 & 7 & $1 / 2$ & 1 \\
\hline
\end{tabular}


Tabela 7.22 - Resultados da matriz de análise pareada para os processos de movimento de massa.

\begin{tabular}{|c|c|}
\hline 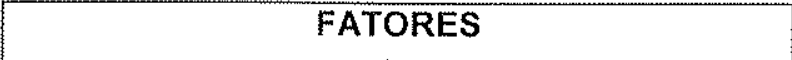 & PESOS \\
\hline Geologia & 0.0610 \\
\hline Geomorfologia & 0.0746 \\
\hline Pedologia & 0.0350 \\
\hline Declividade & 0.4890 \\
\hline Cobertura & 0.3404 \\
\hline Total & 0.9990 \\
\hline
\end{tabular}

\subsubsection{Avaliação dos resultados da análise}

A Figura 7.8 apresenta o resultado final da avaliação para processos de movimentos de massa. O resultado da análise destacou as áreas naturalmente suscetiveis, conforme os fatores principais de declividade e geomorfologia/geologia, relacionando com áreas que apresentam maior interferência antrópica, como solo exposto e campo limpo, que podem induzir a ocorrência de processos.

Algumas áreas delimitadas como de alta a muito alta suscetibilidade foram previamente visitadas em campo e são apresentadas na Figura 7.9. Os pontos apresentados na Figura 7.9 indicam alta suscetibilidade aos processos de movimento de massa, com a ocorrência de escorregamentos induzidos.

Apesar da classificação da cobertura da terra ter indicado para essa área a predominância de cobertura vegetal densa (arbórea), que tende a proteger a superfície da dinâmica superficial, o produto final da análise apresentou uma alta suscetibilidade para as áreas associadas às altas declividades, que de fato apresentaram ocorrência de escorregamentos. Também pôde ser observado que esses escorregamentos foram potencializados pela ação antrópica, devido à execução de cortes e aterros inadequados associados à concentração de águas pluviais. Mesmo com a existência de algumas obras de drenagem, como apresentado na foto do ponto C36, Figura 7.9, em que nota-se uma ruptura circular associada ao aterro da estrada, e ao fundo uma caixa de drenagem.

O ponto C37 não apresenta um plano de ruptura aparente, mas nota-se um rastejo do material que segue a direção da vertente, indicando uma ruptura plana, com grande quantidade de material instável na encosta. 


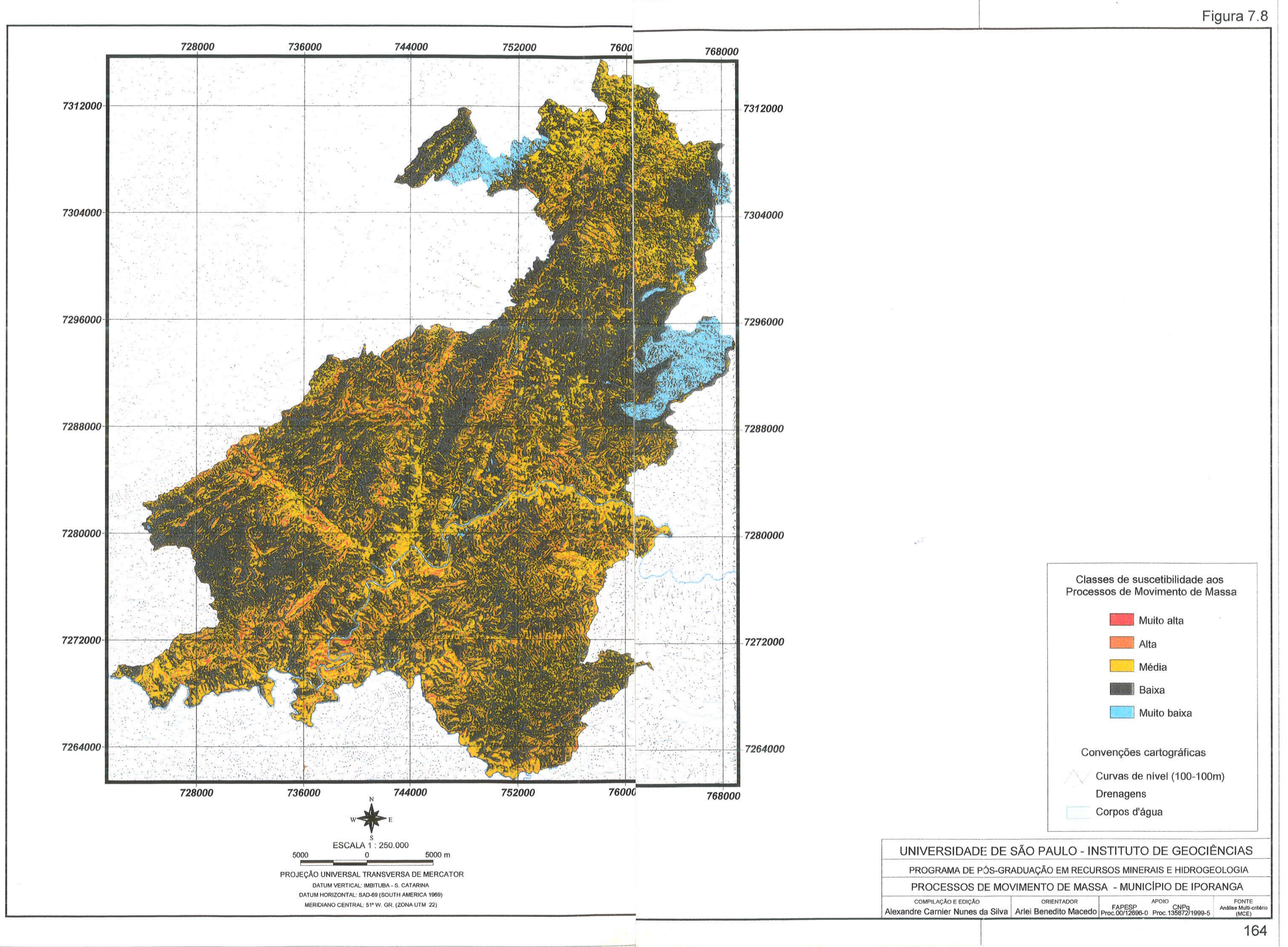



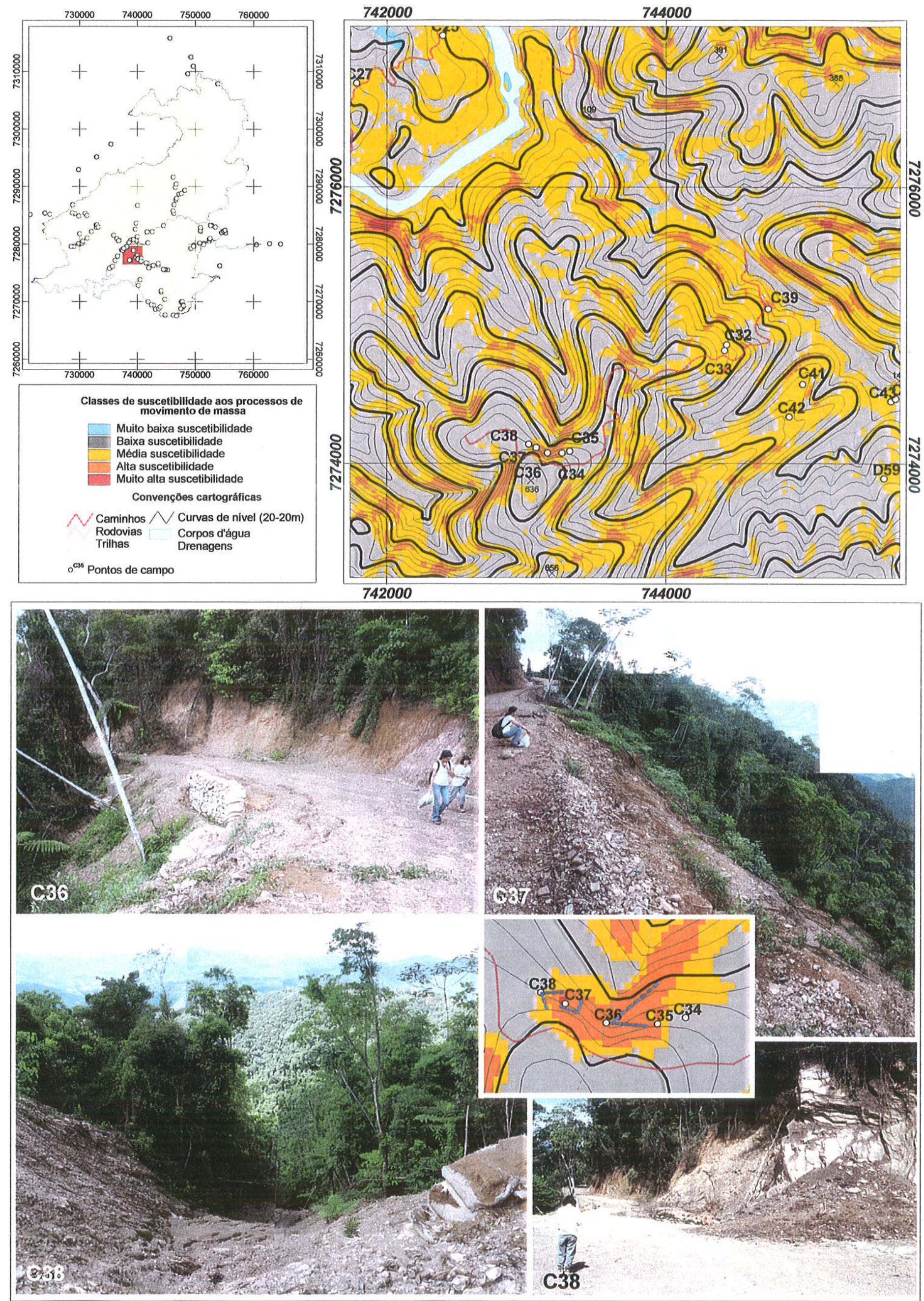

Figura 7.9 - Pontos de campo mostrando áreas de alta suscetibilidade aos processos de movimento de massa, com desenvolvimento de processos. 
O ponto C38-B apresenta um bloco de metassiltitos tombado, onde nota-se o condicionamento dos planos de fraqueza aproximadamente sub-verticais. O mesmo ponto apresenta na encosta um processo de escorregamento com superficie de ruptura aproximadamente circular, que deslocou grande quantidade de material, e que concentra grande parte das águas pluviais desenvolvendo feições erosivas de ravinamento, como pode ser observado na foto C38-A.

Outros pontos de campo também confirmaram o resultado da análise, sendo observado o desenvolvimento de movimentos de massa, o que indica que são áreas com alta suscetibilidade e que podem, ou apresentar uma evolução lenta, caso sejam mantidas as condições atuais, ou rápida, caso sofram interferências antrópicas que potencializem os processos, seja pela exposição dos materiais, seja pela concentração das águas pluviais. 


\subsubsection{Carta de suscetibilidade aos processos erosivos}

A pontuação dos mapas temáticos básicos seguiu o mesmo critério de hierarquização utilizado para a elaboração da carta de suscetibilidade aos movimentos de massa. O critério que orientou a análise é o critério de resistência dos materiais, e conseqüentemente de constituição, entendendo que as unidades mais suscetiveis seriam aquelas com menor resistência e que se apresentassem em condições topográficas favoráveis ao transporte de sedimentos (com energia de transporte).

\subsubsection{Fator geologia}

As unidades consideradas mais críticas em relação aos processos erosivos receberam a pontuação 5 (muito alta suscetibilidade), indicando que apresentam menor resistência, ou seja, seus elementos constituintes apresentam baixa resistência à desagregação. A classificação das unidades é a mesma apresentada no item 7.2.1.1, pois foram empregados os mesmos critérios da elaboração do mapa de suscetibilidade aos movimentos de massa (Tabela 7.16).

\subsubsection{Fator geomorfologia}

As unidades consideradas mais criticas em relação aos processos erosivos são aquelas que apresentam a associação de maiores amplitudes de relevo e declividade, abrangendo os sistemas de relevo do tipo escarpa e montanhas.

As demais unidades que representam associações de morros e morrotes são consideradas como de média suscetibilidade. No caso dos processos erosivos as unidades de planície fluvial e terraços são consideradas como de alta suscetibilidade, conforme apresentado na Tabela 7.17, diferindo da análise de processos de movimentos de massa, pois apesar da alta suscetibilidade associada a esses sedimentos, em ambas análises, a condição topográfica desses depósitos favorece os processos de desagregação e transporte, recebendo portanto uma alta pontuação (Tabela 7.17).

\subsubsection{Fator pedologia}

As unidades consideradas mais críticas, em relação aos processos erosivos, são aquelas que apresentam perfis de solo mais espessos e com baixa resistência.

A pontuação das unidades seguiu o mesmo critério de resistência empregado na análise para movimentos de massa, diferindo somente em relação aos solos gleizados distróficos, que foram considerados como solos de muito baixa suscetibilidade aos 
processos erosivos, pois apresentam-se saturados e em situações topográficas geralmente não favoráveis à desagregação e transporte de partículas. A Tabela 7.18 apresenta a pontuação atribuida.

\subsubsection{Fator cobertura da terra}

As unidades que proporcionam menor proteção da superficie foram consideradas as mais críticas em relação aos processos erosivos. Os critérios empregados foram os mesmos para a análise de processos de movimento de massa. A Tabela 7.19 apresenta a pontuação atribuida.

\subsubsection{Fator declividade}

O tratamento dos dados de declividade utilizou a padronização direta para o limite $0-255$, utilizando a padronização fuzzy com função sigmoidal crescente com os seguintes pontos de controle da curva (declividade em porcentagem): $a=0 \%$ e $b, c, d=20 \%$. Esses valores representam dois conjuntos hipotéticos: o conjunto das declividades que não apresentam nenhuma suscetibilidade aos processos erosivos e o limite médio de declividade, a partir do qual a suscetibilidade aos processos é elevada.

No caso dos processos erosivos é necessário considerar declividades menores, pois essas declividades estão associadas à condições de relevo mais favoráveis ao transporte de sedimentos pelo escoamento superficial, que ocorre em áreas mais planas que configuram rampas de média inclinação $\left(\sim 10^{\circ}\right)$ e proporcionam energia de transporte mais constante, fator fundamental para a instalação do processo erosivo.

\subsubsection{Definição dos pesos na análise}

Os pesos atribuidos a cada tema para utilização da técnica de Combinação Linear Ponderada (CLP) foram gerados com auxílio do módulo weight, que emprega a técnica AHP (Analytical Hierarchy Process) e calcula os pesos finais através da lógica de comparação pareada entre os fatores (conforme descrito no item 7.2.1.6). Os pesos foram calculados até que apresentassem uma razão aceitável de consistência da matriz (inferior a 0.10).

A matriz produzida para a análise de processos erosivos utilizou a ponderação de importância apresentada na Tabela 7.20 , que indica a importância relativa de uma variável na coluna da matriz em relação a uma variável nas linhas em uma escala contínua de 9 pontos. 
A Tabela 7.23 apresenta os valores definidos e a Tabela 7.24 os resultados obtidos no módulo weight.

Tabela 7.23 - Matriz de comparação pareada produzida na análise dos processos erosivos. Os elementos das linhas são comparados com os elementos das colunas, por exemplo, o fator cobertura é considerado como igualmente importante em relação ao fator declividade.

\begin{tabular}{|c|c|c|c|c|c|}
\hline & Geologia & Geomorfologia & Pedologia & Declividade & Cobertura \\
\hline Geologia & 1 & & & & \\
\hline Geomorfologia & 1.5 & 1 & & & \\
\hline Declividade & 3 & 3 & 1 & & \\
\hline Cobertura & 8 & 7 & 7 & 1 & 1 \\
\hline
\end{tabular}

Tabela 7.24 - Resultados da matriz de análise pareada para os processos de movimento de massa.

\begin{tabular}{|c|c|}
\hline FATORES & PESOS \\
\hline Geologia & 0.0381 \\
\hline Geomorfologia & 0.0474 \\
\hline Pedologia & 0.0897 \\
\hline Declividade & 0.4115 \\
\hline Cobertura & 0.4133 \\
\hline Total & 1.0000 \\
\hline
\end{tabular}

Razão de consistência $=0.04$ (Aceitável).

\subsubsection{Avaliação dos resultados da análise}

A Figura 7.10 apresenta o resultado final da avaliação para processos erosivos. O resultado da análise destacou as áreas naturalmente suscetíveis, conforme os fatores principais de declividade e cobertura da terra, relacionando com as características do meio físico definidas pelos fatores geomorfologia e geologia, em que a variável cobertura da terra constitui fator decisivo induzindo a ocorrência de processos.

Diversas áreas delimitadas como de alta a muito alta suscetibilidade foram previamente visitadas em campo e apresentam realmente o desenvolvimento de processos. situação extrema da ocorrência de processos erosivos induzidos é apresentada na Figura 7.11. Os pontos apresentados indicam alta suscetibilidade aos processos erosivos, com a ocorrência de erosão linear, como pode ser observado na foto do ponto C42-D, em que nota-se a evolução dos sulcos para ravinamento. 
Essa área é utilizada pela Prefeitura de Iporanga como área de empréstimo de material para lastro das estradas, era utilizada como lixão, como pode ser observado na foto $\mathrm{C} 41$, estando ele atualmente desativado. Geologicamente a área é constituída por metaconglomerados, metassiltitos e filitos cinzas, com intercalações de niveis mais quartzosos, associados a solos do tipo cambissolo (Ca2).

A foto $\mathrm{C} 42-\mathrm{B}$ e $\mathrm{C}$ apresentam a porção topograficamente mais baixa da área em que há desenvolvimento de erosão linear pela concentração do escoamento superficial. $\mathrm{Na}$ foto $\mathrm{C} 42 \mathrm{C}$ pode-se observar grande quantidade de blocos e sedimentos acumulados no canal.

Outros pontos de campo também confirmaram a presença de processos erosivos em áreas com alta suscetibilidade, e que da mesma forma que os processos de movimento de massa, podem apresentar aumento expressivo caso continuem a sofrer interferências antrópicas que potencializem os processos, ou seja, exponham os materiais superficiais ou concentrem as águas pluviais, sem que sejam tomadas medidas de caráter preventivo principalmente relacionadas à correção da drenagem superficial. 


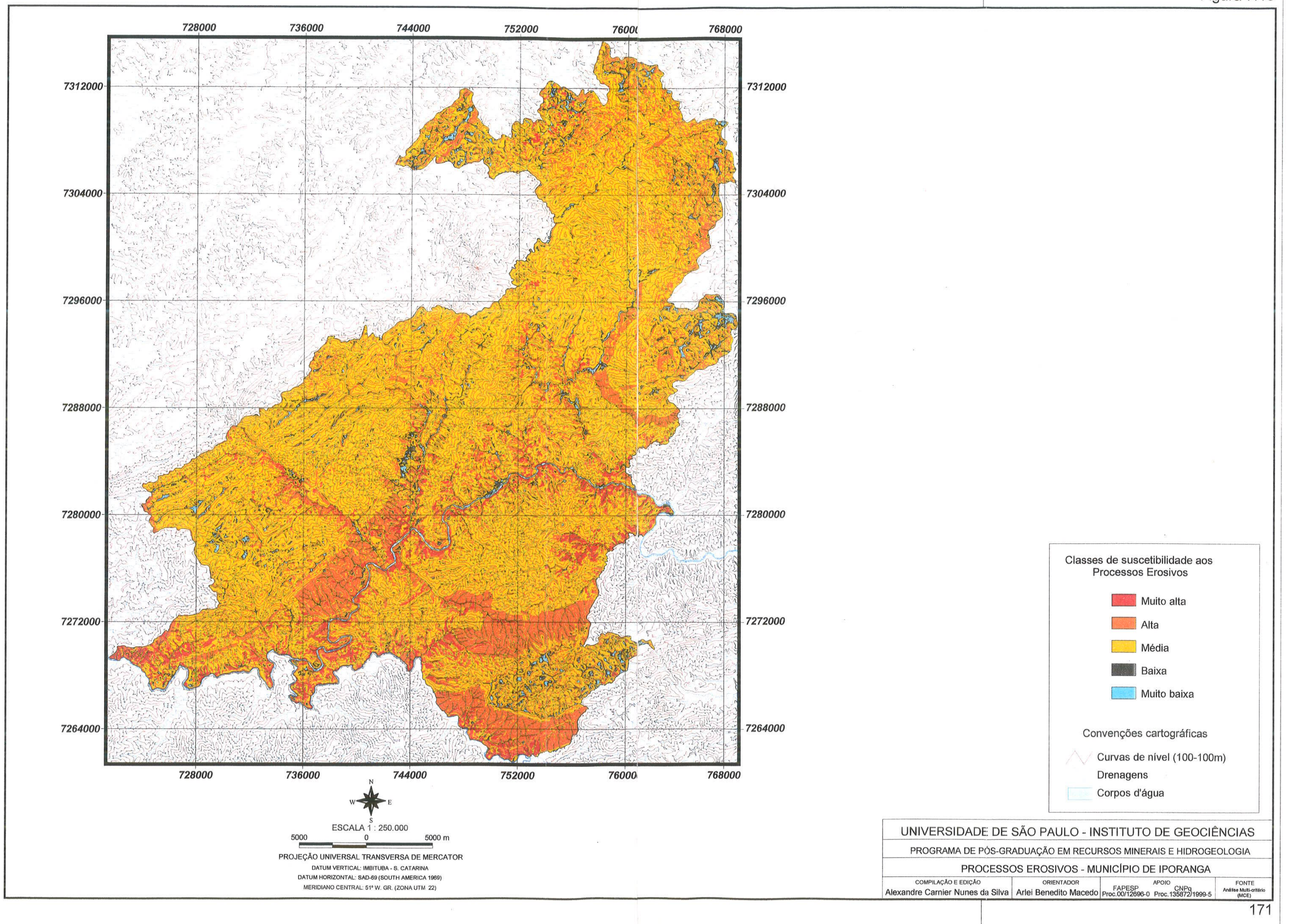




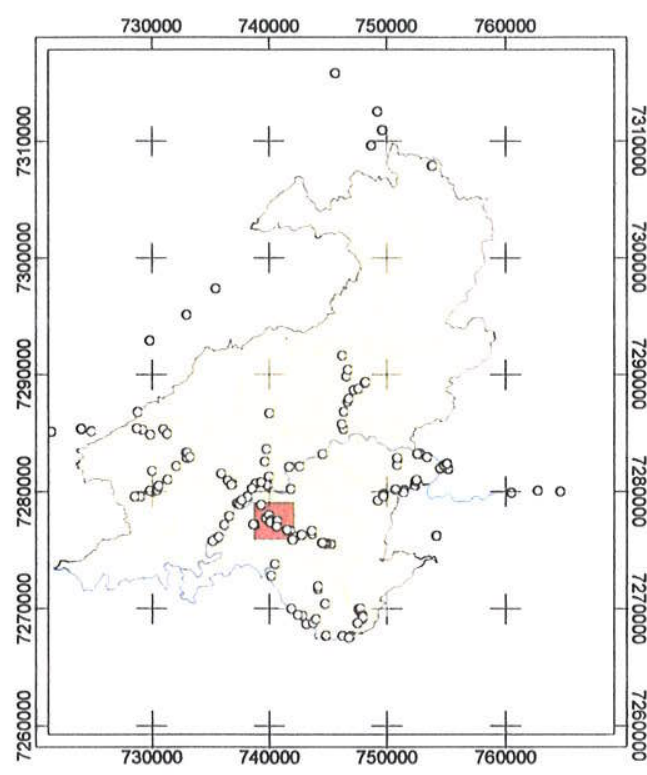
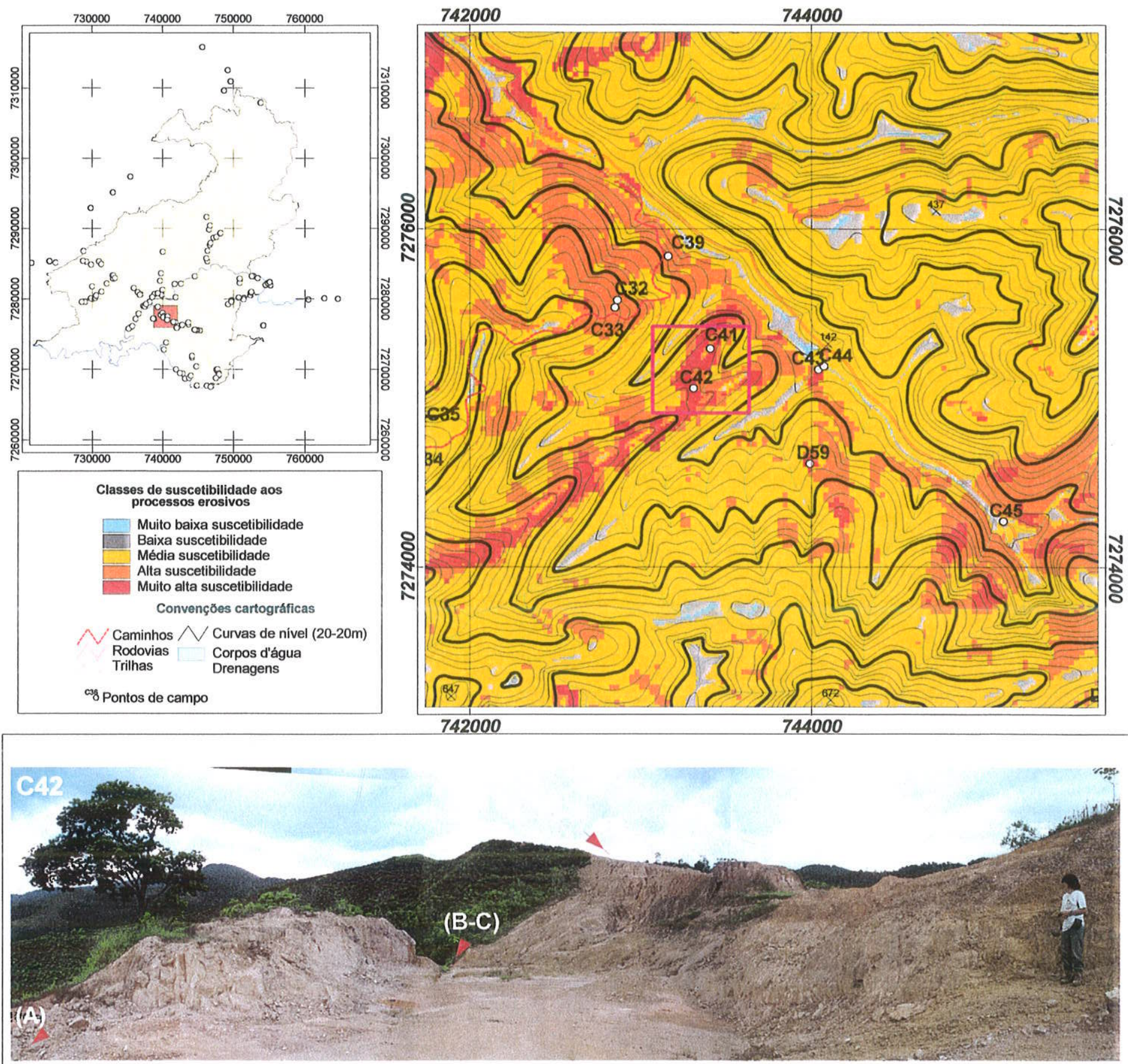

Classes de suscetibilidade aos

Muito baixa suscetibilidade

Baixa suscetibilidade

Média suscetibilidade

Alta suscetibilidade

Muito alta suscetibilidade

Convençöes cartográficas

$\checkmark$ Caminhos $\wedge$ Curvas de nível (20-20m)

Rodovias Corpos d'água

Trilhas Drenagens

ç8 Pontos de campo
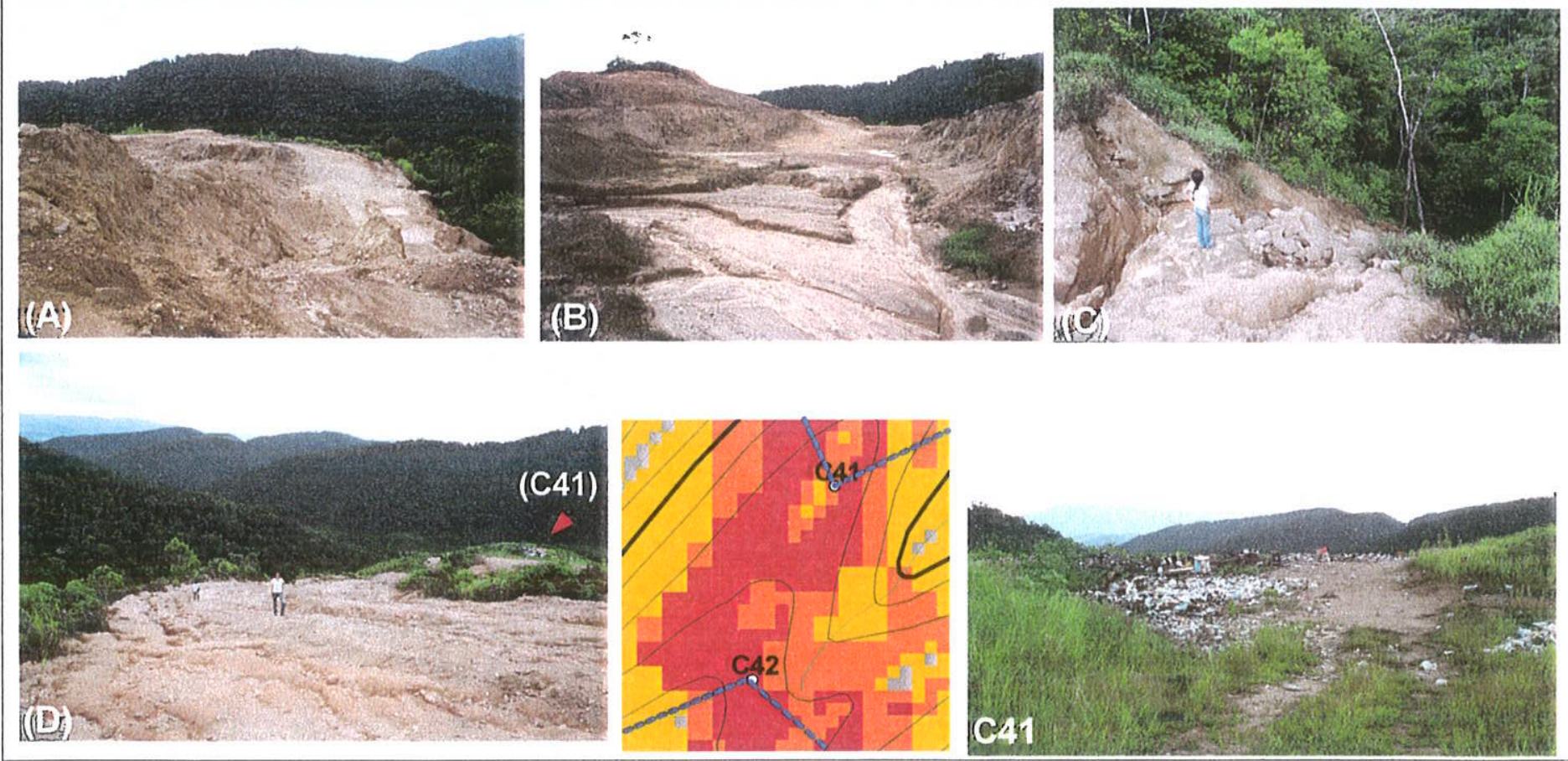

Figura 7.11 - Ponto de campo mostrando áreas delimitadas como de alta suscetibilidade aos processos erosivos, com desenvolvimento de processos. 


\subsubsection{Carta de suscetibilidade aos processos de subsidência}

O critério que orientou a análise é a constituição do material rochoso, entendendo que as unidades mais suscetiveis seriam aquelas com constituição carbonática, ou associação de litotipos diversos com rochas carbonáticas, e presença de materias inconsolidados com alto índice de vazios.

\subsubsection{Fator geologia}

As unidades consideradas mais críticas em relação aos processos de subsidência são apresentadas, na Tabela 7.25 , em uma pontuação de 0 ou 1 , indicando a existência ou não de suscetibilidade

Tabela 7.25 - Descrição das unidades geológicas críticas na análise de suscetibilidade aos processos de subsidência. A pontuação utiliza a escala 0-1.

\begin{tabular}{|c|c|c|c|}
\hline $\begin{array}{l}\text { Unidade } \\
\text { (ID) }\end{array}$ & Sigla da Unidade & Descrição da unidade geológica & $\begin{array}{l}\text { Pontuação } \\
\text { utilizada }\end{array}$ \\
\hline 1 & Qa & Aluviöes em geral e sedimentos coluviais & 1 \\
\hline 2 & TQC & Conglomerados semi-consolidados, Areias e Argilas & 1 \\
\hline 3 & $\mathrm{JKb}$ & Diques e silis de rochas básicas & 0 \\
\hline 4 & $\mathrm{CNeG}$ & $\begin{array}{l}\text { Corpos Granitoides: Alcali-sienito pórfiro, Bombas, Tonalitos e } \\
\text { Microgranitos }\end{array}$ & 0 \\
\hline 8 & NMvpM & Mármores, em geral bandados, calcíticos e dolomiticos & 1 \\
\hline 9 & NMvsA & $\begin{array}{c}\text { Metarenitos, localmente conglomeráticos com intercalaçôes de } \\
\text { Metassititos }\end{array}$ & 0 \\
\hline 10 & NMvmM & $\begin{array}{c}\text { Mármores impuros, margosos, predominantemente calciticos, cinza } \\
\text { escuros, sulfetados, com intercalações de filitos carbonáticos, } \\
\text { Metassititos e Metarenitos }\end{array}$ & 1 \\
\hline 11 & NMvmF & Filitos & 0 \\
\hline 12 & NMvaF & Filitos, Metassittitos e Metarenitos finos & 0 \\
\hline 13 & NMvbM & $\begin{array}{c}\text { Mármores impuros, margosos, predominantemente calciticos, cinza } \\
\text { escuros, sulfetados, com intercalaçoes de Filitos carbonáticos, } \\
\text { Metassiltitos e Metarenitos }\end{array}$ & 1 \\
\hline 14 & NMvbs & Metassiltitos e filitos com intercalaçǒes de metarenitos finos & 0 \\
\hline 15 & NMvbA & $\begin{array}{l}\text { Metarenitos com niveis e lentes de Metaconglomerados oligomíticos, } \\
\text { Metarenitos arcoseanos, Metarenitos com granulos e Metassiltitos e } \\
\text { flitos subordinados }\end{array}$ & 0 \\
\hline 16 & NMiA & Metarenitos e Metaconglomerados polimíticos com matriz arcoseana & 0 \\
\hline 17 & NMiF & $\begin{array}{l}\text { Metarritimitos finos, predominando Metassiltitos com intercalaçöes de } \\
\text { Metargilitos, Metarenitos metarcóseos e Filitos carbonáticos }\end{array}$ & 1 \\
\hline 18 & NMiQ & Quartzitos (Metarenitos) com intercalaçöes de Metassiltitos & 0 \\
\hline 19 & NMiC & Metaconglomerados e Metabrechas polimiticas com matriz filitica & 0 \\
\hline 20 & NMvrF & $\begin{array}{l}\text { Metarritimitos finos, predominantemente Metassiltitos finos, com } \\
\text { intercalaçסes de Metargilitos, Metarenitos, Carbonato filitos, Clorita } \\
\text { filitos, Filitos grafitosos, Mármores, Metacherts, Metatufos e Xistos } \\
\text { verdes }\end{array}$ & 0 \\
\hline 22 & NMvrFM & Carbonato filitos com bandas de Mármores & 1 \\
\hline 23 & NMvrQ & Quartzitos (Metarenitos e Metassiltitos) & 1 \\
\hline 24 & NMvrAC & Metaconglomerados oligomíticos & 0 \\
\hline 25 & NMvrFF & Formaçōes ferriferas & 0 \\
\hline 26 & MNvrR & Metargilitos e Metassiltitos finos com estrutura maciça predominante & 0 \\
\hline 27 & NMvrC & Metabasitos (Carbonato fels, Clorita milonitos) & 0 \\
\hline 28 & NMvrB & $\begin{array}{c}\text { Melabasitos (Actinolita anfibolitos, Piroxênio anfibolitos, Clorita } \\
\text { milonitos) }\end{array}$ & 0 \\
\hline 29 & NMvrFX & $\begin{array}{c}\text { Filitos e Xistos finos, por vezes com intercalações centim,tricas a } \\
\text { decimétricas de Quartzo xistos e Quartzitos }\end{array}$ & 0 \\
\hline
\end{tabular}




\begin{tabular}{|c|c|c|c|}
\hline 30 & NMvrM & Mármores & 1 \\
\hline 31 & NMvrD & Metabasitos (Hornblenda anfibolitos) & 0 \\
\hline 32 & NMvMT & $\begin{array}{l}\text { Mármores em geral dolomíticos, finos, maciços, brancos, passando } \\
\text { localmente a quartzitos e mármores cinzentos }\end{array}$ & 1 \\
\hline 33 & MNscF & Filitos cinzentos & 0 \\
\hline 34 & NMscM & $\begin{array}{l}\text { Mármores calcíticos e dolomíticos, associados por vezes a brechas } \\
\text { quartzosas finas }\end{array}$ & 1 \\
\hline 35 & NMscQ & Quartzitos & 0 \\
\hline 36 & MNsFX & $\begin{array}{l}\text { Filitos e Xistos finos, subordinadamente Quartzo-biotita-muscovita } \\
\text { xistos, Clorita xistos, Mica-quartzo xistos e Xistos grafitosos }\end{array}$ & 0 \\
\hline 37 & MNsQ & Quartzitos & 0 \\
\hline 38 & MNsMa & Mármores & 1 \\
\hline 39 & NMsAX & $\begin{array}{c}\text { (Granada)-quartzo-biotita-muscovita xistos, por vezes com estaurolita, } \\
\text { cordierita, sillimanita e plagioclásio, passando localmente a xistos } \\
\text { feldspáticos e paragnaisses }\end{array}$ & 0 \\
\hline 40 & NMsM & Mármores, em geral dolomíticos, finos, maciços e silicosos & 1 \\
\hline 41 & PgmME & $\begin{array}{l}\text { Migmatitos, predominantemente bandados, com paleossoma de biotita } \\
\text { e/ou hornblenda gnaisses, por vezes fortemente milonitizados }\end{array}$ & 0 \\
\hline 42 & NMacX & Mica-Xistos & 0 \\
\hline 43 & NmacCS & $\begin{array}{l}\text { Rochas silicáticas, cálcio xistos, mármores e intercalações } \\
\text { subordinadas de quartzos xistos }\end{array}$ & 1 \\
\hline 44 & NagG & Complexo Granitóide Indiferenciado & 0 \\
\hline 45 & $\mathrm{NmiQ}$ & Quartzitos (Metarenitos) com intercalaçöes de Metassiltitos & 0 \\
\hline 46 & NMisFX & $\begin{array}{l}\text { Filitos e xistos finos, subordinadamente quartzonbiotita-muscovita } \\
\text { xistos, clorita xistos, mica-quartzo xistos e xistos grafitosos }\end{array}$ & 0 \\
\hline
\end{tabular}

\subsubsection{Avaliação dos resultados da análise}

A Figura 7.12 apresenta o resultado da análise de áreas potencialmente suscetíveis aos processos de subsidência por afundamento cástico ou colapso de solos. As classes de ocorrência são: (1) rochas predominantemente carbonáticas; (2) rochas carbonáticas encobertas por aluviões em geral e sedimentos coluviais; (3) aluviões em geral e sedimentos coluviais, e (4) Conglomerados semi-consolidados, areias e argilas.

Essa análise tem um caráter preliminar, e identifica áreas que devem ser investigadas, caso sejam destinadas à obras de infra-estrutura básica ou assentamentos. Tais investigações devem ter como objetivo verificar as condições de sub-superfície, caracterizando, no caso das áreas cársticas, o comportamento das águas subterrâneas, carste coberto, se possivel com o uso de métodos indiretos (geofísica) e diretos (sondagens), buscando a existência de drenagens anormalmente secas, sumidouros, ressurgências, dolinas, entre outras, conforme indicado por Nakazawa et al. (1991).

No caso das áreas de aluviões, sedimentos inconsolidados e conglomerados devem-se avaliar as caracteristicas dos solos desenvolvidos sobre tais unidades que serão mais sujeitos ao adensamento, e conseqüênte subsidência, em função da capacidade de redução de volume quando submetidos ao umedecimento (Nakazawa et al., 1995). Essas características que devem ser verificadas antes da destinação de uso dessas áreas. 


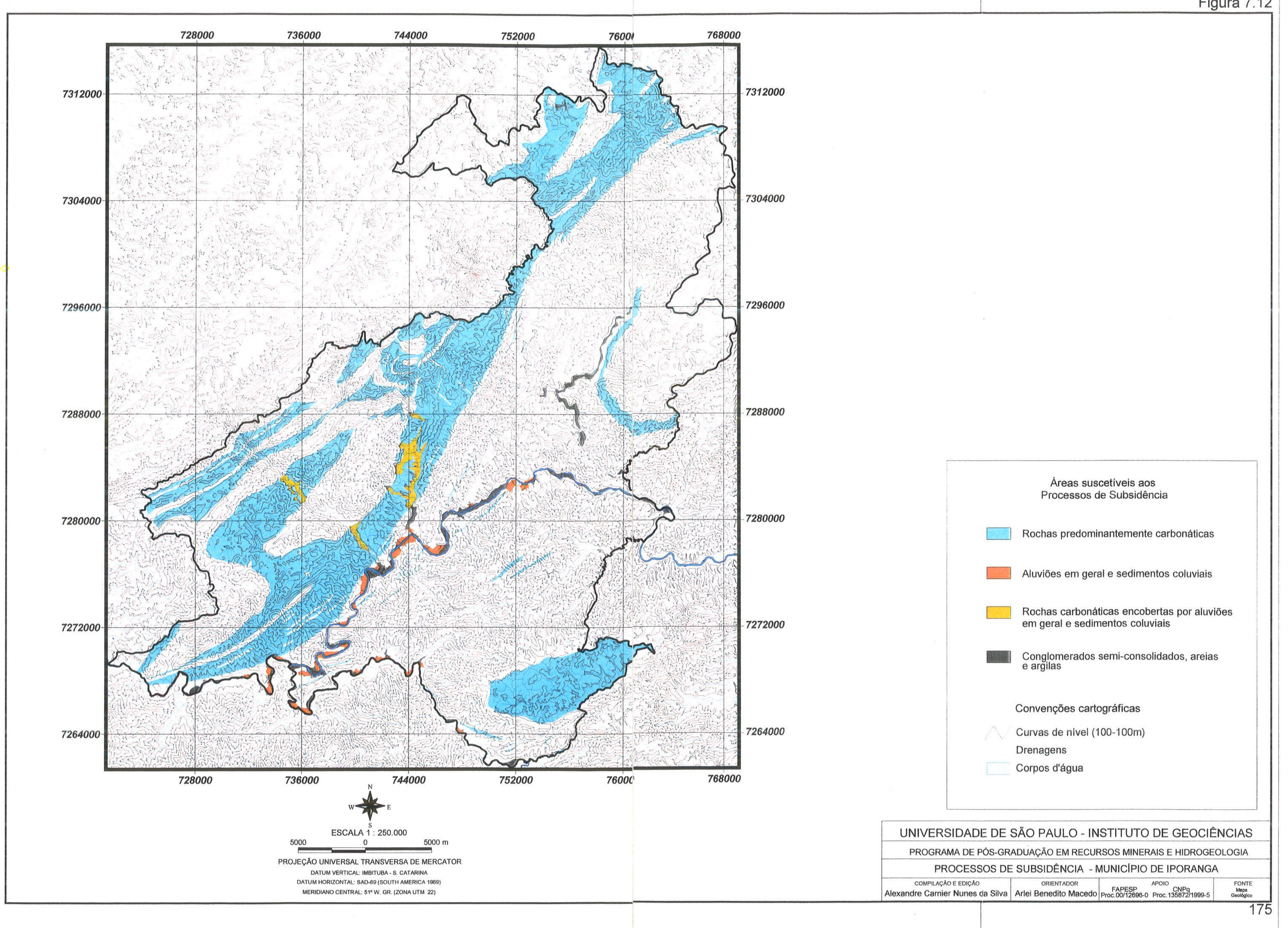




\subsubsection{Carta de aptidão aos diversos usos}

A análise de aptidão aos diversos usos leva em consideração as cartas de suscetibilidade aos processos de movimento de massa, erosão e subsidência, incluindo - cruzamento com as áreas legalmente protegidas como Parques, Zona de Vida Silvestre (APAs) e Áreas de Proteção Permanente (APP), definidas pelo Código Florestal. Outros fatores incluídos na análise são: a distância das estradas e distâncias do centro urbano de Iporanga e do Bairro da Serra, que são pontos de referência turística no município, além da cobertura da terra.

\subsubsection{Fator suscetibilidade aos processos de movimento de massa}

As unidades classificadas como mais críticas, em relação aos processos de movimento de massa, foram consideradas as menos favoráveis do ponto de vista da aptidão ao uso do solo, recebendo portanto uma pontuação inversa à análise de suscetibilidade, ou seja, as áreas com alta pontuação quanto à suscetibilidade ao processo recebem os menores valores em relação à aptidão ao uso do solo.

Essa análise valoriza as áreas que possuem um conjunto de características favoráveis à estabilidade, ou seja, alta resistência à desagregação dos materiais (rochas e solos) pelos processos da dinâmica superficial, baixo gradiente topográfico e coberturas vegetais favoráveis à proteção da superfície.

O produto da análise de suscetibilidade aos processos de movimento de massa, gerado no módulo MCE do /drisi32 (com valores de 0-255), foi utilizado como entrada no módulo Fuzzy utilizando-se a função de parametrização do tipo linear decrescente com valores de $a, b, c$ iguais a 0 e digual a 255 .

\subsubsection{Fator suscetibilidade aos processos erosivos}

As unidades classificadas como mais críticas, em relação aos processos erosivos, foram consideradas as menos favoráveis aos diversos usos do solo, recebendo as menores pontuações. Já as unidades menos suscetiveis aos processos erosivos foram consideradas as mais aptas aos diversos usos do solo.

Da mesma forma que o fator de suscetibilidade aos processos de movimento de massa, o fator suscetibilidade aos processos erosivos valoriza as áreas mais estáveis em relação aos processos de dinâmica superficial. 
O produto da análise de suscetibilidade aos processos erosivos, gerado no módulo MCE do Idrisi32 (com valores de 0-255), foi utilizado como entrada no módulo Fuzzy, utilizando-se a função de parametrização do tipo linear decrescente com valores de $a, b, c$ iguais a 0 e digual a 255 .

\subsubsection{Fator distância dos centros populacionais}

Foram considerados como centros populacionais, nessa análise, as duas áreas que concentram a maior parte do fluxo de turistas no municipio, o Bairro da Serra e a cidade de Iporanga, visando incluir na análise a tendência de crescimento destes dois núcleos populacionais do município. Esse fator representa as áreas mais próximas aos dois núcleos como áreas mais aptas e as áreas mais distantes como menos aptas, utilizando a função de parametrização sigmoidal decrescente com pontos de controle $a, b, c$ iguais a 0 e $d$ igual a maior distância aos centros populacionais, no caso $44562 \mathrm{~m}$.

\subsubsection{Fator distância das estradas}

O fator distância das estradas considerou somente as estradas principais da região de lporanga (incluindo o entorno do município), levando em consideração que as áreas mais aptas aos diversos usos seriam aquelas que se encontrassem mais próximas às estradas principais. As áreas mais próximas às estradas foram consideradas mais áptas e as áreas mais distantes como menos aptas, utilizando a função de parametrização sigmoidal decrescente com pontos de controle $a, b, c$ iguais a 0 e $d$ igual à maior distância aos centros populacionais, no caso $17482 \mathrm{~m}$.

\subsubsection{Fator cobertura da terra}

Esse fator permite considerar na análise as restrições ambientais impostas às áreas com cobertura vegetal arbórea, legalmente protegidas pelo decreto federal $n^{\circ} 750$ (10/02/1993) que proíbe o corte, a exploração e a supressão de vegetação primária ou nos estágios avançado e médio de regeneração da Mata Atlântica.

A classificação da cobertura da terra utilizada apresenta três unidades de cobertura vegetal, conforme apresentado na Tabela 7.26 , que analisadas conforme o decreto 750 corresponderiam a:

a) Vegetação de porte arbustivo: vegetação em estágio inicial de regeneração; 
b) Vegetação de porte arbóreo: vegetação primária podendo incluir fragmentos de vegetação em estágio médio ou avançado de regeneração;

c) Campo sujo ou capoeira: vegetação secundária em estágio pioneiro;

As classes de cobertura vegetal de porte arbustivo e campo sujo apresentam portanto uma menor restrição ambiental, e recebem na análise de aptidão uma alta pontuação (valor 4, na escala 0-5). A classe de cobertura vegetal arbórea, por apresentar uma alta restrição ambiental, recebeu uma pontuação muito baixa quanto a aptidão aos diversos usos (valor 1). A classe solo exposto (ou campo limpo) recebeu a pontuação mais elevada (valor 5) considerando que constituem áreas que admitem o uso direto.

Tabela 7.26 - Descrição das unidades de cobertura da terra e pontuações utilizadas na análise de aptidão.

\begin{tabular}{|c|c|c|}
\hline $\begin{array}{l}\text { Unidade } \\
\text { (ID) }\end{array}$ & Sigla / Descrição da unidade & $\begin{array}{l}\text { Pontuação utilizada na análise de } \\
\text { aptidão aos diversos usos }\end{array}$ \\
\hline 1 & C1 - Rios e corposd'água; & 0 \\
\hline 2 & $\begin{array}{c}\text { C2 - Vegetação de porte arbustivo (podendo incluir fragmentos de } \\
\text { capoeira ou campo sujo); }\end{array}$ & 4 \\
\hline 3 & C3 - Vegetação de porte arbóreo (densa) associada (ou näo) as encostas; & 1 \\
\hline 4 & C4 - Solo exposto ou campo limpo (estradas e arruamentos); & 5 \\
\hline 5 & C5 - Campo sujo ou capoeira (porte arbustivo); & 4 \\
\hline
\end{tabular}

\subsubsection{Restrições ambientais}

As unidades de conservação foram espacializadas em função dos limites dos Parques e APAs (Zona de Vida Silvestre) e das Áreas de Proteção Permanente (APPS), que funcionam como uma máscara, indicando a inaptidão dessas áreas para qualquer uso, conforme apresentado na Tabela 7.27.

Tabela 7.27 - Descrição das unidades de conservação e pontuações utilizadas na análise.

\begin{tabular}{|c|c|c|}
\hline $\begin{array}{c}\text { Unidade } \\
\text { (ID) }\end{array}$ & Sigla / Descrição da unidade & $\begin{array}{c}\text { Pontuação utilizada na análise de } \\
\text { aptidáo aos diversos usos } \\
\text { (1=Apto 0=tnapto) }\end{array}$ \\
\hline 1 & Remanescentes de quilombos & 1 \\
\hline 2 & Area de Tombamento & 1 \\
\hline 3 & APA Serra do Mar & 1 \\
\hline 4 & Parque Intervales e APA Serra do Mar & 0 \\
\hline 5 & Parque Intervales & 0 \\
\hline 6 & Parque PETAR & 0 \\
\hline 7 & Parque Estadual Jacupiranga & 0 \\
\hline 8 & APA Serra do Mar (ZVS-Zona de Vida Silvestre) & 0 \\
\hline
\end{tabular}


As áreas de proteção permanente estão definidas no Código Florestal (Lei $n^{\circ}$ 4771 - 15/09/1965, alterada pela Lei no 7.803 de 18.7.1989), reproduzida aqui parcialmente, como áreas de proteção às florestas e demais formas de vegetação natural situadas:

"...ao longo dos rios ou de qualquer curso d'água desde o seu nivel mais alto em faixa marginal cuja largura mínima será:

- de 50 (cinquenta) metros para os cursos d'água que tenham de 10 (dez) a 50 (cinquenta) metros de largura;

- de 100 (cem) metros para os cursos d'água que tenham de 50 (cinquenta) a 200 (duzentos) metros de largura;

ao redor das lagoas, lagos ou reservatórios d'água naturais ou artificiais;

no topo de morros, montes, montanhas e serras;

nas encostas ou partes destas, com declividade superior a $45^{\circ}$, equivalente a $100 \% \mathrm{na}$ linha de maior declive;

Esses parâmetros foram utilizados na elaboração das restrições ambientais utilizadas como uma máscara na elaboração da carta de aptidão aos diversos usos.

\subsubsection{Definição dos pesos na análise}

Os pesos atribuidos a cada tema para utilização da técnica de Combinação Linear Ponderada (CLP) foram gerados com auxílio do módulo weight que emprega a técnica AHP (Analytical Hierarchy Process) e calcula os pesos finais através da lógica de comparação pareada entre os fatores (conforme descrito no item 7.2.1.6). Os pesos foram calculados até que apresentassem uma razão aceitável de consistência da matriz (inferior a 0.10 ).

A matriz produzida para a análise de aptidão utilizou a ponderação de importância apresentada na Tabela 7.20, que indica a importância relativa de uma variável na coluna da matriz em relaçäo a uma variável nas linhas em uma escala contínua de 9 pontos.

A Tabela 7.28 apresenta os valores definidos e a Tabela 7.29 os resultados obtidos no módulo weight. 
Tabela 7.28 - Matriz de comparação pareada produzida na análise de aptidão. Os elementos das linhas são comparados com os elementos das colunas, por exemplo: o fator cobertura é considerado como fortemente mais importante em relação ao fator distância às estradas.

\begin{tabular}{|c|c|c|c|c|c|c|}
\hline & $\begin{array}{c}\text { Distância } \\
\text { Estradas }\end{array}$ & $\begin{array}{c}\text { Distância } \\
\text { Centros }\end{array}$ & $\begin{array}{c}\text { Baixa Susc. } \\
\text { Erosão }\end{array}$ & $\begin{array}{c}\text { Baixa Susc. } \\
\text { Mov.Massa }\end{array}$ & $\begin{array}{c}\text { Baixa Susc. } \\
\text { Subsidência }\end{array}$ & $\begin{array}{c}\text { Tipo de } \\
\text { cobertura } \\
\text { da terra }\end{array}$ \\
\hline $\begin{array}{c}\text { Distância } \\
\text { Estradas }\end{array}$ & 1 & 1 & 1 & & & \\
\hline $\begin{array}{c}\text { Distância } \\
\text { Centros }\end{array}$ & 3 & 3 & 5 & 1 & & \\
\hline $\begin{array}{c}\text { Baixa Susc. } \\
\text { Erosão }\end{array}$ & 3 & 5 & 3 & $1 / 3$ & 1 & \\
\hline $\begin{array}{c}\text { Baixa Susc. } \\
\text { Mov.Massa }\end{array}$ & 6 & 4 & 3 & 3 & 3 & 1 \\
\hline $\begin{array}{c}\text { Baixa Susc. } \\
\text { Subsidência }\end{array}$ & 4 & 6 & & & & \\
\hline $\begin{array}{c}\text { Tipo de } \\
\text { cobertura } \\
\text { da terra }\end{array}$ & 8 & & & & & \\
\hline
\end{tabular}

Tabela 7.29 - Resultados da matriz de análise pareada para a análise de aptidão aos diversos usos.

\begin{tabular}{|c|c|}
\hline$x^{2}$ & PESOS \\
\hline Distáncia Estradas & 0.0332 \\
\hline Distância Centros & 0.0529 \\
\hline Baixa Susc. Erosão & 0.0908 \\
\hline Baixa Susc. Mov.Massa & 0.2764 \\
\hline Baixa Susc. Subsidência & 0.1538 \\
\hline Tipo de cobertura da terra & 0.3929 \\
\hline Total & 1.0000 \\
\hline
\end{tabular}

Razăo de consistência $=0.07$ (Aceitável).

\subsubsection{Avaliação dos resultados da análise}

A Figura 7.13 apresenta o resultado da análise de aptidão do meio físico para os diferentes tipos de uso e ocupação do solo. As classes definidas foram (1) Áreas com muito baixa aptidão; (2) Baixa aptidão (3) Média aptidão, (4) Alta aptidão e (5) Muito alta aptidão.

A análise identificou as áreas que possuem uma associação de caracteristicas favoráveis aos diferentes tipos de uso e ocupação do solo do ponto de vista da baixa suscetibilidade que apresentam quanto ao desenvolvimento de processos da dinâmica superficial (movimentos de massa, erosão e subsidência), excluindo as áreas legalmente protegidas pela legislação estadual e federal (APP, Parques e Zona de Vida Silvestre na APA), indicando também a baixa aptidão de áreas com densa cobertura 


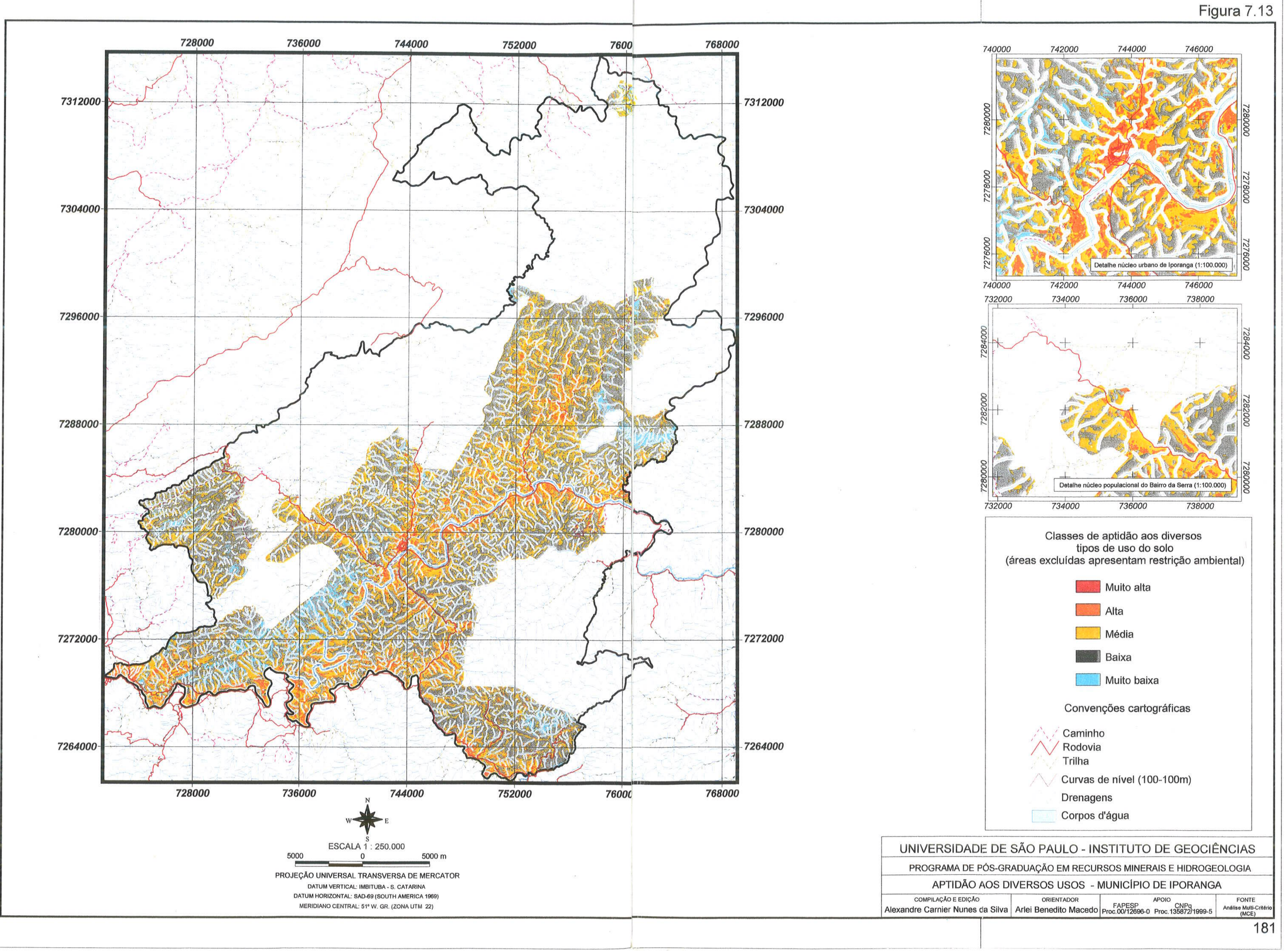


vegetal devido às restrições estabelecidas pelo decreto da Mata Atlântica (decreto federal $\mathrm{N}^{0} 750$ ).

Outro fator que poderia ter sido utilizado é a distância em relação às unidades de conservação e áreas de proteção permanente, contudo esse critério prejudicaria a avaliação de áreas aptas mais próximas ao núcleo populacional do Bairro da Serra que está localizado na borda do PETAR e apresenta uma forte tendência de crescimento, apesar da proximidade com o parque.

A destinação das áreas determinadas como Muito alta e alta aptidão aos diversos usos devem utilizar critérios que compatibilizem o uso do solo com a conservação do meio ambiente, sem causar impactos negativos ao entorno destas áreas.

\subsubsection{Comparação da aptidão aos diversos usos e capacidade de uso e aptidão agrícola}

A análise de aptidão aos diversos usos é uma indicação das áreas mais aptas aos diferentes tipos de uso e ocupação do solo em relação às condições do meio físico, frente aos processos de dinâmica superficial, levando em consideração os fatores legais e logísticos (estradas). Essa análise não incluiu a consideração de práticas agrícolas, apesar de levar em consideração a suscetibilidade aos processos erosivos, fator que integra a metodologia de análise de capacidade de uso, conforme descrito no capítulo sobre classes de capacidade de uso e niveis de manejo.

As áreas determinadas como de muito alta e alta aptidão aos diversos usos foram reclassificadas para uma única classe e cruzadas com as cartas de capacidade de uso e aptidão agrícola, resultando em 65 unidades, apresentadas na Tabela 7.30, que indica a associação existente e a expressão em área. Deve-se destacar que estas unidades representam áreas fragmentadas que foram agrupadas pelo critério de pertencerem às mesmas unidades quanto às características de aptidão agrícola e capacidade de uso, não sendo espacialmente contínuas (como pode ser observado na Figura 7.13). 
Tabela 7.30 - Unidades que representam as áreas aptas aos diversos usos do solo, nas categoras alta e muito alta, e seu relacionamento com as classes de capaciade de uso e aptidão agrícola, ordenadas por expressão em área.

\begin{tabular}{|c|c|c|c|c|c|c|}
\hline Unidades & $\begin{array}{c}\text { Área } \\
\text { (Hectares) }\end{array}$ & Relação \% & $\begin{array}{l}\text { Classe de } \\
\text { Capacidade } \\
\text { de uso }\end{array}$ & $\begin{array}{l}\text { Grupo de } \\
\text { Capacidade } \\
\text { de uso }\end{array}$ & \begin{tabular}{|} 
Subgrupos de \\
aptidão \\
agrícola
\end{tabular} & $\begin{array}{c}\text { Grupos de } \\
\text { aptidão agricola }\end{array}$ \\
\hline 1 & 0.0225 & 0.001 & Illa & A & $2 a(b c)$ & 2 \\
\hline 2 & 0.0225 & 0.001 & $\mathrm{IVe}$ & A & $5(s)$ & 5 \\
\hline 3 & 0.0450 & 0.001 & Ville & $C$ & $1 \mathrm{aBc}$ & 1 \\
\hline 4 & 0.0450 & 0.001 & Viles & $B$ & 6 & 6 \\
\hline 5 & 0.0675 & 0.002 & VI+IVes & $B$ & $3(a)$ & 3 \\
\hline 6 & 0.0675 & 0.002 & Vil+vles & B & $5(s)$ & 5 \\
\hline 7 & 0.1125 & 0.003 & Ville & C & $2 a(b c)$ & 2 \\
\hline 8 & 0.1125 & 0.003 & lla & $A$ & $5 s$ & 5 \\
\hline 9 & 0.1125 & 0.003 & IVes & $A$ & $5(s)$ & 5 \\
\hline 10 & 0.2025 & 0.006 & Vle & $B$ & $6+$ & 6 \\
\hline 11 & 0.2925 & 0.008 & VIle & $\mathrm{B}$ & $2 a(b c)$ & 2 \\
\hline 12 & 0.3600 & 0.010 & Vile & $\mathrm{B}$ & 6 & 6 \\
\hline 13 & 0.3825 & 0.011 & Viles & C & $5 s$ & 5 \\
\hline 14 & 0.4050 & 0.011 & VIlle & $\mathrm{C}$ & $2(a) b(c)$ & 2 \\
\hline 15 & 0.4500 & 0.013 & Vlles & $B$ & $1 \mathrm{aBc}$ & 1 \\
\hline 16 & 0.4500 & 0.013 & IVe & A & $4 p$ & 4 \\
\hline 17 & 0.4950 & 0.014 & $111 a$ & $A$ & $2(a) b(c)$ & 2 \\
\hline 18 & 0.7200 & 0.020 & IVes & A & 6 & 6 \\
\hline 19 & 0.7425 & 0.021 & IVes & $A$ & $2 a(b c)$ & 2 \\
\hline 20 & 1.0125 & 0.029 & Viles & $B$ & $4 p$ & 4 \\
\hline 21 & 1.1475 & 0.032 & Vle & $\mathrm{B}$ & $2 a(b c)$ & 2 \\
\hline 22 & 1.1700 & 0.033 & VI+IVes & $B$ & $1 \mathrm{aBc}$ & 1 \\
\hline 23 & 1.2150 & 0.034 & VitlVes & $B$ & $2(a) b c$ & 2 \\
\hline 24 & 1.2150 & 0.034 & Ville & C & $5(s)$ & 5 \\
\hline 25 & 1.3050 & 0.037 & IVes & $A$ & $5 s$ & 5 \\
\hline 26 & 1.3500 & 0.038 & VIle & $B$ & $4 p$ & 4 \\
\hline 27 & 1.3950 & 0.039 & illes & $A$ & $2(a) b(c)$ & 2 \\
\hline 28 & 1.4625 & 0.041 & Ville & C & $3(a)$ & 3 \\
\hline 29 & 1.7100 & 0.048 & VIlle & $\mathrm{C}$ & $1 \mathrm{aBC}$ & 1 \\
\hline 30 & 2.2500 & 0.1 & VIlle & C & 2(a)bc & 2 \\
\hline 31 & 2.4075 & 0.1 & VIl+Vles & $B$ & $4 p$ & 4 \\
\hline 32 & 2.7675 & 0.1 & IVe & A & $3(a)$ & 3 \\
\hline 33 & 3.6450 & 0.1 & IVes & $A$ & $2(a) b(c)$ & 2 \\
\hline 34 & 3.7575 & 0.1 & VII+Vles & $B$ & $5 \mathrm{~s}$ & 5 \\
\hline 35 & 4.1850 & 0.1 & VIlle & $\mathrm{C}$ & $5 s$ & 5 \\
\hline 36 & 4.3200 & 0.1 & Vitives & $B$ & $5 s$ & 5 \\
\hline 37 & 4.4550 & 0.1 & Vles & $B$ & $2(a) b(c)$ & 2 \\
\hline 38 & 5.2875 & 0.1 & VI+IVes & $\mathrm{B}$ & $5(s)$ & 5 \\
\hline 39 & 5.6925 & 0.2 & Vl+lVes & $B$ & 6 & 6 \\
\hline 40 & 10.2375 & 0.3 & Illa & $A$ & $4 p$ & 4 \\
\hline 41 & 10.4175 & 0.3 & VIIIe & C & $4 p$ & 4 \\
\hline 42 & 11.5425 & 0.3 & Vle & B & $5(s)$ & 5 \\
\hline 43 & 11.8575 & 0.3 & Villes & C & 6 & 6 \\
\hline 44 & 13.6800 & 0.4 & IVe & A & 2(a)bc & 2 \\
\hline 45 & 19.8225 & 0.6 & $\mathrm{IVe}$ & $A$ & 6 & 6 \\
\hline 46 & 20.7000 & 0.6 & Vle & A & $4 p$ & 4 \\
\hline 47 & 23.3100 & 0.7 & Vlle & $B$ & $5 s$ & 5 \\
\hline 48 & 23.5350 & 0.7 & Vle & $B$ & 6 & 6 \\
\hline 49 & 42.0525 & 1.2 & Vle & $B$ & $3(a)$ & 3 \\
\hline 50 & 46.4400 & 1.3 & IVe & $A$ & $2 \mathrm{a}(\mathrm{bc})$ & 2 \\
\hline 51 & 49.6350 & 1.4 & Vllie & $\mathrm{C}$ & $6+$ & 6 \\
\hline 52 & 56.9475 & 1.6 & IIs & $A$ & $1 \mathrm{aBC}$ & 1 \\
\hline 53 & 57.2400 & 1,6 & IIs & A & $1 \mathrm{aBc}$ & 1 \\
\hline 54 & 69.3000 & 2.0 & lis & A & 6 & 6 \\
\hline 55 & 82.0350 & 2.3 & Vlles & $B$ & $5(s)$ & 5 \\
\hline 56 & 110.5425 & 3.1 & Illa & $A$ & $2(a) b c$ & 2 \\
\hline 57 & 115.0875 & 3.3 & Vlle & $B$ & $5(s)$ & 5 \\
\hline 58 & 123.9075 & 3.5 & IIIa & A & 6 & 6 \\
\hline 59 & 175.2525 & 5.0 & Vie & $B$ & $5 s$ & 5 \\
\hline 60 & 239.4675 & 6.8 & VItlves & $B$ & $4 p$ & 4 \\
\hline 61 & 2164.2525 & 61.2 & VIlle & $C$ & 6 & 6 \\
\hline
\end{tabular}

As unidades com mais de 1 hectare, unidades 20 ate 61 , representam $98 \%$ do total, sendo que dessa parcela $15.2 \%$ (538 hectares) constituem unidades do grupo $\mathrm{A}$ de capacidade de uso, ou seja, terras próprias para culturas anuais, perenes, pastagem 
e/ou reflorestamento; $21.6 \%$ (744 hectares) constituem áreas do grupo $\mathrm{B}$, terras impróprias para culturas mas ainda próprias para pastagem e/ou reflorestamento; e $63.2 \%$ (2247 hectares) correspondem a terras impróprias para culturas, pastagem ou reflorestamento.

\subsubsection{Análise dos títulos minerários}

O município de Iporanga apresenta 113 processos ativos atualmente (abril/2002) conforme listagem do Cadastro Mineiro disponível na Internet (DNPM, 2002). A tabela 7.31 apresenta a sintese da situação dos processos, na fase atual dos empreendimentos.

Tabela 7.31 - Relação de processos ativos (abril/2002) e situação do empreendimento mineral.

\begin{tabular}{|c|c|c|c|}
\hline Fase atual & $\begin{array}{l}\text { Número de } \\
\text { processos }\end{array}$ & & Substâncias \\
\hline \multirow{4}{*}{$\begin{array}{l}\text { Autorização de } \\
\text { Pesquisa }\end{array}$} & \multirow{4}{*}{39} & 23 & Calcário \\
\hline & & 5 & Chumbo \\
\hline & & 5 & Ouro \\
\hline & & 6 & Outros (barita, zinco, fluorita, caulim, manganês) \\
\hline \multirow{2}{*}{$\begin{array}{c}\text { Concessão de } \\
\text { Lavra }\end{array}$} & \multirow{2}{*}{18} & 15 & Calcário (calcário/chumbo/mármore) \\
\hline & & 3 & Chumbo (ouro/prata) \\
\hline \multirow{3}{*}{ Disponibilidade } & \multirow{3}{*}{7} & 5 & Calcário \\
\hline & & 1 & Chumbo \\
\hline & & 1 & Ouro \\
\hline $\begin{array}{c}\text { Requerimento de } \\
\text { Lavra }\end{array}$ & 5 & 5 & Calcário \\
\hline \multirow{3}{*}{$\begin{array}{c}\text { Requerimento de } \\
\text { Pesquisa }\end{array}$} & \multirow{3}{*}{45} & 34 & Calcário \\
\hline & & 4 & Ouro \\
\hline & & 6 & Outros (arsênio, cobre, granada, ilmenita, titânio) \\
\hline
\end{tabular}

Fonte: DNPM(2002)

Entre os processos ativos (considerando também as áreas em disponibilidade) 82 têm como substância mineral de interesse o calcário, destes 15 apresentam concessão de lavra e 5 encontram-se em processo de requerimento de lavra. Outros 3 processos apresentam concessão de lavra para chumbo.

Esse quadro permite verificar a tendência de crescimento do setor de mineração de minerais não-metálicos, ou minerais industriais. Essa área apresenta um grande crescimento nos últimos anos devido à crescente demanda do setor de construção civil, principalmente da indústria de cimento. 
Conforme destacado no histórico do município (item 3.1.2.2) a região não apresenta atualmente nenhuma mineração de chumbo em atividade, sendo que a mineração Furnas foi a última a paralizar suas atividades em 1992.

As concessões de lavra destes empreendimentos vem sendo continuamente renovadas junto ao DNPM, pela empresa responsável Plumbum Mineração e Metalurgia, estando parte dessa áreas dentro dos limites do Parque Estadual Turistico do Alto Ribeira (Figura 7.14). 


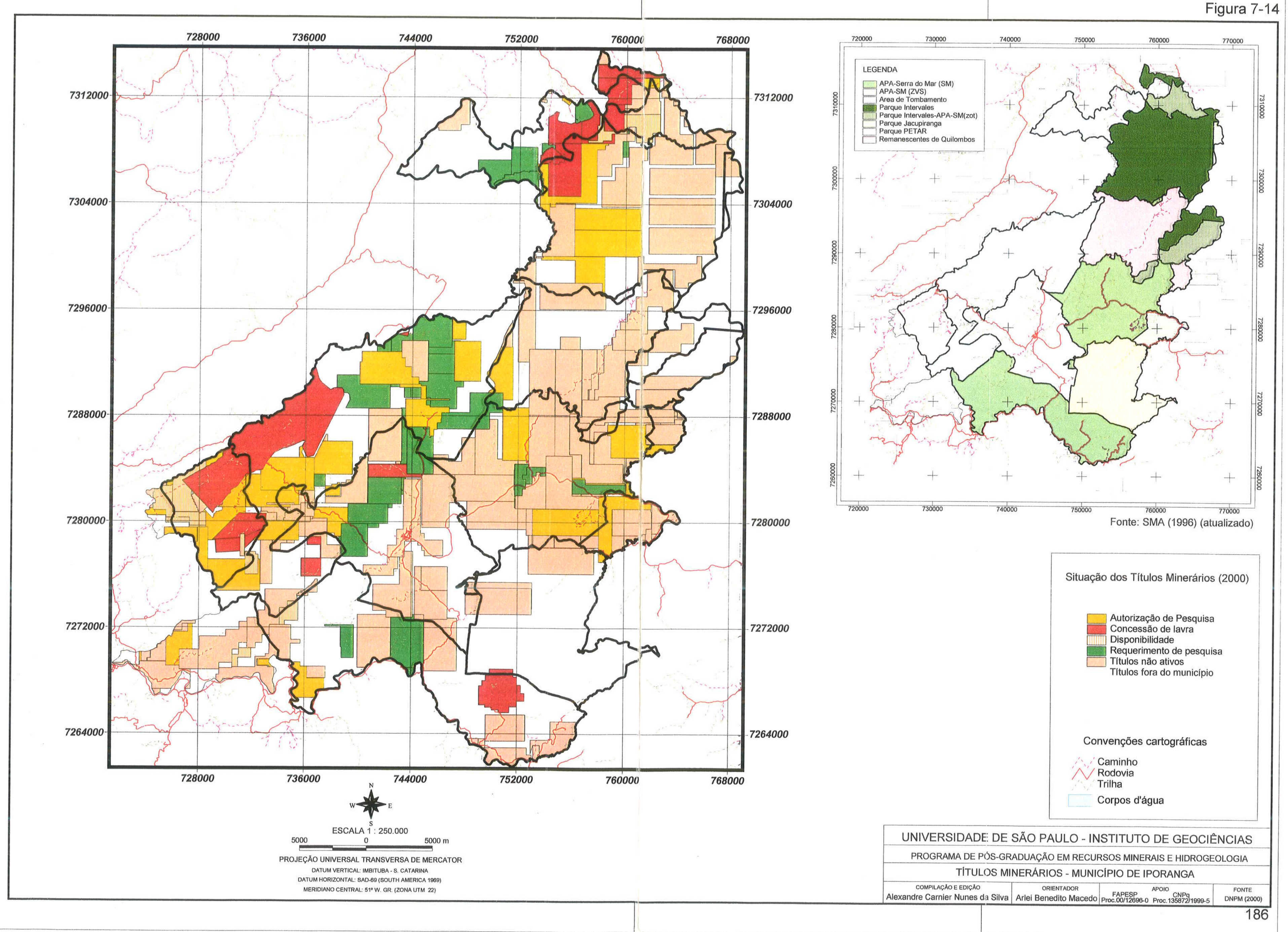




\section{CAPÍTULO 8 - CONCLUSÕES}

As técnicas de geoprocessamento e sensoriamento remoto, aplicadas neste trabalho, permitiram a organização e análise de um banco de dados georreferenciado, possibilitando a caracterização do meio físico e de suas inter-relações com as diferentes formas de cobertura da terra, e as restrições ambientais, fornecendo subsídios às ações de planejamento territorial do município de Iporanga.

As cartas de suscetibilidade aos movimentos de massa, processos erosivos e análise de aptidão aos diversos usos foram produzidas com o emprego da técnica de análise multi-critério (MCE - Multi Criteria Evaluation), com a combinação de fatores pelo método de ponderação linear (WLC - Weighted Linear Combination). Essa técnica mostrou-se adequada aos objetivos propostos permitindo a utilização dos mapas temáticos compilados, na forma de fatores, que descrevem as características condicionantes de cada processo.

A utilização da técnica AHP (Analytical Hierarchy Process), na ponderação dos fatores, constituiu uma importante ferramenta de apoio ao processo de definição dos pesos, permitindo a verificação da consistência quanto à importância atribuída a cada um dos fatores empregados.

Essa abordagem segue o método multi-temático, ou paramétrico, que apresenta as seguintes vantagens: permite a análise dos dados de cada tema de forma contínua, agregando as informações de cada tema, sem a necessidade de uma nova interpretação dos dados em relação aos limites de unidades, interpretadas em imagens de satélite; ponderação diferenciada para cada tema, baseada na análise dos fatores condicionantes do processo de dinâmica superficial analisado; integração dos dados via sistema de informações geográficas permitindo a repetição das análises com modificação dos parâmetros utilizados até que se obtenham resultados mais adequados às condições da área;

A abordagem de sistema de terrenos, ou análise integrada, emprega a definição de unidades territoriais básicas, interpretadas em imagens de satélite. Esta abordagem apresentaria vantagens operacionais, quando empregada em escalas mais regionais (1:100.000 a 1:250.000), em áreas com carência de informações sobre o meio físico, que admitem uma simplificação dos dados para a realização das análises, perdendo em alguns casos as características de continuidade dos dados e considerando na análise final uma importância igual de cada tema para a classificação final da área, 
geralmente feita pela somatória das pontuações atribuidas à unidade em cada um dos temas.

A carta de suscetibilidade aos processos de subsidência, produzida com a análise dos dados de geologia, indica as áreas mais suscetíveis aos processos por apresentar áreas de ocorrência de rochas de constituição carbonática, materiais inconsolidados com altos índices de vazios, e materiais inconsolidados sobre rochas carbonáticas. A delimitação destas unidades foi considerada suficiente para a análise em questão entendendo que estas áreas, determinadas como suscetíveis, devem ser alvo de estudos mais detalhados de campo conforme o uso previsto.

Os processamentos dos dados de sensoriamento remoto foram fundamentais nas análises de suscetibilidade e evolução da cobertura da terra. A imagem do satélite Landsat-7 (ETM+), mostrou-se útil na caracterização dos tipos de cobertura da terra presentes no município de Iporanga, apresentando melhor qualidade, em relação à do satélite Landsat-5 (TM), quanto à documentação e calibração dos dados.

O mapa de cobertura da terra, gerado com a classificação não-supervisionada, constituiu um dos fatores de maior importância nas análises por multi-critérios. As classes utilizadas permitiram a delimitação das áreas em que ocorre maior interferência antrópica, ou baixa densidade de cobertura vegetal, condições mais favoráveis à ocorrência dos processos de dinâmica superficial.

A evolução da cobertura da terra foi determinada pơr tabulação cruzada entre os mapas levantados nos períodos analisados (1990-2000). Também foram assim comparados os mapas de aptidão aos diversos usos do solo, em relação às classes de aptidão agrícola, apresentando pequenas da área do município como adequadas para produção agrícola (532 ha) ou para expansão urbana (3534 ha).

O cruzamento das análises de suscetibilidade com os mapas de cobertura da terra, e restrições ambientais, apoiada pelos sistemas de informações geográficas, mostrou-se uma técnica indispensável às atividades de planejamento territorial, permitindo a composição de cenários indicando as alternativas de uso e ocupação do solo para o município de lporanga.

A análise da evolução da cobertura da terra permitiu caracterizar as áreas com conflitos quanto ao uso do solo nas unidades de conservação, indicando que os principais conflitos existentes são atividades de mineração no interior de parques e redução da cobertura vegetal.

A análise dos títulos minerários revelou um aumento na procura dos bens minerais não-metálicos (calcário) e existência de conflitos significativos nas áreas do entorno e no interior do PETAR e Parque Estadual Intervales, onde ocorrem títulos de 
concessão de lavra e manifesto de mina. Os demais processos, dentro das unidades de conservação, apresentam-se em fase de autorização e requerimento de pesquisa, devendo passar por diversas etapas de análise dos órgãos de controle ambiental e minerário, dificilmente obtendo licença de instalação e concessão de lavra.

A análise da evolução dos dados de cobertura da terra, entre os anos de 1990 a 2000 , indica uma regeneração da cobertura vegetal em $23 \%$ da área do município (27658,5 ha), e degradação em 4\% (3926,7 ha).

Em relação às partes que sofreram redução da cobertura vegetal, 14,7\% (577,3 ha) apresentam-se em áreas não delimitadas como unidades de conservação, $26,5 \%$ (1040,6 ha) em áreas com alguma restrição ambiental (remanescentes de quilombos e áreas de tombamento), 39,3\% (1543,1 ha) em áreas de proteção ambiental (APA), e $19,5 \%$ (765,7 ha) em áreas com elevada restrição ambiental (Parques e APA-ZVS).

Em relação às partes que apresentaram recuperação da cobertura vegetal, $8,8 \%$ (2434 ha) apresentam-se em áreas não delimitadas como unidades de conservação, $27,3 \%(7550,7$ ha) em áreas com alguma restrição ambiental (remanescentes de quilombos e áreas de tombamento), 27,2\% (7523,1 ha) em áreas de proteção ambiental (APA), e 36,7\% (10150,7 ha) em áreas com elevada restrição ambiental (Parques e APA-ZVS).

A análise da localização espacial das áreas com degradação da cobertura vegetal, localizadas em grande parte ao redor dos principais núcleos populacionais de Iporanga, associada com a evolução dos dados demográficos, confirmam o aumento da área urbana do município, e conseqüentemente da população urbana nos últimos 10 anos, e a redução geral da população. As áreas em regeneração indicam terrenos que foram continuamente abandonados nos últimos anos, principalmente a partir da efetivação da regulamentação fundiária dos Parques (PETAR e Intervales) e do aumento das restrições às atividades extrativistas e agrícolas dos moradores, associados à intensificação da fiscalização dos órgãos ambientais no período.

As técnicas de geoprocessamento e sensoriamento remoto empregadas mostraram-se adequadas para a realização de diagnósticos e prognósticos integrados. Os produtos de sensoriamento remoto podem ser atualizados periodicamente, e integrados novamente à base de dados, resultando em um sistema dinâmico de apoio ao planejamento territorial, permitindo aos gestores públicos conhecer as fragilidades e potencialidades das diferentes regiões municipais, numa perspectiva de desenvolvimento sustentável, com melhoria das condições de vida da população e de conservação do meio ambiente. 
As análises produzidas apresentam o quadro geral de suscetibilidade do meio físico e indicam áreas mais aptas aos diversos usos. A destinação de uso destas áreas deve ser devidamente avaliada quanto às necessidades do município. As áreas mais aptas ao uso agrícola devem ser priorizadas para este fim, dada a pequena parte do município que apresenta alguma aptidão. As áreas restantes devem ser criteriosamente analisadas quanto ao tipo de destinação. Algumas áreas indicadas como de alta aptidão aos diversos usos constituem áreas já ocupadas, que não foram consideradas como restrição, pois grande parte da área urbana não se apresenta totalmente consolidada e admite o aproveitamento de espaços mal utilizados. A realização de obras de engenharia, de qualquer porte, nas áreas definidas como aptas aos diversos usos, deve passar por ensaios de caracterização dos materiais superficiais e avaliação das limitações conforme a destinação de cada área. 


\section{REFERÊNCIAS}

Araújo, C.C. 1999. Aplicação de geoprocessamento na análise de favorabilidade para mineralizações de chumbo, zinco e cobre nas folhas Cerro Azul e Apiaí, Vale do Ribeira, (SP e PR). São Paulo, 151p. Dissertação (Mestrado) - Instituto de Geociências, Universidade de São Paulo.

ATUS-INPE. 2000. Informações sobre os dados de calibração radiométrica do satélite Landsat 5. [on line].<atus@ltid.inpe.br>. Nov. 2000.

Augusto Filho, O. 1992. Escorregamentos em encostas naturais e ocupadas: análise e controle. In: Bitar, O.Y. (coord.). 1995. Curso de Geologia Aplicada ao Meio Ambiente. São Paulo, ABGE, IPT-DIGEO. p. 77-100.

Augusto Filho, O. 1994. Cartas de riscos de escorregamentos: uma proposta metodológica e sua aplicação no município de l/habela, SP. São Paulo, 168p. Dissertação (Mestrado) Engenharia Civil, Escola Politécnica, Universidade de São Paulo.

Baker, V.R.; Kochel, R.C. e Patton, P.C. 1988. Flood geomorphology. New York: John Wiley.

Barbosa, A.F. e Guimarães, J.E.P. 1946. Contribuição ao conhecimento da província metalogenética da região da Ribeira, Estado de São Paulo, Brasil. In: Congresso Panamericano de Engenharia de Minas e Geologia, 2, Petrópolis, Anais, p. 35-100.

Barbosa, O. 1941. Geologia e petrologia na região de Apiai, Estado de São Paulo. São Paulo. Tese para concurso da cadeira de "Geologia, Petrografia e mineralogia". Escola Politécnica, Universidade de São Paulo (inédito).

Barbosa, O. 1948. A chamada Série Ribeira. Min.Metal. v.13, n. 79, p. 187-189.

Barreto, C.N.G.B. 1988. A ocupação do pré-colonial do Vale do Ribeira de Iguape, SP: os sitios concheiros do médio curso. São Paulo. Dissertação (Mestrado). Museu de Arqueologia e Etnologia, Universidade de São Paulo.

Bigarella, J.J. e Salamuni, R. 1956a. Estudos preliminares na Série Açungui. V. Estruturas organógenas nos dolomitos da Formação Capiru (Estado do Paraná). Dusenia v. 7, n. 6 , p. $317-323$.

Bigarella, J.J. e Salamuni, R. 1956b. Estudos preliminares na Série Açungui. VII. Algumas estruturas singenéticas nos dolomitos da Formação Capiru. Arq. Biol. Tecnol. v. 11, p. 197-205.

Bigarella, J.J. e Salamuni, R. 1958a. Contribuição à geologia da região sul da Série Açungui (Estado do Paraná). Boletim Paulista de Geografia v. 29, p. 1-14.

Bigarella, J.J. e Salamuni, R. 1958b. Estudos preliminares na Série Açungui. VIII. A Formação Votuverava. Boletim Geologia, Curitiba, Instituto de História Natural, v. 2, 6p.

Bigarella, J.J. et al. 1955. Estudos preliminares na Série Açungui IV. Conglomerado do Cerne. Arq. Biol. Tecnol., IBPT. Curitiba v. 10, 245-251p.

Bitar, O.Y. e Ortega, R.D. 1998. Gestão ambiental. In: Oliveira, A.M.S. e Brito, S. N. A. Geologia de Engenharia, São Paulo-ABGE, Cap. 32, p. 499-508. 
Bitar, O.Y.; Cerri, L. E. S. e Nakazawa, V. A. 1992. Carta de risco Geológico e Carta Geotécnica: uma diferenciação a partir de casos em áreas urbanas no Brasil. In: Simpósio Latino Americano sobre Risco Geológico Urbano, 2, Pereira, Colômbia, Anais, p. $35-41$.

Bonham-Carter, G.F. 1996. Geographic Information Systems for Geoscientists: Modelling with GIS. Ottawa, Pergamon, $398 \mathrm{p}$.

Borin, Jr. T., Pinto, G.C., Silva, A.A.G.P., Morgental, A., Castro, V.T.S. 1980. Mineralizações filoneanas polimetálicas contendo ouro e prata, associadas a metais básicos descobertos pelo Projeto Eldorado, Vale do Ribeira, São Paulo. In: Congresso Brasileiro de Geologia, 31, Camboriú. Anais, SBG, v.2, p.725-742.

Brasil. Leis, decretos, etc. Lei ${ }^{\circ} 9985$ de 18 de julho de 2000. Diário Oficial da União de 19 de julho de 2000. Brasília, Presidência da República, 2000. p.1-6. Regulamenta o artigo $225, \S 1^{\circ}$, incisos I, II, III e IV da Constituição Federal, institui o Sistema Nacional de Unidades de Conservação da Natureza e dá outras providências.

Burrough, P. A. 1986. Principles of Geographical Information System for Land Resources Assessment. Oxford, Clarendon. 191p.

Burton, R.F. 1868. Viagem do Rio de Janeiro ao Morro Velho. Série Reconquista do Brasil. São Paulo, Itatiaia. v. $36,366 \mathrm{p}$.

Calógeras, P. 1904-1905. As Minas do Brasil e sua legislação. Rio de Janeiro.

Campanha, G.A. da C.; Bistrichi, C.A.; Almeida, M.A. de 1987. Considerações sobre a organização litoestratigrágfica e evolução tectônica da Faixa de Dobramentos Apiaí. In: Simpósio Sul-Brasileiro de Geologia, 3, Curitiba, Atas, v. 2, p. 725-742.

Campanha, G.A.C. 1991. Tectônica Proterozóica no Alto e Médio Vale do Ribeira, Estados de São Paulo e Paraná. São Paulo, 296 p. Tese (Doutorado) - Instituto de Geociências,
Universidade de São Paulo.

Campanha, G.A.C. 2000. Análise da cinemática, nivel crustal e fluxo de fluidos das zonas de cisalhamento da porção meridional da Faixa Apiai. São Paulo, (Relatório Final, Processo FAPESP 96/5648-1).

Campanha, G.A.C. e Sadowski, G.R. 1999. Tectonics of the Southern Portion of the Ribeira Belt (Apiaí Domain). In: Precambrian Research, v. 98, n. 1, p. 31-51. Amsterdam.

Campanha, G.A.C.; Gimenez A.F.; Caetano, S.L.V.; Pires, F.A.; Dantas, A.S.L.; Teixeira, A.L.; Dehira, L.K. 1986. Geologia e estratigrafia da região das Folhas Iporanga e Gruta do Diabo, Vale do Ribeira, São Paulo. In: Congresso Brasileiro de Geologia, 34, Goiânia, Anais, v. 2, p. 1058-1073.

Campanha, G.A.C.; Gimenez, A.F.; Caetano, S.L.V.; Pires, F.A.; Dantas, A.S.L.; Teixeira, A.L. e Dehira, L.K. 1985. Geologia das folhas Iporanga (SG.22-X-V-2) e Gruta do Diabo (SG.22-X-B-VI-1), Estado de São Paulo. São Paulo, Contrato IPT/Pró-Minério (IPT.
Relatório, 22.352).

Campos Neto, M. da C. 1983. Contribuição à litoestratigrafia do Grupo Açungui no sudeste do Estado de São Paulo. In: Simpósio Regional de Geologia, 4, São Paulo, Atlas, p. 103-
112. 
Carril, L.F.B. 1995. Terras de Negros no Vale do Ribeira: Territorialidade e Resistência. São Paulo. Dissertação (Mestrado) - Faculdade de Filosofia, Letras e Ciências Humanas, Universidade de São Paulo.

Cerri, L.E.S. 1990. Carta Geotécnica: contribuições para um concepção voltada as necessidades brasileiras. In: Congresso Brasileiro de Geologia de Engenharia, 6.; Congresso Brasileiro de Mecânica dos solos e fundações, 9., Salvador, ABGE/ABMS, Anais, p. 309-318.

Cerri, L.E.S. 1993. Riscos geológicos associados a escorregamentos: uma proposta para a prevenção de acidentes. Rio Claro, 197p. Tese (Doutorado) - Instituto de Geociências, Universidade Estadual Paulista.

CETEC, 2000. Situação dos recursos hidricos do Ribeira de Iguape e Litoral Sul - UGRHI 11. Lins, CETEC, $324 \mathrm{p}$.

CGG - Comissão Geográphica e Geológica do Estado de São Paulo. 1914. Exploração do Rio Ribeira de Iguape. $2^{a}$ ed. São Paulo, Typographica Brazil de Rotschild e Co. $34 p$.

Chavez, P.S. 1988. An Improved Dark-Object Subtraction Technique for Atmospheric Scattering Correction of Multispectral Data. Remote Sensing of Environment v. 24, p. 459-479.

Chavez, P.S. 1989. Radiometric Calibration of Landsat Thematic Mapper Multispectral images. Photogrammetric Engineering and Remote Sensing v. 55, n. 9, p. 1285-1294.

Chiodi Filho, C. 1984. Contribuição à geologia sul paulista e leste paranaense: Grupos Açungui e Setuva. In: Congresso Brasileiro de Geologia, 33, Rio de Janeiro, Anais, v. 5, p. 23942406.

Chiodi Filho, C.; Santos, J.F; Soares, P.C., Moretzjohn, J.S. 1989. Estudo de ETR para caracterização e avaliação metalogenética de granitóides no escudo paranaense. In: Congresso Brasileiro de Geoquímica, 2, Rio de Janeiro, Anais.

Christofoletti, A. 1981. Geomorfologia fluvial. São Paulo, Edgard Blücher.

Cowen, David J. 1988. GIS versus CAD versus DBMS: What Are the Differences? Photogrammetric Engineering and Remote Sensing v. 54, n. 11, p. 1551-1555.

CPRM - Cia. de Pesquisa de Recursos Minerais. 1986. Projeto Pilões. São Paulo. CPRM/SUREG SP (Relatório Final de Pesquisa/inédito).

Crepani, E.; Medeiros, J. S.; Azevedo, L. G.; Hernandez Filho, P.; Florenzano, T. G. e Duarte, V. 1996. Curso de sensoriamento remoto aplicado ao zoneamento ecológicoeconômico. São José dos Campos, Instituto Nacional de Pesquisas Espaciais, 18p.

Crepani, E.; Medeiros, J. S.; Azevedo, L. G.; Hernandez Filho, P.; Florenzano, T. G. e Duarte, V. 1998. Curso de sensoriamento remoto aplicado ao zoneamento ecológicoeconômico. Instituto Nacional de Pesquisas Espaciais. No prelo.

Crósta, A. P. 1992. Processamento digital de imagens de sensoriamento remoto. Campinas, IG/UNICAMP, 170p.

Cruden, D.M. 1990. Suggested nomenclature for a landslide summary. Bull. IAEG, v. 41, p. 1316.

Daitx, E.C. 1980. Prospecto de Cu, Pb e Zn nas faixas carbonáticas Furnas Lajeado, $S P$ e PR. São Paulo, CPRM. 27p. (Relatório final/inédito). 
Daitx, E.C. 1996. Origem e evolução dos depósitos sulfetados tipo Perau ( $P b-Z n-A g)$, com base nas jazidas de Canoas e Perau (Vale do Ribeira, PR). Rio Claro, 453 p. il. Tese (doutorado) - Instituto de Geociências e Ciências Exatas, Universidade Estadual Paulista.

Daitx, E.C. et al. 1983. Projeto Anta Gorda, mapeamento geológico da área norte, fase III. São Paulo, convênio DNPM/CPRM (inédito).

Dantas, A.S.L.; Gimenez Filho, A.; Nagata, N; Fernandes, L.A; Teixeira, A.; Frasca, M.H.B. de 1987. Evolução Geológica e Estrutural da Faixa Costeira nas regiões de Juquiá e Miracatu, Sul do Estado de São Paulo. In: Simpósio Regional de Geologia, 6, Rio Claro, Atas, p. 173-198.

Davis, J.C. 1986. Statistics and data analysis in Geology. 2 ed. New York, John Wiley.

De Blasis, P.A.D. 1988. A ocupação do pré-colonial do Vale do Ribeira de lguape, SP: os sítios liticos do médio curso. São Paulo, Dissertação (Mestrado) - Museu de Arqueologia e Etnologia, Universidade de São Paulo.

Dias, M.V.F. e Salazar Jr., O. 1987. Geologia da Seqüência Antinha - Grupo Açungui, PR. In: Simpósio Sul Brasileiro de Geologia, 3, Curitiba, Atas, v. 1, p. 263-279.

DNPM - Departamento Nacional de Produção Mineral. 2002. Cadastro minerário. [on line]. $<$ http://www.dnpm.gov.br/sicom/sicom.asp>. Mar. 2002.

DNPM/CPRM - Departamento Nacional de Produção Mineral/Cia. de Pesquisa de Recursos Minerais. 1982. Projeto Eldorado. São Paulo. (Relatório Integrado Final de Pesquisa). CPRM/SUREG-SP.

Eastman, J.R. 1997. Idrisi for Windows, User's Guide, version 2.0. Clark Labs for Cartographic Technology and Geographic Analysis, Clark University, Worcester, USA.

Eastman, J.R., Weigen, J., Kyem, P.A.K. e Toledano, J. 1995. Raster Procedures for MultiCriteria/Multi-Objective Decisions. Photogrammetric Engineering \& Remote Sensing $\mathrm{v}$. 61, n. 5, p. $539-547$.

ESRI - Environmental Systems Research Institute Inc. 1997. Arc/lnfo data management concepts, data models, database design, and storage. EUA, Environmental Systems Research Institute, 389p.

FAO. 1976. A framework for land evaluation. Roma, FAO. e Wageningen, ILRI, 72p.

Fassbinder, E. 1996. A unidade Água Clara no contexto do Grupo Açungui: um modelo transpressivo de colisão obliqua no Neoproterozóico paranaense. São Paulo, Tese (Doutorado) - Instituto de Geociências, Universidade de São Paulo.

Ferraz, J.S. 1945. Vias de comunicação para o Vale do Ribeira. São Paulo, Brasiliense.

Figueiredo, L.A.V. 2000. "O 'meio ambiente' prejudicou a gente...": politicas públicas e representações sociais de preservação e desenvolvimento; desvelando a pedagogia de um conflito no Vale do Ribeira (Iporanga-SP). Campinas, 489 p. Dissertação (Mestrado) - Faculdade de Educação, Universidade Estadual de Campinas.

Fiori, A.P. 1990. Tectônica e estratigrafia do Grupo Açungui a norte de Curitiba. São Paulo, 246 p. Tese (Livre-Docência) " Instituto de Geociências, Universidade de São Paulo. 
Fiori, A.P. 1992. Tectônica e estratigrafia do Grupo Açungui, PR. Boletim /G-USP série científica, v. 23, p. 55-74.

Fiori, A.P., Fassbinder, E., Gois, J.R. e Fumagalli, C.E. 1987b. Compartimentação tectônica do grupo Açungui a norte de Curitiba. Simpósio Sul-brasileiro de Geologia 3. Curitiba. Atas.
SBG. vol. 1. p.183-196.

Fiori, A.P., Fumagalli, C.E., Gois, J.R. e Salamuni, E. 1987a. As principais estruturas dobradas do Grupo Açungui na região de Rio Branco-Bocaiúa do Sul. Simpósio Sul-brasileiro de Geologia 3. Curitiba. Atas. SBG. vol. 1. p.281-301.

Fiori, A.P., Salamuni, E. e Fassbinder, E. 1987c. Geologia da região de Batéias-Bocaiúva do Sul. Simpósio Sul-brasileiro de Geologia 3. Curitiba. Atas. SBG. vol. 2. p.773-787.

Gimenez Filho, A. 1993. Evolução do Complexo Granítico de Três Córregos, a noroeste de Apiai - SP. São Paulo, 118p. Dissertação (Mestrado) - Instituto de Geociências, Universidade de São Paulo. Godoy, J.F. 1978. A provincia de São Paulo: trabalho estatisitco, histórico e noticioso. São
Paulo, Gov.Estado.

Godoy, J.R.L. 2001. Estrutura e composição especifica da Mata Atlântica secundária de encosta sobre calcário e filito, no Parque Estadual Turistico do Alto Ribeira, Iporanga, SP. São Paulo, 57p. Dissertação (Mestrado) - Instituto de Biociências, Universidade de São Paulo.

Goraieb, C.L. 1995. Aspectos geológicos e metalogenéticos do maciço Correas. São Paulo, 150p. Dissertação (Mestrado) - Instituto de Geociências, Universidade de São Paulo (inédito).

Guidicini, G. e Nieble, C.M. 1976. Estabilidade de taludes naturais e de escavação. São Paulo, Edusp/Edgard Blücher, 170p.

Guimarães Filho, H.A. 1994. Metodologias para intercâmbio de dados entre programas de $C A D D, S G B D, P D I$ e $S G I$ em projetos de exploração mineral. Campinas, $118 \mathrm{p}$. Dissertação (Mestrado) - Universidade Estadual de Campinas.

Guimarães, J.E.P. 1981. Epítome da história da mineração no mundo antigo, no Brasil e nos Estados Unidos da América: valores de seus defeitos e de suas personagens, sua dependência com a natureza. São Paulo, Secretaria de Estado da Cultura.

Guptill, S.C e Morrison, J.L. 1995. Elements of spatial data quality. Elsevier Sci., U.K. 78p. II.

Hardy, R.L. 1971. Multiquadric Equations of Topography and Other Irregular Surfaces. Jour. Geophys. Res., v. 76, p. 1905-1915.

Hasui, Y. 1986. Novo modelo geológico do Vale do Ribeira. São Paulo, IPT (IPT. Relatório, 23.742).

Hasui, Y. e Oliveira, M.A.F. 1984. Provincia Mantiqueira - setor central. In: Almeida, F.F.M. de, Hasui, Y. (eds.). O Pré-Cambriano do Brasil. São Paulo, Edgard Blücher, 378p.

Hasui, Y. e Sadowski, G.R. 1976. Evolução geológica do Pré-Cambriano na Região Sudeste do Estado de São Paulo. Rev. Bras. Geociências v. 6, n. 3, p. 182-200.

Hogan, D.J.; Cunha, J.M.P.; Baeninger, R. e Carmo, R.L. (orgs.). 2000. Migração e Ambiente em São Paulo: Aspectos relevantes da dinâmica recente. Unicamp, Campinas, $518 p$.

Hudson, N. 1971. Soil consenvation. New York, Cornell University Press. 302p. 
Hutchinson, M. F. 1996. A locally adaptive approach to the interpolation of digital elevation models. In: Proceedings, Third International ConferenceNWorkshop on Integrating GIS and Environmental Modeling, Santa Fe, NM. Santa Barbara, CA: National Center for Geographic Information and Analysis. [on line] <http://www.ncgia.ucsb.edu/ conf/SANTA_FE_CD-ROM/sf_papers/hutchinson_michael_dem/local.html>Abr. 2001.

Infante Jr., N. e Fornasari Filho, N. 1998. Processos de Dinâmica Superficial, Capitulo 9, em Geologia de Engenharia, ABGE, São Paulo, SP.

IPT - Instituto de Pesquisas Tecnológicas do Estado de São Paulo S.A. 1999. Carta de risco de escorregamentos e inundações de Caraguatatuba, SP. São Paulo (Relatório $n^{\circ}$ 39878/99).

ITESP - Instituto de Terras do Estado de São Paulo. 2000. Negros do Ribeira: reconhecimento étnico e conquista do território. Andrade, T., Pereira, C.A.C. e Andrade, M.R.O (eds.). São Paulo, Páginas e Letras. 195p.

JICA-MMAJ/DNPM-CPRM. 1982. Report on geological survey of Anta Gorda, Brazil: Phase /I. Acordo Coop. Tecn. Brasil-Japão, DNPM/MMAJ, Tokyo, 119 p. (inédito).

JICA-MMAJ/DNPM-CPRM. 1983. Report on geological survey of Anta Gorda, Brazil: Phase III. Acordo Coop. Tecn. Brasil-Japão, DNPM/MMAJ, Tokyo, 111 p. (inédito).

JICA-MMAJ/DNPM-CPRM. 1984. Report on geological survey of Anta Gorda, Brazil: Phase IV. Acordo Coop. Tecn. Brasit-Japão, DNPM/MMAJ, Tokyo, 57 p. (inédito).

JICA-MMAJ/DNPM-CPRM.1981. Report on geological survey of Anta Gorda, Brazil: Phase I. Acordo Coop. Tecn. Brasil-Japão, DNPM/MMAJ, Tokyo, 79 p. (inédito).

José, E. e Miranda, O. 1989. Lamarca: o capitão da guerrilha. $12^{\circ}$ ed. São Paulo, Global.

Krug, E. 1908. A Ribeira de Iguape (Die Ribeira von Iguape). São Paulo, Typographia Brazil de Rothschild and Co.

Krug, E. 1913. Xiririca: Evaporundyba e Yporanga. Rev. Inst. Hist. Geog. de São Paulo v. 17, p. 295-312, São Paulo, Typographia do "Diário Official".

Krug, E. 1939. A Ribeira de Iguape. Boletim Agricultura, Secretaria da Agricultura, Industria e Comércio do Estado de São Paulo, série 39.

Leonardos, O.H. 1934. Nota sobre a geologia do distrito de Iporanga, SP. Rio de Janeiro (DNPM. Relatório, 564).

Leonardos, O.H. 1941. Notas petrográficas sobre a Série Ribeira do Sul do Estado de São Paulo. São Paulo, Faculdade de Filosofia, Ciências e Letras - USP, p. 7-13. (Boletim, 21. Mineralogia, 4).

Lepsch, I. F. (coord.). 1991. Manual para levantamento utilitário do meio físico e classificação de terras no sistema de capacidade de uso. Sociedade Brasileira de Ciência do Solo, Campinas, São Paulo. 175p.

Lepsch, I. F., Saraiva, I.R., Donzeli, P.L., Marinho, M. de A., Sakai, E., Guillaumon, J.R., Pfeifer, R.M., Mattos, I.F. de A., Andrade, W.J. de, Silva, C.E.F. 1990. Macrozoneamento das terras da região do Rio Ribeira de Iguape, SP. Boletim Científico, v. 19, 181 p. Instituto Agronômico de Campinas, Campinas/SP. 
Lillesand, T.M. e Kiefer, R.W. 1994. Remote sensing and image interpretation. 3.ed. New York, John Wiley e Sons. $733 \mathrm{p}$.

Liotte, S.V. 2000. Utilização de técnicas de geoprocessamento para apoio ao planejamento físico-territorial do município de Pariqüera-Açu/SP. São Paulo, $170 \mathrm{p}$. Dissertação (Mestrado) - Instituto de Geociências, Universidade de São Paulo.

Marini, O.J. e Bigarella, J.J. 1967. Rochas calcárias do Grupo Açungui. Boletim Paranaense de Geociências v. 23-25, p. 105-150.

Marini, O.J.; Trein, E; Fuck, R.A. 1967. O Grupo Açungui no Estado do Paraná. Boletim Paranaense de Geociências v. 23-25, p. 43-104.

Martinez, M.C. 1995. A ação governamental e a resistência camponesa no Vale do Ribeira1968/1986. São Paulo. Dissertação (Mestrado) - Faculdade de Filosofia, Letras e Ciências Humanas, Universidade de São Paulo.

Mayer, L.M. 1990. Introduction to quantitative geomorphology: an exercise manual. New Jersey, Prentice Hall, 380p.

Mello, I.S. de C. 1995. Geologia e estudo metalogenético do Maciço ltaoca, Vale do Ribeira, SP e PR. São Paulo, 168 p. Tese (Doutorado) - Instituto de Geociências, Universidade de São Paulo.

Mitasova, H. e Mitas, L. 1993. Interpolation by Regularized Spline with Tension: I. Theory and Implementation. Mathematical Geology, v. 25, n. 6, p. 641-655.

Morgental, A., Paiva, I.P., Borin Jr., T., Pinto, G.G. e Carmo, L.S. 1981. Pesquisa de ouro no Vale do Ribeira - Atuação da CPRM. In: Simpósio Regional de Geologia, 3, Curitiba, Anais, SBG, v. 1, p 56-70.

Nakazawa, V.A.; Prandini, F.L. e Diniz, N.C. 1991. Subsidências e colapsos de solo em áreas urbanas. In: Bitar, O.Y. (org.). 1995. Curso de Geologia Aplicada ao Meio Ambiente. São Paulo, ABGE, IPT-DIGEO. p.101-133.

Nestlehner, A.A. 1979. Iporanga - presenvação. Mogi das Cruzes. Trabalho de Conclusão de curso de graduação - Faculdade de Arquitetura e Urbanismo, Brás Cubas.

Nogueira, S.A.A. 1990. Estudo das mineralizações filoneanas auriferas do depósito de Piririca, Vale do Ribeira, SP. São Paulo, 91p. Dissertação (Mestrado) - Instituto de Geociências, Universidade de São Paulo (inédito).

Novo, E. M. L. M. 1989. Sensoriamento remoto, principios e aplicações, 2. ed. São Paulo. Edgard Blücher. 308p.

Nunes da Silva, A.C. 1998. Análise de dados geológicos por geoprocessamento visando apoio à decisão na administração de recursos minerais e prospecção regional - folha lporanga a 1 : 50.000 (SG. 22-X-B-V-2). São Paulo, 55p. Monografia (Trabalho de Formatura) Instituto de Geociências, Universidade de São Paulo.

Oliva, A.; Lino, C.F. e Costa Neto, J.B. 1999. Documentos Básicos para o Plano de Manejo Parque Estadual do Alto do Ribeira/PETAR. São Paulo. (Relatório).

Pedro, M.F. 1999. Criação da carta geotécnica do municipio de Pariqüera-Açu (SP) utilizando. se análises realizadas em um sistema de informações georreferenciadas (S/G). São Paulo, 59 p. Monografia (Trabalho de Formatura) - Instituto de Geociências, Universidade de São Paulo. 
Peralta, 1963. Guia para los reconocimentos de conservación y classificatión de la capacidade de la tierra. Santiago, Min. Agricultura y Pesca. Direción de Agricultura y Pesca. Dep. Conservatión y Assistencia Técnica. 63p.

Petri, S. e Suguio, K. 1969. Sobre os metassedimentos do extremo sul do Estado de São Paulo. São Paulo, convênio USP/DAEE (Publicação especial).

Petrone, P. 1966. A baixada do Ribeira. São Paulo, USP, Boletim 283, Cadeira de Geografia, $n^{\circ} 14$.

Pires, F.A. 1988. Uma nova concepção para os ambientes do Grupo Açungui, na região de Iporanga e Apiaí, sul de São Paulo. In: Congresso Brasileiro de Geologia, 35, Belém, Anais, v. 2, p. 606-616.

Pressinotti, P.C. 1992. Análise regional e distrital de áreas potenciais a mineralizações de Sn e W: proposição de um método exploratório aplicado ao sudeste paulista. São Paulo, 183p. Dissertação (Mestrado) - Instituto de Geociências, Universidade de São Paulo.

Ramalho Filho, A.; Pereira, E.J. e Beek, K.J. 1978. Sistema de avaliação da aptidão agrícola das terras. Brasilia, SUPLAN/MA SNLCS/EMBRAPA, 70p.

Reis Neto, J.M. 1994. Faixa Itaiacoca: registro de uma colisão entre dois blocos continentais no Neoproterozóico. São Paulo, 253 p. Tese (Doutorado) - Instituto de Geociências, Universidade de São Paulo.

Ridente Jr., 2000. Prevenção e Controle da Erosão Urbana: Bacia do Córrego do Limoeiro e Bacia do Córrego do Cedro, Municipios de Presidente Prudente e Álvares Machado, SP. Rio Claro. Dissertação (Mestrado) - Instituto de Geociências e Ciências Exatas, Universidade Estadual Paulista.

Ross, J.L.S. 1990. Geomorfologia ambiente e planejamento. São Paulo, Contexto.

Ross, J.L.S. 1992. O Registro Cartográfico dos fatos Geomórficos e a Questão da Taxonomia do Relevo. Revista do Depto de Geografia FFLCH-USP v. 6, p. 17-30.

Ross, J.L.S. 1994. Análise Empírica da Fragilidade dos Ambientes Naturais e Antropizados. Revista do Depto de Geografia FFLCH-USP v. 8, p. 63-74.

Ross, J.L.S. 1995. Análises e Sínteses na Abordagem Geográfica do Planejamento Ambiental. Revista do Depto de Geografia FFLCH-USP v. 9, p. 65-76.

Saaty, R.W. 1987. The analytic hierarchy process-what it is and how it is used. Mathematical Modeling v. 9, n. 3, p. 161-176.

Salomão, F.X.T. e Iwasa, O.Y. 1995. Erosão e ocupação rural e urbana. In: Bitar, O.Y. (Coord.). 1995. Curso de Geologia Aplicada ao Meio Ambiente. São Paulo, ABGE, IPT-DIGEO. p.31-57.

SEADE - Fundação Sistema Estadual de Análise de Dados. 2002. Perfil Municipal e dados demográficos de Iporanga. [on line].<http://www. seade.gov.br>. Mar. 2002.

Shepard, D. 1968. A two dimensional interpolation function for irregularly spaced data. In: American Association for Computing Machinery National Conference, 23. Proceedings p. 517-524.

Shimada, H., (coord.) 1999. Contribuição ao conhecimento do meio físico no Parque Estadual Turístico do Alto Ribeira - PETAR (Apiai e lporanga - SP). São Paulo, Instituto Geológico-SMA, 241 p. 
Siga Jr.; Basei, M.A.S.; Reis Neto, J.M.; Machiavelli, A. e Harara, O.M. 1995. O Complexo Atuba: um cinturão paleoproterozóico intensamente retrabalhado no Neoproterozóico. Boletim IG-USP Série Cientifica v. 26, p. 69-98.

Silva, A. 1999. Evolução Geológica da Bacia de São Paulo: Contribuição da Aquisição Geofísica. São Paulo, Tese (Doutorado) - Instituto Astronômico e Geofísico, Departamento de Geofísica, Universidade de São Paulo.

Silva, A.T.S.F. e Algarte, J.P. 1981a. Contribuição à geologia da Seqüência Turvo-Cajati entre - Rio Pardo e Pariquera-Açu, Estado de São Paulo. 1. Litologia e petrografia. In: Simpósio Regional de Geologia, 3, Curitiba, Atas, v. 1, p. 109-120.

Silva, A.T.S.F. e Algarte, J.P. 1981b. Contribuição à geologia da Seqüência Turvo-Cajati entre - Rio Pardo e Pariquera-Açu, Estado de São Paulo. 2. Estrutura, metamorfismo e evolução tectônica. In: Simpósio Regional de Geologia, 3, Curitiba, 1981. Atas, v. 1, p. $121-132$

Siqueira, A.D. 1999. Metodologia de análise de dados cartográficos e de sensoriamento remoto no diagnóstico da preservação da cobertura vegetal em regiões montanhosas. São José dos Campos. Dissertação (Mestrado) - Instituto Nacional Pesquisas Espaciais.

SMA - Secretaria do Meio Ambiente do Estado de São Paulo. 1996. Proposta de Macrozoneamento do Vale do Ribeira. Relatório final. São Paulo.

Sociedade Brasileira de Espeleologia - SBE. Cadastro Nacional de Cavernas. [on-line] $<$ http://www.sbe.com.br/cnc_form.asp>. Abr. 1999.

Sousa, C.J.S. 1998. Carta de vulnerabilidade à erosão como subsidio ao zoneamento ecológico econômico em área intensamente antropizada. São José dos Campos, 172p. Dissertação (Mestrado) - Instituto Nacional de Pesquisas Espaciais.

Souza, I.M. 1972. Mineralogia da jazida de cobre do Ribeirão do Perau, Paraná. São Paulo, 213 p. Tese (Doutorado) - Instituto de Geociências, Universidade de São Paulo.

Spoladore, A. 1993. Caracterização da história deformacional das rochas proterozóicas da região de Bromado, Paraná. Rio Claro, 157 p. Dissertação (Mestrado) - Instituto de Geociências e Ciências Exatas, Universidade Estadual Paulista.

Spörl, C. 2001. Análise da fragilidade ambiental relevo-solo com aplicação de três modelos alternativos nas altas bacias do Rio Jaguari-Mirim, Ribeirão do Quartel e Ribeirão da Prata. São Paulo, 160 p. Dissertação (Mestrado) - Faculdade de Filosofia, Letras e Ciências Humanas, Universidade de São Paulo.

Teixeira A.L.A.; Moretti, E. e Christofoleti, A. 1992. Introdução aos Sistemas de Informação Geográfica, Rio Claro. 80p.

Teixeira, W. 1982. Projeto Radambrasil. Folhas SG21 - Assuncion, SG.22 - Curitiba e SG.23 Iguape. Considerações sobre os dados radiométricos: interpretação e evolução geocronológica. Brasilia, Ministério das Minas e Energia.

Theodorovicz, A., Câmara, M.M., Takahashi, A.T., Moraes, S.M. e Godoy, H.K. 1988. Geologia do Pré-Cambriano das folhas Engenheiro Maia e Ribeirão Branco, SãoPaulo. In: Congresso Brasileiro de Geologia, 35, Belém, Anais. SBG v. 6, p. 2713-2726.

Tricart J. 1977. Ecodinâmica, Rio de Janeiro, IBGE-SUPREM, 91 p. (recursos Naturais e Meio Ambiente). 
Van Westen, C. J. 1993. GISSIZ: Training package for geographic information systems in slope instability zonation. Volume 1-Theory: International Institute for Aerospace Survey and Earth Sciences (ITC) Publications $n^{\circ} 15,245 p$

Vedovello, R. 2000. Zoneamentos Geotécnicos Aplicados à Gestão Ambiental, a partir de Unidades Básicas de Compartimentação - UBCs. Rio Claro, 154 p. Tese (Doutorado) Instituto de Geociências e Ciências Exatas, Universidade Estadual Paulista.

Vedovello, R. e Mattos, J.T. 1998. A Utilização de Unidades Básicas de Compartimentação (UCBs) como base para a definição de Unidades Geotécnicas a partir de Sensoriamento Remoto. In: Simpósio Brasileiro de Cartografia Geotécnica, 3 , Florianópolis, CD-ROM, ABGE.

Wadge, G., 1988, The potential of GIS modeling of gravity flows and slope instabilities: International Journal of Geographical Information Systems, v. 2, n. 2, p. 143-152.

Wahba, G. 1990. Spline models for Observational data. CBMS-NSF Regional Conference Series in Applied Mathematics, Philadelphia. Soc. Ind. Appl. Maths.

Wernick, E. 1990. Zoneamento magmático regional dos granitóides brasilianos no sudeste / Sul do Brasil: implicações geotectônicas. In: Congresso Brasileiro de Geologia, 36, Belém, Anais, v. 4, p. 1668-1683.

Yamamoto, J.K. 1998. A review of numerical methods for the interpolation of geological data. In: Anais da Academia Brasileira de Geociências, v. 70, n. 1, p. 91-116.

Zaccarelli, M.A. 1988. Mina de chumbo e prata de Panelas, Paraná. In: Carlos Schobbenhaus e Carlos Eduardo Silva Coelho coordenadores: Principais depósitos minerais do Brasil, $\mathrm{V}$. III: metais básicos não-ferrosos, ouro e alumínio. DNPM, Brasilia, p. 147-156.

Zuquete, L.V. 1993. Importância do mapeamento geotécnico no uso e ocupação do meio físico: fundamentos e guia para elaboração. São Carlos, 2v. Tese (Livre Docência) - Escola de Engenharia de São Carlos, Universidade de São Paulo.

Zuquete, L.V. e Nakazawa, V.A. 1998. Cartas de Geologia de Engenharia. In: Oliveira, A.M.S. e Brito, S. N. A. Geologia de Engenharia, São Paulo- ABGE, Cap. 17, p. 283-298. 